\title{
Studies of an ortho-
}

\section{Formylation Reaction and its}

Application for the Syntheses of Anti-Cancer Agents

Dissertation for the degree of Ph.D.

Øyvind W. Akselsen

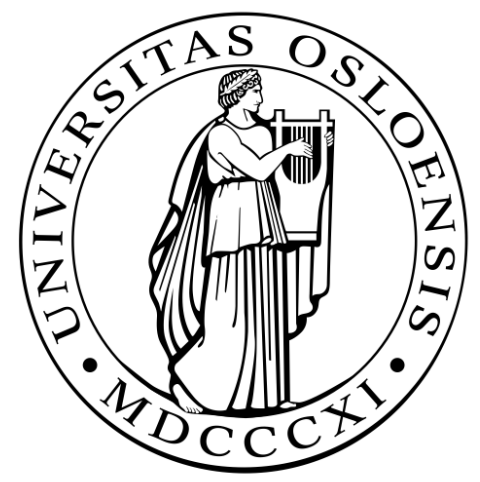

School of Pharmacy

Faculty of Mathematics and Natural Sciences UNIVERSITY OF OSLO 
(C) Øyvind W. Akselsen, 2011

Series of dissertations submitted to the

Faculty of Mathematics and Natural Sciences, University of Oslo No. 1134

ISSN 1501-7710

All rights reserved. No part of this publication may be reproduced or transmitted, in any form or by any means, without permission.

Cover: Inger Sandved Anfinsen.

Printed in Norway: AIT Oslo AS.

Produced in co-operation with Unipub.

The thesis is produced by Unipub merely in connection with the thesis defence. Kindly direct all inquiries regarding the thesis to the copyright holder or the unit which grants the doctorate. 
"Any idea that isn't completely absurd probably won't go very far."

Albert Einstein

"I don't know why the sacrifice didn't work. The science was so solid."

King Julian 


\section{Acknowledgements}

The studies presented in this thesis were performed at the Department of Pharmaceutical Chemistry, School of Pharmacy, University of Oslo, Norway, from May 2007 to August 2011, with Associate professor Trond Vidar Hansen and Professor Ragnhild E. Paulsen as supervisors. Financial support was provided by the School of Pharmacy.

I would like to thank the following persons and their groups for performing various biological assays: Vivi Ann Flørenes (Oslo University Hospital, cytotoxicity of PAC-1 derivatives), Jing-Jy Cheng (National Research Institute of Chinese Medicine, Taipei, Taiwan, cytotoxicity, tubulin inhibition and antivascular assays), Mona Gaarder and Gulzeb Aziz (School of Pharmacy, University of Oslo, cytotoxicity and caspases assays). I would also like to thank Professor Maurizio Botta for allowing me to perform molecular modelling studies in his group at the university of Siena. I am very thankful for the financial support received from Norsk Farmasøytisk Selskap, MolecularLifeScience@UiO, Ella and Robert Wenzins legat and COST CM0602 for my sojourn in Italy.

Trond, you deserve the biggest thanks for accepting me into your research group and all the aid and guidance you have given. Your enthusiasm for organic chemistry is contagious and I am in awe over your depth of knowledge on the subject. It has been inspiring working with you. Thank you.

An earnest thanks goes to Ragnhild for always having an open door and for you guidance and fruitful discussions. I would like to express great gratitude to professor emeritus Lars Skattebøl, post. doc. Anders Vik and post. Doc. Jens M. J. Nolsøe for proofreading my thesis.

I would like to thank all the members of the medicinal chemistry group, present and past, for a pleasant social and working environment.

Particularly I would like to thank Alexander, Calin, Hany, Kristin and Øyvind; you guys are my Wailing Wall and source for academic as well as personal discussions.

To my close family, mom, dad, Heidi, Ekke and Timon, I am ever grateful for your support.

Lastly, I thank the love of my life Ia for your support, unconditional love and always impatiently expecting me home. Not to be forgotten; Hermine for being soft and cuddly. 


\section{Abstract}

Recently caspases have received much attention as potential drug targets in the treatment of cancer. Procaspase-3, the executioner of apoptosis, was found to be in elevated concentrations in cancer cells. Procaspase activating compound 1, PAC-1, induced cell death through activation of caspases in a dose dependent manner in cancer cell lines. This prompted us to synthesize 16 PAC-1 analogues which were tested for their cytotoxic properties in seven cancer cell lines. Two compounds, 128 and 130, were equally cytotoxic as PAC-1 in the PC12 cell line. PAC-1 was investigated for its toxicity in non-dividing cells; chicken granular neurons, and was established as a potential neurotoxin.

The ortho-formylation reaction employing the $\mathrm{MgCl}_{2} / \mathrm{Et}_{3} \mathrm{~N}$ base system has been well established as a versatile and environmental benign method. This base system have been employed in the syntheses of salicylaldehydes, one-pot procedures and total synthesis of natural products. The original ortho-formylation method article by Skattebøl and Hofsløkken has close to 100 citations. We have explored the reaction conditions on mono-protected resorcinols and estrogens. In both compound classes, good to high yields were obtained, as well as regioselectivity. The orthoformylation of estradiol was used as a key step in the preparation of the anti-cancer agent 2methoxyestradiol.

The phosphate prodrugs of combretastatin A-1 and A-4 are currently in human clinical trials for their anti-cancer properties. Even though the solubility problems the combretastatins first faced have been solved now, there is still an issue with the isomerization of the cis-olefinic bridge to the inactive trans-isomers of the combretastatins. Our laboratory has successfully replaced the bridge with the heterocyclic moiety 1,2,3-triazole to produce cis-restricted analogues of CA-1. The analogues were subjected to cytotoxicity testing against four cancer cell lines and evaluated for their anti-angiogenetic properties. The most cytotoxic triazoles were also tested for their ability to inhibit tubulin polymerization. Compound 180 showed equal potency as CA-1 (19) in all the cell lines and was equally active as a inhibitor of tubulin polymerization and angiogenesis. These activities are most likely, at least in part, due to binding to the colchicine binding site of $\alpha, \beta$-tubulin, as supported by molecular modeling studies. 


\section{Graphical abstract}

Procaspase-activating compound 1 induces a caspase-3-dependent cell death in cerebellar granule neurons<smiles>C=CCc1cccc(/C=N/NC(=O)CN2CCN(Cc3ccccc3)CC2)c1O</smiles>

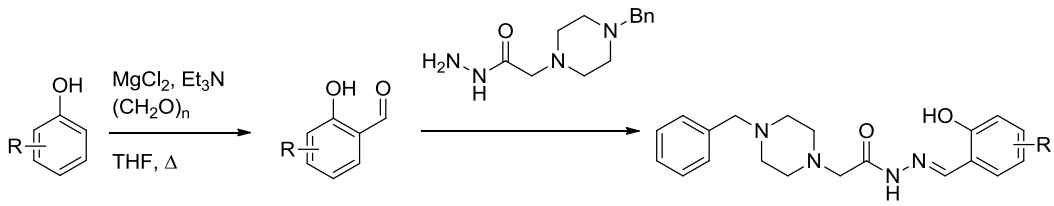

ortho-Formylation of oxygenated phenols

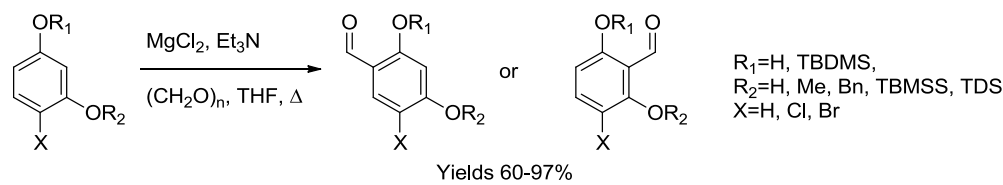

ortho-Formylation of estrogens. Synthesis of the anti-cancer agent 2-methoxyestradiol

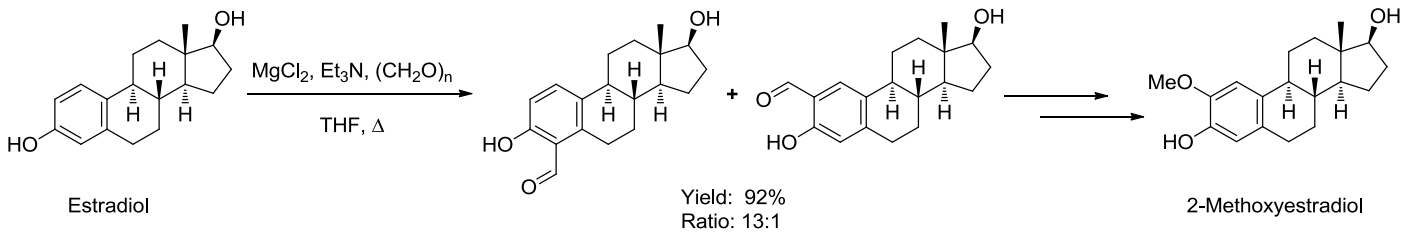

Synthesis, biological evaluation and molecular modelling of 1,2,3-triazole analogues of combretastatin A-1<smiles>COc1cc(/C=C\c2ccc(OC)c(O)c2O)cc(OC)c1O</smiles><smiles>COc1cc(Br)c(Br)c(-c2cnnn2-c2cc(OC)c(OC)c(OC)c2)c1</smiles>
Tubulin inhibition $\left(\mathrm{IC}_{50}\right.$-values in $\left.\mu \mathrm{M}\right)$ : CA-1: $\quad 3.5$ $\mathrm{R}_{1}=\mathrm{OH}: \quad 10.1$ $\mathrm{R}_{1}=\mathrm{NH}_{2}: 5.2$ Combretastatin A-1 (CA-1) 


\section{Abbreviations}

2ME2

$\mathrm{ACN}$

Ac-DEVD-cmk

Apaf-1

ATC

ATP

BBB

Boc-D-fmk

C. caffrum

CA-n

cLogP

CNS

CuAAC

$\mathrm{D}_{3} \mathrm{~A}$

DAMA-colchicine

DBU

DCM

DDQ

DIPEA

DISC

DMAP

DMF

DMP
2-Methoxyestradiol

Acetonitrile

Caspase-3 inhibitor (chloromethylketon)

Apoptotic protease activating factor 1

Anatomical Therapeutic Chemical

Adenosine triphosphate

Blood-brain barrier

Caspase Inhibitor (fluoromethylketone)

Combretum caffrum

Combretastain A-n n=number

Calculated $\log \mathrm{P}$

Central nerve system

Copper catalysed azide-alkyne cycloaddition

Three aspartic residues replaced with three alanine

$N$-deacetyl- $N$-(2-mercaptoacetyl)-colchicine

Diazabicyclo [5.4.0] undec-7-ene

Dichlormethane

2,3-Dichloro-5,6-dicyano-benzoquinone

Diispropylethylamine

Death-inducing signal complex

4-Dimethylaminopyridine

$\mathrm{N}, \mathrm{N}$-dimethylformamide

2,2-Dimethoxypropane 


\begin{tabular}{|c|c|}
\hline $\mathrm{EC}_{50}$ & Concentration that induces $50 \%$ activation of a given biological process \\
\hline $\mathrm{IC}_{50}$ & Concentration that inhibits $50 \%$ of a given biological process \\
\hline LIDAKOR & Potassium 1,1-dimethylpropoxide, $n$-BuLi and diisopropylamine \\
\hline MBA & Microtubule binding agents \\
\hline$m$-CPBA & meta-Chloroperoxybenzoic acid \\
\hline MOM & Methoxymethyl \\
\hline MTT & 3-(4,5-Dimethylthiazol-2-yl)-2,5-diphenyl tetrazolium bromide \\
\hline NBS & $N$-Bromosuccinimide \\
\hline$n$-BuLi & $n$-Butyl lithium \\
\hline PAC-1 & Procaspase activating compound-1 \\
\hline pCasp-3 & Procaspase- 3 \\
\hline RB3-SLD & RB3 protein stathmin-like domain \\
\hline SAR & Structure activity relationship \\
\hline s-BuLi & sec-Butyl lithium \\
\hline TBAF & tetra-Butylammonium fluoride \\
\hline TBCO & 2,4,4,6-Tetrabromocyclohexa-2,5-dienone \\
\hline TBDMS & tert-Butyldimethylsilyl \\
\hline TES & Triethylsilyl \\
\hline THF & Tetrahydrofuran \\
\hline TMP & 3,4,5-Trimethoxyphenyl \\
\hline TMS & Trimethylsilyl \\
\hline TPEN & $N, N, N^{\prime}, N$-Tetrakis(2-pyridylmethyl) ethylenediamine \\
\hline VDA & Vascular disrupting agent \\
\hline
\end{tabular}




\section{Table of Contents}

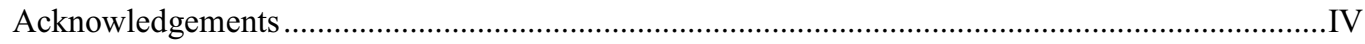

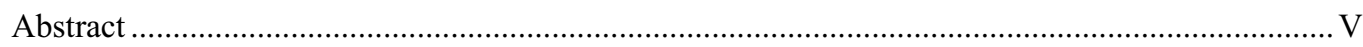

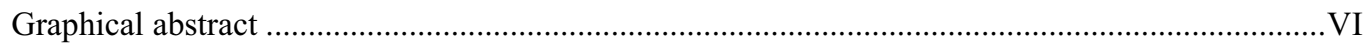

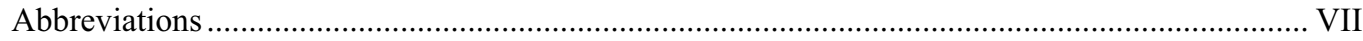

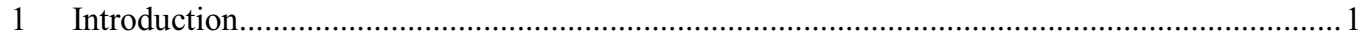

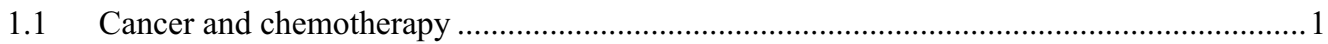

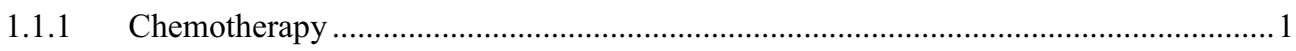

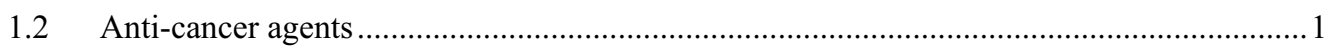

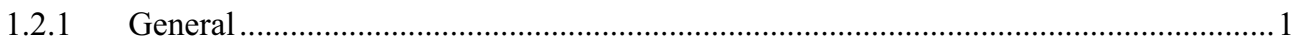

1.2.2 Antineoplastic agents and their biological mechanism .............................................2

1.3 Procaspase-3 and caspase-3 activating compounds .................................................... 3

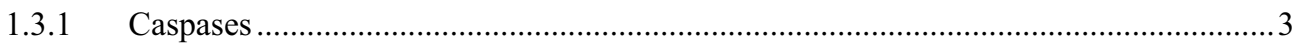

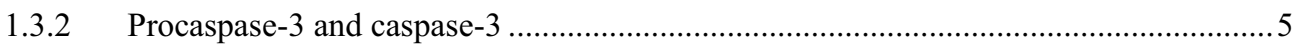

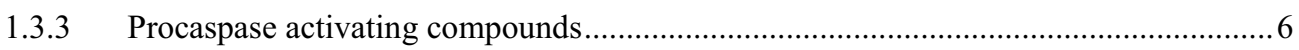

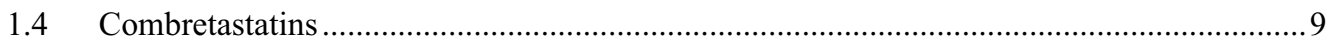

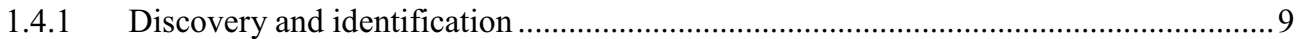

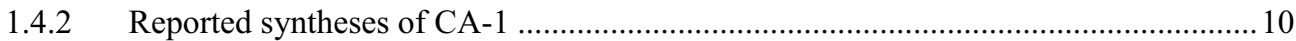

1.4.3 Biological activities of CA-1 and its corresponding prodrug .................................... 12

1.4.4 Analogues of combretastatin A-1 .......................................................................... 13

1.4.5 Summary of structure activity relationship for CA-1 analogues ................................ 17

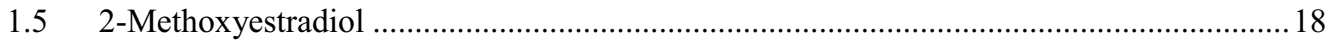

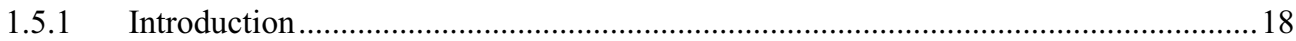

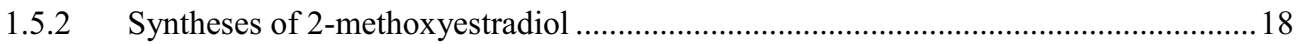

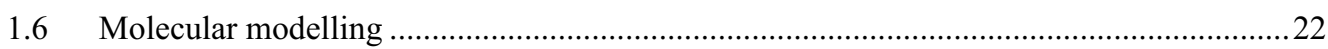

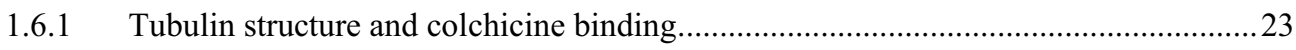

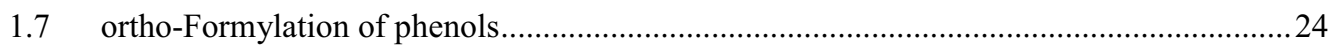

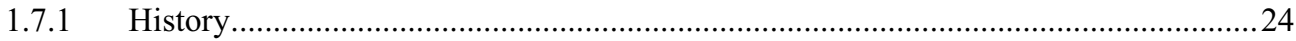

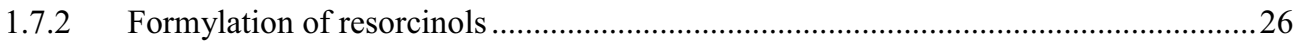

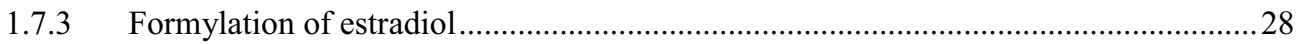

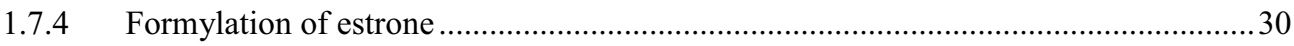




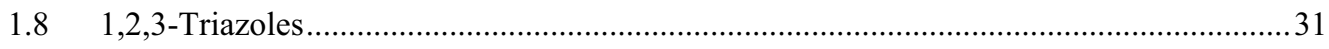

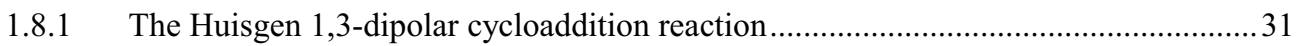

1.8.2 Selective synthesis of 1,4-disubstituted-1,2,3-triazoles .............................................. 32

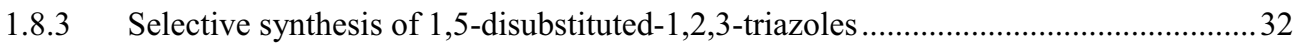

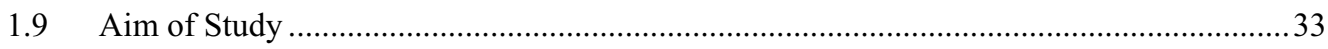

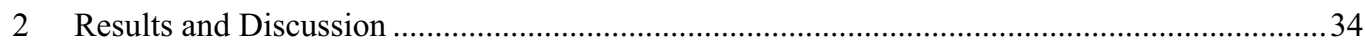

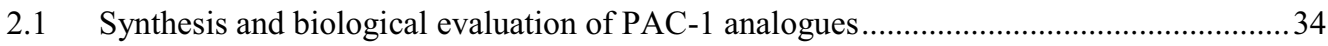

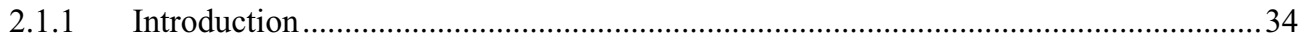

2.1.2 Synthesis and biological activities of PAC-1 derivatives ........................................... 35

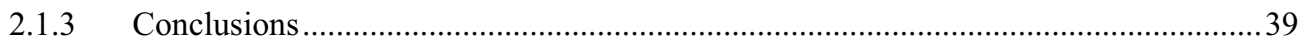

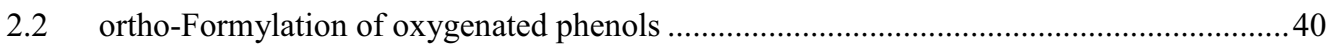

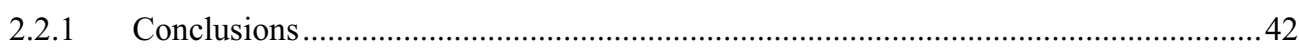

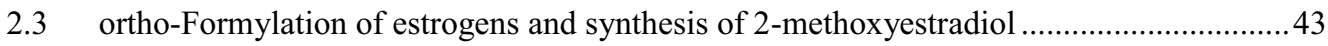

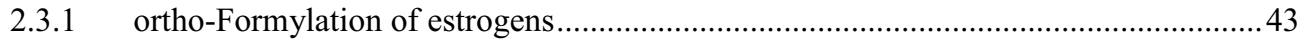

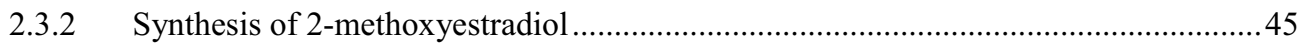

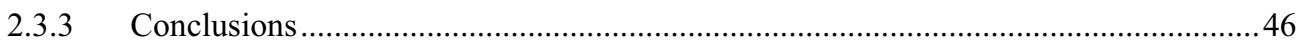

2.4 Synthesis and biological evaluation of combretastatin A-1 analogues ............................. 46

2.4.1 Synthesis of 1,4- and 1,5-disubstituted 1,2,3-triazole analogues of CA-1 ..................47

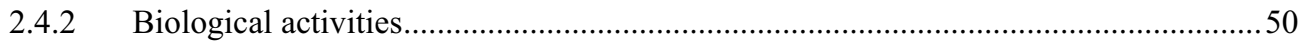

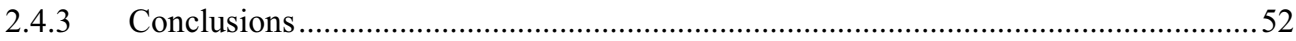

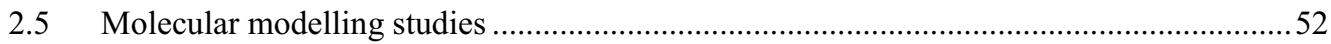

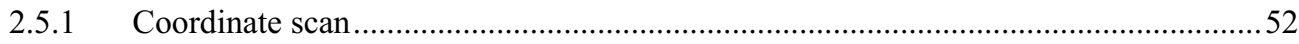

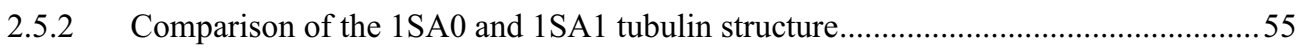

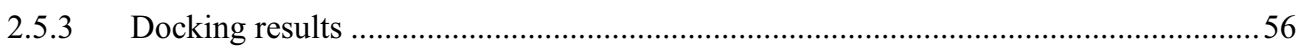

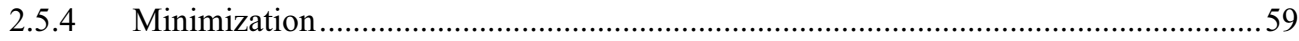

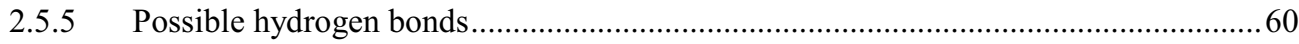

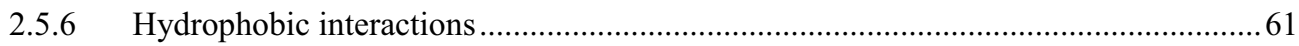

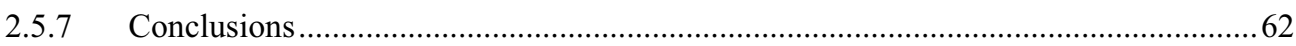

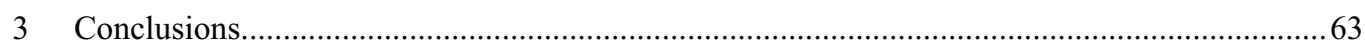

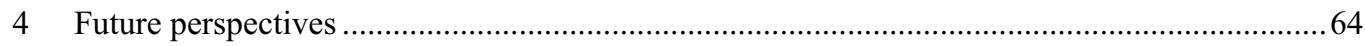

$5 \quad$ Appendix

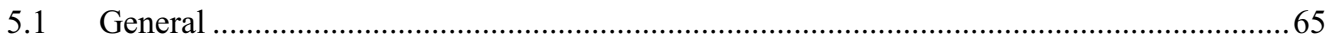

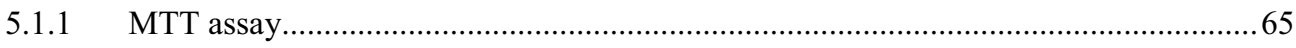

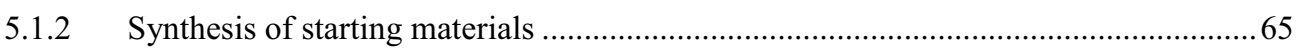




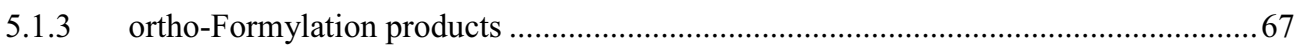

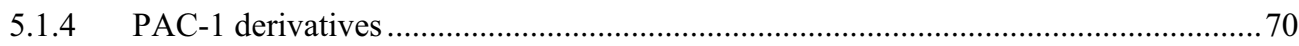

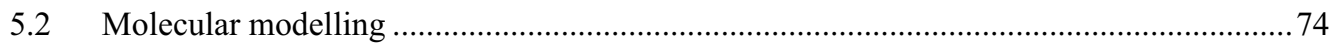

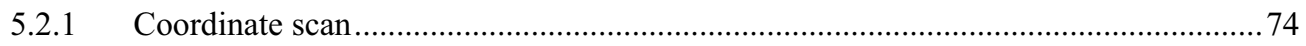

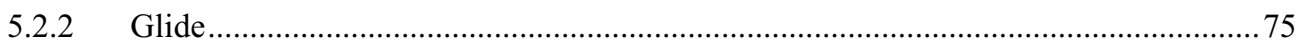

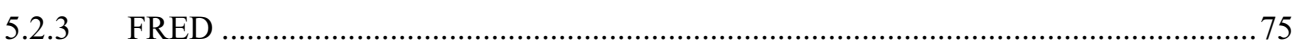

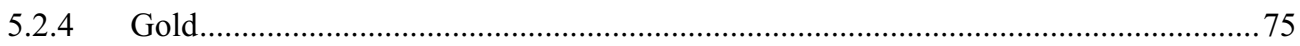

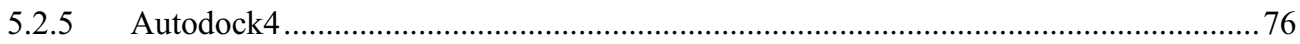

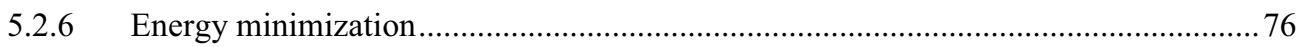

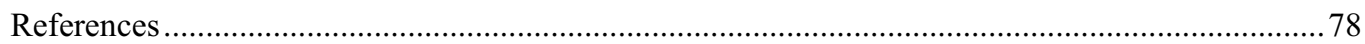

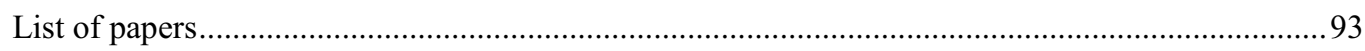




\section{Introduction}

\subsection{Cancer and chemotherapy}

Cancer is a generic term for a large group of diseases that can affect any part of the body. One defining feature of cancer is the uncontrollable growth of abnormal cells, which can then invade adjoining parts of the body and spread to other organs through the blood and lymph system. Cancer is a leading cause of death worldwide causing 7.6 million deaths in 2008 and it is estimated a $45 \%$ increase to the year 2030, and will cause over 11 million deaths. ${ }^{1}$

\subsubsection{Chemotherapy}

Depending on the manifestation of the cancer, the first line of treatments are surgical intervention, radio- and chemotherapy, but also included is psychosocial support. Despite the advances in pharmaceuticals, chemotherapy is still inadequate in treatment of various forms of cancer, and treatments have yet to obtain total remission in all forms of cancer. Classical anti-cancer agents focus on achieving increased tumour cytotoxicity based on the different proliferating activity between normal and malignant neoplastic cells. Achieving selectivity has been the Achilles heel of conventional chemotherapeutics and the consequence is embodied in the harsh side-effects observed. Recently, studies that specifically target the genes, proteins, receptors and molecular pathways that regulate the growth and survival of tumours have gained attention. ${ }^{2}$ Anti-cancer drug design and development has been inspired by these recent discoveries of potential drug targets. Consequently the search for magic bullets that improves the efficacy and diminishes the side effects of cancer therapy continues.

\subsection{Anti-cancer agents}

\subsubsection{General}

Though cytotoxic compounds have been present in plant derived traditional medicine for thousands of years, the first study and identification of a cytotoxic compound was performed in the laboratory of Paul Ehrlich. Ehrlich received the Nobel price in physiology/medicine in $1908 .{ }^{3,4}$ He first used the term chemotherapeutic agents and coined the expression "magic bullet" in regards for the strived for quality of a potential drug. The term implies that the compound will only affect a predefined target and nothing else.

Today, 100 years hence, there are numerous antineoplastic agents used in clinic and in clinical trials. 
Even now there are numerous potential magic bullets being synthesized in round bottomed flasks around the world. Science is still a long way short of understanding all the underlying mechanisms in the body by which the therapeutic agents work, but every bit and piece of knowledge is puzzled together and paving the way towards "the magic bullet".

\subsubsection{Antineoplastic agents and their biological mechanism}

Antineoplastic agents have been divided into categories according to their mechanism of action or structural similarities. According to the anatomical therapeutic chemical (ATC) register they are divided into five groups L01A-D and X corresponding to alkylating agents, antimetabolites, plant alkaloids and other natural products, cytotoxic antibiotics and other antineoplastic agents (Figure $1)^{5}$

Alkylation agents

Plant alkaloids

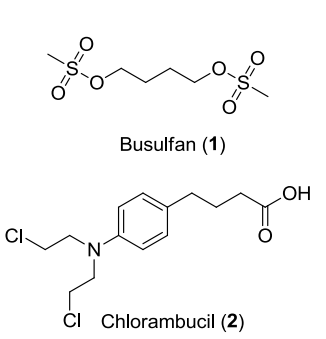

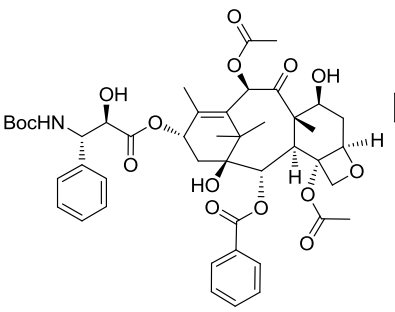

Docitaxel (9)

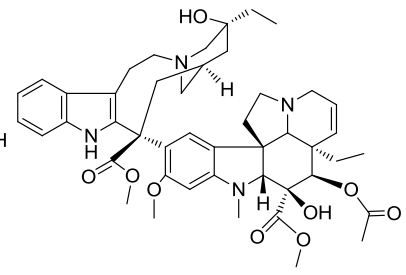

Vinblastine (10)

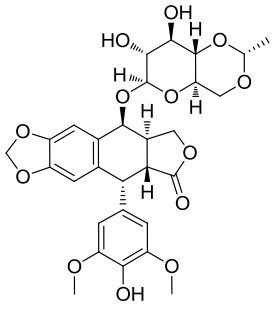

Etoposide (11)

\section{Antimetabolites}

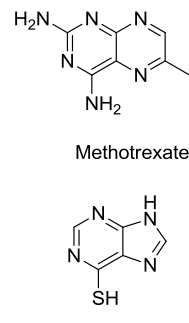

Mercaptopurine (4)

\section{Cytotoxic antibiotics}

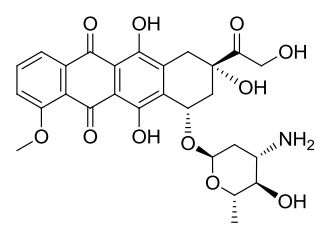

Doxorubicin (6)

\section{Other antineoplastic agents}

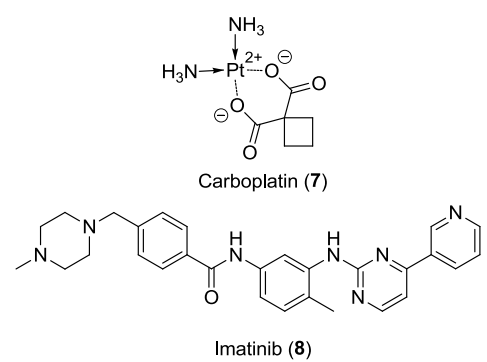

Figure 1 Selected antineoplastic agents from the ATC register.

Alkylating agents, such as $\mathbf{1}$ and 2, react covalently with the guanine base of DNA, at the 7-nitrogen atom of the purine ring. This type of alkylation hinders the cell in replicating successfully. Alkylating agents are also cytotoxic to normal cells in particular cells that divide frequently. ${ }^{6}$ Antimetabolites, such as $\mathbf{3 - 5}$, are used in cancer treatment, as they interfere with biosynthesis of 
DNA and therefore cell division and the growth of tumours. The interference is caused by the inhibition of an enzyme in the biosynthetic pathway of the metabolite or from incorporation, as a false building block, into vital proteins and polynucleosides. ${ }^{6}$ The mechanisms of action of the cytotoxic antibiotics, doxorubicin (6), are not fully understood. 6 act by interchelation of DNA, crosslinking of DNA, inhibition of macromolecular biosynthesis and as DNA strandbreaker. The class of other antineoplastic agents is a diverse group of drugs that are inhibitors of type I and II topoisomerase, crosslinkers of DNA and as monoclonal antibodies. Compounds $\mathbf{7}$ and $\mathbf{8}$ are two examples. $^{5,6}$

Docitaxel (9), vinblastine (10) and podophyllotoxin block cell division by targeting microtubule function by either a stabilizing or a destabilizing mechanism. All of the compounds 9-11 are considered microtubule binding agents (MBA), and each bind to a specific binding site. The taxoid and podophyllotoxin/colchicine sites are known while scientists are still searching for the exact vinca alkaloid site. ${ }^{7,8}$ Microtubules are vital for cell division, and, without them, cell division cannot occur. ${ }^{9}$ Podophyllotoxin is used in production of two other cytostatic drugs, etoposide (11) and teniposide. The exact mechanism of action of podophyllotoxin and derivatives is not yet known, but it involves inhibiting the catalytic activity of DNA topoisomerase II and in some cases ambiguous mechanisms. ${ }^{9}$ The search for new MBAs continues and currently several compounds are under investigation as potential drug candidates. ${ }^{10}$

Studies have shown that most MBAs have antivascular effects from anti-angiogenetic or vascular disrupting activities, or both. ${ }^{11}$ Disrupting the blood supply leads to starvation of the tumour, consequently this prevents growth and induces necrosis. There are two different biological pathways that affect tumour vasculature: inhibition of angiogenesis and the formation of new vessels from pre-existing ones, and a vascular disrupting pathway that selectively destroys the already formed tumour vascular bed. ${ }^{11}$ The anti-angiogenetic approach exerts mainly a cytostatic effect, while vascular disrupting agents induce tumour necrosis and vessel collapse inside the tumour. However, induction of tumour necrosis by a single administration does not lead to tumour eradication, as a rim of viable tumour cells survives and proliferates in the periphery of the tumour. $^{11}$

\subsection{Procaspase- 3 and caspase- 3 activating compounds}

\subsubsection{Caspases}

In multicellular organisms, homeostasis is maintained through a balance between cell proliferation and cell death. Owing to its role in the elimination of virally infected and damaged cells, apoptosis 
has a central role in the prevention of diseases. Hyper or hypo activity of caspases (cysteinyl aspartate proteinases) leads to a host of pathologies, including cancer, autoimmune diseases, sepsis, immunodeficiency and neurodegenerative disorders. ${ }^{12}$ The role of caspases in cell homeostasis is more important than what one might first imagine; knockout mice without either one of the genes for caspase-3, -8 and -9 die prenatally or postnatally mostly due to defective brain development. ${ }^{12} \mathrm{~A}$ dysfunction in the apoptotic cascade might be one of the factors that lead to aberrant proliferation of tumour cells as the cell do not self eliminate when proapoptotic signals are triggered.

The caspases are a family of cysteine proteases, enzymes that cleave their substrates following an aspartate residue. There are 15 identified mammalian caspases and all their biological roles are yet to be fully elucidated. ${ }^{12-17}$ They are synthesized as inactive zymogens consisting of a prodomain, a large p20 and a small p10 subunit. The size of the prodomain varies, and can be used to divide the caspases into two different main groups, the initiator caspases (caspase-1, -2, -4, -5 and 8-12) and the effector caspases (caspase-3, -6 and -7). The caspases play a central role in the initiation and execution phases of apoptosis. ${ }^{12}$ Upon activation, these enzymes cleave specific substrates and thereby mediate many of the typical biochemical and morphological changes in apoptotic cells, such as cell shrinkage, chromatin condensation, DNA fragmentation and plasma membrane blebbing. ${ }^{12-16}$ Activation of the zymogens by proteolytic cleavage separates the large and small subunits and removes the prodomain. The active caspases consist of a homodimer, with each monomer of a large and a small subunit (Figure 2). ${ }^{12}$
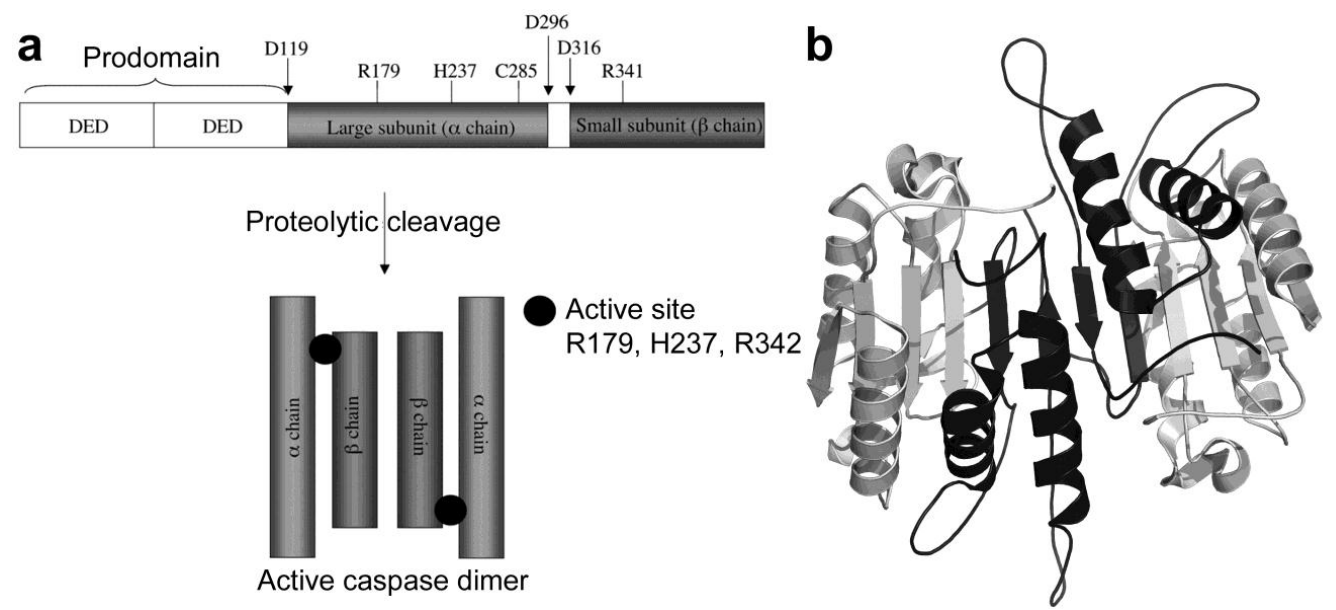

Figure 2 The structure and activation of caspases. (a) The prodomain is cleaved from the caspase and the monomer forms the active homodimer with a second cleaved caspase. Adapted from reference. ${ }^{14}$ (b) X-ray structure of active caspases-7 (pdb: 1K88), ${ }^{18}$ p10 black and p20 grey. 
There are two general modes of caspase activation, the extrinsic (death receptor pathway) and intrinsic (internally initiated by damage and stress) (Figure 3). The extrinsic pathway is activated by extracellular stimulus that is transmitted to the cytosol by transmembrane death receptors that belong to the family of tumour necrosis factor receptors. Recruitment of procaspase- 8 and -10 as well as other ligands at this receptor leads to the formation of a death-inducing signalling complex (DISC) that triggers maturation of both initiators. Ultimately, procaspase-3 ( $p$ Casp-3) and procaspase- 7 are activated by the mature caspases- 8 and $-10 .{ }^{17}$ The intrinsic pathway can be triggered by stimuli such as DNA damage and cytotoxic drugs or UV-radiation. Different damages or stress signals promote, via protein messengers, the mitochondria to release cytochrome $c$. Cytosolic cytochrome $c$, apoptotic protease activating factor 1 (Apaf-1) and the cofactor dATP/ATP then form a multimeric protein complex called the apoptosome. Procaspase-9, which is activated through an apoptosome-induced conformational change, further processes the downstream caspases, such as $p$ Casp-3 and procaspase-7, to carry out the eventual execution of apoptosis. ${ }^{17}$

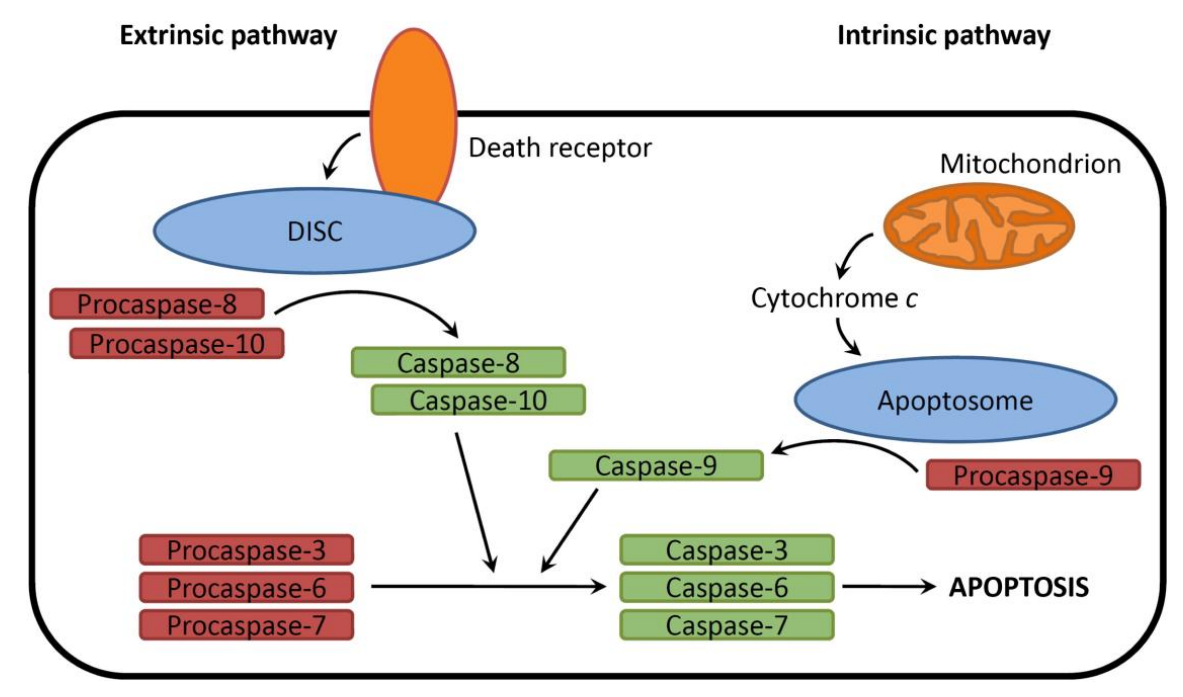

Figure 3 The biological activation cascade of $p$ Casp-3. Adopted from reference. ${ }^{19}$

\subsubsection{Procaspase-3 and caspase-3}

pCasp-3 together with procaspase- 6 and -7 are the effector caspases, also known as executioner caspases, as they initiate cellular suicide apoptosis. $p$ Casp-3 is activated by either caspase- $8,-9$ or 10 upstream in the apoptotic cascade as well as autocatalytic cleavage. This cleavage is also sensitive to acidification as its dormancy is guarded by an triaspartic acid "safety catch". ${ }^{20}$ Furthermore, zinc plays an important role in apoptosis as a natural inhibitor of caspase-3 activity. ${ }^{21-}$ ${ }^{23} \mathrm{X}$-linked inhibitor of apoptosis (XIAP) is an endogenous inhibitor that binds reversibly to 
caspase- 3 and $-7 .{ }^{24,25}$ Numerous small molecules and peptides that are inhibitors of caspases- 3 have been synthesized. ${ }^{26-31}$

Cells from certain types of cancerous tissues have elevated concentrations of $p$ Casp-3. A study of primary isolates from 20 individuals with colon cancer, showed that on average, $p$ Casp-3 is elevated six-fold in such isolates relative to adjacent noncancerous tissue. ${ }^{20}$ In addition, $p$ Casp-3 concentrations are elevated in certain neuroblastomas, ${ }^{32}$ lymphomas, ${ }^{33}$ leukemias, ${ }^{34}$ melanomas, ${ }^{35}$ and liver cancers. ${ }^{36}$ A systematic evaluation of $p$ Casp-3 concentrations revealed that particular lung, melanoma, renal and breast cancers show greatly enhanced concentrations of $p$ Casp- 3 in the panel of 60 cell lines used by the National Cancer Institute. ${ }^{37}$

\subsubsection{Procaspase activating compounds}

In October 2006 Hergenrother and co-workers published an article that claimed to have identified and synthesized the first direct procaspase activating compound-1 (Figure 4, PAC-1, 12). Based on the observations that cancer cells have elevated $p$ Casp-3 concentration levels, they envisioned a personalized anti-cancer therapy, based on the direct activation of $p$ Casp $-3 .{ }^{38}$ With the aid of high throughput screening, approximately 20500 structurally diverse small molecules were evaluated for pCasp-3 activation in vitro.
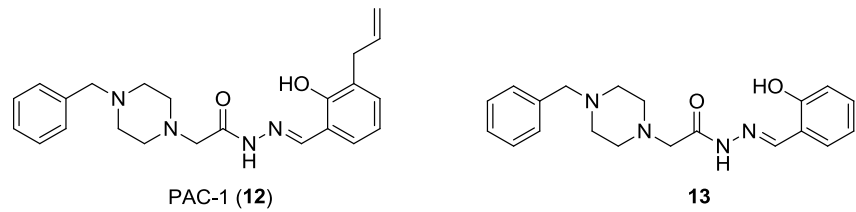

13

Figure 4 Procaspase activating compound 1 (PAC-1) and a second active derivative.

Only one of the compounds screened activated $p$ Casp-3 in a dose dependent manner with an $\mathrm{EC}_{50}$ value of $0.22 \mu \mathrm{M}$. Compound 13, which was prepared after the discovery of PAC-1 (12), was half as active with an $\mathrm{EC}_{50}=0.43 \mu \mathrm{M}$. PAC-1 (12) was less active against $p$ Casp-3 safety catch mutants where the three aspartic acid residues were replaced with alanine $\left(D_{3} A\right)$. The researchers proposed that PAC-1 (12) had the ability to donate protons to the triaspartic acids at physiological $\mathrm{pH}$ and this was the source of its activity. The experiments conducted by the authors verified a correlation between relative $p$ Casp- 3 concentration and $\mathrm{IC}_{50}$ values in 13 cancer cell lines. The cells containing the highest $p$ Casp- 3 concentration had the lowest $\mathrm{IC}_{50}$ value and vice versa. Finally, compound 12 was effective in three distinct mouse models of cancer (one renal and two lung), including two in which PAC-1 (12) was administered orally. ${ }^{38}$ The direct activation of $p$ Casp-3 was disputed by 
Denault and co-workers since they did not observe cleavage of $p$ Casp-3 to the active caspase- 3 by compound 12. ${ }^{39,40}$

Peter Kovacic recognized that PAC-1 (12) possessed a chelating site for metal binding closely related to salicylaldehyde semicarbazones. ${ }^{41}$ These moieties are known to be avid chelators, as seen in structure 14 (Figure 5). ${ }^{42,43}$ Zinc has been shown to be an important regulator of apoptosis, and depletion of cellular zinc by chelation with the compound $N, N, N^{\prime}, N$-tetrakis(2-pyridylmethyl) ethylenediamine (TPEN, 15) resulted in activation of caspases and apoptotic cell death. ${ }^{21,22,44,45}$

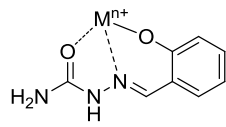

14

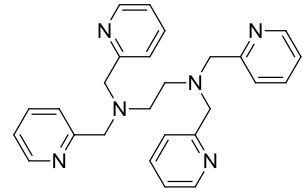

TPEN (15)

Figure 5 A salicylaldehyde semicarbazone chelating a metal ion $\left(\mathrm{M}^{\mathrm{n}+}\right)$ and the structure of TPEN.

Hergenrother and co-workers confirmed the assumption made by Kovacic when they published an article describing that PAC-1 (12) was capable of chelating zinc(II) with a $\mathrm{K}_{\mathrm{d}}$ of $42 \mathrm{nM}$. The authors concluded that PAC-1 (12) activated $p$ Casp-3 and caspase-3 in a dose dependent manner because of zinc chelation. Caspase-3 activity was also inhibited by copper(II), cobalt(II), iron(II) ions in substoichiometric or stoichiometric quantities, but other ions such as manganese(II), iron(III) and magnesium(II) had little impact on caspase-3 activity. ${ }^{46}$ A structure activity relationship (SAR) study was undertaken and derivatives of $\mathbf{1 2}$ were evaluated for cytotoxic activity against U937 cells, caspase-3 activation and zinc binding $\left(\mathrm{K}_{\mathrm{d}}\right) .{ }^{47}$ Clear trends were thus apparent from the SAR data: (1) PAC-1 derivatives that are unable to bind zinc do not activate caspase-3 in vitro, and do not appreciably induce death in U-937 cells in culture. This information suggests that the zinc binding capacity of PAC-1 (12) is important for its cell death-inducing properties. (2) The ortho-hydroxy $N$ acylhydrazone motif is critical for zinc binding. (3) Virtually all compounds that bind zinc activate caspase- 3 in vitro and induce death in U-937 cells in culture. ${ }^{47}$

Methods have been developed for the characterization of the in vivo and in vitro metabolic profile of PAC-1 (12) and for quantification in rat plasma using HPLC and MS. ${ }^{48,49}$ The same research group isolated and characterized the degradation products of $12 .{ }^{50} \mathrm{In}$ an investigation of the pharmacokinetic profile as well as a dosing regime in healthy dogs, PAC-1 (12) was found to have the properties of a potential anti-cancer drug. Hematologic and non-hematologic tolerability of 48hour PAC-1 (12) treatment was within reference values from day 0 to 21 . This treatment regimen was well tolerated in a large mammalian model (dog) which closely mimics the body size, 
physiology, and metabolism of humans. ${ }^{51}$ Despite being apparently well tolerated in dogs, compound 12 was established as neurotoxic when injected via the tail vain of C57/BL6 mice. PAC1 has a calculated partitioning ratio of 1.0:0.85 between the blood and the brain, suggesting that a significant amount of PAC-1 (12) may be entering the central nerve system (CNS) causing neurotoxicity. To overcome the neurotoxicity, a sulfonamide analogue of PAC-1 was designed, SPAC-1 (16) (Figure 6). Compound 16 showed similar cytotoxicity to PAC-1 (12) against several cancer cell lines, had a $\mathrm{K}_{\mathrm{d}}$ of $46 \mathrm{nM}$ for zinc chelation and a lower calculated propensity to cross the blood-brain barrier (BBB) (blood/brain ratio of 1.0:0.055). It was well tolerated in mice at a dose of $350 \mathrm{mg} / \mathrm{kg}$ and had no detectable neurotoxic effect.

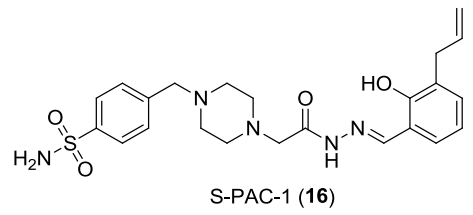

Figure 6 S-PAC-1, less probable than PAC-1 (12) to cross the blood-brain barrier.

On assessment of S-PAC-1 in dogs with lymphoma, only minor adverse events were reported which subsided within 48 hours after the end of each treatment cycle. Given the small number of patients (dogs, $\mathrm{n}=6$ ) included in this study, antitumour activity of S-PAC-1 cannot be conclusively determined. At the moment more in vivo studies are needed to establish whether S-PAC-1 (16) prospectives as an anti-cancer drug are promising.
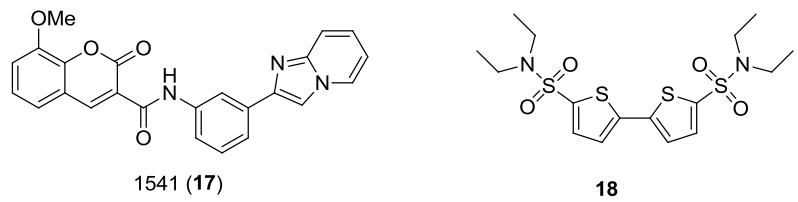

Figure 7 Casp-3 activating compounds.

Compound 17 activates $p$ Casp-3/caspase-3 by that a single molecule binds to an allosteric site near one active site of the caspase- 3 dimer as inhibitor and stabilizes an on-state conformation that promotes self-cleavage at the active site of the unoccupied subunit. At high concentrations, compound 1541 (17) can inhibit both active sites. It was cytotoxic against BT549, MDA-MB361, HEK293, HeLa, and HCC1954 cell lines. ${ }^{52}$ Based on a virtual docking protocol, Clark and coworkers proposed 15 compounds that could bind to the allosteric binding site and stabilize the onstate conformation of caspase-3. Only compound 18 showed weak activation of $p$ Casp-3 with an $\mathrm{EC}_{50}$ in the high $\mu \mathrm{M}$ range. ${ }^{53}$ None of the compounds in Figure 7 were evaluated for zinc chelation. 


\subsection{Combretastatins}

Combretastatins are a group of natural compounds that have received much attention due to their simple structure and their intriguing anti-cancer properties. ${ }^{54-58}$ Combretastatin A-1 (CA-1, 19) and A-4 (CA-4, 20) are the most studied compounds of this group; both exert potent cytotoxicity and inhibition of tubulin polymerization in vitro. The compounds $\mathbf{1 9}$ and $\mathbf{2 0}$ are hampered as drug candidates by low aqueous solubility, and CA-4 might isomerize to the less active trans-form. Their phosphate salt prodrugs 21 and 22 have been synthesized (Figure 8) and are currently in several clinical trials as anti-cancer drugs. ${ }^{56,59-61}$ Recently, the monophosphate prodrugs of CA-1 were synthesized and their cytotoxic activity were comparable to $21 .{ }^{59}$
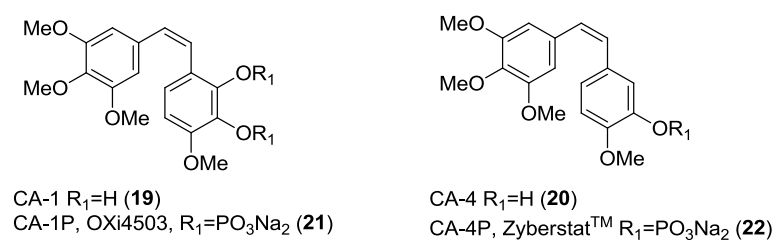

Figure 8 Combretastatins CA-1, CA-4 and their corresponding phosphate prodrugs CA-1P and CA-4P.

\subsubsection{Discovery and identification}

The combretastatins are a group of natural products isolated from the South African willow tree Combretum caffrum, a genus known for its medicinal properties in Africa and India. Cytotoxic investigation of extracts of the branches, leaves and fruit of this plant lead to the isolation and identification of combretastatin (23) by Pettit and co-workers in $1982 .{ }^{62}$ Combretastatin (23) induces astrocyte reversal and growth inhibition of the murine P388 lymphocytic leukaemia cell line. It was established as a tubulin polymerization inhibitor and to inhibit the binding of $\left[{ }^{3} \mathrm{H}\right]$ colchicine to tubulin. Moreover, it was an effective antimitotic and stimulated tubulindependent GTP hydrolysis. ${ }^{63}$ Pettit and co-workers have synthesized racemic and natural combretastatin and defined the absolute configuration of the hydroxyl group. ${ }^{64,65}$

Aside from combretastatin (23) numerous derivatives have been isolated and identified from the $C$. caffrum tree (Figure 9). 


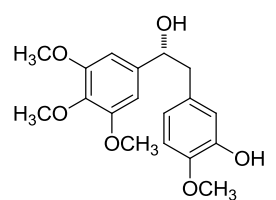

23 Combretastatin

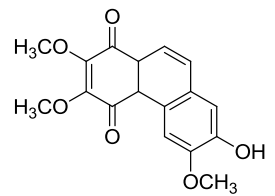

$35 \mathrm{CC}-1$

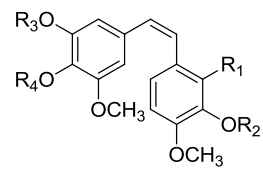

19 CA-1: $\mathrm{R}_{1}=\mathrm{OH}, \mathrm{R}_{2}=\mathrm{H}, \mathrm{R}_{3}=\mathrm{R}_{4}=\mathrm{CH}_{3}$ 20 CA-4: $\mathrm{R}_{1}=\mathrm{R}_{2}=\mathrm{H}, \mathrm{R}_{3}=\mathrm{R}_{4}=\mathrm{CH}_{3}$ 24 CA-2: $\mathrm{R}_{1}=\mathrm{R}_{2}=\mathrm{H}, \mathrm{R}_{3}=\mathrm{R}_{4}=-\mathrm{CH}_{2}$ 25 CA-3: $\mathrm{R}_{1}=\mathrm{R}_{2}=\mathrm{R}_{3}=\mathrm{H}, \mathrm{R}_{4}=\mathrm{CH}_{3}$ 26 CA-5: $\mathrm{R}_{1}=\mathrm{R}_{3}=\mathrm{H}, \mathrm{R}_{2}=\mathrm{R}_{4}=\mathrm{CH}_{3}$ 27 CA-6: trans isomer of $\mathbf{2 6}$<smiles>[R9]c1cc(CCc2ccc([R6])c([R])c2[R])cc(OC)c1[R9]</smiles>

$28 \mathrm{CB}-1: \mathrm{R}_{1}=\mathrm{OH}, \mathrm{R}_{2}=\mathrm{OH}, \mathrm{R}_{3}=\mathrm{R}_{4}=\mathrm{CH}_{3}, \mathrm{R}_{5}=\mathrm{OCH}_{3}$ 29 CB-2: $R_{1}=R_{4}=H, R_{2}=O H, R_{3}=C_{3}, R_{5}=O_{3}$ 30 CB-3: $R_{1}=R_{3}=H, R_{2}=O H, R_{4}=C_{3}, R_{5}=O_{3}$ 31 CB-4: $\mathrm{R}_{1}=\mathrm{R}_{3}=\mathrm{R}_{5}=\mathrm{H}, \mathrm{R}_{2}=\mathrm{OH}, \mathrm{R}_{4}=\mathrm{CH}_{3}$ $32 \mathrm{R}_{1}=\mathrm{R}_{5}=\mathrm{H}, \mathrm{R}_{2}=\mathrm{OH}, \mathrm{R}_{3}=\mathrm{R}_{4}=\mathrm{CH}_{3}$ $33 \mathrm{R}_{1}=\mathrm{R}_{2}=\mathrm{R}_{3}=\mathrm{R}_{5}=\mathrm{H}, \mathrm{R}_{4}=\mathrm{CH}_{3}$

$34 \mathrm{R}_{1}=\mathrm{R}_{2}=\mathrm{R}_{3}=\mathrm{H}, \mathrm{R}_{4}=\mathrm{CH}_{3}, \mathrm{R}_{5}=\mathrm{OCH}_{3}$

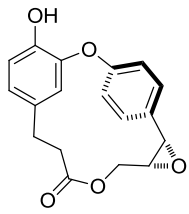

$36 \mathrm{CD}-1$

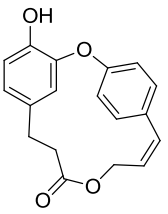

37 CD-2

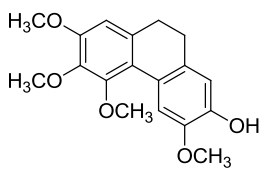

38

Figure 9 bisBenzyl derivatives isolated form C. caffrum. ${ }^{62,66-75}$

The A series are stilbenes, the B series are dihydrostilbenes, several isolated compounds (32-34) have not been given a CB number, but never the less they fit into the $\mathrm{CB}$ scaffold. The $\mathrm{C}$ series are phenantrene quinones and the D series macro cyclic lactones. Phenanthrene $\mathbf{3 8}$ has not been given any abbreviation.

Five years passed from the isolation of combretastatin before Pettit and co-workers published the second paper on the isolation of combretastatin A-1 (19) and B-1 (28) from the stem-wood extract of $C$. caffrum. Both were synthesized, characterized and found to inhibit cell growth of the murine P388 cell line as well as inhibit tubulin polymerization and $\left[{ }^{3} \mathrm{H}\right]$ colchicine binding to tubulin. ${ }^{67}$ The tubulin inhibition activity has been confirmed by others. ${ }^{76}$

From the same stem-wood extract of $C$. caffrum, combretastatin A-4, A-5 and A-6 (20, 26 and 27) were found together in a trace fraction. All three compounds were found significantly active against the murine L1210 and P388 cell lines. The growth inhibitory effects of CA-4 are comparable to CA-1, but is far more potent as a tubulin polymerization inhibitor. ${ }^{71}$

\subsubsection{Reported syntheses of CA-1}

The first synthesis of CA-1 was reported together with the isolation and structure elucidation by Pettit and co-workers (Scheme 1). ${ }^{67}$ The benzyl bromide 39 was readily prepared from the 3,4,5trimethoxybenzyl alcohol, and further reacted with triphenylphosphine to give quantitative yield of the ylide 40. The 2,3-di-tert-butyl-dimethylsilyl ether 41 was prepared from 2,3,4-trihydroxy aldehyde (42) by selectively protecting the 2,3-hydroxyl groups as the borate ester and the 4- 
hydroxyl group was selectively methylated with dimethylsulfate. After acidic deprotection of the borate ester of $\mathbf{4 3}$, disilylation was performed with TBDMSCl. The ylide was prepared with $n$-BuLi in THF and then reacted with the aldehyde 41 to give a mixture of olefins 44 and $\mathbf{4 5}$ in a total of 93\% yield in a 1:9 trans/cis mixture. Deprotection of the TBDMS ethers with TBAF produced CA1 (19), and further hydrogenation over Pd/C gave CB-1 (28).

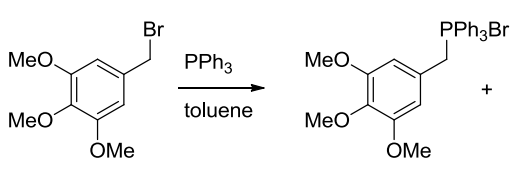

39

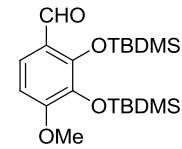

$41(>99 \%)$

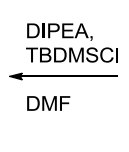

40 (99\%)
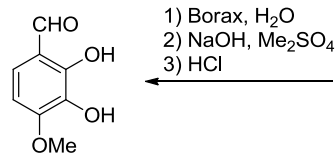

1) Borax, $\mathrm{H}_{2} \mathrm{O}$

2) $\mathrm{NaOH}, \mathrm{Me}_{2} \mathrm{SO}_{4}$ 3) $\mathrm{HCl}$

$43(72 \%)$<smiles>O=Cc1ccc(O)c(O)c1O</smiles>

42

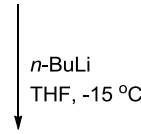<smiles>CCOc1c(OC)ccc(/C=C/c2cc(OC)c(OC)c(OC)c2)c1OCCOC</smiles>

44

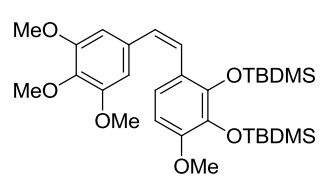

45

trans/cis 1:9 Total yield $93 \%$

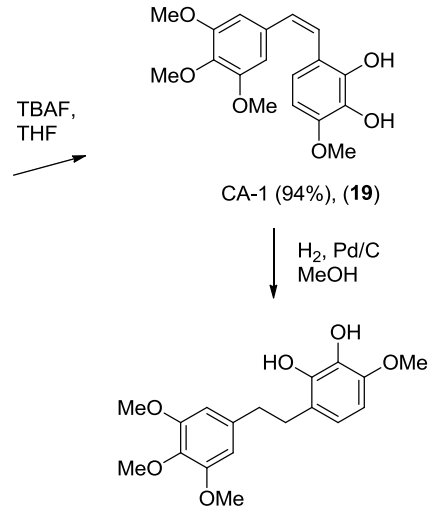

CB-1 (28)

Scheme 1 First total synthesis of CA-1 and CB-1 by Pettit and co-workers. ${ }^{67}$

The synthesis was later improved by Orsini and co-workers by employing the benzyl chloride phosphonium salt, due to the instability and difficulties with purification of the benzyl bromide phosphonium salt (40). ${ }^{76}$ Pettit and co-workers later improved two of the steps of their first synthesis (Scheme 1), compound $\mathbf{4 3}$ was synthesized by selective demethylation of 2,3,4methoxybenzaldehyde (46) with $\mathrm{BCl}_{3}$. Secondly, the removal of the TBDMS groups of CA-1 (45) was performed with $48 \% \mathrm{HBr}$ (cat.) and potassium fluoride in DMF (Scheme 2). ${ }^{77}$ 


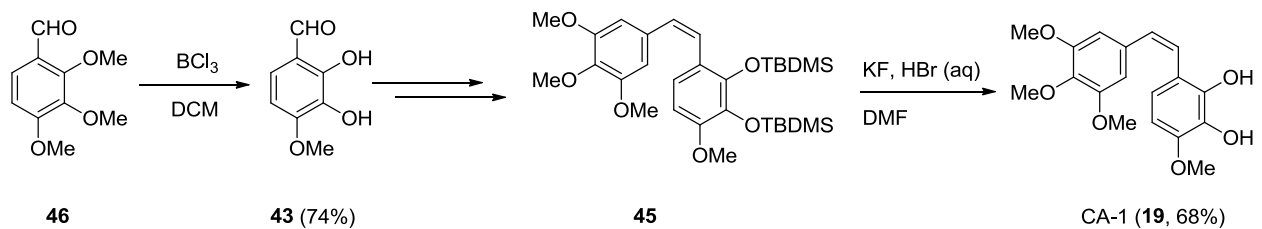

Scheme 2 Modified CA-1 synthesis reported by Pettit and co-workers.

Recently, the syntheses of ${ }^{14} \mathrm{C}$-labeled $\mathrm{CA}-1$ and its prodrug have been reported. ${ }^{78,79}$ Chemoenzymatic syntheses of CA-1 (19) and CB-1 (28) have been reported in good overall yields. $^{80}$

Also a one-pot ortho-formylation-Dakin oxidation reaction ${ }^{81}$ developed in our group, combined with a Sonogashira coupling reaction yielded, the diaryl alkyne 47 (Scheme 3). cis-Selective hydroboronation or hydrogenation with $\mathrm{Pd} / \mathrm{C}$ followed by deprotection of the MOM ethers gave CA-1 (19) and CB-1 (28) in good yields. ${ }^{82}$

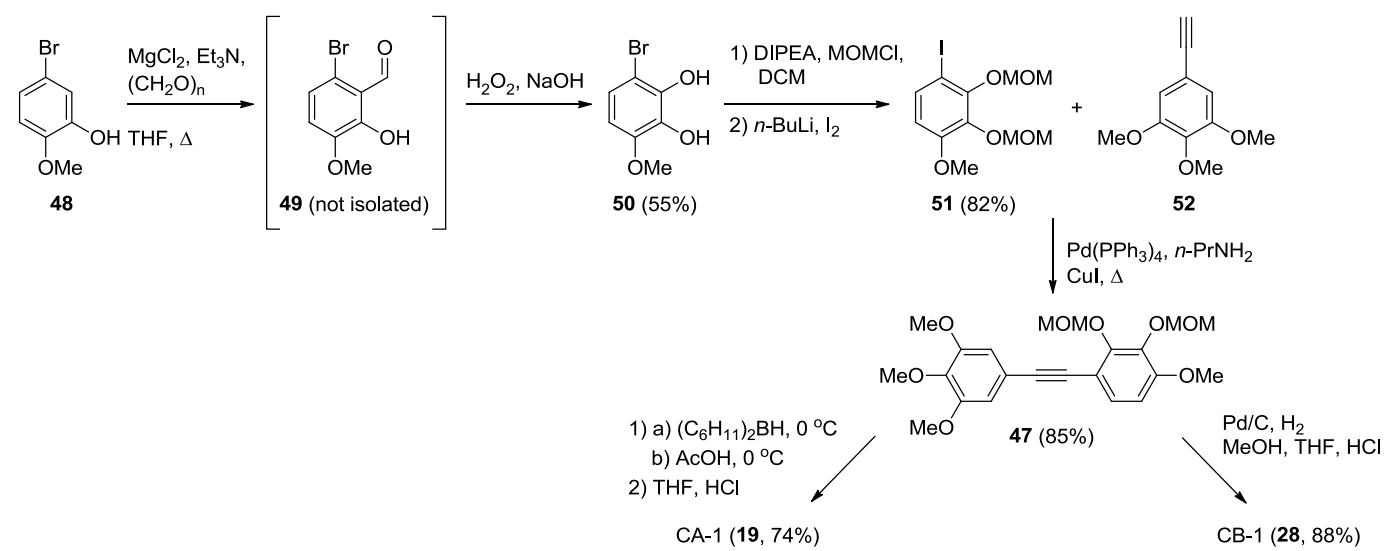

Scheme 3 One-pot ortho-formylation-Dakin oxidation syntheses of CA-1 (19) and CB-1 (28).

\subsubsection{Biological activities of CA-1 and its corresponding prodrug}

The isolation and identification of CA-1 (19) as a potent inhibitor of microtubule assembly was established in $1987 .{ }^{67} \mathbf{1 9}$ binds to or near the colchicine binding site of tubulin and was shown to inhibit the binding of $\left[{ }^{3} \mathrm{H}\right]$-colchicine to tubulin. In addition, CA-1 (19) has been reported to undergo oxidation in vitro to its ortho-quinone derivative that might bind to the thiols groups of proteins and possibly nucleic acids (Figure 10). ${ }^{83-86}$ This secondary mechanism is believed to be favourable for its in vivo activities and to be partly responsible for the slightly superior activity of 
CA-1P over CA-4P. ${ }^{87,88}$ Moreover, compound 19 can act as a VDA. ${ }^{89}$ Histologic evidence showed that the viable rim of tumour cells surviving single treatment with CA-1P were significantly smaller that with CA-4P treatment 72 hours post administration. ${ }^{88} \mathrm{CA}-1$ (19) has been found cytotoxic against numerous cancer cell lines. ${ }^{67,68,74,90,91}$ Pre-clinical evaluation indicates that CA-1P was equally potent as CA-4P at a quarter of the dose. In addition, it induced tumour growth delays and regressions were also observed when used as a single agent. ${ }^{87,88,92}$
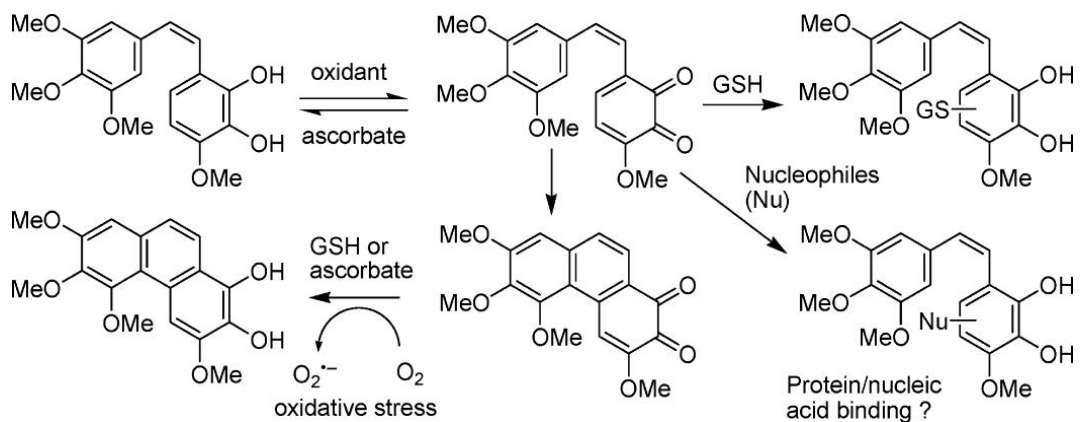

Figure 10 Structure of combretastatin A-1 (19) and the reaction pathways following oxidation of CA-1. Adopted from reference. $^{84}$

\subsubsection{Analogues of combretastatin A-1}

The combretastatins structure can be described in three parts: A-ring, B-ring and a bridge between the two.

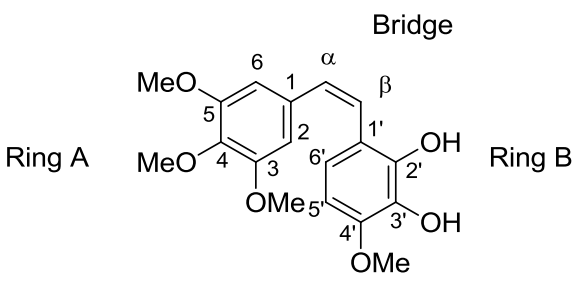

Combretastatin A-1 (19)

Figure 11 The different components of combretastatin A-1 with numbering; A-ring, bridge and B-ring.

Extensive modification of the combretastatin structure has been explored in order to understand the structure activity relationships and to discover more potent analogues. ${ }^{93-97}$ CA-1 (19) has been less studied than CA-4 (20) and fewer analogues have been synthesized compared to $\mathbf{2 0 .}$

A full review of all of the analogues of combretastatin is more suited for a book than this thesis, hence only an overview of the CA-1 (19) analogues will be given. To discriminate between 19 and other combretastatin analogues a criterion is that $\mathrm{C}-2^{\prime}$ must be substituted; the bridge must be two 
atoms; and the A- and B-ring cannot be connected by others means than the bridge. trans-Stilbenes will not be discussed as they have been shown to be inactive. ${ }^{74,98,99}$ Therefore, the modifications have been divided into the following groups: A-ring, B-ring and bridge. The two point modifications: A/B-ring, bridge/A-ring, bridge/B-ring and finally three point modifications.

\section{A-ring modifications}

Few research groups have attempted to modify the A-ring of the CA-1 (19) structure. Based on the SAR data published on CA-4, the 3,4,5-trimethoxyphenyl (TMP) moiety should be conserved as altering the substitution pattern has detrimental effect. ${ }^{68,100-102}$ Never the less some compounds have found their way through the synthetic pipeline (Figure 12).
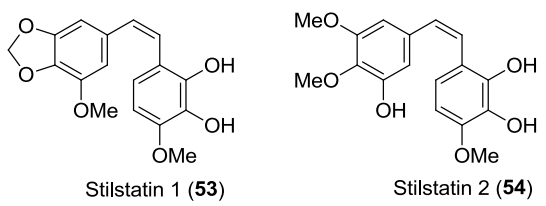

Figure 12 A-ring modified CA-1 analogues.

Stilstatin 1 (53) is a naturally isolated compound and had reduced growth inhibition of the L1210 cell line compared to CA-1 (19). Inhibition of tubulin polymerization and $\left[{ }^{3} \mathrm{H}\right]$ colchicine binding activity was retained compared 19. ${ }^{68}$ Stilstatin $2(\mathbf{5 4})$ was later synthesized by the same group, both compounds were cytotoxic evaluated and found less active than $19 .{ }^{98}$

\section{Bridge modifications}
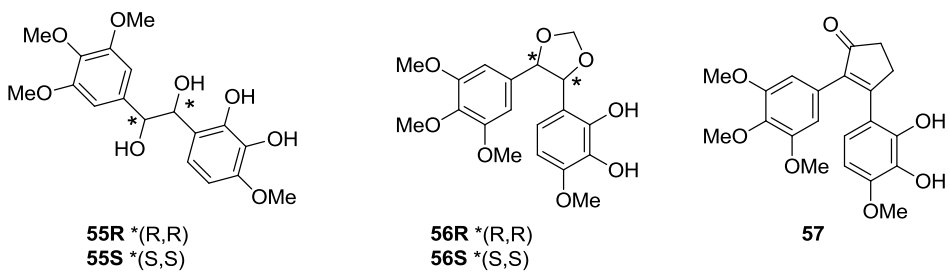

Figure 13 Bridge modified CA-1 analogues.

The diols 55S and 55R (Figure 13) were significantly less potent tubulin polymerization inhibitors than the parent compound CA-1 (19)..$^{91}$ The dioxolane 56S was a highly potent inhibitor of microtubule assembly $\left(\mathrm{IC}_{50}=0.59 \mu \mathrm{M}\right)$, twice as potent as $\mathbf{1 9}$, and inhibited the growth of P388 cell 
line with an $\mathrm{ED}_{50} \sim 1.5 \mu \mathrm{g} / \mathrm{mL}$. The enantiomer 56R inhibited microtubule assembly at a tenfold concentration of CA-1. ${ }^{103}$ Compound $\mathbf{5 7}$ had low cytotoxicity compared to the analogues evaluated by the authors. ${ }^{104}$

\section{B-ring modifications}

Modifications on the B-ring of CA-1 have been investigated extensively in comparison to the Aring. ${ }^{68,76,85,105-107}$ The dihydroxyl groups have been replaced by nitro, amine, fluoro, O-acetyl, Oglycosides and methoxy groups (Figure 14). The difluoro substituted compound $\mathbf{5 8}$ increases cell growth inhibition 16-fold compared to CA-1in the K562 cell line. ${ }^{107}$ The diamine analogue 59 inhibits microtubule assembly with an $\mathrm{IC}_{50}$ value comparable to CA-1. Pleasantly it surpassed CA-1 with 10-100 fold higher cytotoxicity against six cancer cell lines. The authors stated that $\mathbf{5 9}$ was capable of forming an ortho-diimine (60) analogous to ortho-quinone of CA-1 (19) without providing data for this mechanism. ${ }^{105}$
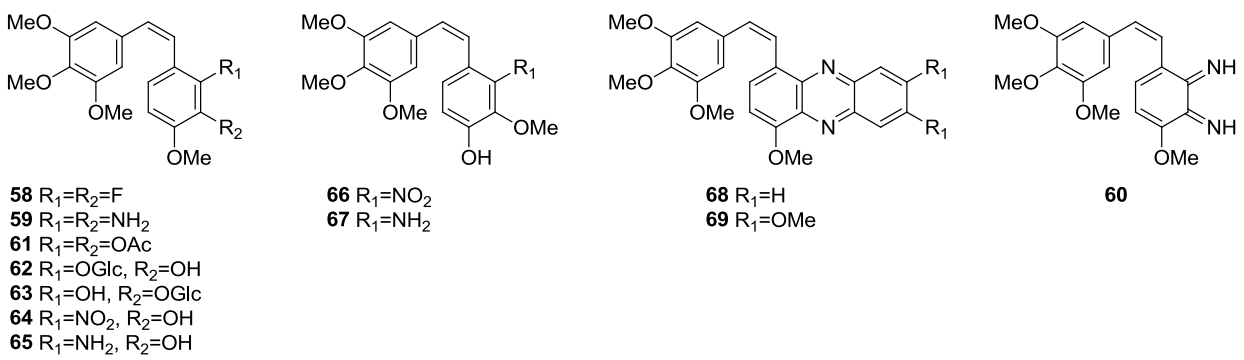

60

Figure 14 B-ring analogues of CA-1

The acetylated compound 61 was cytotoxic in the $\mathrm{L} 1210$ cell line $\left(\mathrm{IC}_{50}=0.06 \mu \mathrm{M}\right)$ but inhibition of tubulin polymerization and $\left[{ }^{3} \mathrm{H}\right]$ colchicine binding were both significantly lower than CA-1 (19). ${ }^{68}$ In general, the compounds 62 and $\mathbf{6 3}$ were significantly less cytotoxic than CA-4 (20); both were active inhibitors of microtubule assembly, but less active than $\mathbf{1 9} .^{76,108}$

Compound 64 was equally good tubulin inhibitor as CA-1 (19), but lacked cytotoxic activity. Compound $\mathbf{6 5}$ had good tubulin inhibition and cytotoxicity in the cell lines tested. ${ }^{106}$ Nitro and amine derivatives $\mathbf{6 6}$ and $\mathbf{6 7}$ were inactive as tubulin inhibitors and as cytotoxic agents. ${ }^{106}$ Phenazines 68 and 69 were found to significantly inhibit the growth of P388 cell line with a $\mathrm{ED}_{50} \sim$ $0.2 \mu \mathrm{g} / \mathrm{mL}^{85}$ 


\section{Combinations of A-ring and B-ring modifications}<smiles>[X]c1c(O)ccc(/C=C\c2cc(OC)c(OC)c(OC)c2Br)c1OC</smiles>

$70 \mathrm{X}=\mathrm{Br}$ $71 X=1$

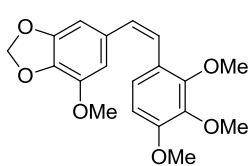

72

Figure 15 Analogues where the A- and B-rings are modified

The dibromide 70 (Figure 15) showed some activity in the ZR-75-1 breast cancer cell line, about one fifteenth as active as CA-4 (20). However, 19 was not evaluated, neither was the iodo analogue 71. ${ }^{109}$ The CA-1 analogue $\mathbf{7 2}$ was a weak inhibitor of the L1210 cell line and tubulin polymerization. ${ }^{68}$

\section{Combinations of bridge and A-ring modifications}<smiles>COc1ccc(CCc2cc(OC)c3c(c2)OCO3)c(O)c1O</smiles>

73<smiles>COc1ccc(C(=O)C2=CCCc3c2cc(OC)c(OC)c3OC)c(O)c1O</smiles>

74<smiles>COc1ccc(C(=O)C2=CCCCc3c2cc(OC)c(OC)c3OC)c(O)c1O</smiles>

75

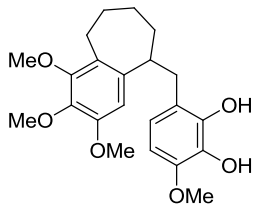

76

Figure 16 Bridge and B-ring modified CA-1analogues.

The saturated bridge analogue 73 (Figure 16) inhibited tubulin polymerization at twice the concentration of CA-1 (19), but was not able to inhibit $\left[{ }^{3} \mathrm{H}\right]$ colchicine binding to tubulin. 73 inhibited growth in the $\mathrm{L} 1210$ cell line $\left(\mathrm{IC}_{50}=8 \mu \mathrm{M}\right)$ one tenth the cytotoxic activity of $19 .{ }^{68}$ The tricyclic compound $\mathbf{7 4}$ exhibited cytotoxic activity against the cell lines tested, but was less active compared to CA-1. Compounds $\mathbf{7 4}$ and $\mathbf{7 5}$ were inactive as tubulin inhibitors. While compound 76 was not cytotoxic against the cell line tested, but inhibited microtubule polymerization at one fourth of the concentration of CA-1. ${ }^{110}$ 
Bridge and B-ring modified CA-1analogues<smiles>COc1cc(CCc2ccc(OC)c(OC)c2OC)cc(OC)c1OC</smiles>

77<smiles>COc1cc(C2=C(c3cccc(O)c3O)CCC2=O)cc(OC)c1OC</smiles>

78<smiles>COc1cc(N2C(=O)CC2c2ccc(OC)c(OC)c2OC)cc(OC)c1OC</smiles>

80<smiles></smiles>

$81 \mathrm{R}_{1}=\mathrm{Me}$ $82 \mathrm{R}_{1}=\mathrm{CH}_{2} \mathrm{OH}$ $83 \mathrm{R}_{1}=\mathrm{H}$

Three point modified CA-1 analogue<smiles>COc1ccc(C2=C(c3cc(O)ccc3O)CCC2=O)c(OC)c1OC</smiles>

79

Figure 17 Bridge and B-ring modified CA-1 analogues. Three point modified CA-1 analogue

The dihydro stilbene 77, compound 78 and 79 (Figure 17) were inactive in the assays tested. ${ }^{68,99,104}$ $\beta$-Lactam analogue 80, with two TMP moieties, was significantly less cytotoxic compared to CA-4 (20) in the MCF-7 and MDA-MB-231 cell lines. ${ }^{111}$ The indazole based analogues 81-83 were slightly more cytotoxic compared to $\mathbf{1 9}$ in the H460 cell line. Further evaluation showed that they were all cytotoxic towards PC3, HeLa and HT29 cancer cells as well. ${ }^{112}$ Only 82 inhibited tubulin polymerization in vitro with a similar $\mathrm{IC}_{50}$ value as $\mathbf{2 0}$.

\subsubsection{Summary of structure activity relationship for CA-1 analogues}

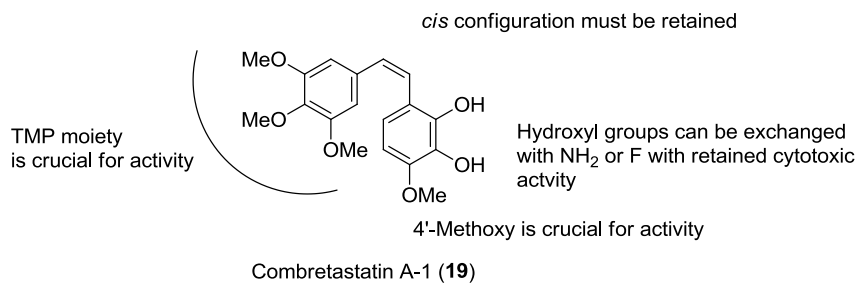

Figure 18 Summary of structure activity relationship for CA-1 analogues.

From the SAR reviewed certain trends are notable. The A-ring and the three methoxy groups should not be substituted for other groups. The cis configuration of the bridge is essential, but can be 
exchanged with a dioxolane ring. However, the stereochemistry was important. The 4'-methoxy group is important for activity, but the hydroxyl groups can be substituted for amino groups or fluorine atoms with improved cytotoxic activity. These SAR trends are similar to what has been reported for $\mathrm{CA}-4 .^{93,113}$

\subsection{2-Methoxyestradiol}

\subsubsection{Introduction}

The discovery of sex-hormones and their biological activities have played an important part in drug discovery, and both agonists and antagonists of sex-hormones are used in drug therapy. ${ }^{114} 2$ Methoxyestradiol (Figure 19, 2ME2, 85) was believed to be an inactive metabolite of estradiol, until the tubulin polymerization inhibition was reported in 1989. The anti-angiogenetic activity was first reported five years later. ${ }^{115-118}$
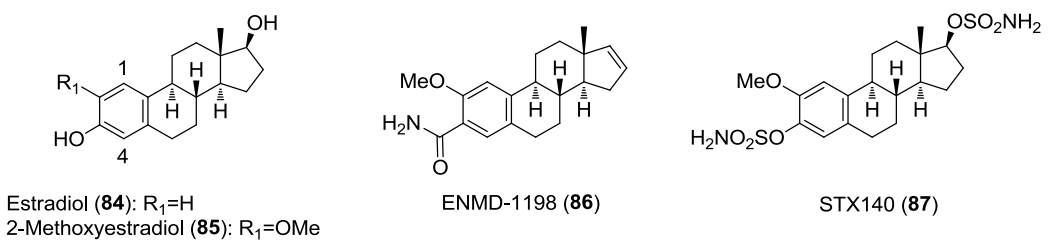

Figure 19 Estradiol, 2-Methoxyestradiol and two analogues, ENMD-1198 and STX140, which are currently in clinical trials.

2ME2 has been established as a cytotoxic compound with several modes of action, and has shown promising preclinical results as an anti-cancer agent. Several clinical trials in various forms of cancer have been conducted. ${ }^{119}$ Furthermore, compounds 86 and 87, developed from 2ME2, have advanced to clinical trials (Figure 19). ${ }^{120}$

\subsubsection{Syntheses of 2-methoxyestradiol}

An efficient synthesis of 2ME2 (85) has been long sought for since the discovery of its biological activities. In 1958 Jack Fishman (Figure 20, path a) reported the first synthesis of $\mathbf{8 5}$ from estradiol (84). 

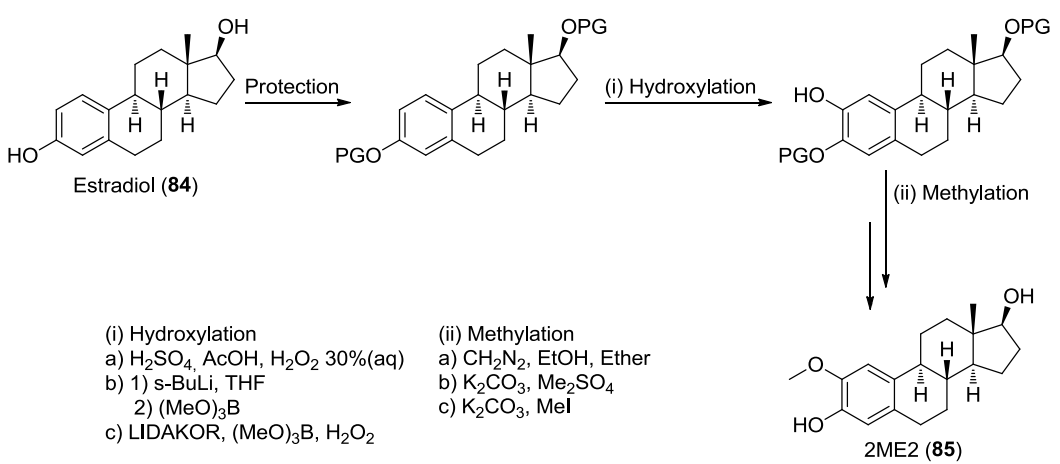

Figure 20 Synthesis of 2ME2 from estradiol with the use of direct hydroxylation as the key step. PG = protection group. ${ }^{121-123}$

With the phenol group protected with 2-chloro-5-nitrobenzophenone and the 17ß-hydroxyl acetate the aromatic ring was ortho-hydroxylated with hydrogen peroxide under acidic conditions, and was subsequently methylated with diazomethane. The yield was not reported for this five step synthesis. $^{121}$ Paaren and co-workers (Figure 20, path b) protected estradiol (84) before hydroxylation with trimethylborate. Potassium carbonate and dimethyl sulfate was used to methylate the 2-hydroxyl group. The synthesis was complete in four steps and $78 \%$ overall yield. ${ }^{122}$ Wähälä et al. (Figure 20, path c) hydroxylated the protected estradiol with the use of the superbase LIDAKOR, trimethylborate and hydrogen peroxide. The methylation was performed with potassium carbonate and methyl iodide. 2ME2 (84) was obtained in $61 \%$ yield in three steps from estradiol. $^{123}$

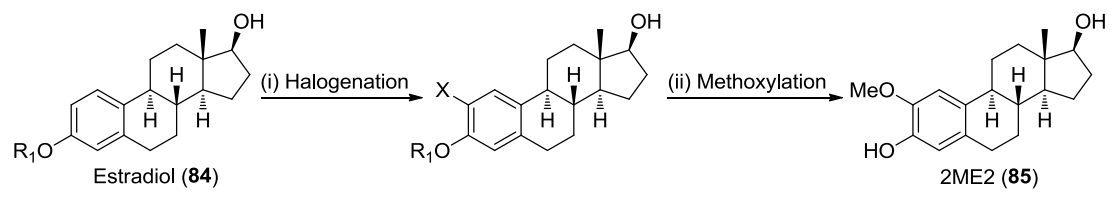
(i) $\left(\mathrm{R}_{1}=\mathrm{H}\right) \mathrm{TBCO}, \mathrm{THF}$
(ii)
b) - $\left(\mathrm{R}_{1}=\mathrm{H}\right) \mathrm{NBS}, \mathrm{CHCl}_{3}$
d) $\left(\mathrm{R}_{1}=\mathrm{Bn}\right) \mathrm{Br}_{2}, \mathrm{CH}_{2} \mathrm{Cl}_{2}$
a) $(\mathrm{X}=\mathrm{Br}) \mathrm{NaOMe}, \mathrm{Cul}, \mathrm{DMF}$
b) $(X=I) \mathrm{NaOMe}, \mathrm{CuCl}_{2}, \mathrm{MeOH}$
c) $(X=\mathrm{Br}) \mathrm{NaOMe}$, Cul, DMF
d) 1) $(\mathrm{X}=\mathrm{Br}) \mathrm{NaOMe}, \mathrm{CuBr}, \mathrm{EtOAc}, \mathrm{MeOH}$
2) $10 \% \mathrm{Pd} / \mathrm{C}, \mathrm{H}_{2}, \mathrm{EtOH}$

Figure 21 Halogenation as the key step for the synthesis of $2 \mathrm{ME} 2 .^{124-127}$

Total synthesis of 2ME2 has been achieved by using 2-halogenation and methoxylation as the key steps. Rao and co-workers (Figure 21, path a) prepared 2ME2 (85) from estradiol (84) by halogenation with TBCO. This resulted in a mixture of 2- and 4-brominated isomers with the 2isomer as the minor component. ${ }^{124}$ Methoxylation using sodium methoxide in presence of copper 
iodide afforded 2ME2 (85). This two step synthesis proceeded in $13 \%$ overall yield. ${ }^{124}$ Numazawa et al. (Figure 21, path b) reported the synthesis of $\mathbf{8 5}$ from the corresponding 2-iodo compound using sodium methoxide and copper chloride. This one step procedure afforded $2 \mathrm{ME} 2$ in $95 \%$ yield. ${ }^{125}$ Zhao and co-workers (Figure 21, path c) used NBS in chloroform to halogenate estradiol resulting in an almost 1:1 mixture of 2- and 4-brominated estradiol. The methoxylation reaction was performed using sodium methoxide and copper iodide in the presence of benzo-15-crown-5. This two step synthesis proceeded in $30 \%$ overall yield. ${ }^{126}$ Xiang and co-workers (Figure 21, path d) performed the halogenation on 3-O-benzyl-protected estradiol using bromine in dichloromethane, the bromination then occurred regioselectively at the 2-postion. The methoxylation was also in this case copper-mediated and the authors used ethyl acetate $(60 \mathrm{~mol} \%)$ as a co-catalyst. Removal of the benzyl group afforded $\mathbf{8 5}$ in four steps and $61 \%$ overall yield. ${ }^{127}$

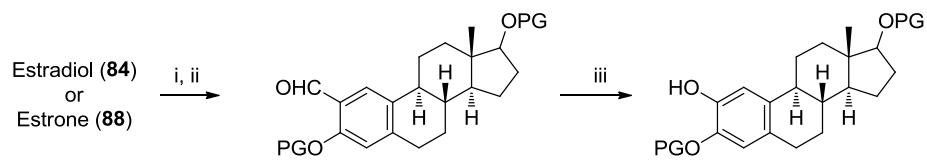

(i)

(ii)

a) $\mathrm{NaH}, \mathrm{TBA}, \mathrm{BnBr}, \mathrm{DMF}$

b) s-BuLi, DMF, THF

c) s-BuLi, DMF, THF (iii)

a) $m$-CPBA, $p$-TsOH, DCM

b) $m$-CPBA, $\mathrm{Na}_{2} \mathrm{HPO}_{4}, \mathrm{DCM}$

c) $m$-CPBA, $\mathrm{Na}_{2} \mathrm{HPO}_{4}, \mathrm{DCM}$

b) 84 , DIPEA, MOMCl, THF 2) $\mathrm{NaH}, \mathrm{MOMCl}, \mathrm{DMF}$

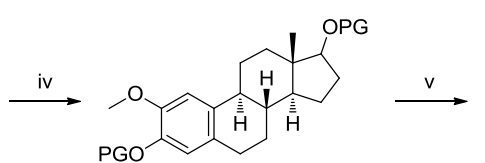

(iv)

a-c) $\mathrm{K}_{2} \mathrm{CO}_{3}$, TBAI, Mel, DMF

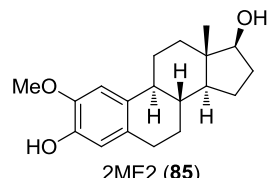

(v)

a) $\mathrm{H}_{2}, \mathrm{Pd} / \mathrm{C}, \mathrm{THF}$

b) $\mathrm{HCl}$, THF

c) 1) $\mathrm{HCl}$, THF

2) $\mathrm{NaBH}_{4}, \mathrm{THF}$, IPA

Figure 22 Total synthesis using the 2-formylation, oxidation and methylation as the key steps. ${ }^{128-130}$

Several groups have employed 2-formylation, oxidation and methylation as the key steps for the syntheses of 2ME2 (85). Cushman and co-workers (Figure 22, path a) formylated estradiol by employing Duff reaction conditions, which yielded a mixture of two isomers with the 2-isomer as the major product. The hydroxyl groups were protected using benzyl bromide, followed by a Baeyer-Villiger/Dakin oxidation of the formyl group. The 2-hydroxyl group was methylated before deprotection to the final compound. 2ME2 was prepared in five steps and $6 \%$ overall yield. ${ }^{128}$ Some years later the same group reported a similar, but improved, synthetic pathway changing the protection group and formylation chemistry as described by Pert ${ }^{131}$ and Brueggemeier, ${ }^{132}$ selectively 
formylating the 2-position of 3,17 $\beta$-bis(MOM) protected estradiol (Figure 22, path b). Furthermore, the authors improved the Baeyer-Villiger oxidation conditions which resulted in a five step synthesis with $63 \%$ overall yield of $2 \mathrm{ME} 2 .{ }^{129}$ Leese et al. (Figure 22, path c) devised a synthetic pathway from estrone (88). After protection of the ketone and hydroxyl groups as an acetal and a MOM ether, respectively, the authors proceeded with formylation, oxidation and methylation as described earlier by others. 2ME2 (85) was isolated after dual deprotection and reduction of the 17keto group with $\mathrm{NaBH}_{4}$. This seven step synthesis afforded $\mathbf{8 5}$ in $58 \%$ overall yield. ${ }^{130}$

There are procedures for the synthesis of $2 \mathrm{ME} 2(\mathbf{8 5})$ that can not be categorized into either of the previously described strategies. Amouri et al. prepared $\mathbf{8 5}$ by selective ortho-activation of the aromatic ring of estradiol towards nucleophilic attack by the $\mathrm{Cp}^{*} \operatorname{Ir}^{2+}$-complex. Sodium methoxide reacted explicitly at $\mathrm{C}-2$ of the estradiol- $\mathrm{Cp}^{*} \mathrm{Ir}^{2+}$-complex installing the 2-methoxy group. Subsequent oxidative decomplexation afforded compound $\mathbf{8 5}$ in three steps and $60 \%$ overall yield. However, the iridium reagent was used in stoichiometric amounts. ${ }^{133}$

A second 2ME2 (85) synthesis by Rao and co-workers utilized a 2-acyl group instead of a 2-formyl group, synthesized by a zirconium-tetrachloride mediated Fries rearrangement. The previously mentioned Baeyer-Villiger oxidation and methylation procedures afforded $2 \mathrm{ME} 2$ in $40 \%$ overall yield and seven steps. The authors used five equivalents of zirconium-tetrachloride for the Fries rearrangement. $^{134}$

Hou and co-workers used a direct methoxylation procedure involving C-2 lithiation followed by reaction with cumyl methyl peroxide, thus preparing $2 \mathrm{ME} 2$ in three steps and $70 \%$ overall yield. Though, cumyl methyl peroxide might be shock sensitive and undesirable to handle in large quantities. $^{135}$

The synthesis reported by Stoelwinder and Moers in a patent from 2006 differs from the other reported syntheses. There have been some concern about estrogenic contaminants in the 2methoxyestradiol product; therefore the authors envisioned to build the steroid skeleton by stepwise synthesis. The two compounds $\mathbf{8 9}$ and $\mathbf{9 0}$ are combined to make up the different parts of the steroid skeleton. Which after two ring closures (91) and aromatization of ring A, as well as a reduction of the ketogroup in the 17 position afforded 2ME2 in seven steps (Figure 23). It was not possible to determine the overall yield of the synthesis as they are not reported in the patent. There is a clear advantage in avoiding estrogenic contaminants, which can possibly affect the results of biological testing. ${ }^{136}$ 


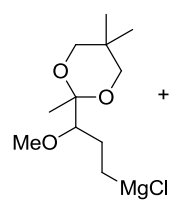

89

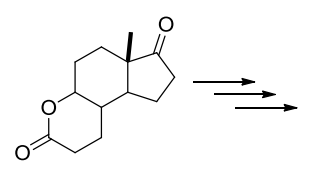

90

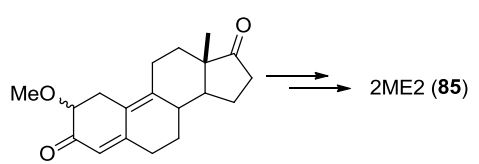

91

Figure 23 Outline of total synthesis of 2ME2 from non-estrogenic starting materials.

\subsection{Molecular modelling}

Since 1970 computers have been readily available for academic applications and several researchers embarked on a mission to make an algorithm that would enable docking of small ligands into receptors in silico. The first docking program emerged in 1982 when Kuntz and co-workers published a computer aided molecular docking on a minicomputer (PDP 11/70) using the known xray structures of heme docked into myoglobin and other known protein-ligand complexes. ${ }^{137}$ Today more than 60 programs and 30 algorithms are available, but only a limited number of them are widely used (AutoDock, DOCK, FlexX, FRED, Glide, GOLD, ICM, QXP/Flo+ and Surflex). ${ }^{138}$ For the most part, generating reasonable ligand orientation is considered to be virtually solved, whereas imperfections of scoring functions continue to be a major limiting factor. ${ }^{139-141}$ With an everincreasing number of protein structures being solved by X-ray crystallography, the use of proteinligand docking algorithms to assess candidate ligands for a binding site has become commonplace. However, the techniques and practice of protein-ligand docking in general, and of structure-based virtual screening in particular, are still evolving and significant limitations remain to be addressed. ${ }^{142}$ A second virtual technique for the identification of new drug leads is ligand-based approaches, which require much less detailed information. At a minimum, a ligand-based technique requires knowledge of only one active molecule. The virtual screen is then conducted by identifying molecules that share some similarity or properties with that single active molecule. The best known among these techniques is the pharmacophore approach, which attempts to abstract features of an active molecule (or shared features among a set of active molecules) that are likely to be important in binding to the target receptor. ${ }^{143}$ 


\subsubsection{Tubulin structure and colchicine binding}

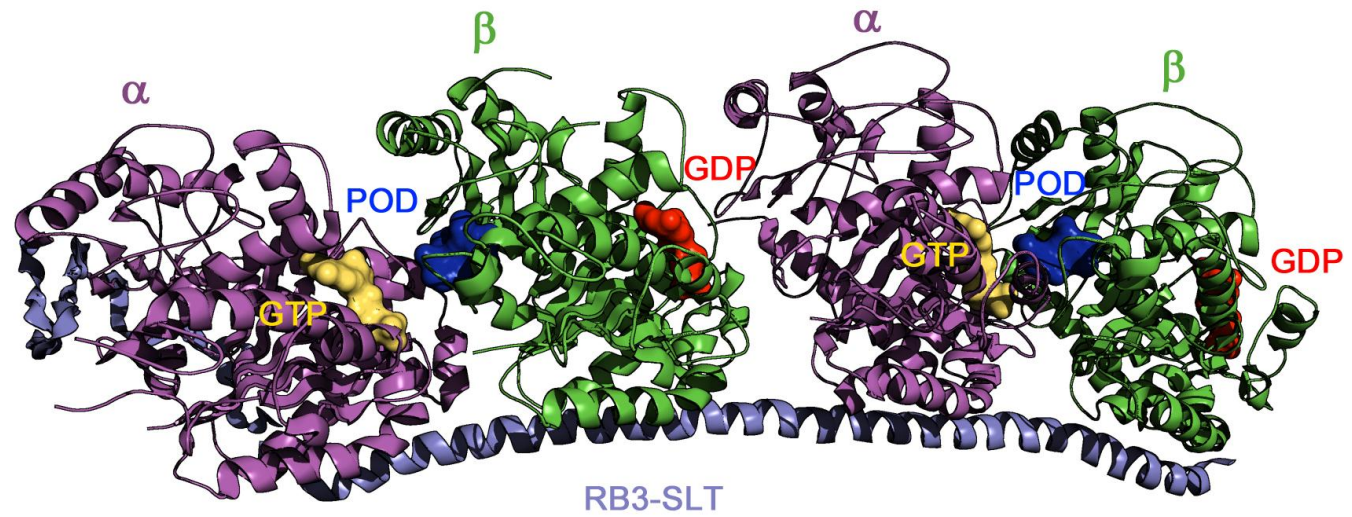

Figure 24 The pdb entry 1SA1 of $\alpha, \beta$-tubulin hetero-dimer in complex with RB3-SLD and podophyllotoxin (POD, blue).

The colchicine binding site was finally identified in 2004 by Ravelli and co-workers; a x-ray crystal structure of $\alpha, \beta$-tubulin hetero-dimer in complex with RB3 protein stathmin-like-domain (RB3SLD) and DAMA-colchicine or podophyllotoxin (pdb entry $1 \mathrm{SA} 0$ and $1 \mathrm{SA} 1$, respectively) (Figure 24). ${ }^{7}$ The binding site of colchicine was located at the intradimer interface of $\alpha, \beta$-tubulin in a lipophilic pocket.
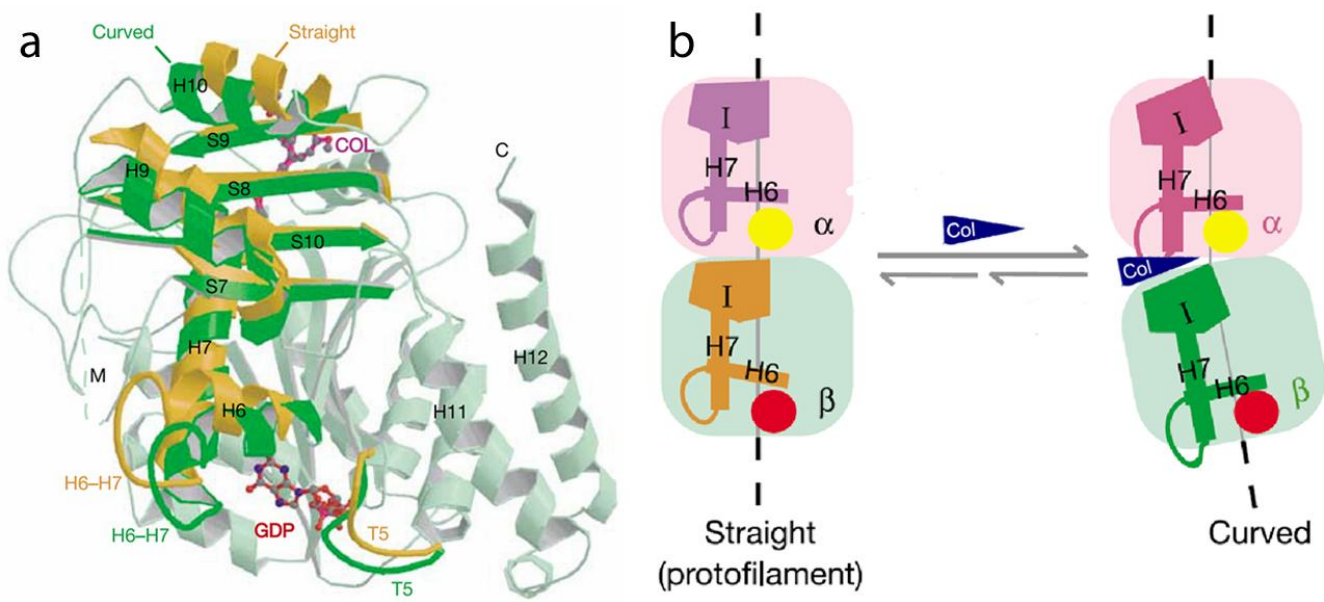

Figure 25 (a) $\beta$-Tubulin without (yellow) with bound colchicine (green) superimpose over one another, the root mean square deviations of the positions of $\mathrm{C} \alpha$ atoms in secondary structure elements after superposition is $0.8 \AA$. (b) Colchicine (blue) inhibits the $\alpha, \beta$-tubulin hetero dimer from adopting a straight conformation. Adapted from reference. ${ }^{7}$ 
The colchicine binding site is mostly buried in the intermediate domain of the $\beta$-subunit, boxed in by strands S8 and S9, loop T7 and helices H7 and H8 (Figure 25). Colchicine also interacts with loop T5 of the neighbouring $\alpha$-subunit. Microtubule stability requires both longitudinal (between tubulin subunit $\alpha$ and $\beta$ ) and lateral interactions (between protofilaments). When colchicine binds to tubulin, it acts as a wedge between the $\alpha$ and $\beta$ tubulin hindering the protofilament to adopt a straight conformation. The curved tubulin-colchicine complex cannot establish lateral contacts at the newly formed end of the protofilament because the M loop is displaced. ${ }^{7}$

Several molecular modelling studies, both ligand-based and structure-based, of colchicine site inhibitors have been reported. The structure-based approaches have resulted in the identification of several residues and interactions supposedly involved in the binding of inhibitors to the colchicine site. $^{8}$

\section{7 ortho-Formylation of phenols}

\subsubsection{History}

Salicylaldehydes are useful intermediates in organic synthesis. This class of compounds are accessible in several ways starting from substituted phenols (Figure 26). However, for many of these classical reactions, the yields of salicylaldehydes are often only moderate and the lack of regioselectivity is problematic. Moreover, the reaction conditions are quite harsh, involve safety problems at a large scale, and employ environmentally harmful reagents. ${ }^{144-158}$

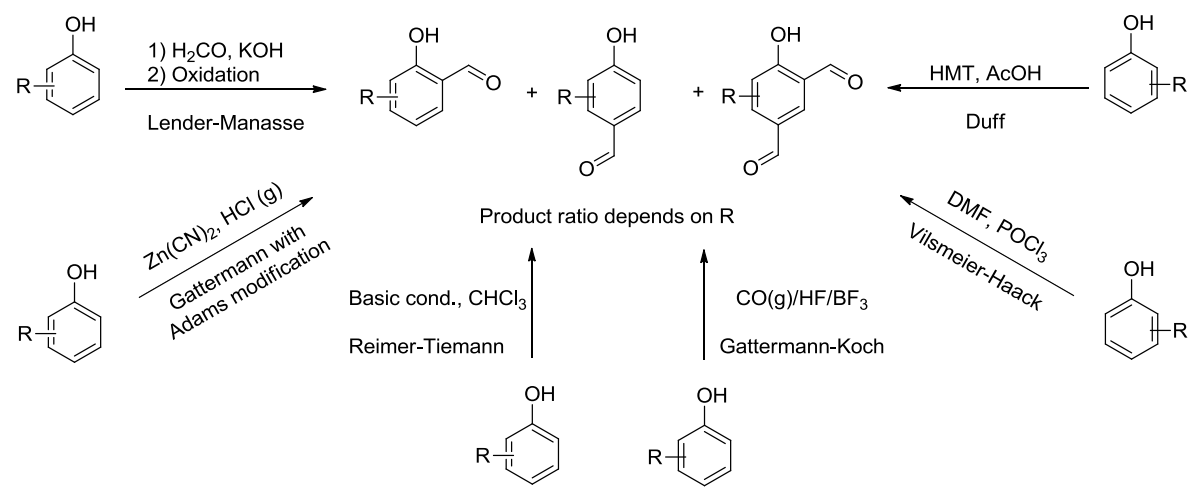

Figure 26 Classic formylation reactions of phenols: Lender-Manasse, ${ }^{149,150}$ Gattermann, ${ }^{151,152,156}$ ReimerTiemann, ${ }^{145-147,156,159}$ Gattermann-Koch, ${ }^{160-162}$ Vilsmeier-Haack ${ }^{153,156,158}$ and Duff reaction ${ }^{154-156}$. 
The selectivity issue has been partly solved for some of the reactions, for instance the ReimerTiemann yields the salicylaldehyde when $\mathrm{H}_{2} \mathrm{O} / \mathrm{EtOH} 9: 1(\mathrm{v} / \mathrm{v} \%)$ is used as solvent. ${ }^{163}$ The original Gattermann-Koch reaction using carbon monoxide under acidic conditions is incompatible with phenols. When hydrogen fluoride and boron trifluoride are used as acids the reaction yields primarily 4-hydroxybenzaldehydes. ${ }^{161,162}$ Salts of chromium, zirconium, titanium and iron were shown to successfully ortho-formylate phenols at high temperatures and pressure. ${ }^{164,165}$

In 1978 a highly selective method for the ortho-formylation of phenols was published by Casiraghi and co-workers, employing ethylmagnesium bromide, hexamethylphosphoramide (HMPA) and paraformaldehyde in refluxing benzene. ${ }^{166}$ The authors obtained 2-hydroxybenzaldehydes as the only regioisomer in 50-90\% yields from phenols substituted with alkyl, alkoxy or chloride groups. The method was later modified by the same group; tin tetrachloride and tributylamine in refluxing toluene replaced the former solvent and base system (Scheme 4). ${ }^{167}$ When phenols substituted with ortho-methoxy, nitro, ester or methylketone groups were submitted to either of the reaction conditions, no formation of the corresponding aldehydes were observed. Levin et al. and $\mathrm{Bu}$ et al. both improved the method. ${ }^{168,169}$

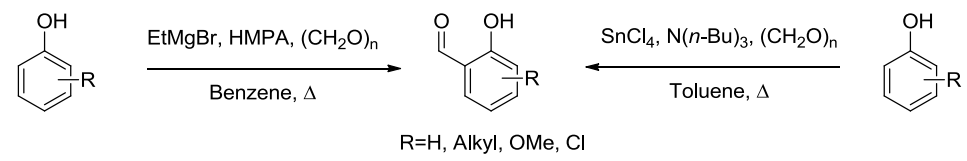

Scheme 4 Two methods by Casiraghi and co-workers for the ortho-formylation of phenols.

Unfortunately, all these reactions are hampered by one or more of the following disadvantages: the use of large amounts of Lewis acids, hazardous reagents, difficult separations of isomers, and multistep synthesis. Today, there is a general need for more environmentally benign methods.

In 1999 Skattebøl and Hofsløkken published a convenient ortho-formylating protocol using anhydrous magnesium dichloride, triethylamine and paraformaldehyde in refluxing acetonitrile or THF (Scheme 5). ${ }^{170}$ This base system gives higher yields, fewer by-products, and the use of HMPA becomes redundant. The reaction was later improved by Hansen and Skattebøl by reducing the number of equivalents of magnesium dichloride, triethylamine, and paraformaldehyde to two, two, and three, respectively. Salicylaldehydes are obtained in good to excellent yields, 70-99\%, using this method. Unfortunately only poor yields were obtained using phenols substituted with electron withdrawing groups such as nitrile and nitro, except methyl 4-hydroxybenzoate which was formylated with a yield of $88 \% .^{171}$ 


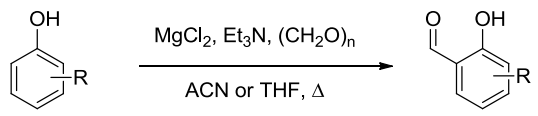

$\mathrm{R}=\mathrm{H}, \mathrm{Me}, t-\mathrm{Bu}, \mathrm{Cl}, 3-\mathrm{OMe}, 4-\mathrm{OMe}, 4-\mathrm{COOMe}$

Scheme 5 Preparation of salicylaldehydes by ortho-formylation using the $\mathrm{MgCl}_{2} / \mathrm{Et}_{3} \mathrm{~N}$ base system.

Skattebøl and Hofsløkken proposed a reaction mechanism for the ortho-formylation reaction with magnesium dichloride which is analogous to that of Casiraghi, when magnesium or tin phenoxides are employed. ${ }^{166,167,170}$ The phenoxymagnesium salt (A) coordinates formaldehyde for an electrophilic aromatic substitution. After aromatization (B), the salicylalcohol reacts in an Oppenauer-Tishchenko type oxidation ${ }^{172,173}$ with a second equivalent of formaldehyde $(\mathrm{C})$ yielding the corresponding salicylaldehyde (Figure 27).

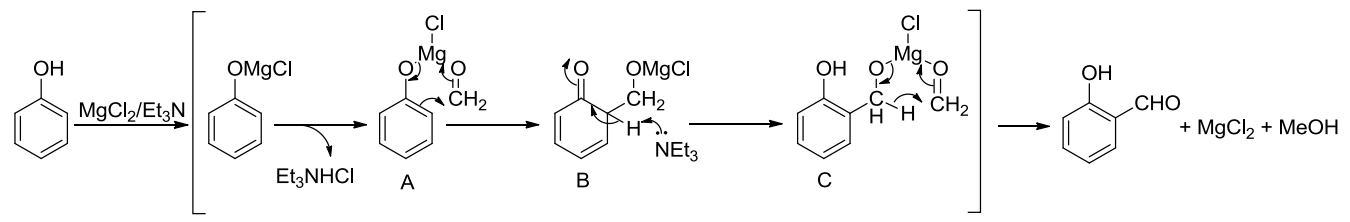

Figure 27 Proposed ortho-formylation reaction mechanism. Adapted from reference. ${ }^{170,174}$

The magnesium dichloride/triethylamine base system has been employed for the preparation of useful intermediates and natural products. ${ }^{81,82,171,175-184}$

\subsubsection{Formylation of resorcinols}

Regioselectivity in formylation of phenols and resorcinols can be a problem as illustrated in Figure 28.

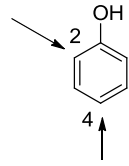

ortho/para selectivity

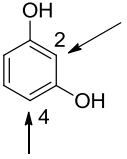

ortho-ortho/ortho-para selectivity

Figure 28 Substitute patterns on phenol and resorcinols in formylation reactions.

To some extent selectivity between C-2 and C-4 on resorcinol or its mono- or diprotected derivatives can be controlled. C-2 is deprotonated if phenyl lithium, $n$-BuLi or sodium sand is used as reagent; subsequently adding DMF or $N$-methyformanilide yields the C-2 formylated product. ${ }^{185-}$ 
189 While C-4 is formylated when Gattermann/Adams, ${ }^{151,152}$ Gross, ${ }^{190}$ Vilsmeier-Haack ${ }^{191-193}$ or reaction methods derived thereof ${ }^{194,195}$ are employed. Yields are in the range of $45-99 \%$. The Reimer-Tiemann reaction with resorcinol or its monomethyl ether gives acceptable yields in combination with $\beta$-cyclodextrin. ${ }^{196}$ Reaction conditions and yields of reported formylations of resorcinols are summarised in Table 1.

Table 1 Reported formylations of resorcinols.

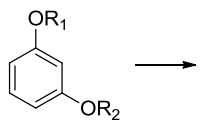

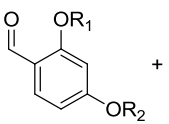

92

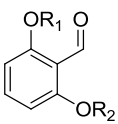

93

\begin{tabular}{|c|c|c|c|c|c|c|}
\hline Year & Author & Conditions & $\mathrm{R}_{1}$ & $\mathrm{R}_{2}$ & Yield 92 & Yield 93 \\
\hline \multirow[t]{2}{*}{1898} & Gattermann, L. ${ }^{151}$ & $\mathrm{HCN}, \mathrm{AlCl}_{3}$, Benzene & $\mathrm{H}$ & $\mathrm{H}$ & $99 \%$ & - \\
\hline & & $\mathrm{HCN}, \mathrm{AlCl}_{3}$, Benzene & $\mathrm{Me}$ & $\mathrm{H}$ & $80 \%$ & - \\
\hline 1923 & Adams, R. ${ }^{152}$ & $\mathrm{Zn}(\mathrm{CN})_{2}, \mathrm{HCl}, \mathrm{Et}_{2} \mathrm{O}$ & $\mathrm{H}$ & $\mathrm{H}$ & $95 \%$ & - \\
\hline 1940 & Wittig, G. ${ }^{185}$ & $\begin{array}{l}\text { 1) } \mathrm{PhLi}, \mathrm{Et}_{2} \mathrm{O} \\
\text { 2) } \mathrm{N} \text {-methyformanilide }\end{array}$ & $\mathrm{Me}$ & $\mathrm{Me}$ & - & $55 \%$ \\
\hline 1952 & Sommers, A. H. ${ }^{191}$ & $\begin{array}{l}\mathrm{POCl}_{3}, N \text {-methyformanilide, } \\
<34{ }^{\circ} \mathrm{C}\end{array}$ & $\mathrm{Me}$ & $\mathrm{Me}$ & $85 \%$ & - \\
\hline \multirow[t]{2}{*}{1955} & Lambooy, J.P. ${ }^{192}$ & $\begin{array}{l}\mathrm{POCl}_{3}, N \text {-methyformanilide, } \\
100{ }^{\circ} \mathrm{C}\end{array}$ & $\mathrm{Me}$ & $\mathrm{Me}$ & $72 \%$ & - \\
\hline & & $\mathrm{POCl}_{3}, \mathrm{DMF}, 100^{\circ} \mathrm{C}$ & $\mathrm{Me}$ & $\mathrm{Me}$ & $68 \%$ & - \\
\hline 1963 & Gross, $\mathrm{H}^{190}$ & $\begin{array}{l}\mathrm{Cl}_{2} \mathrm{CHOMe} \text { or } \mathrm{HC}(\mathrm{OEt})_{3}, \mathrm{AlCl}_{3} \text {, } \\
\mathrm{PhNO}_{2}\end{array}$ & $\mathrm{H}$ & $\mathrm{H}$ & $68 \%$ & - \\
\hline 1979 & Narasimhan, N. S. ${ }^{186}$ & $\begin{array}{l}\text { 1) } n-\mathrm{BuLi}, \mathrm{Et}_{2} \mathrm{O}, \mathrm{rt} \\
\text { 2) } \mathrm{DMF}\end{array}$ & MOM & $\mathrm{Me}$ & - & $90 \%$ \\
\hline \multirow[t]{2}{*}{1993} & Heaney, H. ${ }^{194}$ & $\mathrm{P}_{2} \mathrm{O}_{3} \mathrm{Cl}_{4}, \mathrm{DMF}, 20^{\circ} \mathrm{C}$ & $\mathrm{H}$ & $\mathrm{H}$ & $88 \%$ & - \\
\hline & & $\mathrm{P}_{2} \mathrm{O}_{3} \mathrm{Cl}_{4}, \mathrm{DMF}, 100^{\circ} \mathrm{C}$ & $\mathrm{Me}$ & $\mathrm{Me}$ & $99 \%$ & - \\
\hline \multirow[t]{2}{*}{1996} & Mendelson, W. L. ${ }^{193}$ & $\mathrm{POCl}_{3}, \mathrm{DMF}, \mathrm{ACN},-14^{\circ} \mathrm{C}$ & $\mathrm{H}$ & $\mathrm{H}$ & $70-75 \%$ & - \\
\hline & & $(\mathrm{COCl})_{2}, \mathrm{DMF}, \mathrm{ACN},-14^{\circ} \mathrm{C}$ & $\mathrm{H}$ & $\mathrm{H}$ & $66-70 \%$ & - \\
\hline 1997 & O'Brien, $\mathrm{P}^{187}$ & $\begin{array}{l}\text { 1) } n \text {-BuLi, TMEDA, } \mathrm{Et}_{2} \mathrm{O}, 0{ }^{\circ} \mathrm{C} \\
\text { 2) } \mathrm{DMF}, \mathrm{rt}\end{array}$ & $\begin{array}{l}\text { Benzyl } \\
\text { derivatives }\end{array}$ & $\begin{array}{c}\text { Benzyl } \\
\text { derivatives }\end{array}$ & - & $38-75 \%$ \\
\hline \multirow[t]{2}{*}{1997} & Zacharie, B. ${ }^{188}$ & $\begin{array}{l}\text { 1) } n \text {-BuLi, } \mathrm{Et}_{2} \mathrm{O}, 0{ }^{\circ} \mathrm{C} \\
\text { 2) } \mathrm{DMF}\end{array}$ & THP & $\mathrm{Me}$ & - & $76 \%$ \\
\hline & & $\begin{array}{l}\text { 1) } n \text {-BuLi, } \mathrm{Et}_{2} \mathrm{O}, 0{ }^{\circ} \mathrm{C} \\
\text { 2) } \mathrm{DMF}\end{array}$ & THP & MOM & $4 \%$ & $62 \%$ \\
\hline 2001 & $\begin{array}{l}\text { Bagno, A. } \\
\text { Kantlehner, W. }{ }^{195}\end{array}$ & $\begin{array}{l}\mathrm{AlCl}_{3} \text {, tris (diformylamino) } \\
\text { methane, DCE, }-15^{\circ} \mathrm{C}\end{array}$ & $\mathrm{Me}$ & $\mathrm{Me}$ & $45 \%$ & - \\
\hline \multirow[t]{2}{*}{2001} & Divakar, S. ${ }^{196}$ & $\begin{array}{l}\mathrm{KOH}, \mathrm{CHCl}_{3}, \beta \text {-cyclodextrin, } \\
\mathrm{H}_{2} \mathrm{O}, 60^{\circ} \mathrm{C}\end{array}$ & $\mathrm{H}$ & $\mathrm{H}$ & $70 \%$ & $-(16 \%)^{\mathrm{a}}$ \\
\hline & & $\begin{array}{l}\mathrm{KOH}, \mathrm{CHCl}_{3}, \beta \text {-cyclodextrin, } \\
\mathrm{H}_{2} \mathrm{O}, 60^{\circ} \mathrm{C}\end{array}$ & $\mathrm{H}$ & $\mathrm{Me}$ & $44 \%$ & $-(56 \%)^{\mathrm{a}}$ \\
\hline 2002 & Wagner, A. ${ }^{189}$ & $\begin{array}{l}\text { Na sand, } \mathrm{C}_{8} \mathrm{H}_{17} \mathrm{Cl}, \mathrm{DMF}, \\
\text { toluene, } \mathrm{rt}\end{array}$ & $\mathrm{Me}$ & $\mathrm{Me}$ & - & $52 \%$ \\
\hline
\end{tabular}

${ }^{\mathrm{a}}$ Yield of dialdehydes 


\subsubsection{Formylation of estradiol}

Many of the previously mentioned formylation reaction methods have been applied to estradiol (84). Reaction conditions and yields of reported formylations of estradiol are summarised in Table 2. In 1966 the company Organon N. V. filed a patent describing the formylation of estradiol (84) by the Reimer-Tiemann reaction. Several research groups have tried to repeat the reaction but only with limited success. ${ }^{131,197}$

Table 2 Reported ortho-formylation of estradiol.

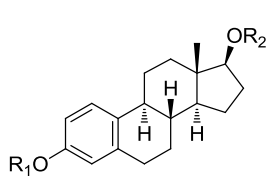

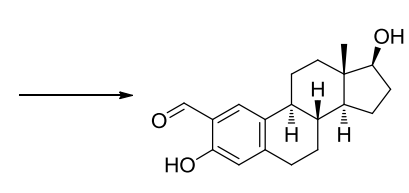

94

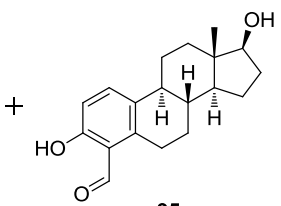

95

\begin{tabular}{|c|c|c|c|c|c|c|}
\hline Year & Author & Conditions & $\mathrm{R}_{1}$ & $\mathrm{R}_{2}$ & Yield 94 & Yield 95 \\
\hline 1966 & Organon N. V. ${ }^{198}$ & $\begin{array}{l}1.5 \mathrm{~N} \mathrm{NaOH} \text { EtOH }(69 \%), \\
\mathrm{CHCl}_{3}, 70^{\circ} \mathrm{C}\end{array}$ & $\mathrm{H}$ & $\mathrm{H}$ & $-^{\mathrm{a}}$ & $-{ }^{a}$ \\
\hline 1988 & Rugang, $X .{ }^{199}$ & $\begin{array}{l}\text { EtMgBr, HMPA, }\left(\mathrm{CH}_{2} \mathrm{O}\right)_{n} \text {, } \\
\text { Benzene, } 80^{\circ} \mathrm{C}\end{array}$ & $\mathrm{H}$ & $\mathrm{H}$ & $\begin{array}{l}25 \% \\
(21 \%)^{\mathrm{b}}\end{array}$ & - \\
\hline 1989 & Ridley, D. D. ${ }^{131}$ & $\begin{array}{l}\text { 1) } s \text {-BuLi, DMF, THF, }-78^{\circ} \mathrm{C} \\
\text { 2) } 6 \mathrm{M} \mathrm{HCl}, \mathrm{THF}\end{array}$ & MOM & MOM & $75 \%$ & - \\
\hline 1991 & Kourounakis, P. N. ${ }^{197}$ & $\begin{array}{l}\text { 1) EtMgBr, } \mathrm{HMPA},\left(\mathrm{CH}_{2} \mathrm{O}\right)_{n} \text {, } \\
\text { Benzene, } 80^{\circ} \mathrm{C} \\
\text { 2) } 20 \% \mathrm{NaOH}, \mathrm{MeOH}\end{array}$ & $\mathrm{H}$ & $\mathrm{H}$ & $\begin{array}{l}68 \% \\
(27 \%)^{\mathrm{b}}\end{array}$ & - \\
\hline $1994 / 5$ & Cushman, M. ${ }^{128,200}$ & $\mathrm{HMT}, \mathrm{CF}_{3} \mathrm{COOH}, \Delta$ & $\mathrm{H}$ & $\mathrm{H}$ & $25 \%$ & $13 \%$ \\
\hline 1995 & El-Tombary, A. A. ${ }^{201}$ & $\begin{array}{l}\text { 1) TMDM, }\left(\mathrm{CH}_{2} \mathrm{O}\right)_{n} \text {, benzene, } \\
\text { EtOH, } \Delta \\
\text { 2) HMT, AcOH, } 65^{\circ} \mathrm{C}\end{array}$ & $\mathrm{H}$ & $\mathrm{H}$ & $36 \%$ & - \\
\hline $\begin{array}{l}1996 / \\
2001\end{array}$ & Brueggemeier, R. W. ${ }^{132,202}$ & $\begin{array}{l}\text { 1) } s \text {-BuLi, DMF, THF, }-78^{\circ} \mathrm{C} \\
\text { 2) } 6 \mathrm{M} \mathrm{HCl}, \mathrm{THF}\end{array}$ & MOM & MOM & $84 \%$ & \\
\hline 1999 & Meltola, N. ${ }^{203}$ & $\begin{array}{l}\mathrm{EtMgBr},\left(\mathrm{CH}_{2} \mathrm{O}\right)_{\mathrm{n}},\left(\mathrm{Et}_{3} \mathrm{PO}_{4} \text {, }\right. \\
\mathrm{Et}_{2} \mathrm{O} / \text { Toluene, } 80{ }^{\circ} \mathrm{C}\end{array}$ & $\mathrm{H}$ & $\mathrm{H}$ & $50 \%$ & $12 \%$ \\
\hline \multirow[t]{2}{*}{2003} & Peters, R. H. ${ }^{204}$ & $\mathrm{HMT}, \mathrm{CF}_{3} \mathrm{COOH}, 100^{\circ} \mathrm{C}$ & $\mathrm{H}$ & $\mathrm{H}$ & $13 \%$ & $4 \%$ \\
\hline & & $\begin{array}{l}\text { 1) EtMgBr, } \mathrm{HMPA},\left(\mathrm{CH}_{2} \mathrm{O}\right)_{\mathrm{n}} \text {, } \\
\text { Benzene, } 80^{\circ} \mathrm{C} \\
\text { 2) } 20 \% \mathrm{NaOH}, \mathrm{MeOH}\end{array}$ & $\mathrm{H}$ & $\mathrm{H}$ & $94 \%$ & - \\
\hline
\end{tabular}

${ }^{\mathrm{a}}$ Not reported

${ }^{\mathrm{b}}$ Yield of $17 \beta$-formate (96) 
By using a heteroatom facilitated ortho-lithiation process and DMF, Ridley and co-workers were able to regioselectively formylate the 2-position of 3,17 $\beta$-bis(methoxymethoxy) estradiol. ${ }^{131}$ The groups of Peters and Cushman have formylated estradiol under Duff reaction conditions (HMT, acidic cond.), but a mixture of the 2- and 4-regioisomeres was obtained. Only small amounts of 2formylestradiol (94) was isolated using this method. ${ }^{128,200,204}$ Rugang and co-workers orthoformylated several estrogens using Casiraghi conditions (EtMgBr, HMPA and paraformaldehyde), and reported yields of 25\% for 2-formyl estradiol (94) and a 21\% yield of the corresponding $17 \beta$ formate (96, Figure 29). ${ }^{199}$ Meltola and co-workers obtained 94 and 95 in a $62 \%$ combined yield using triethyl phosphate instead of HMPA with the Casiraghi conditions. ${ }^{203}$ Peters and Kourounakis both discarded their earlier formylation attempts with the Duff conditions to the advantage of the Casiraghi method. Both groups obtained 2-formyl estradiol (94) in a combined yield of 94\% after hydrolysis of the corresponding formate ester. ${ }^{197,204}$

A side reaction that occurs with the Casiraghi method is the trans esterification of the 17ß-hydroxyl group with methyl formate (97) (Figure 29). Methyl formate is most likely a byproduct due to a Tishchenko type reaction. ${ }^{172,174}$ Kourounakis and Peters reported this side reaction, and unlike Rugang et al., they hydrolysed the $17 \beta$-formate of 2-formyl estradiol (96) to the desired compound 94. ${ }^{197,199,204}$

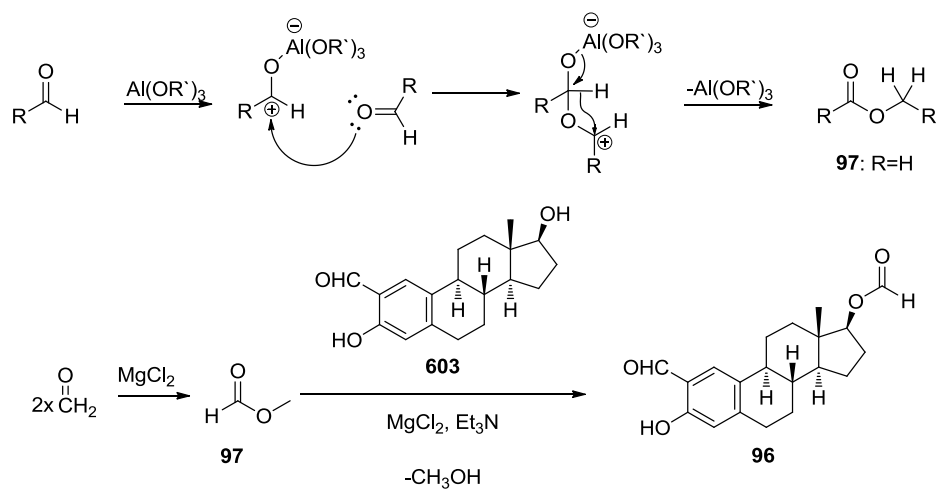

Figure 29 The Tishchenko reaction mechanism and the trans esterification of 94 with methyl formate.

An indirect route to 2-formylestradiol (94) is by aromatization of 2-hydroxymethylene-19nortestosterone (98) with DDQ in dioxane (Figure 30). ${ }^{205,206}$ This method was also applied to compound 99 for the synthesis of the corresponding 2-formylestrogen (100) (Figure 30). ${ }^{207}$ 

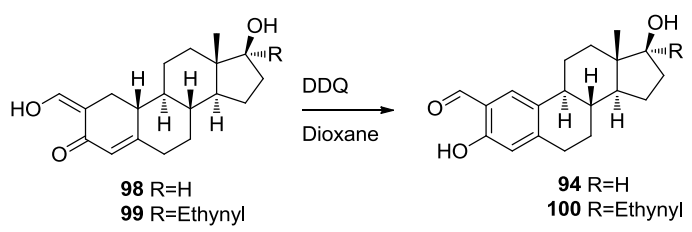

Figure 30 Synthesis of 2-formyl estradiol and $17 \alpha$-ethynyl derivative by aromatization. ${ }^{205,206}$

\subsubsection{Formylation of estrone}

As with estradiol, several research groups have attempted the formylation of estrone. The reported syntheses are summarized in Table 3 . The yields are only acceptable at best.

Table 3 Reported ortho-formylations of estrone and one estrone derivative.
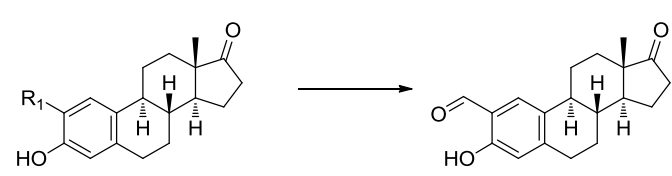

101

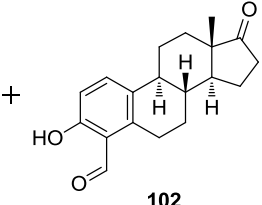

102

\begin{tabular}{|c|c|c|c|c|c|}
\hline Year & Author & Conditions & $\mathrm{R}_{1}$ & Yield 101 & Yield 102 \\
\hline 1966 & Organon N. V. ${ }^{198}$ & $\begin{array}{l}1.5 \mathrm{~N} \mathrm{NaOH}^{\circ} \mathrm{EtOH}(69 \%), \\
\mathrm{CHCl}_{3}, 70^{\circ} \mathrm{C}\end{array}$ & $\mathrm{H}$ & $\mathrm{s}^{\mathrm{a}}$ & $-^{a}$ \\
\hline 1988 & Rugang, X. ${ }^{199}$ & $\begin{array}{l}\text { EtMgBr, HMPA, }\left(\mathrm{CH}_{2} \mathrm{O}\right)_{n}, \\
\text { Benzene, } 80^{\circ} \mathrm{C}\end{array}$ & $\mathrm{H}$ & $19 \%$ & - \\
\hline 1989 & Ridley, D. D. ${ }^{131}$ & $\begin{array}{l}1.5 \mathrm{~N} \mathrm{NaOH}, \mathrm{EtOH}(95 \%), \\
\mathrm{CHCl}_{3}, \mathrm{BnN}(\mathrm{Et})_{3} \mathrm{Cl}, \Delta\end{array}$ & $\mathrm{H}$ & $2 \%$ & $16 \%$ \\
\hline 2004 & Taylor, S. D. ${ }^{208}$ & $\begin{array}{l}\mathrm{MgCl}_{2}, \mathrm{Bu}_{3} \mathrm{~N},\left(\mathrm{CH}_{2} \mathrm{O}\right)_{\mathrm{n}} \\
\mathrm{ACN}, \text { sealed tube }, \Delta\end{array}$ & $\mathrm{H}$ & $52 \%$ & $4 \%^{b}$ \\
\hline 2007 & Taylor, S. D. ${ }^{209}$ & $\begin{array}{l}\text { 1) } \mathrm{MgCl}_{2}, \mathrm{Et}_{3} \mathrm{~N},\left(\mathrm{CH}_{2} \mathrm{O}\right)_{\mathrm{n}} \text {, } \\
\mathrm{THF}, 40^{\circ} \mathrm{C} \\
\text { 2) } \mathrm{AlCl}_{3}, \mathrm{MeNO}_{2} / \mathrm{DCM}, \mathrm{rt}\end{array}$ & $t$-Bu & - & $58 \%$ \\
\hline
\end{tabular}

${ }^{\mathrm{a}}$ Not reported

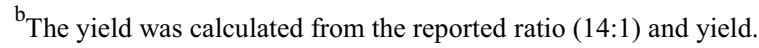

Potter and co-workers managed to formylate estrone in good yields by first protecting the 17ketogroup with ethylenglycol and thereafter the phenol as MOM ether to give intermediate $\mathbf{1 0 3}$. Formylation by ortho-lithiation and DMF yielded protected 2-formyl estrone 104 (Scheme 6). ${ }^{130}$ Rugang and co-workers also employed the Casiraghi conditions to 17 $\alpha$-ethynyl estradiol (99) and the acetal of estrone successfully, obtaining $57-78 \%$ and $62 \%$ yields of the corresponding 2 -formyl derivatives, respectively. ${ }^{199,210}$ 


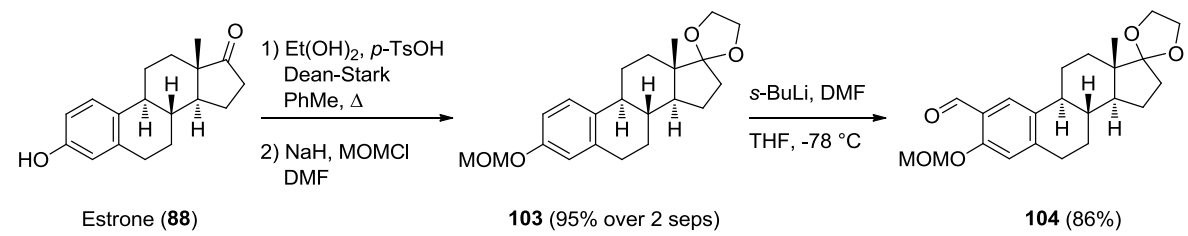

Scheme 6 Formylation of protected estrone.

Only one group has reported the synthesis of 2-formyl estriol in very poor yields. ${ }^{131}$

\subsection{1,2,3-Triazoles}

1,2,3-Triazoles are an important class of heterocycles readily available from the 1,3-dipolar cycloaddition reactions of organic azides and alkynes. ${ }^{211}$ They are interesting from a medicinal point of view because of their physical and chemical properties. The triazole ring is aromatic displaying a strong dipole moment ( $\sim 5 \mathrm{D})$, allowing the $N-2$ and $N-3$ atoms to participate in hydrogen bond formation, dipole-dipole and $\pi$ stacking interactions. Furthermore, they are stabile to acidic or basic hydrolysis as well as sever reductive and oxidative conditions. ${ }^{212}$ There are numerous reported synthetic procedures of 1,2,3-triazoles in the literature. ${ }^{213}$

\subsubsection{The Huisgen 1,3-dipolar cycloaddition reaction}

1,4- and 1,5-disubstituted 1,2,3-triazoles can be synthesized using the Huisgen cycloaddition reaction, which is a 1,3-dipolar cycloaddition reaction, between an azide and an internal or terminal alkyne. $^{214}$ This reaction yields mixtures of 1,4- and 1,5-regioisomers, and it generally requires heating and long reaction times. The reaction is thermodynamically favoured due to the high potential-energy content of the reactants, but high kinetic energy barriers render the reaction slow at room temperature. The reaction forms usually a 1:1 mixture of 1,4- and 1,5-disubstituted 1,2,3triazoles. Computational investigation of the activation barriers for the concerted reaction indicated that the barriers were quite similar for the formation two regioisomers. ${ }^{215,216}$

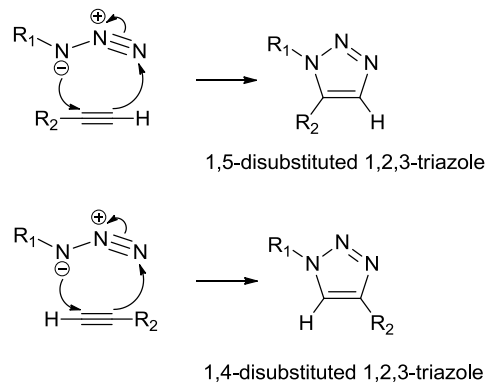

Figure 31 Proposed mechanism for the 1,3-dipolar cycloaddition between an azide and an alkyne. ${ }^{214}$ 


\subsubsection{Selective synthesis of 1,4-disubstituted-1,2,3-triazoles}

In 2002 two independent groups published procedures where copper(I) salts accelerate the Huisgen cycloaddition reaction by seven to eight orders of magnitude compared to the thermal cycloaddition. ${ }^{216-218}$ This copper catalysed azide-alkyne cycloaddition (CuAAC) is selective for the synthesis of 1,4-regioisomer. The reaction can take place at room temperature or with slightly heating in various solvents. ${ }^{218}$ Due to the extraordinary stability of alkynes and azides towards water and oxygen, protection from these elements is superfluous. In fact, many reactions proceed readily in water and it is therefore often the solvent of choice, with no organic co-solvent, as the reactants not necessarily need to be dissolved for the reaction to proceed. In addition, they tolerate a wide variety of functional groups and reaction conditions. Several groups have investigated the reaction mechanism. ${ }^{215,216,218-220}$

\subsubsection{Selective synthesis of 1,5-disubstituted-1,2,3-triazoles}

As a complimentary synthesis to the CuAAC reaction, ruthenium catalysts have been employed for alkyne-azide cycloaddition to the 1,5-disubstituted 1,2,3-triazoles. The reaction is not as versatile as the CuAAC reaction, limited by incompatibility with protic solvents and that heating or microwave irradiation is needed. Internal alkynes react readily to trisubstituted triazoles, unlike the CuAAC reaction, which requires a terminal alkyne. ${ }^{221-224}$

Recently, a transition metal free catalytic synthesis of 1,5-diaryl-1,2,3-triazoles was published, its application has yet to be investigated by the scientific community. ${ }^{225}$

Another option for the selective synthesis of 1,5-disubstituted 1,2,3-triazoles is the reaction between magnesium acetylides and azides. This method was investigated by Akimova et al. in the 1960s and they reported poor to moderate yields which might have put others off from using the method. ${ }^{226,227}$ The method was revitalized when Krasiński and co-workers tested the reported synthesis from Akimovas paper and discovered that they obtained good to excellent yields which in many cases did not require further purification by chromatography. ${ }^{228}$ Aliphatic acetylides are less reactive than the corresponding aryl acetylides. Electron-poor azides react much faster than the electron-rich azides. Byproducts are often observed when employing long reaction times without strict exclusion of oxygen, resulting in oxidative coupling reactions. The 4-halomagnesiotriazole intermediates can be trapped with electrophiles other than protons, resulting in a regioselective formation of 1,4,5trisubstituted 1,2,3-triazoles. 


\subsection{Aim of Study}

As previously mentioned, there is a great need for developing new anti-cancer drugs. Today, organic chemists should apply more environmentally benign methods for the synthesis of bioactive compounds, such as anti-cancer agents. Compared to the many classical formylation methods, such as the Reimer-Tiemann, Vilsmeier-Haack, Duff, Gattermann-Koch and Casiraghi, the Skattebøl ortho-formylation reaction offers many advantageous. The aims of this thesis were to apply this method for the synthesis of:

i. Novel PAC-1 molecules.

ii. 1,2,3-Triazole analogues of combretastatins A-1.

iii. The anti-cancer agent 2-methoxyestradiol.

In addition, most of the compounds prepared within these aims, have been subjected to biological evaluations as potential new anti-cancer agents.

In addition, we wanted to:

iv. Investigate the regioselectivity of the Skattebøl ortho-formylation reaction for oxygenated phenols. 


\section{Results and Discussion}

However beautiful the strategy, you should occasionally look at

the results.

Sir Winston Churchill

The papers (see Appendix) and additional results are summarized and discussed in the following sections. Papers I-IV are summarized in section 2.1-2.4, respectively and in section 2.5 the unpublished molecular modelling results are discussed.

\subsection{Synthesis and biological evaluation of PAC-1 analogues}

\subsubsection{Introduction}

Procaspase activating compound 1 (PAC-1, 12), was introduced as a direct activator of $p$ Casp-3 and suggested as a therapeutic agent against cancer. The initial biological and biochemical results implied that the allyl group and the proton donating effect of the molecule were responsible for the activity. Hence, we set forth to synthesize novel derivatives of $\mathbf{1 2}$ from products of the orthoformylation of phenols. In 2009 it was discovered that the activation of $p$ Casp-3 by PAC-1 (12) was zinc chelation dependent. Since zinc is important for many enzymes, among others enzymes involved in the cell cycle, there is a necessity to clarify the exact mechanisms of action. Therefore, we have investigated the effect of PAC-1 in a non-dividing cell type: cultured cerebellar granule neurons from chicken in addition to several cancer cell lines. 


\subsubsection{Synthesis and biological activities of PAC-1 derivatives}

Salicylaldehydes 105-116 were obtained by the previously described ortho-formylation reaction (Scheme 7).
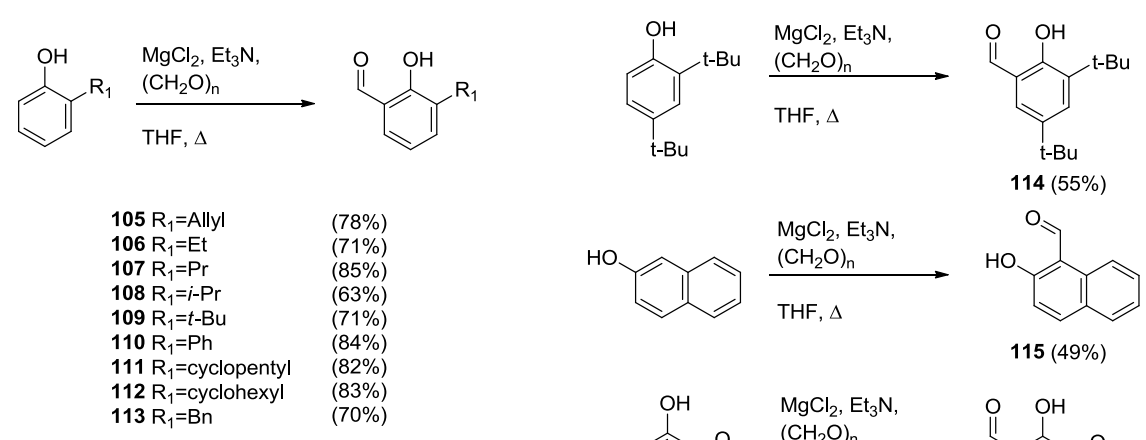

$115(49 \%)$
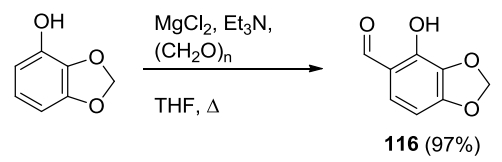

Scheme 7 ortho-Formylation of phenols.

Synthesis of hydrazide $\mathbf{1 2 0}$ was achieved with the same synthetic route as Hergenrother et al. and in comparable yields (Scheme 8). ${ }^{38}$ The hydrazide 120 was then condensed with salicylaldehydes to form the PAC-1 derivatives. In total, 16 PAC-1 derivatives were synthesized with overall yield between $23-67 \%$.
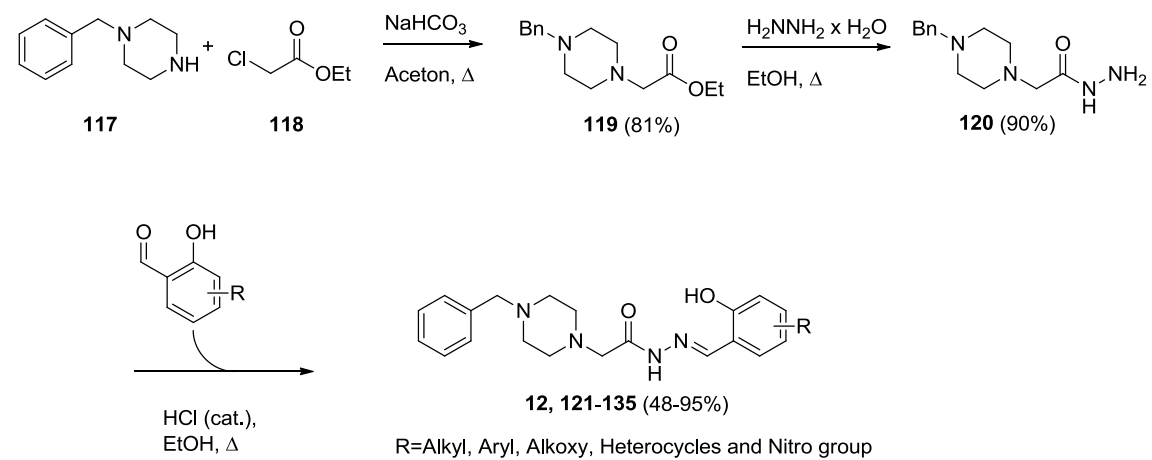

$12,121-135(48-95 \%)$

R=Alkyl, Aryl, Alkoxy, Heterocycles and Nitro group

Scheme 8 Synthesis of PAC-1 derivatives.

The derivatives synthesized were evaluated against seven cancer cell lines (MDA-MB231; SK-BR3; T47D; breast cancer cell lines, SKOV; OVCAR3; ovarian cancer cell lines, WM35; WM239; melanoma cancer cell lines) and cell proliferation was measured by $\left[{ }^{3} \mathrm{H}\right]$ thymidine incorporation (Table 4). ${ }^{229}$ According to Hergenrother and co-workers the $\mathrm{IC}_{50}$ values were related to the $p$ Casp-3 
concentration in each cell, therefore the $p$ Casp-3 concentrations in eight cancer cell lines were investigated with western blot (Figure 32). The concentration of $p$ Casp-3 in the melanoma cell lines were significantly higher compared to the other cell lines. The western blot showed that MDAMB231, SKBR-3, SKOV and OVCAR8 had low concentration of $p$ Casp-3. The PC12 and T46D cells had medium concentrations of $p$ Casp-3. To one well three times the amount of the T47D cell protein extracts was added to confirm a quantity dependent signal in the western-blot procedure.

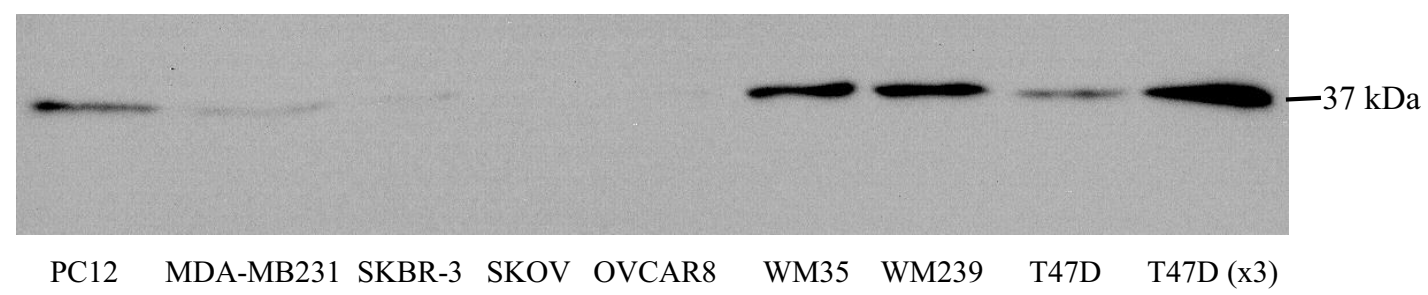

Figure 32 Western blot shows expression level of $p$ Casp-3 $(37 \mathrm{kDa})$ in eight cancer cell lines. To the two wells of T47D were added $15 \mu \mathrm{l}$ and $45 \mu \mathrm{l}$ cell protein extracts, respectively. The primary antibody was anti-caspase-3 (1:750, Cell Signalling). The secondary antibody was donkey anti-rabbit-hrp (Pierce). The blot was imaged with Bioimaging System (Syngene, Synoptics Ltd).

Table 4 Effects on viability of PAC-1 derivatives in seven cancer cell lines. Values are per cent of $\left[{ }^{3} \mathrm{H}\right]$ thymidine incorporation of vehicle treated control at a compound concentration of $5 \mu \mathrm{M}$.

\begin{tabular}{|c|c|c|c|c|c|c|c|c|c|}
\hline Compound & $\mathrm{R}_{1}$ & $\mathrm{R}_{2}$ & T47D & $\begin{array}{l}\text { MDA- } \\
\text { MB231 }\end{array}$ & SK-BR-3 & SKOV & OVCAR8 & WM35 & WM239 \\
\hline PAC-1 (12) & Allyl & $\mathrm{H}$ & $11 \%$ & $22 \%$ & $7 \%$ & $19 \%$ & $28 \%$ & $5 \%$ & $27 \%$ \\
\hline 121 & Ethyl & $\mathrm{H}$ & $13 \%$ & $8 \%$ & $17 \%$ & $11 \%$ & $19 \%$ & $1 \%$ & $1 \%$ \\
\hline 122 & Propyl & $\mathrm{H}$ & $13 \%$ & $16 \%$ & $4 \%$ & $27 \%$ & $28 \%$ & $3 \%$ & $1 \%$ \\
\hline 123 & $i$-Propyl & $\mathrm{H}$ & $13 \%$ & $14 \%$ & $26 \%$ & $16 \%$ & $21 \%$ & $5 \%$ & $10 \%$ \\
\hline 124 & $t$-Butyl & $\mathrm{H}$ & $21 \%$ & $26 \%$ & $15 \%$ & $26 \%$ & $23 \%$ & $9 \%$ & $8 \%$ \\
\hline 125 & Phenyl & $\mathrm{H}$ & $12 \%$ & $19 \%$ & $4 \%$ & $32 \%$ & $11 \%$ & $4 \%$ & $2 \%$ \\
\hline 126 & Cyclopenthyl & $\mathrm{H}$ & $10 \%$ & $16 \%$ & $9 \%$ & $6 \%$ & $10 \%$ & $1 \%$ & $1 \%$ \\
\hline 127 & Cyclohexyl & $\mathrm{H}$ & $6 \%$ & $11 \%$ & $4 \%$ & $14 \%$ & $15 \%$ & $2 \%$ & $3 \%$ \\
\hline 128 & Benzyl & $\mathrm{H}$ & $6 \%$ & $14 \%$ & $2 \%$ & $13 \%$ & $11 \%$ & $1 \%$ & $1 \%$ \\
\hline 129 & Ethoxy & $\mathrm{H}$ & $68 \%$ & $36 \%$ & $82 \%$ & $37 \%$ & $37 \%$ & $5 \%$ & $19 \%$ \\
\hline 130 & $t$-Butyl & $t$-Butyl & $9 \%$ & $10 \%$ & $8 \%$ & $2 \%$ & $12 \%$ & $1 \%$ & $0 \%$ \\
\hline 131 & Nitro & $\mathrm{H}$ & $85 \%$ & $102 \%$ & $136 \%$ & $96 \%$ & $79 \%$ & $66 \%$ & $78 \%$ \\
\hline
\end{tabular}




\begin{tabular}{|c|c|c|c|c|c|c|c|c|}
\hline Compound & $\mathrm{R}$ & T47D & $\begin{array}{l}\text { MDA- } \\
\text { MB231 }\end{array}$ & SK-BR-3 & SKOV & OVCAR8 & WM35 & WM239 \\
\hline 132 & & $55 \%$ & $73 \%$ & $59 \%$ & $22 \%$ & $39 \%$ & $1 \%$ & $10 \%$ \\
\hline 133 & & $91 \%$ & $94 \%$ & $87 \%$ & $94 \%$ & $86 \%$ & $106 \%$ & $85 \%$ \\
\hline 134 & & $34 \%$ & $21 \%$ & $29 \%$ & $46 \%$ & $47 \%$ & $40 \%$ & $43 \%$ \\
\hline 135 & & $70 \%$ & $37 \%$ & $67 \%$ & $22 \%$ & $23 \%$ & $8 \%$ & $18 \%$ \\
\hline
\end{tabular}

In general, compounds 121-130, 132 and 135 were equally or more anti-proliferating than PAC-1 against the melanoma cell lines WM35 and WM239 (Table 4). The activity was in agreement with the amount of $p$ Casp- 3 found in the cells. The proliferating activity in the cells lines with highest $p$ Casp-3 concentration were most affected by treatment with PAC-1 derivatives. The Hergenrother group discovered that the procaspase activating properties of PAC-1 was due to zinc chelation by the salicylaldehyde semicarbazone moiety (Section 1.3.3, Figure 5). ${ }^{46,47}$ The UV-Vis spectra of PAC-1 is depicted in Figure 33. There is a clear decrease in absorption at $\sim 280 \mathrm{~nm}$ and an increase at $410 \mathrm{~nm}$ which indicated that $\mathrm{Zn}^{2+}$ influenced the conjugated $\pi$-electrons of PAC-1.

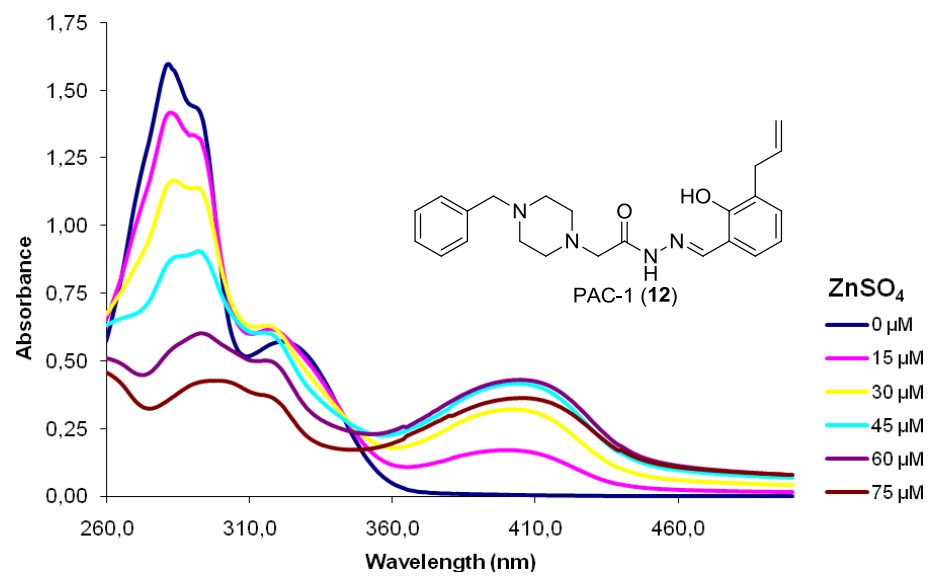

Figure 33 PAC-1 chelates zinc. $50 \mu \mathrm{M}$ PAC-1 treated with increasing concentrations of added $\mathrm{ZnSO}_{4}$. 
Compound 131 lack of activity may be assign to the electron withdrawing properties or an intramolecular hydrogen bond to the phenol by the nitro substituent. In hindsight, it is logical that compounds 133 and $\mathbf{1 3 4}$ were less active as the phenolic moieties are alkylated and unavailable for zinc chelation. The naphthalene derivative 132 and compounds 129 and 135 were poor proliferating inhibitors in the cell lines except the melanoma cell lines. The benzyl 128 and di-t-butyl 130 derivatives inhibited $\left[{ }^{3} \mathrm{H}\right]$ thymidine incorporation with at least $86 \%$ in all the cell lines, and were the most potent anti-proliferating derivatives tested.

Compounds 128 and 130 were further evaluated for cytotoxic activity in the PC12 cell line. The $\mathrm{IC}_{50}$ values of PAC-1 (12), measured by MTT, were not significantly different in PC12 cells between 48 or 72 hours. In the PC12 cell line the compounds 12, 128 and 130 showed similar trends in activity, but roughly a tenfold difference in activity between the $\left[{ }^{3} \mathrm{H}\right]$ thymidine and MTT assay values was observed (Figure 34). An explanation might be that $\left[{ }^{3} \mathrm{H}\right]$ thymidine incorporation measures the cells proliferating activity and the MTT assay measures cell viability. This indicates that PAC-1 and the derivatives were cytostatic at approximately one tenth of the cytotoxic concentration.
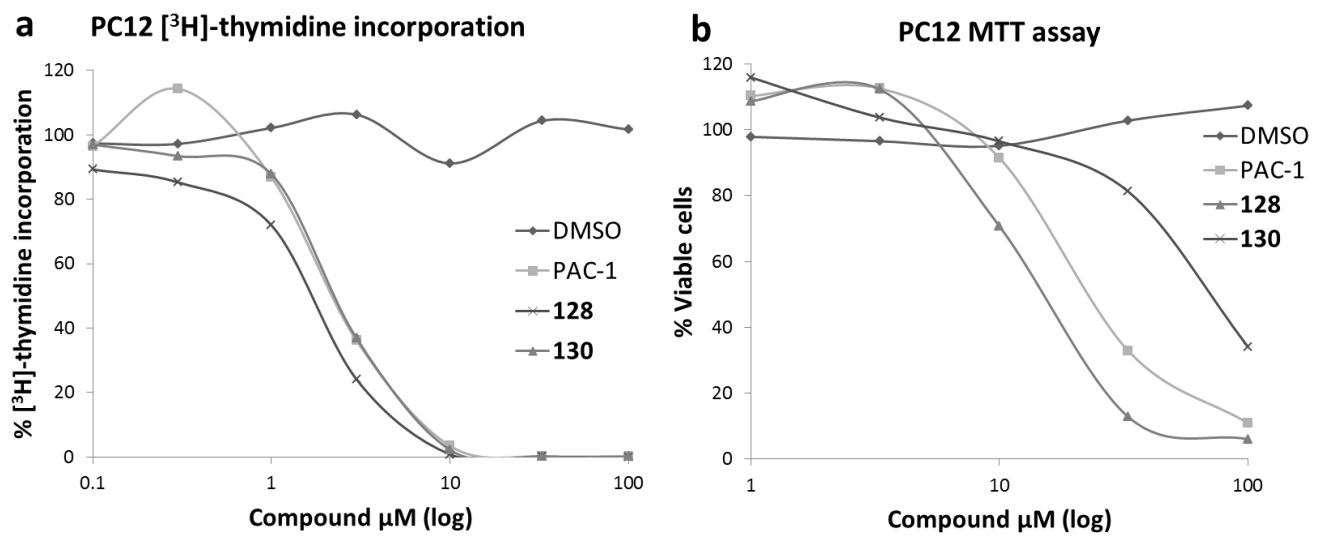

Figure 34 Plot of PC12 cell viability against concentration of compounds PAC-1 (12), 128 and 130. Values are average of 6 independent measurements. (a) $\left.{ }^{3} \mathrm{H}\right]$ Thymidine incorporation, $\mathrm{t}=72 \mathrm{~h}$. (b) MTT assay, $\mathrm{t}=48 \mathrm{~h}$.

High concentrations of compound $\mathbf{1 3 0}$ was poorly soluble in the PC12 medium, probably as a result of its high lipophilic property $(\operatorname{cog} P=5.79)$. One might speculate how this influences the activity in the MTT assay, from the data presented in Figure 34b, 130 was less cytotoxic than 12 and 128. Crystal formation was observed in the medium when $100 \mu \mathrm{M}$ PAC-1 was added. This indicates that the concentration could have been lower than estimated.

Cytotoxic activity of $100 \mu \mathrm{M}$ PAC-1 or $\mathbf{1 2 8}$ was not inhibited when cells were pretreated with EGF 
(Figure 35a). When pretreated with NGF slightly more viable cells were observed in the PAC-1 (12) treated cells (Figure 35b). The caspase-3 inhibitor Ac-DEVD-cmk (Figure 35c) or pancaspase inhibitor Boc-D-fmk (Figure 35d) had little effect on cell death for PC12 cells treated with PAC-1 (12) or 128, indicating that the contribution of caspases in cell death is minor. These findings have been confirmed by others. ${ }^{230,231}$ In neurones however, Ac-DEVD-cmk protected significantly against 12 induced cell death. This indicates that PAC-1 (12) induces cell death by other mechanisms in PC12 cells.
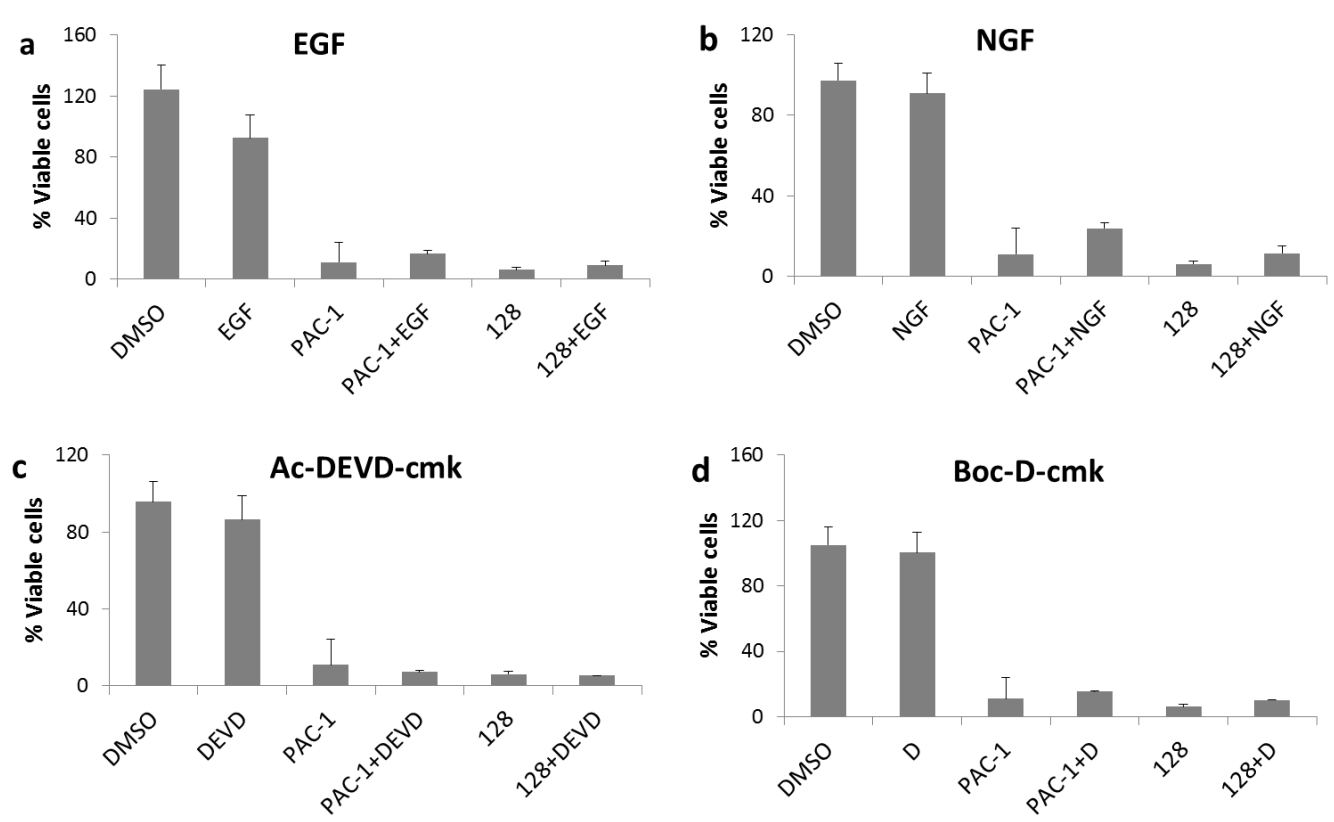

Figure 35 Influence of inhibitors and growth factors on cell viability in combination with $100 \mu \mathrm{M}$ PAC-1 (12) or 100 $\mu \mathrm{M}$ compound 128 measured by MTT assay. The concentrations used were EGF $5 \mathrm{ng} / \mathrm{ml}$, NGF $50 \mathrm{ng} / \mathrm{ml}$, Ac-DEVDcmk $(1 \mu \mathrm{M})$ and Boc-D-fmk $(10 \mu \mathrm{M})$. The experiments were performed as three individual experiments in duplicates.

\subsubsection{Conclusions}

By using the ortho-formylation reaction 16 PAC-1 derivatives were synthesized and evaluated for anti-proliferating activities against seven cell lines. Most of the derivatives inhibited proliferation equally or better than $\mathbf{1 2}$ in the melanoma cell lines WM35 and WM239. Analogues 128 and 130 had comparable activity to PAC- 1 in the PC12 cell line measured by [ $\left.{ }^{3} \mathrm{H}\right]$ thymidine incorporation or MTT assay. The cytotoxicity of PAC-1 and compound $\mathbf{1 2 8}$ in the PC12 cells were not influenced by addition of EGF or NGF at the concentration tested. Inhibitors Ac-DEVD-cmk and Boc-D-cmk 
could not prevent PAC-1 (12) or 128 induced cell death at a compound concentration of $100 \mu \mathrm{M}$.

\section{2 ortho-Formylation of oxygenated phenols}

The reported regioselective ortho-formylation reaction of substituted phenols using the $\mathrm{MgCl}_{2}-\mathrm{Et}_{3} \mathrm{~N}$ base system and paraformaldehyde affords salicylaldehydes in excellent yields. ${ }^{170,171}$ The salicylaldehydes obtained by this method have been employed by us and others for the preparation of useful products and intermediates. We wanted to extend this methodology to substituted monoprotected resorcinols, a structural feature found in many natural products and biologically active substances. ${ }^{232-238}$ As a part of the initial hypothesis that the compound $\mathbf{1 2}$ was a proton donor to the triaspartic safety catch of $p$ Casp-3, resorcinols aldehydes were thought of as potential building blocks for the condensation with the hydrazide $\mathbf{1 2 0}$ evolving into a compound with two available protons, hence twice the potential activity (Figure 36).

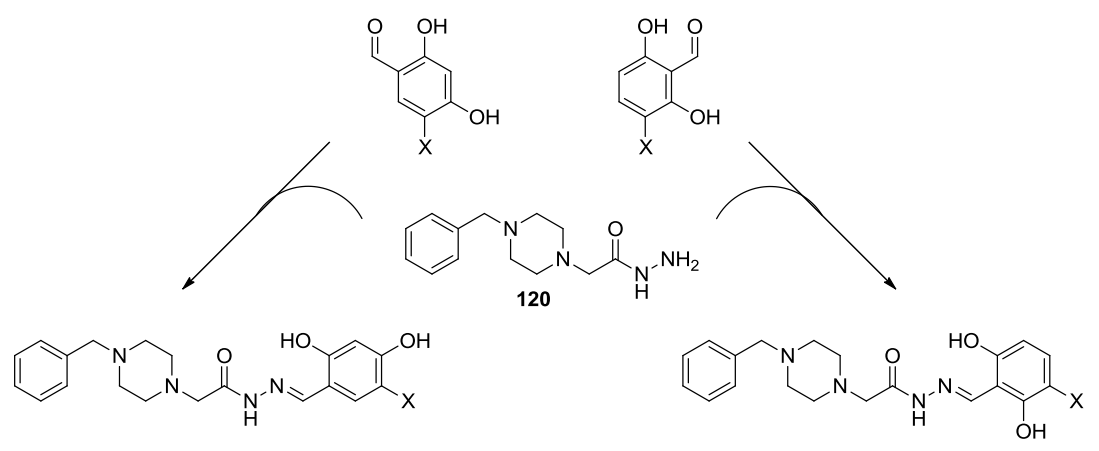

$\mathrm{X}=\mathrm{H}, \mathrm{Cl}, \mathrm{Br}$

Figure 36 Synthesis of resorcinol analogues of PAC-1.

A second objective was to explore the regioselectivity of the ortho-formylation reaction on monoprotected resorcinols. ortho-Formylation of resorcinol, catechol, pyrogallol or phloroglucinol with the $\mathrm{MgCl}_{2} / \mathrm{Et}_{3} \mathrm{~N}$ base system resulted in polymerization. Resorcinols were protected under standard procedures and the di- and mono-protected derivatives were separated by chromatography. The results are summarized in Table 5 and Table 6. ortho-Formylation of the pivalate 137a and tertbutylcarbonate 138a protected resorcinols resulted in a mixture of products. The C-6 formylated products, 137c and 138c, were the minor component. Though not investigated, the reaction conditions could be responsible for hydrolysing the esters/carbonate of compounds $\mathbf{1 3 6} \mathbf{b}-\mathbf{1 3 8 b}$, resulting in low yields of the mono-protected compound. The TMS and TES mono ethers of resorcinol were unstable and did not provide any formylated products. The mono TBDMS ether of 
catechol was not either formylated. The di-protected phloroglucinols $154 \mathbf{b} / \mathbf{c}$ and $155 \mathrm{~b} / \mathbf{c}$ were obtained in low yields and the C-2 and C-6 formyl mixtures were inseparable by chromatography. Based on ${ }^{1} \mathrm{H}-\mathrm{NMR}$ analysis of the product mixture; the ratio of $\mathbf{1 5 5 b}$ and $\mathbf{1 5 5 c}$ were approximately 1:1. The products of the ortho-formylation of TBDMS protected phloroglucinol 156a were formed in a 3:1 ratio.

Table 5 Results of ortho-formylation of mono-protected resorcinols.

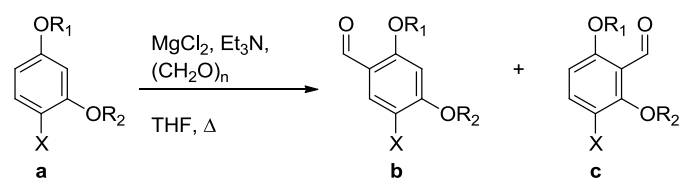

\begin{tabular}{ccccccc} 
Entry & Compound & $\mathrm{R}_{1}$ & $\mathrm{R}_{2}$ & $\mathrm{X}$ & Yield b & Yield c \\
\hline 1 & 136a & $\mathrm{H}$ & $\mathrm{Ac}$ & $\mathrm{H}$ & $20 \%$ & - \\
2 & $\mathbf{1 3 7 a}$ & $\mathrm{H}$ & $\mathrm{Piv}$ & $\mathrm{H}$ & $39 \%$ & $2 \%^{\mathrm{b}}$ \\
3 & $\mathbf{1 3 8 a}$ & $\mathrm{H}$ & $\mathrm{Boc}$ & $\mathrm{H}$ & $30 \%$ & $2 \%^{\mathrm{b}}$ \\
4 & $\mathbf{1 3 9 a}$ & $\mathrm{H}$ & Thexyldimethylsilyl & $\mathrm{H}$ & $88 \%$ & - \\
5 & $\mathbf{1 4 0 a}$ & $\mathrm{H}$ & $\mathrm{Me}$ & $\mathrm{H}$ & $92 \%$ & $5 \%$ \\
6 & $\mathbf{1 4 1 a}$ & $\mathrm{H}$ & $\mathrm{Bn}$ & $\mathrm{H}$ & $88 \%$ & - \\
7 & $\mathbf{1 4 2 a}$ & $\mathrm{H}$ & $\mathrm{TBDMS}$ & $\mathrm{H}$ & $80 \%$ & - \\
8 & $\mathbf{1 4 3 a}$ & $\mathrm{H}$ & $\mathrm{Me}$ & $\mathrm{Cl}$ & $94 \%$ & - \\
9 & $\mathbf{1 4 4 a}$ & $\mathrm{H}$ & $\mathrm{Bn}$ & $\mathrm{Cl}$ & $85 \%$ & - \\
10 & $\mathbf{1 4 5 a}$ & $\mathrm{H}$ & $\mathrm{TBDMS}$ & $\mathrm{Cl}$ & $60 \%$ & - \\
11 & $\mathbf{1 4 6 a}$ & $\mathrm{TBDMS}$ & $\mathrm{H}$ & $\mathrm{Cl}$ & - & $73 \%$ \\
12 & $\mathbf{1 4 7 a}$ & $\mathrm{H}$ & $\mathrm{Me}$ & $\mathrm{Br}$ & $90 \%$ & - \\
13 & $\mathbf{1 4 8 a}$ & $\mathrm{H}$ & $\mathrm{TBDMS}$ & $\mathrm{Br}$ & $73 \%$ & - \\
14 & $\mathbf{1 4 9 a}$ & $\mathrm{TBDMS}$ & $\mathrm{H}$ & $\mathrm{Br}$ & - & $85 \%$ \\
\hline
\end{tabular}


Table 6 Results from ortho-formylation of protected catecholes and phloroglucinols.
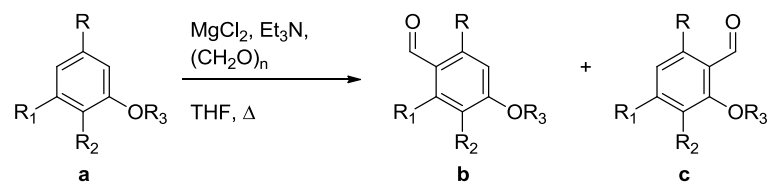

\begin{tabular}{cccccccc} 
Entry & Compound & $\mathrm{R}$ & $\mathrm{R}_{1}$ & $\mathrm{R}_{2}$ & $\mathrm{R}_{3}$ & Yield b & Yield c \\
\hline 1 & $\mathbf{1 5 0 a}$ & $\mathrm{H}$ & $\mathrm{OH}$ & $\mathrm{OMe}$ & $\mathrm{Me}$ & $11 \%$ & - \\
2 & $\mathbf{1 5 1 a}$ & $\mathrm{H}$ & $\mathrm{OH}$ & $-\mathrm{OCH}_{2-}$ & $97 \%$ & - \\
3 & $\mathbf{1 5 2 a}$ & $\mathrm{OH}$ & $\mathrm{H}$ & $-\mathrm{OCH}_{2-}$ & $45 \%$ & - \\
4 & $\mathbf{1 5 3 a}$ & $\mathrm{H}$ & $\mathrm{OH}$ & $-\mathrm{OC}^{-}\left(\mathrm{CH}_{3}\right)_{2}-$ & $82 \%$ & - \\
5 & $\mathbf{1 5 4 a}$ & $\mathrm{OH}$ & $\mathrm{OMe}$ & $\mathrm{H}$ & $\mathrm{TBDMS}^{-}$ & $20 \%$ \\
6 & $\mathbf{1 5 5 a}$ & $\mathrm{OH}$ & $\mathrm{OMe}$ & $\mathrm{H}$ & $\mathrm{Bn}$ & \multicolumn{2}{c}{$30 \%$} \\
7 & $\mathbf{1 5 6 a}$ & $\mathrm{OH}$ & $\mathrm{OMe}$ & $\mathrm{H}$ & $\mathrm{Me}$ & \multicolumn{2}{c}{$21 \%$} \\
\hline
\end{tabular}
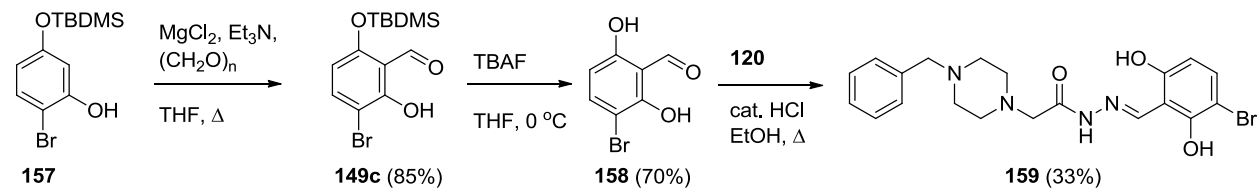

Scheme 9 The synthesis of compound 159.

To finalize the initial prospect for the ortho-formylation of resorcinols; two PAC-1 derivatives were synthesized. The compound 135 was synthesized from $151 \mathbf{b}$ and is found in section 2.1.2. Desilylation of compound 149c proceeded cleanly with $\mathrm{TBAF}$ at $0{ }^{\circ} \mathrm{C}$ in $\mathrm{THF}$, and yielded compound 158 (70\%) (Scheme 9). The product was condensed under standard conditions with hydrazide 120 to PAC-1 derivative $\mathbf{1 5 9}$ in 33\% yield.

\subsubsection{Conclusions}

In conclusion, we have extended the experimentally simple and regioselective ortho-formylation protocol to mono protected resorcinols and methylenedioxy substituted phenols. The formylations proceeded with high to excellent yields and regioselectivity. Two of the synthesized aldehydes were condensed with hydrazide $\mathbf{1 2 0}$ to form PAC-1 derivatives 135 and $\mathbf{1 5 9}$. 


\section{3 ortho-Formylation of estrogens and synthesis of 2- methoxyestradiol}

\subsection{1 ortho-Formylation of estrogens}

Functionalization of organic compounds is an important chemical formation often necessary for the synthesis of analogues. Aldehydes are such functional handles, and they can be added to aromatic compounds by several efficient formylation methods (see section 1.7.1). ${ }^{156-159}$ Estrogens are a class of compounds that could benefit from such a functional group addition. A protocol for selective ortho-formylation of phenols using benign conditions and reagents was described by Skattebøl and Hofsløkken. ${ }^{170,174}$ An unaddressed issue is the regioselectivity when dealing with meta-substituted phenols.

The A-ring of estrogens could be considered as meta- and para-substituted phenol, an intriguing predicament for selectivity of the ortho-formylation reaction. Therefore several commercially available and synthesized estrogens were subjected to the reaction conditions. The results are summarized in Table 7. The regioisomeric ratio was determined by LC/MS and ${ }^{1} \mathrm{H}-\mathrm{NMR}$ analyses. All estrogens were formylated in good yields except estriol (163). The acetal 164 was hydrolyzed during work up of the reaction mixture and the 2- and 4-formyl estrone, 101 and 102, were found in the crude mixture. 
Table 7 ortho-Formylation of estrogens.

\begin{tabular}{|c|c|c|c|c|c|}
\hline Estrogen & $\mathrm{R}_{1}$ & $\mathrm{R}_{2}$ & $\mathrm{R}_{3}$ & $\begin{array}{c}\text { Regioisomeric ratio } \\
(\mathbf{a}: \mathbf{b})^{\mathrm{a}}\end{array}$ & Yield $\%{ }^{b}$ \\
\hline 84 & $\mathrm{OH}$ & $\mathrm{H}$ & $\mathrm{H}$ & $13: 1$ & 92 \\
\hline 99 & $\mathrm{OH}$ & $\mathrm{CCH}$ & $\mathrm{H}$ & $6: 1$ & 86 \\
\hline 160 & $\mathrm{OH}$ & $\mathrm{CH}_{2} \mathrm{CH}_{3}$ & $\mathrm{H}$ & 12:1 & 90 \\
\hline 161 & $\mathrm{H}$ & $\mathrm{OH}$ & $\mathrm{H}$ & 13:1 & 85 \\
\hline 162 & OAc & $\mathrm{H}$ & $\mathrm{H}$ & $8: 1$ & 90 \\
\hline 163 & $\mathrm{OH}$ & $\mathrm{H}$ & $\mathrm{OH}$ & n.d. ${ }^{\mathrm{c}}$ & 15 \\
\hline 88 & $=\mathrm{O}$ & \multicolumn{2}{|c|}{$\mathrm{H}$} & $9: 1$ & 90 \\
\hline 164 & $\mathrm{OCH}_{2} \mathrm{CH}_{2} \mathrm{O}$ & \multicolumn{2}{|c|}{$\mathrm{H}$} & $12: 1$ & $74^{\mathrm{d}}$ \\
\hline
\end{tabular}

${ }^{\mathrm{a}}$ The regioisomeric ratios of the salicylaldehydes were determined by LC/MS analysis.

${ }^{\mathrm{b}}$ The yields and regioisomeric ratios are based on three experiments. The regioisomeric ratios were constant in all experiments.

${ }^{\mathrm{c}}$ Not determined.

${ }^{\mathrm{d}}$ A 12:1 regioisomeric mixture of $\mathbf{1 0 1}$ and $\mathbf{1 0 2}$ was also obtained in 14\% isolated yield.

Several of the reaction reagents were investigated on estradiol (84). Replacing the solvent with DCM, dioxane, toluene, DMF or ACN gave no or poor yields. This was surprising as both ACN and DCM have been successfully employed by others in combination with these reagents. ${ }^{170,208}$ THF was, under these conditions, the superior solvent tested for this transformation on $\mathbf{8 4}$.

In the same ortho-formylation reaction conditions with estradiol, triethylamine was exchanged with diazabicyclo [5.4.0] undec-7-ene (DBU), 4-dimethylaminopyridine (DMAP), diisopropylethylamine (DIPEA), diisopropylamine, piperidine or dimethylethylamine. All liquid bases were distilled prior to use and kept over $3 \AA$ molecular sieve. Unfortunately, none of the bases were able to fully convert estradiol to $\mathbf{9 4}$ and $\mathbf{9 5}$. In all reaction mixtures estradiol was found in quantities of $25-60 \%$, quantified by ${ }^{1} \mathrm{H}-\mathrm{NMR}$ analyses. The regioisomeric ratio varied from $2: 1$ to $5: 1$, all inferior to triethylamine in regards of selectivity towards compound $\mathbf{9 4 .}$

Furthermore, divalent inorganic salts were investigated for their influence over the orthoformylation regioselectivity and yield. Anhydrous magnesium iodide, magnesium bromide, zinc chloride, copper chloride, calcium chloride and non-anhydrous quality of magnesium bromide were tested. All the salts are hydroscopic, and the magnesium and zinc salts are even deliquescent. The anhydrous zinc and magnesium chloride salts are unobtainable from their hydrates by simple 
heating as this result in the production of oxychlorides and liberation of hydrochloric acid. The anhydrous salt can be prepared in the laboratory, but requires sublimation of the salt by strong heating $\left(700^{\circ} \mathrm{C}\right)$ under the corresponding hydrohalogen acid atmosphere. ${ }^{239,240}$

Copper chloride and calcium chloride were not reactive under the reaction conditions employed. The anhydrous magnesium iodide and the non-anhydrous quality of magnesium bromide were less reactive than anhydrous magnesium bromide, both leaving $60 \%$ unreacted estradiol while the latter left 40\% unreacted estradiol, respectively. The regioisomeric ratios (94:95) were in-between 7:1 and 11:1, none-anhydrous magnesium bromide the least and zinc chloride was the most selective.

\subsubsection{Synthesis of 2-methoxyestradiol}

2-Methoxyestradiol (85) was synthesized one year before it was identified as a natural metabolite in 1959. ${ }^{121,241}$ Forty years later the tubulin inhibition properties of $\mathbf{8 5}$ were discovered and set forth a crusade for an efficient synthesis (see section 1.5). ${ }^{115}$ It was also discovered to be an inhibitor of angiogenesis. ${ }^{116-118}$

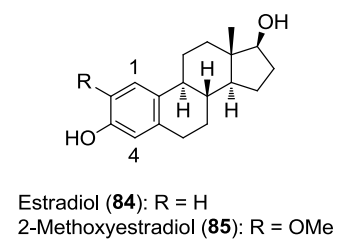

Figure 37 Structure of estradiol and 2-methoxyestradiol.

Our approach to the total synthesis of $2 \mathrm{ME} 2$ was identical to that of others, except for employing the ortho-formylation reaction using $\mathrm{MgCl}_{2} / \mathrm{Et}_{3} \mathrm{~N}$ and paraformaldehyde for installing the initial 2formyl group (Scheme 10). ${ }^{129}$ Estradiol (84) was formylated with the described method resulting in a 13:1 mixture of 94 and 95 but was also contaminated with $\sim 10 \%$ of the $17 \beta$-formate (96). The reaction mixture was hydrolyzed with $2 \mathrm{M} \mathrm{LiOH}$ in methanol before the 3- and 17ß-hydroxyl groups were protected as bis(MOM) ethers. The two regioisomers were separated by chromatography and the 2-fromyl bis(MOM) ether 166 was isolated in 60\% yield over the course of three steps. The four following steps provided $\mathbf{8 5}$ in $36 \%$ overall yield. 


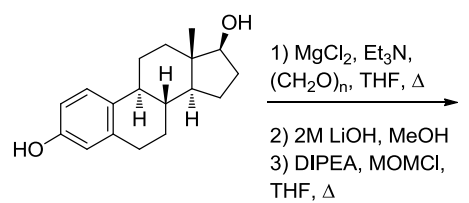

84

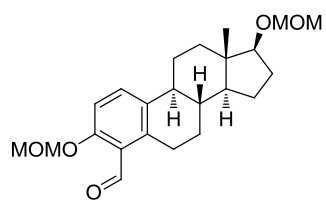

165

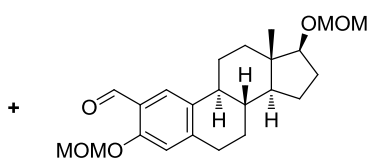

166 (60\% over three steps)

1) $m$-CPBA, $\mathrm{Na}_{2} \mathrm{HPO}_{4}, \mathrm{DCM}$ 2) $1 \mathrm{M} \mathrm{NaOH}, \mathrm{MeOH}$

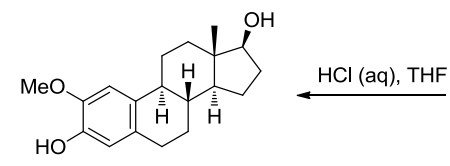

2-Methoxyestradiol (85) (82\%)

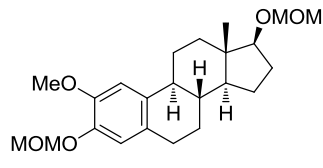

$168(85 \%)$ $\frac{\mathrm{Mel}, \mathrm{K}_{2} \mathrm{CO}_{3}, \mathrm{Bu}_{4} \mathrm{NI}}{\text { DMF }}$

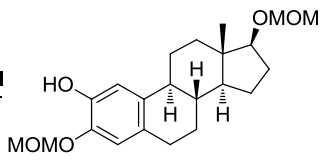

$167(86 \%)$

Scheme 10 Synthetic route to 2ME2.

\subsubsection{Conclusions}

In conclusion, the experimentally simple and regioselective ortho-formylation protocol of phenols was extended to several estrogens. All but one of the formylations occurred with high to excellent yields. In all cases, formation of the 2-isomer was highly preferred. Our studies indicate that the ortho-formylation of estradiol was sensitive to variations in base, salt or solvent used. The orthoformylation reaction was successfully applied to the total synthesis of $2 \mathrm{ME} 2$, which gave the final compound in an overall yield of $36 \%$. This synthesis compares favourably to other syntheses published, especially with respect to yield and simplicity.

\subsection{Synthesis and biological evaluation of combretastatin A-1 analogues}

Combretastatin A-1 (19) has attracted interest as a lead compound due to its anti-cancer properties (see section 1.4), but received less attention than CA-4 (20). The poor aqueous solubility of CA-1 was improved by the synthesis of its phosphate prodrug. ${ }^{77}$ The phosphate prodrug of CA-1 (21) is a more potent VDA than CA-4P (22), and is currently in a phase I clinical trial. Potential energy surface calculation indicates that CA-1 cis-configuration is favoured. ${ }^{242}$ The importance of retaining a cis-configuration has been confirmed by SAR studies on CA-4 and CA-1. As mentioned, the trans-isomers of CA-1 and CA-4 are inactive in biological assays. ${ }^{74,98,99}$ 


\subsubsection{Synthesis of 1,4- and 1,5-disubstituted 1,2,3-triazole analogues of CA-1}

Structure activity relationship studies of CA-1 (19) and CA-4 (20) have shown that a 3,4,5-trimethoxy substituted A-ring and a 4'-methoxy substituted B-ring separated by a double bond with cis-configuration are important for optimal cytotoxic activity. This prompted us to prepare a series of cis-restricted analogues of $\mathbf{1 9}$ by replacing the olefinic bridge with a 1,5-disubstituted1,2,3-triazole. Our aim was to improve the anti-cancer activities and water solubility compared to CA-1 (19). The olefinic bridge of 20 has been successfully replaced by 1,5-disubstituted-1,2,3triazole in our lab and others. ${ }^{229,243-246}$

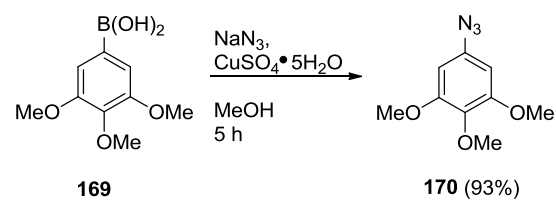

Scheme 11 Synthesis of azide $\mathbf{1 7 0 .}$

Preparation of azide 170 was achieved from the boronic acid 169 in reaction with copper sulphate and sodium azide as previously reported. ${ }^{243}$ The azide was used without further purification after work up. ${ }^{247}$
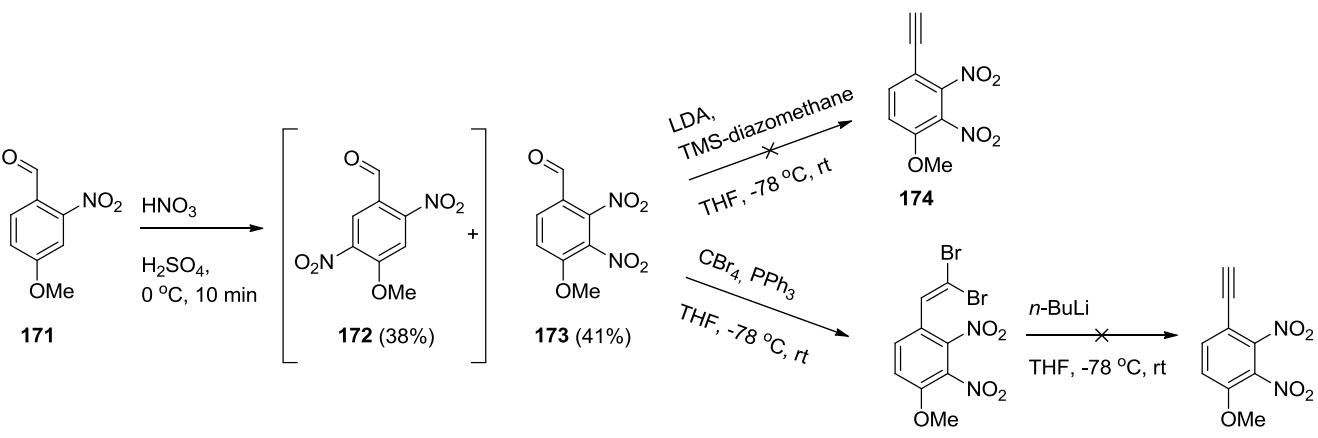

174

Scheme 12 Nitration of 4-methoxy-2-nitro-benzealdehyde. Attempted synthesis of $\mathbf{1 7 4}$ by the Colvin rearrangement and the Corey-Fuchs reaction method.

For the synthesis of the dinitro compound 173, 4-methoxy-2-nitro-benzealdehyde (171) was treated with nitric acid in fuming sulphuric acid (Scheme 12). ${ }^{105}$ An approximately 1:1 mixture of the 2,3and 2,5-dinitro benzadehydes, 172 and 173, were isolated. Roughly $10 \%$ of the aldehydes were oxidized to the benzoic acid observed by ${ }^{1} \mathrm{H}$ - and ${ }^{13} \mathrm{C}-\mathrm{NMR}$ analyses. The aldehyde and acid had 
identical retention factor $\left(\mathrm{R}_{\mathrm{f}}\right)$ on normal phase TLC and were inseparable by chromatography or acid/base extraction. The aldehyde/acid mixture was used in the preparation of the alkyne $\mathbf{1 7 4}$. Neither the Colvin rearrangement nor the Corey-Fuchs method was able to produce the desired alkyne from the aforementioned mixture. ${ }^{248,249}$ The experiments indicated that the dinitro moiety was incompatible with strong base (Scheme 12). Fortunately, the mild and practical method of Ohira-Bestmann completed the task. ${ }^{250-252}$ The aldehyde/acid mixture of $\mathbf{1 7 3}$ was reacted with the reagent 175 at $0{ }^{\circ} \mathrm{C}$ in the presence of potassium carbonate in methanol to produce the corresponding alkyne 174 (Scheme 13).
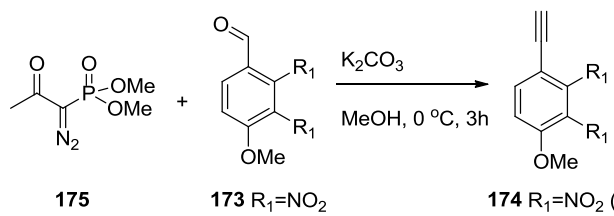

$$
\begin{array}{ll}
173 \mathrm{R}_{1}=\mathrm{NO}_{2} & 174 \mathrm{R}_{1}=\mathrm{NO}_{2}(75 \%) \\
176 \mathrm{R}_{1}=\mathrm{F} & 177 \mathrm{R}_{1}=\mathrm{F} \quad(>85 \%)
\end{array}
$$

Scheme 13 Syntheses of compounds 174 and 177 with the Ohira-Bestmann reagent.

Ph.D. student Kristin Odlo synthesized 1-ethynyl-2,3-difluoro-4-methoxybenzene (177) in 43\% yield by the means of the Colvin rearrangement. ${ }^{113}$ An improved synthesis for $\mathbf{1 7 7}$ was desired and the corresponding aldehyde $\mathbf{1 7 6}$ was subjected to the Ohira-Bestmann conditions (Scheme 13). The alkyne 177 was analytically pure after work up of the reaction mixture, and was obtained in more than $85 \%$ yield after chromatography. It should be mentioned that the 2,3-difluoro alkyne 177 was volatile and sublimated in vacuum at room temperature.

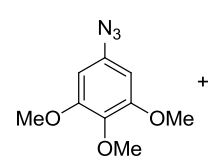

170

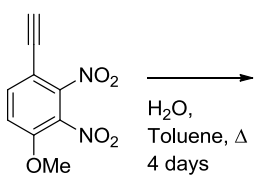

174<smiles>COc1cc(-n2nncc2-c2ccc(OC)c([N+](=O)[O-])c2[N+](=O)[O-])cc(OC)c1OC</smiles>

$178(43 \%)$

Separated by chromatography

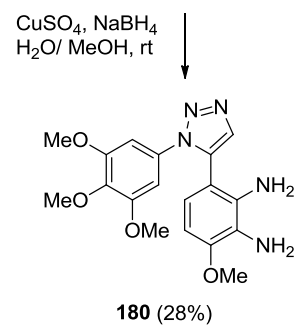

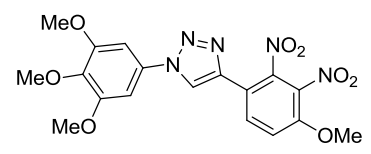

$179(45 \%)$

$\mid \begin{aligned} & \mathrm{CuSO}_{4}, \mathrm{NaBH}_{4} \\ & \mathrm{H}_{2} \mathrm{O} / \mathrm{MeOH}, \mathrm{rt}\end{aligned}$<smiles>COc1ccc(-c2cn(-c3cc(OC)c(OC)c(OC)c3)nn2)c(N)c1N</smiles>

$181(19 \%)$

Scheme 14 Synthesis of 1,2,3-triazole CA-1 analogues 178-181. 
The 1,2,3-triazoles $\mathbf{1 7 8}$ and $\mathbf{1 7 9}$ were synthesised by a thermal Husigen 1,3-dipolar cycloaddition (Scheme 14). Azide 170 was reacted with alkyne 174 in refluxing 1:1 (v/v) toluene/water for four days. The reaction was monitored by TLC and did not proceed to completion even after two weeks of reaction time. The thermal Husigen 1,3-dipolar cycloaddition afforded 1,5- and 1,4-disubstituted 1,2,3-triazoles, 178 and $\mathbf{1 7 9}$ in high yields and roughly 1:1 mixture. The dinitro compounds were synthesized as intermediates to the desired diamine 1,2,3-triazoles $\mathbf{1 8 0}$ and 181. Combretastatin A-1 and A-4 analogues have in general been equal or more active when substituting hydroxyl groups with amines. ${ }^{102,105,229,244,253,254}$ Siles and co-workers applied zinc dust in acetic acid for the reduction of vicinal nitro groups for the synthesis of a diamino analogue of CA-1 (59). When compound 178 was submitted to the same reducing conditions, a complex reaction mixture was obtained. Reduction with hydrogen (1 atm.) over $\mathrm{Pd} / \mathrm{C}$ in methanol was not successful. Following the protocol of Yoo and co-workers, the nitro groups were reduced with $\mathrm{NaBH}_{4}$ and $\mathrm{CuSO}_{4} \cdot 5 \mathrm{H}_{2} \mathrm{O}$ in methanol, which afforded the compounds 180 and 181. Unfortunately only poor yields were obtained. $^{255}$
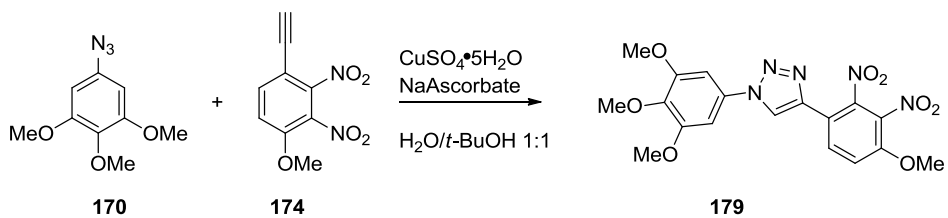

Scheme 15 CuAAC synthesis of 179.

For a selective synthesis of 1,4-disubstituted 1,2,3-triazole 179, the CuAAC reaction conditions were applied to azide $\mathbf{1 7 0}$ and alkyne 174. Initially, the standard conditions with $\mathrm{CuSO}_{4} \cdot 5 \mathrm{H}_{2} \mathrm{O}(0.1$ mol/eqv.) and sodium ascorbate $(0.05 \mathrm{~mol} / \mathrm{eqv}$.) in water $/ \mathrm{t}-\mathrm{BuOH}$ were employed at room temperature. After 24 hours, no formation of the product was observed by TLC analysis. Increasing the temperature to $45^{\circ} \mathrm{C}$ did not accelerate the formation of the product. Only when adding a total of 1 molar equivalent of $\mathrm{CuSO}_{4} \cdot 5 \mathrm{H}_{2} \mathrm{O}$ and 0.5 molar equivalent of sodium ascorbate, the reaction proceeded and 179 was isolated in $67 \%$ yield after purification by chromatography. 


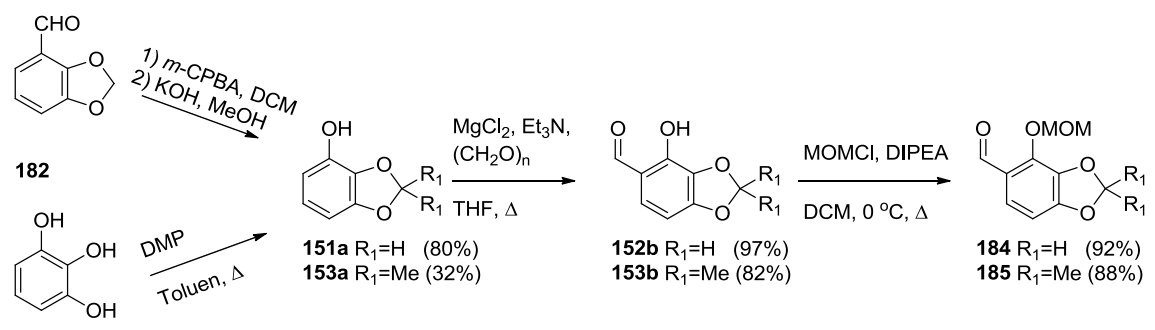

183

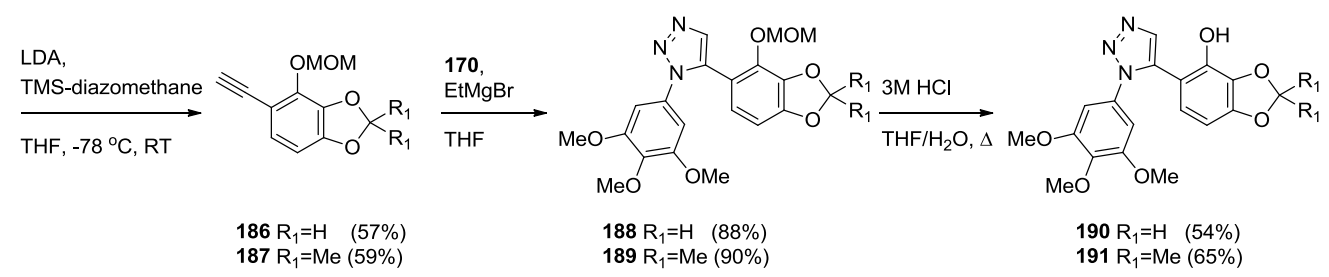

Scheme 16 Synthesis of CA-1 1,5-disubstituted-1,2,3triazole analogues.

The acetal 190 and acetonoide 191 were readily available in our laboratories using the selective ortho-formylation reaction of phenols as a key step in their preparation. Phenol 151a was acquired from the commercially available aldehyde 182 by a Baeyer-Villiger oxidation. ${ }^{256-258}$ Alternatively pyrogallol 183 was reacted with DMP to give phenol 153a. ${ }^{259}$ Both phenols were reacted with $\mathrm{Et}_{3} \mathrm{~N}$, $\mathrm{MgCl}_{2}$ and paraformaldehyde to provide the salicylaldehydes $151 \mathrm{~b}$ and 153b in excellent yields. The salicylaldehydes were protected with MOMCl using standard conditions. ${ }^{260,261}$ Alkynes $\mathbf{1 8 6}$ and 187 were obtained by the Colvin rearrangement from the protected aldehydes 184 and $\mathbf{1 8 5}$. To selectively synthesize the 1,5-disubstituted 1,2,3-triazoles the alkynes $\mathbf{1 8 6}$ and $\mathbf{1 8 7}$ were treated with ethylmagnesium bromide to produce the magnesium acetylides, which were reacted with the 3,4,5-trimethoxy azide 170. The MOM ethers were removed in refluxing $1: 1 \mathrm{THF} / 3 \mathrm{M} \mathrm{HCl}$ affording the 1,5-disubstituted 1,2,3-triazole CA-1 analogues 190 and $\mathbf{1 9 1}$ in 54\% and 65\% yield, respectively.

\subsubsection{Biological activities}

The CA-1 analogues in Figure 38 were evaluated for their cytotoxic activity in four cancer cell lines (MCF-7; breast cancer cell line, H460; lung cancer cell line, HT-29; colorectal cancer cell line and CEM; leukemia cell line), tubulin polymerization inhibition and anti-angiogenetic activity. The results are summarized in Table 8 . 
OMe

CA-1 (19)

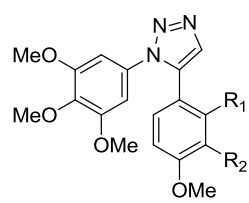

$178 \mathrm{R}_{1}=\mathrm{R}_{2}=\mathrm{NO}_{2}$

$180 \mathrm{R}_{1}=\mathrm{R}_{2}=\mathrm{NH}_{2}$

$192 \mathrm{R}_{1}=\mathrm{R}_{2}=\mathrm{H}$

$193 \mathrm{R}_{1}=\mathrm{H}, \mathrm{R}_{2}=\mathrm{NH}_{2}$

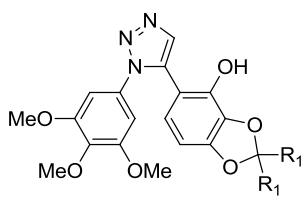

$190 \mathrm{R}_{1}=\mathrm{H}$

$191 \mathrm{R}_{1}=\mathrm{Me}$

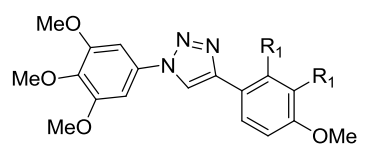

$179 \mathrm{R}_{1}=\mathrm{NO}_{2}$ $181 \mathrm{R}_{1}=\mathrm{NH}_{2}$

Figure 38 Combretastatin analogues evaluated in four cancer cell lines and their anti-angiogenetic and tubulin inhibitory activities.

Compound 192 had half the activity compared to CA-1 of tubulin polymerization inhibition. The diamino analogue $\mathbf{1 8 0}$ was less cytotoxic to the cancer cell lines tested, but exhibited improved antiangiogenetic activity compared to $\mathbf{1 9}$. It showed similar tubulin polymerization inhibition activity compared to CA-1 and CA-4 analogue 193. ${ }^{229}$ Compound 190 was cytotoxic to H460 and HT-29 cell lines and had similar anti-angiogenetic activity as CA-1 (19). From a practical point of view, compound 194 was considered inactive in the cell lines tested. The dinitro compound 178 was cytotoxic in all the cancer cell lines but also in the non-cancerous fibroblast cell line. Noteworthy, 178 was the only compound tested that was cytotoxic in the CEM cancer cell line. The 1,4disubstituted 1,2,3-triazole analogues $\mathbf{1 7 9}$ and $\mathbf{1 8 1}$ had some activity against the H460 cell line.

Table 8 Cytotoxicity, inhibition of angiogenesis and inhibition of tubulin of the 1,2,3-triazole CA-1 analogues.

\begin{tabular}{|c|c|c|c|c|c|c|c|}
\hline Compound & $\begin{array}{c}\mathrm{MCF}-7 \\
\text { cell assay } \\
\mathrm{IC}_{50}(\mu \mathrm{M})^{\mathrm{a}}\end{array}$ & $\begin{array}{c}\mathrm{H} 460 \\
\text { cell assay } \\
\mathrm{IC}_{50}(\mu \mathrm{M})^{\mathrm{a}}\end{array}$ & $\begin{array}{c}\text { HT-29 } \\
\text { cell assay } \\
\mathrm{IC}_{50}(\mu \mathrm{M})^{\mathrm{a}}\end{array}$ & $\begin{array}{l}\text { CEM cell } \\
\text { assay } \\
\mathrm{IC}_{50}(\mu \mathrm{M})^{\mathrm{a}}\end{array}$ & $\begin{array}{c}\text { Fibroblast } \\
\text { cell assay } \\
\mathrm{IC}_{50}(\mu \mathrm{M})^{\mathrm{a}}\end{array}$ & $\begin{array}{l}\text { Inhibition of } \\
\text { angiogenesis } \\
\quad(\mu \mathrm{M})^{\mathrm{a}}\end{array}$ & $\begin{array}{c}\text { Tubulin } \\
\text { inhibition } \\
(\mu \mathrm{M})^{\mathrm{b}}\end{array}$ \\
\hline 19 & 75.9 & 1.83 & 0.87 & $>100$ & $>100$ & 3.2 & $3.50^{\mathrm{c}}$ \\
\hline 178 & 6.14 & 0.73 & 12.0 & 26.0 & 31.5 & 4.39 & n.d. ${ }^{\mathrm{d}}$ \\
\hline 179 & $>100$ & 18.2 & $>100$ & $>100$ & $>100$ & $>10$ & n.d. ${ }^{\mathrm{d}}$ \\
\hline 180 & 38.8 & 17.3 & 17.3 & $>100$ & $>100$ & 0.25 & 5.20 \\
\hline 181 & $>100$ & 29.8 & $>100$ & $>100$ & $>100$ & $>10$ & n.d. ${ }^{\mathrm{d}}$ \\
\hline 190 & $>100$ & 7.44 & 8.80 & $>100$ & $>100$ & 3.44 & n.d. ${ }^{\mathrm{d}}$ \\
\hline 191 & 46.3 & 16.8 & $>100$ & $>100$ & $>100$ & $>10$ & n.d. ${ }^{\mathrm{d}}$ \\
\hline 192 & - & - & - & - & - & - & $7.00^{\mathrm{c}}$ \\
\hline 193 & - & - & - & - & - & - & $4.80^{\mathrm{c}}$ \\
\hline
\end{tabular}

${ }^{\mathrm{a}}$ Results of three experiments.

${ }^{\mathrm{b}}$ Results of two experiments.

${ }^{\mathrm{c}}$ Adapted from K. Odlos thesis or from Hansen and co-workers. ${ }^{113,229}$

${ }^{\text {n.d. }}=$ not determined 


\subsubsection{Conclusions}

In summary, six 1,2,3-triazole analogues of CA-1 were synthesized and evaluated for biological activities. The 1,5-disubstiuted 1,2,3-triazole analogue 180 of CA-1 exhibited cytotoxic effects against several cancer cell lines in the low micromolar range. In addition, it exhibited modest inhibition of tubulin assembly and effects with $\mathrm{IC}_{50}$-values in the comparable to $\mathrm{CA}-1$ and compound 193.

\subsection{Molecular modelling studies}

A set of 17 compounds, consisting of CA-1 (19), CA-4 (20), 1,4- and 1,5-disubstituted 1,2,3triazole CA-1 analogues (Figure 39), were docked into the colchicine binding site of tubulin. The molecules were synthesized in our labs except for compounds 194 and 195 which were virtual compounds. Post publication of the x-ray structure of the DAMA-colchicine-tubulin complex, there is a general consensus that TMP containing compounds must have the TMP superimposed with that of colchicine when docked into the tubulin structure. ${ }^{8}$

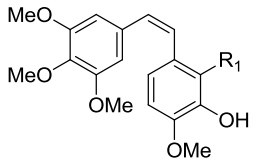

$19 \mathrm{R}_{1}=\mathrm{OH} \mathrm{CA}-1$

$20 \mathrm{R}_{1}=\mathrm{H} \mathrm{CA}-4$<smiles>[R]c1c(OC)ccc(-c2cnnn2-c2cc(OC)c(OC)c(OC)c2)c1[R]</smiles>

$178 \mathrm{R}_{1}=\mathrm{R}_{2}=\mathrm{NO}_{2}$ $180 \mathrm{R}_{1}=\mathrm{R}_{2}=\mathrm{NH}_{2}$

$192 \mathrm{R}_{1}=\mathrm{R}_{2}=\mathrm{H}$

$193 \mathrm{R}_{1}=\mathrm{H} \mathrm{R}_{2}=\mathrm{NH}_{2}$

$196 \mathrm{R}_{1}=\mathrm{R}_{2}=\mathrm{F}$

$197 \mathrm{R}_{1}=\mathrm{R}_{2}=\mathrm{OH}$

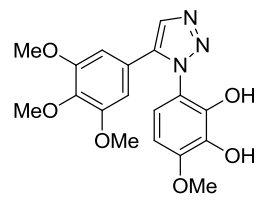

201

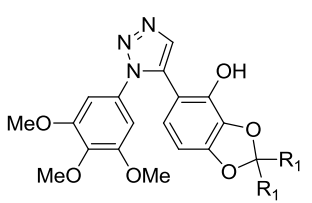

$190 \mathrm{R}_{1}=\mathrm{H}$

$191 \mathrm{R}_{1}=\mathrm{Me}$<smiles>[R7]c1ccc(-c2cnnn2-c2cc(OC)c(OC)c(OC)c2)c2cc[nH]c12</smiles>

$194 \mathrm{R}_{1}=\mathrm{H}$ $195 \mathrm{R}_{1}=\mathrm{OMe}$

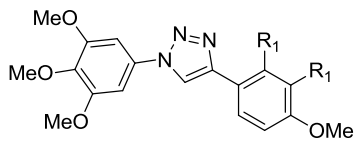

$179 \mathrm{R}_{1}=\mathrm{NO}_{2}$

$181 \mathrm{R}_{1}=\mathrm{NH}_{2}$

$198 \mathrm{R}_{1}=\mathrm{H}$

$199 \mathrm{R}_{1}=\mathrm{F}$

$200 \mathrm{R}_{1}=\mathrm{OH}$

Figure 39 Combretastatin analogues; virtual and synthesized for in silico docking.

\subsubsection{Coordinate scan}

By calculation (coordinate scan) the inversion barrier of the A- and B-ring of the 1,5-disubstituted 1,2,3-triazole analogues, 178, 180, 190-193, 196, 197, CA-1 and CA-4 were investigated and evaluated to determine if there was reason to suspect that the compounds are mixtures of enantiomers (Figure 40). Ahn and co-workers investigated the impact of different torsional angels 
to the biological activity of their analogues (57, 78 and 79, Section 1.4.4, Figure 13 and Figure 17). ${ }^{104}$ The authors observed that "an optical torsional angles" might be necessary for biological activity. The tubulin inhibition activity difference observed between enantiomers 56R and 56S (Section 1.4.4, Figure 13) indicate that the position of the A- and B-ring in the plane of the dioxolane ring affects activity.

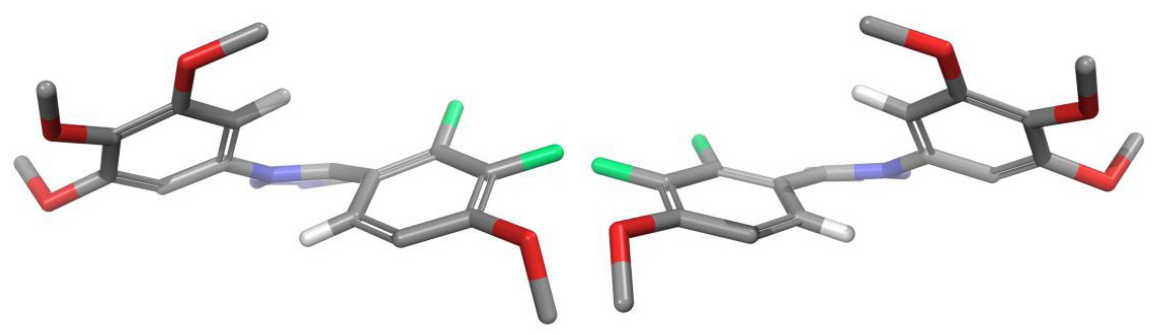

Figure 40 Chiral or mirror representation of difluoro analogue 196. The aromatic A- and B-rings are positioned over or under the plane of the triazole ring. Element colour; Carbon (grey), hydrogen (white), oxygen (red), nitrogen (blue) and fluoro (green).

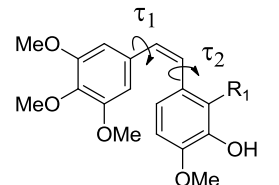

$19 \mathrm{R}_{1}=\mathrm{OH} \mathrm{CA}-1$ $20 \mathrm{R}_{1}=\mathrm{H}$ CA-4

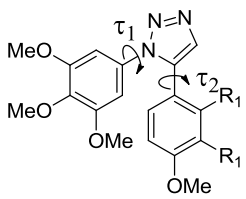

1,5-disubstituted-1,2,3-triazoles

Figure 41 The dihedral angles $\tau_{1}$ and $\tau_{2}$ were each changed with $5^{\circ}$ increments.

The two dihedral angles between the triazole and the A- $\left(\tau_{1}\right)$ and B-ring $\left(\tau_{2}\right)$ were systematically changed and the conformational energy calculated after energy minimization was performed (Figure 41). The energy plot for compound 178 is depicted in Figure 42, similar plots were obtained for the other compounds. The change in conformation occurs when the A-ring is 90 degrees on the triazole and $\tau_{2}$ changes from negative to positive when the C-2' and C-3' substituents are directed away from the TMP (Figure 43). 


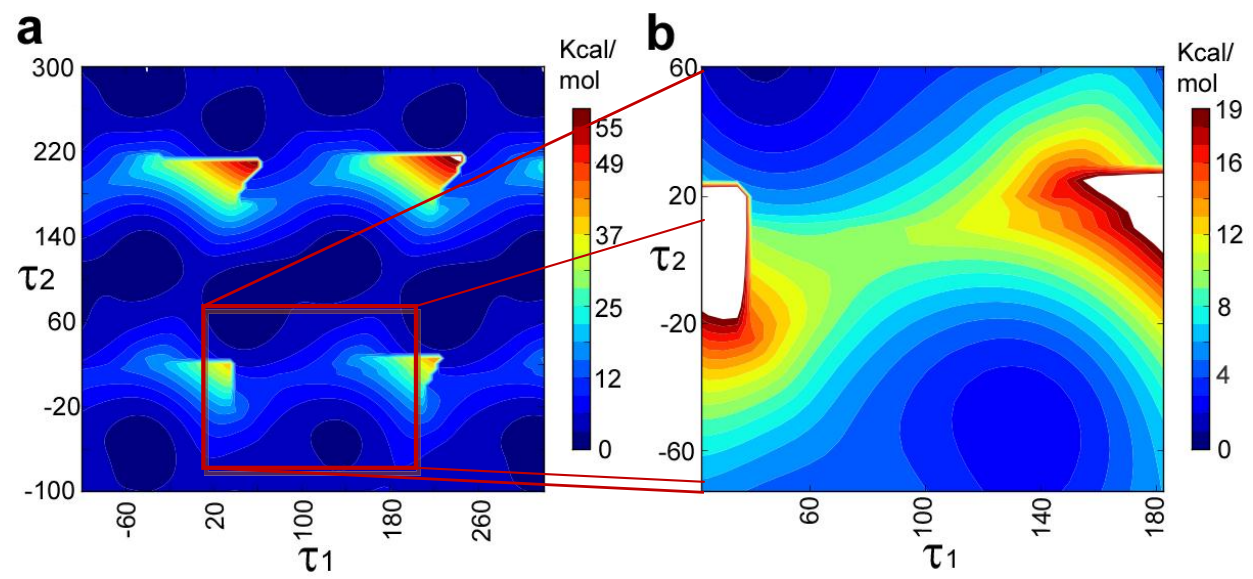

Figure 42 Energy (kcal/mol) plot of compound 178 when shifting the $\tau_{1}$ and $\tau_{2}$ angles. (a) The total relative energy surface. (b) Extraction of plot a. The inversion of conformation takes place between $\tau_{1}=90^{\circ}$ and $\tau_{2}=0^{\circ}$.

For CA-4 (20) and compounds 190-192, 196 and 197 the inversion barriers value were less than 5 $\mathrm{kcal} / \mathrm{mol}$ (appendix Table 9), which is a low energy barrier and indicates that the two enantiomers may interconvert and equilibrium between the two are established quickly at room temperature. In the case of CA-1 (19) and compounds 178, 180, 194 and 195 the energy barriers exceeded 5 $\mathrm{kcal} / \mathrm{mol}$ and were $6.4,9.2,9.7,8.5$ and $8.9 \mathrm{kcal} / \mathrm{mol}$, respectively. This indicates that 1,5disubstituted 1,2,3-triazoles synthesized with a large C-2' substitute are formed as enantiomeric mixtures.

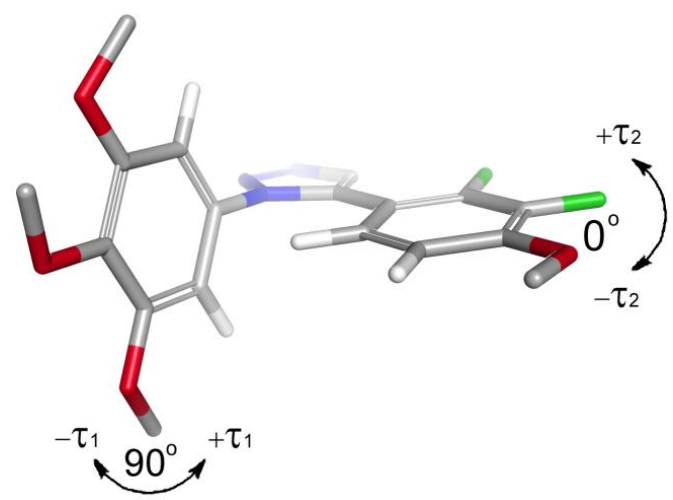

Figure 43 Angels of inversion of compound 196, $\tau_{1}=90^{\circ}$ and $\tau_{2}=0^{\circ}$.

The different enantiomers $\left(\tau_{1}\right.$ and $\tau_{2}$ or $-\tau_{1}$ and $\left.-\tau_{2}\right)$ were submitted for in silico docking into the tubulin structure. The results were comparable for the two enantiomers. However, the docking program stochastically selects conformations of the molecule, thus ignoring the conformation of the input structure. 


\subsubsection{Comparison of the 1SA0 and 1SA1 tubulin structure}

There are two tubulin-ligand complexes described in the literature, the ligands are DAMAcolchicine and podophyllotoxin, pdb entry code 1SA0 and 1SA1, respectively. Besides the different ligands, the two protein structures have been solved to different resolutions ( $3.58 \AA$ vs. $4.20 \AA$ ). A closer investigation of the binding pocket revealed that the backbones of the two proteins are aligned to within $5 \AA$ from the ligands except for residues Thr $\alpha 179$ and Ser $\alpha 178$, which are part of the T5 loop of $\alpha$-tubulin. For these two residues the back bone and side chains do not match, the side chains are pointing in opposite directions (Figure 44a). The side chain of residue Lys $\beta 254$ in the 1SA1 structure is not defined in the $\mathrm{x}$-ray crystal structure; the protein preparation wizard simulated a replacement equal to that of 1SA0. With the Sitemap function of the Schrödinger package the area around the ligand was investigated. The limits were defined as $3 \AA$ from the ligand and $1 \AA$ radius around the probes. Analysis of the receptor pocket illustrate that the $1 \mathrm{SA} 0$ pocket has a smaller hydrophobic area than the 1 SA1 pocket (332.1 $\AA^{2}$ vs. $\left.478.9 \AA^{2}\right)$, while the receptor sites total surface areas are virtually the same $\left(1567.3 \AA^{2}\right.$ (1SA0) vs. $1531.9 \AA^{2}$ (1SA1)). This indicates that 1SA1 more easily can accommodate ligands, as a major driving force for docking are hydrophobic interactions. Originating from the Thr $\alpha 179$ and Ser $\alpha 178$ side chains, a hydrophilic area in the 1SA0 structure was oriented towards the mercapto acetyl of DAMA-colchicine (Figure 44b). The corresponding polar surface in the 1SA1 structure is oriented differently, as expected looking at the amino acid residues.
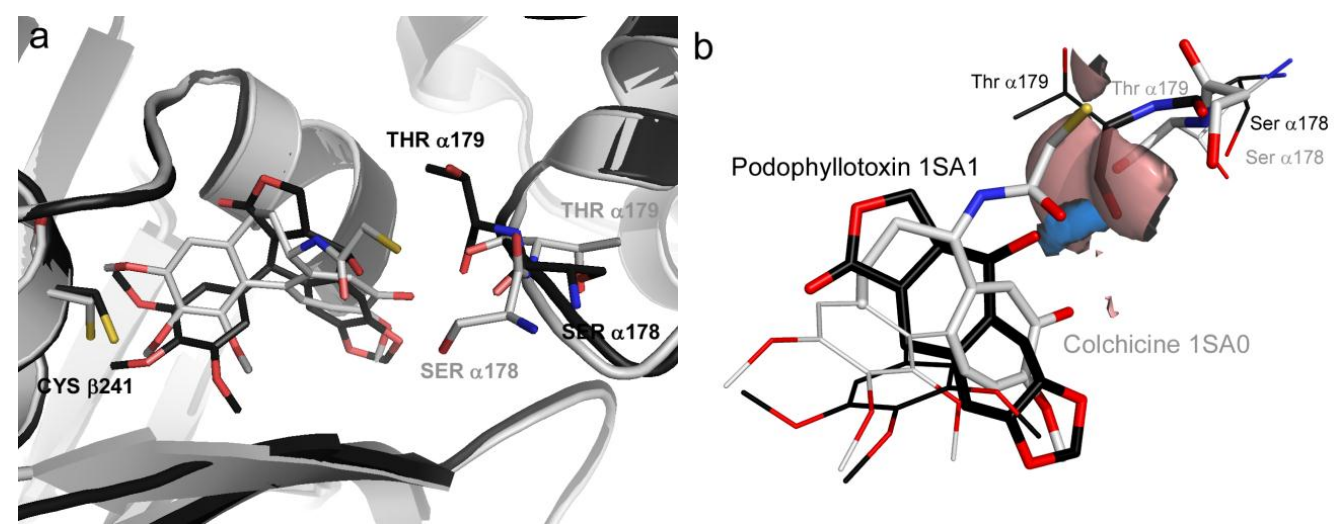

Figure 44 (a)1SA0 tubulin-DAMA-colchicine complex (gray) and the 1SA1 tubulin-podophyllotoxin complex (black). The side chains of the residues Thr $\alpha 179$ and Ser $\alpha 178$ are not superimposed in the two protein structures. (b) The polar surface of Thr $\alpha 179$ and Ser $\alpha 178$ side chains in the 1SA0 structure (red) is directed at the receptor pocket unlike the corresponding one in $1 \mathrm{SA} 1$ structure (blue). 


\subsubsection{Docking results}

As far as we have been able to establish, no docking studies of CA-1 analogues into the tubulin structure $1 \mathrm{SA} 0$ or $1 \mathrm{SA} 1$ have been reported in the literature. Therefore an investigation of what combination of program and protein which was best suited for this task was undertaken. The programs Autodock, Glide, Gold and FRED are amongst the most used programs for performing docking studies and were therefore chosen. ${ }^{138,262-266}$
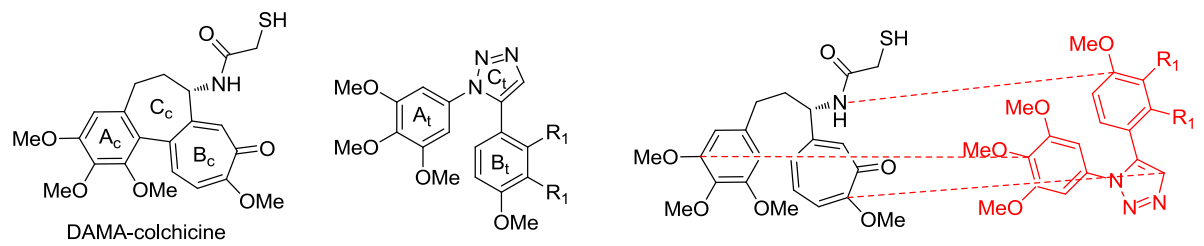

Figure 45 Illustration of the correct pose versus the flipped pose of CA-1 analogues.

The CA-1 analogues have a higher polarity compared to CA-4, since the B-ring have two polar substituents. The binding mode is considered correct when the rings of the triazole analogue are superimposed over the rings of colchicine, i.e. $A_{t}$ over $A_{c}$ and $B_{t}$ over $B_{c}$ and so on. A significant part of the dockings in the $1 \mathrm{SA} 0$ structure gave results where the triazole analogues were posed in a flipped mode. Ring A (TMP moiety) of the analogue was still superimposed over DAMAcolchicine, but the $B_{t}$ and $C_{t}$ have been vertically flipped (Figure 45). The prevalence of the flipped pose was reduced by changing to the protein complex 1SA1. Energetically or scoring wise, the flipped pose were not always significantly different from the correct pose (Appendix Table 10). The reason for the increased incidence of a flipped pose in the $1 \mathrm{SA} 0$ structure could be explained by the smaller pocket and the larger polar area oriented towards the receptor pocket originating from the residues Thr $\alpha 179$ and Ser $\alpha 178$.

For Autodock4 standard docking parameters yielded good results when docking the native ligand colchicine or podophyllotoxin. The parameters were optimized with the docking set (see Appendix). An advantageous function in Autodock4 is the cluster utility, which cluster together the various poses based on RMSD in a statistical diagram giving an estimation of the probability of existence. The $\mathrm{x}$ axis value describes the $\Delta \mathrm{G}$ score and the $\mathrm{y}$ axis value the population of the cluster. A good score has low $\mathrm{x}$-value and high $\mathrm{y}$-value with good energetic separation from other results. When docking the analogues in the 1SA0 structure, the cluster size and mean value between the correct pose and the flipped pose was for most of the compounds statistically different $(>0.5 \mathrm{kcal} / \mathrm{mol})$. The 
1,4-disubstituted 1,2,3-triazoles had scoring values (mean= -6.58 (1SA0) and -6.76 (1SA1) $\mathrm{kcal} / \mathrm{mol}$ ) comparable to the 1,5-disubstituted 1,2,3-triazoles (mean $=-7.29$ (1SA0) and -7.19 (1SA1) $\mathrm{kcal} / \mathrm{mol}$ ). Improvement of the docking poses was seen with the $1 \mathrm{SA} 1$ structure, there were no cluster with the flipped pose and the cluster with the correct docking was higher populated, but as with the 1SA0 structure the 1,4-triazoles gave unreasonably good scores. Generally, Autodock4 was quite slow, but has the advantage of offering a statistical tool for analysis of the results.

The FRED program and the 1SA0 structure gave poor results and the flipped pose was favoured, having better scores, over dockings which were more or less superimposed over colchicine. The results were significantly improved with the use of the 1SA1 structure. The 1,5-disubstituted-1,2,3triazole analogues of CA-1 gave good scores (mean = -83.0) while the 1,4-disubstituted 1,2,3triazole analogues gave low scores (mean $=-53.6)$.

The Schrödinger packaged Glide program faced equal problem as Autodock4 in docking into 1SA0, the flipped pose was present and with quite similar docking score to the correct pose (mean= -7.30 (flipped) vs. -8.14 (correct) kcal/mol). An improvement of using Glide over Autodock4 was the docking of the 1,4-disubstituted 1,2,3-triazoles. They received low scores with Glide (mean= -5.93 $\mathrm{kcal} / \mathrm{mol}$ ) in the $1 \mathrm{SA} 0$ structure and were not amendable in the $1 \mathrm{SA} 1$ structure. Using the 1SA1 structure in Glide improved the docking compared to the 1SA0 structure. There were still presences of the flipped pose (compound 180, 190, and 193). An unexpectedly high score was seen with compounds $197(-9.47 \mathrm{kcal} / \mathrm{mol})$ and $180(-9.60 \mathrm{kcal} / \mathrm{mol})$. When superimposing these two compounds over those with correct pose but, significantly lower score, did not reveal any great difference in positioning (data not shown).

Gold gave acceptable docking results with Goldscore in the 1SA0 structure. Of the 1,5-disubstituted 1,2,3-triazoles about half of the molecules were docked in the flipped pose and their score was significantly different from the correct pose (mean $=61.7$ (correct) vs. 52.9 (flipped)). Two of the 1,4-disubstituted 1,2,3-triazoles (179 and 198) were found in the binding pocket of 1SA0 with their TMP in superimposed over that of colchicine. The program was not able to dock into the receptor pocket when using the Chemscore function.

Gold and Goldscore function was also satisfactory with 1SA1, only one entry was found in the flipped pose 194 and the 1,4-disubstituted 1,2,3-triazole 198 was found in the receptor pocket. The score of the correct pose in the 1SA1 structure was comparable to $1 \mathrm{SA} 0$ (mean $=61.7$ (1SA0) vs. 65.5 (1SA1)). The Gold program was very slow, calculation time for one molecule ranges from 0.5 - 
$1.5 \mathrm{~h}$, whereas FRED completed the docking of all the analogues within $5 \mathrm{~min}$. The CPU time/cost with Gold is significantly higher than for FRED and Glide but comparable with Autodock4. The best results was obtained with FRED and the 1SA1 structure complex as it was fast and 1,5disubstituted 1,2,3-triazoles and 1,4-disubstituted 1,2,3-triazoles have significantly different scoring values.

The CA-1 analogues have a higher polarity compared to CA-4, since the B-ring have two polar substitutions. The docking program frequently positioned these substituents towards the polar surface created by the residues Thr $\alpha 179$ and Ser $\alpha 178$. This leads to the ligands posing in a flipped mode. As seen in all the flipped docking results they all have the possibility for a hydrogen bond to Ser $\alpha 178$, a bond not seen with the analogues docked in the 1SA1 structure.

All docking programs were able to find a conformation of the docked analogue corresponding to that of colchicine or podophyllotoxin where the TMP was in the same Cartesian space as that of the native ligand in the parent ligand-protein complex (Figure 46). In most cases this was the docking with the best score. Similar combretastatin triazole analogues have been docked by others who also managed to match the TMP moiety with colchicine. ${ }^{29,244-246}$ Unfortunately none of the programs were able to rank, with their scoring function, the ligands according to their in vitro tubulin polymerization $\mathrm{IC}_{50}$ values. The lack of correlation of in vitro tubulin inhibition and in silico results is most likely due to few ligands with little diversity of structure and potency making it hard for the scoring function to accurately discriminate between them. Molecular docking is a great tool for hit identification but scoring the poses remains a problem. ${ }^{140,267}$ 


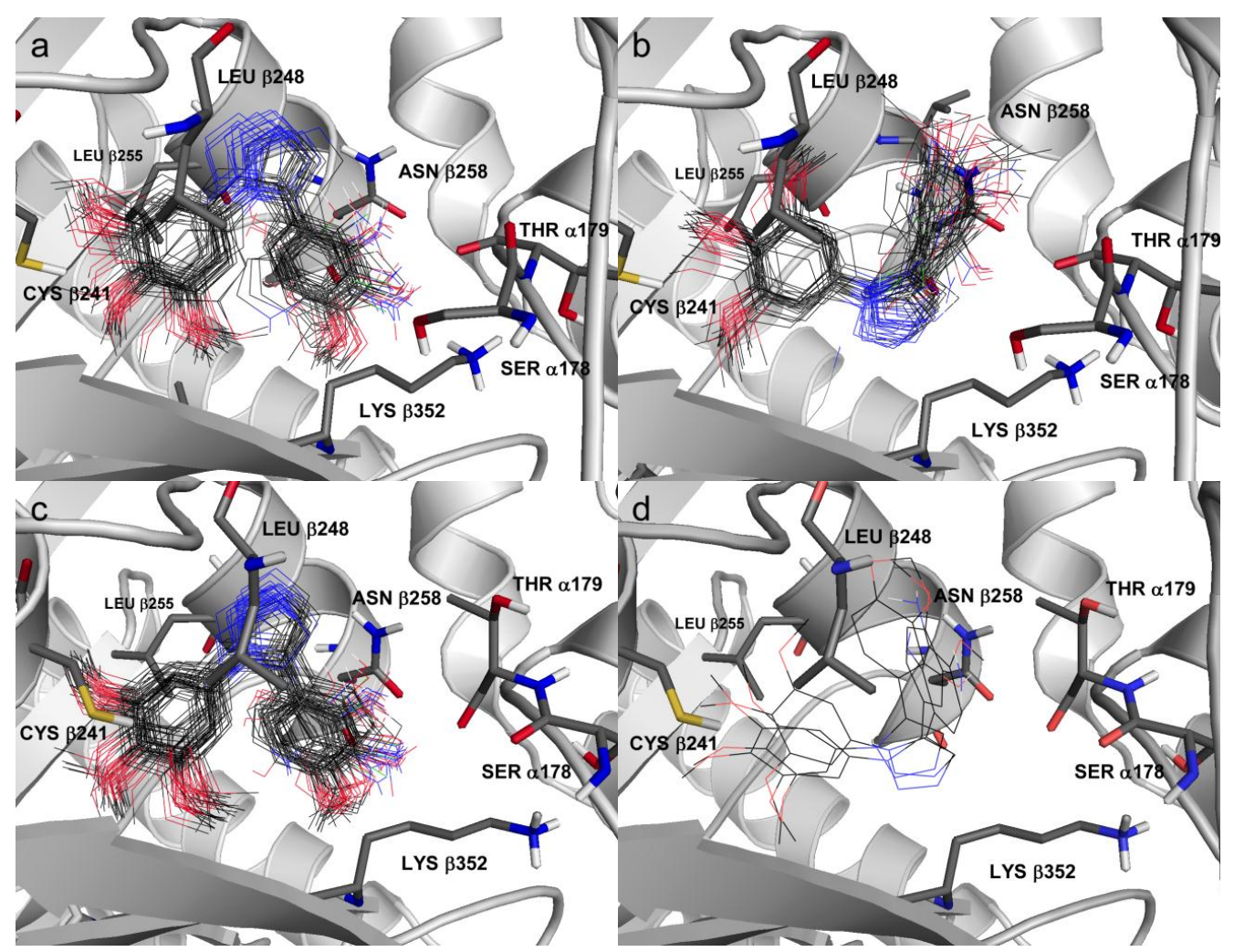

Figure 46 (a) All the analogues docked in the correct pose in the 1SA0 structure (b) All the analogues docked in the flipped pose in the 1SA0 structure (c) All the analogues docked in the correct pose in the 1SA1 structure (d) All the analogues docked in the flipped pose in the 1SA1 structure.

\subsubsection{Minimization}

The result complexes from the Glide docking were energy minimized with Macromodel after the reinsertion of GDP and GTP that were removed with the protein preparation wizard. The proteinligand interaction was analysed with the aid of the Sitemap function in the Schrödinger package. The hydrophobic, hydrogen-donor and -acceptor maps were generated of the energy minimized protein-ligand complex (Figure 47). 


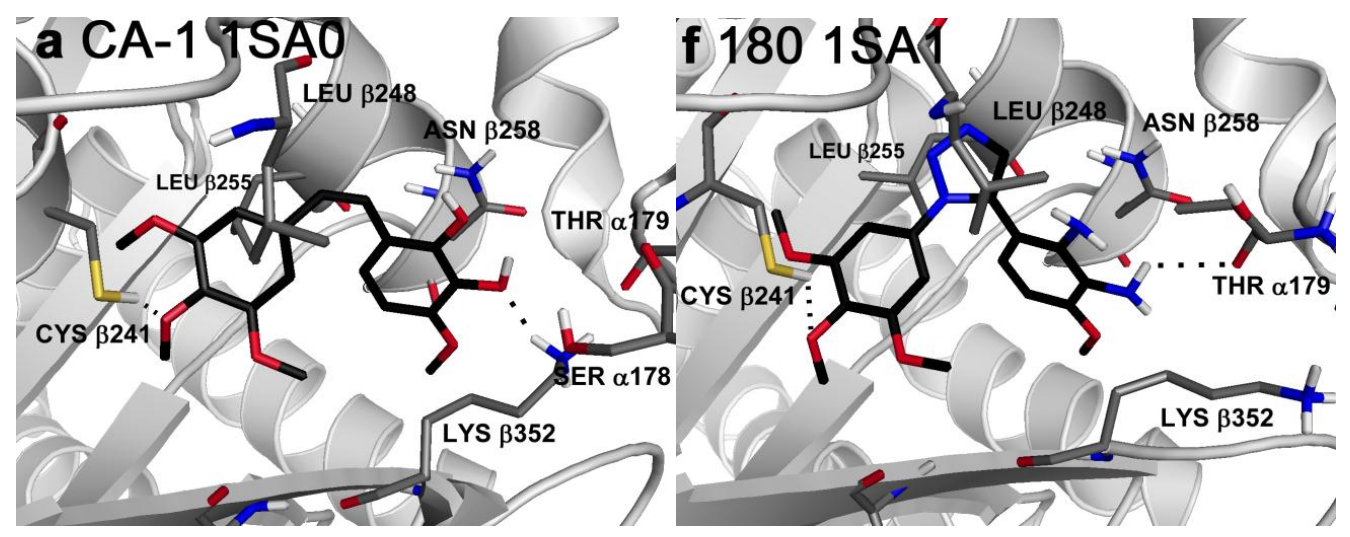

\section{c CA-1 flipped 1SAO}
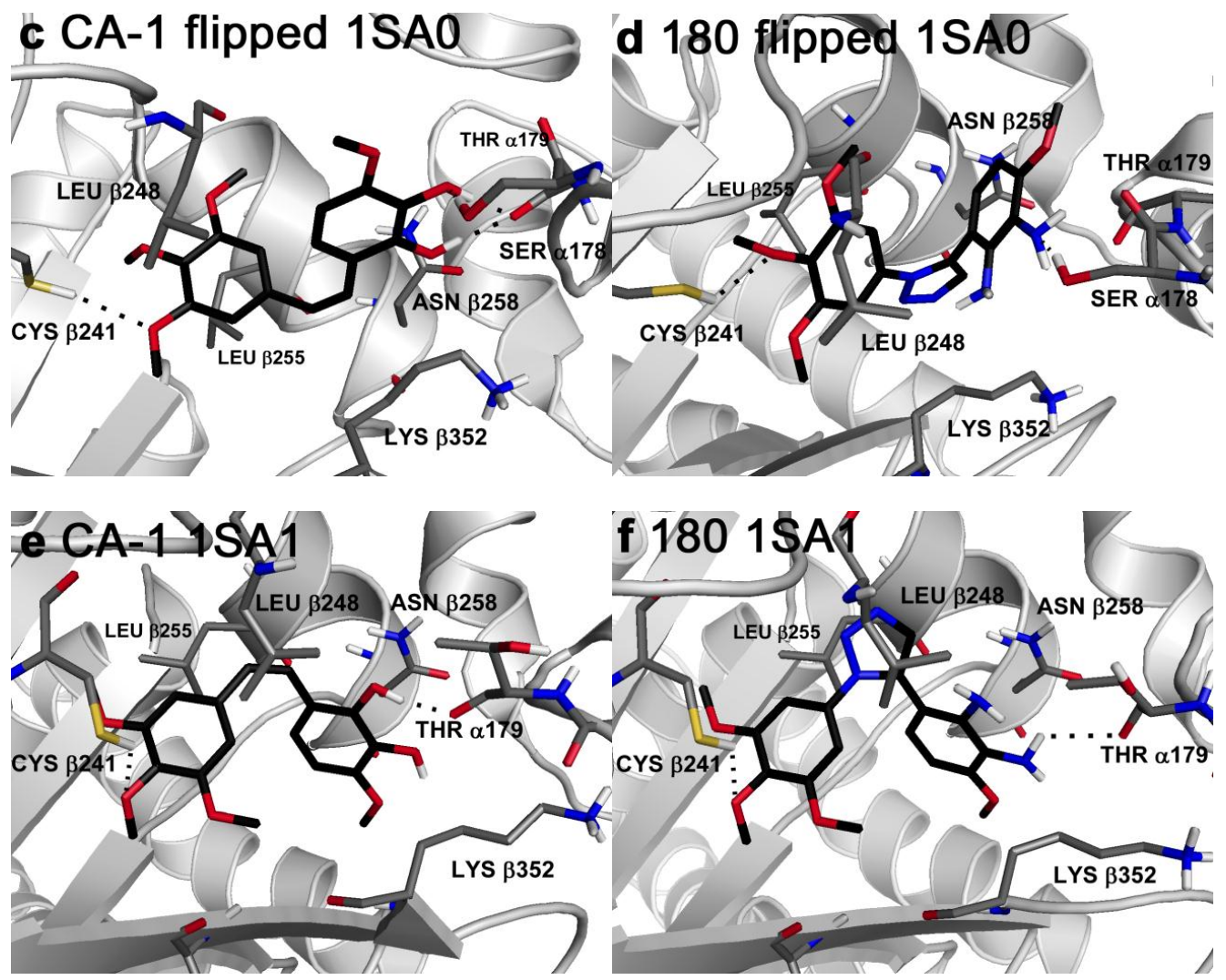

Figure 47 Docking poses after energy minimization. Hydrogen bonds are represented by black dotted lines.

\subsubsection{Possible hydrogen bonds}

Glide was not able to rank the ligands according to their in vivo activity. Hence, a thorough evaluation and comparison of the bond strengths is superfluous. A brief evaluation of the possible hydrogen bonds in the protein-ligand complexes of CA-1 (19) and analogue 180 with $1 \mathrm{SA} 0$ or 
1SA1 as well as their flipped pose will follow.

In $1 \mathrm{SA} 0$ the 4-OMe group is a possible hydrogen bond acceptor of the thiol proton of Cys $\beta 241$, when CA-1 (Figure $47 \mathrm{a}, \mathrm{c}$ and e) was docked in the correct binding mode. Lysine residues are normally protonated at physiological $\mathrm{pH}$, and an ion-dipole interaction between Lys $\beta 352$ ammonium ion and 3'-OH is possible. The flipped pose can acts as a hydrogen bond donor from 2'$\mathrm{OH}$ to the carbonyl of Thr $\alpha 179$ and between 3'-OH and Ser $\alpha 178$. The 3'-OH and 3-OMe are close enough for $\mathrm{H}$-acceptor interactions to the side chain hydroxyl group of Ser $\alpha 178$ and thiol proton of Cys $\beta 241$ respectively. The only possible hydrogen bonds between CA-1 and 1SA1 structure were Thr $\alpha 179$, and the thiol proton of Cys $\beta 241$ which are within distance $2^{\prime}-\mathrm{OH}$ and 4-OMe, respectively.

For the most biologically potent 1,2,3-triazole analogue investigated, $\mathbf{1 8 0}$ (Figure $47 \mathrm{~b}, \mathrm{~d}$ and f), the 4-OMe was within distance of the thiol proton of Cys $\beta 241$ to act as a hydrogen bond acceptor. A possible ion-dipole interaction between the ammonium ion of the Lys $\beta 352$ side chain and the 3'$\mathrm{NH}_{2}$ group was recognized. In the flipped pose the $3^{\prime}-\mathrm{NH}_{2}$ group could be a hydrogen bond donor to the carbonyl of Ser $\alpha 178$ and the 3-OMe group was within distance of the thiol proton of Cys $\beta 241$ to act as hydrogen bond acceptor. In $1 \mathrm{SA} 1$ structure the $3^{\prime}-\mathrm{NH}_{2}$ group was close enough to Thr $\alpha 179$ to act as a hydrogen bond donor. The 3-OMe group was within distance of the thiol proton of Cys $\beta 241$ to act as hydrogen bond acceptor.

CA-1 (19) and 180 display similar interactions with the surrounding tubulin residues, this could rationalize their observed tubulin inhibition activity $\left(\mathrm{IC}_{50}=3.5\right.$ and $\left.5.2 \mu \mathrm{M}\right)$.

\subsubsection{Hydrophobic interactions}

\section{Possible hydrophobic interactions of the A-ring}

The colchicine binding site of tubulin consists of residues creating a hydrophobic pocket that accommodate the ligand. The residues that make up the hydrophobic space for the TMP are conserved for the 1SA0 correct and flipped pose, and the 1SA1 correct conformation as the TMP is occupying the same Cartesian space in all three modes. The residues Leu $\beta 248$ and Leu $\beta 255$ create a box for the TMP moiety together with Ala $\beta 316$, Ala $\beta 317$, Lys $\beta 352$, and Ile $\beta 378$ in all three dockings. Furthermore, the analogues in the correct pose in the two structures 1SA0 and 1SA1 share hydrophobic contribution from residues Val $\beta 238$, Val $\beta 351$ and Ala $\beta 354$. Leu $\beta 242$ only interacts with the analogues in the correct conformation in 1SA0 structure. The TMP of the 
analogues in the 1SA1structure interacts with Ala $\beta 250$ which was also shared with the flipped pose in the 1SA0 structure. The TMP moiety of the flipped poses enjoys hydrophobic interactions with the three residues Lys $\beta 254$ and Val $\beta 318$ which the correct conformations do not.

\section{Possible hydrophobic interactions of the B-ring}

The hydrophobic B-ring pocket consists of the same residues in both structures for the correct poses. The aliphatic contributions to the B-ring in both the 1SA0 and 1SA1 come from Ala $\alpha 180$, Val $\alpha 181$ and the $\beta$ and $\gamma$ carbons of Lys $\beta 352$ side chain. Furthermore, residues Leu $\beta 255$, Asn $\beta 258$, Met $\beta 259$, Val $\beta 315$ and Ala $\beta 316$ also contribute. Generally the amide side chain of Asn $\beta 258$ can be seen as coplanar to the aromatic B-ring, which could indicate aliphatic interaction between the two, this co-planarity was not seen for the flipped pose. The only different hydrophobic contributing residues are Asn $\beta 350$ for the 1 SA 0 and Leu $\beta 248$ for 1 SA1.

The B-ring of the flipped poses is placed in a hydrophobic area spanned out by Ala $\alpha 180$, Leu $\beta 248$, Asn $\beta 258$, Lys $\beta 352$ and Ala $\beta 354$.

\section{Possible hydrophobic interactions of the 1,2,3-triazole}

The correct pose triazole in the 1SA0 and 1SA1 structures occupies a hydrophobic pocket consisting of the same residues in the two structures; Leu $\beta 248$, Ala $\beta 250$, Lys $\beta 254$, Leu $\beta 55$ and Asn $\beta 258$. Around the triazole in the flipped dockings we find aliphatic contributions from Val $\alpha 181$, Leu $\beta 255$, Ala $\beta 316$, Met $\beta 259$ and the $\gamma$ carbons of Lys $\beta 254$ side chain.

\subsubsection{Conclusions}

The 1,5-disubstituted 1,2,3-triazole analogues of CA-1 were able to occupy the same Cartesian space as the native ligands of the tubulin complexes $1 \mathrm{SA} 0$ and $1 \mathrm{SA} 1$. This indicates that there is reason to expect biological activity of the docked compounds which have not yet been synthesized or biologically tested (compounds 194 and 195). A flipped pose was identified for the 1,5disubstituted 1,2,3-triazole analogues of CA-1 in the 1SA0 structure with similar docking score as the correct conformation. The Thr $\alpha 179$ and Ser $\alpha 178$ combined created a significantly larger polar surface oriented towards the binding site in the $1 \mathrm{SA} 0$ structure than in the $1 \mathrm{SA} 1$ structure. This was believed to contribute to the flipped pose docking results. 


\section{Conclusions}

The need for new anti-cancer drugs is apparent. Classical medicinal chemistry has for decades provided new chemical entities and will most likely do so in the proximal future. Nature continues to be a primary source for new chemical leads and inspiration towards anti-cancer agents.

Targeting $p$ Casp3/caspase-3 in cells with dysfunctional apoptotic pathway is a logical sound strategy both in hyper- and hypoactive disorders. Indirect activation was effectuated by PAC-1 through relief of zinc inhibition of $p$ Casp-3/caspase-3, though neurotoxicity emerged in the in vivo trials. Neuron cells isolated from chicken were found as a suitable model to study mechanisms of interference with apoptosis of PAC-1 and similar compounds. The two PAC-1 derivatives that were synthesized, 128 and 130, were more active than PAC-1 in seven cancer cell lines and was cytotoxic to PC12 cells in comparable concentration to PAC-1 (12).

The ortho-formylation reaction using the $\mathrm{MgCl}_{2} / \mathrm{Et}_{3} \mathrm{~N}$ base system has proven to be a practical and environmentally benign method as evident from its many applications. It has now been extended to involve also mono-protected resorcinols and estrogens, exerting good to excellent regioselectivity and yields in most cases. Furthermore, this reaction was a key step for the preparation of analogues of combretastatin A-1 and PAC-1, as well as in the total synthesis of 2ME2.

The natural compound combretastatin A-1 has recently received increased attention. Replacing the olefinic bridge with the 1,2,3-triazole moiety yielded configurationally restricted analogues of CA-1 (19). The 1,5-disubstiuted 1,2,3-triazole analogue $\mathbf{1 8 0}$ of combretastatin A-1 exhibited cytotoxic effects against several cancer cell lines in the low micromolar range. In addition, $\mathbf{1 8 0}$ exhibited modest inhibition of tubulin assembly with $\mathrm{IC}_{50}$-values in the low micromolar range. Molecular modelling studies indicated that the 1,5-disubstituted 1,2,3-triazole CA-1 analogues were challenging to dock into the 1SA0 structure of tubulin, and that the tubulin-podophyllotoxin complex (1SA1) is a better suited structure for docking of 1,5-disubstiuted 1,2,3-triazole CA-1 analogues. These docking studies may form the basis for new analogues of CA-1. 


\section{Future perspectives}

Professor E.J. Corey's group has synthesized potent anti-angiogenetic agents. Design of these compounds was inspired by cortistatin A, a natural anti-angiogenetic compound isolated from the marine sponge Corticulum simplex. These analogues are structurally less complex and easier to synthesize than the natural product. Functional studies have shown they inhibit capillary cell growth, migration, in vitro tube formation, and in vivo angiogenesis in the living retina of neonatal mice. $^{268}$
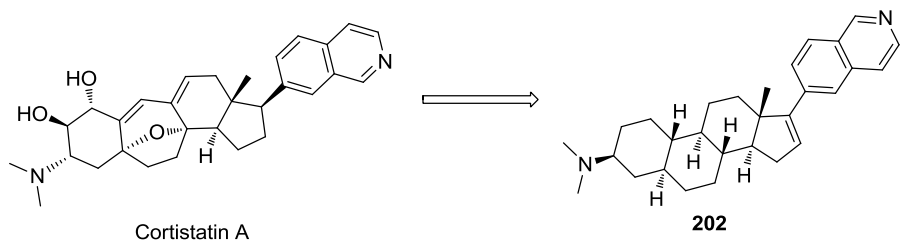

Figure 48 Cortistatin A and a potent derivative.

This prompted us to investigate if $2 \mathrm{ME} 2$ could adopt the substitution pattern of 202. Employing the same procedure as to $\mathbf{2 0 2}$ to oxidized and protected 2ME2 could yield interesting compounds, such as 205 .

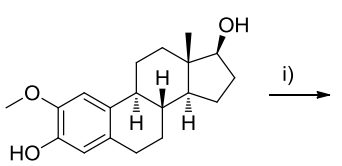

2ME2 (85)

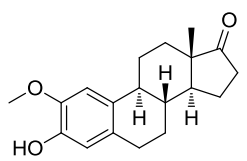

$203(75 \%)$

i) Cyclohexanone, $\mathrm{Al}(\mathrm{O}-\mathrm{i}-\mathrm{Pr})_{3}$, Toluene, $\Delta$

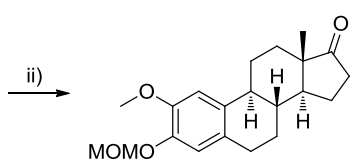

$204(76 \%)$

DIPEA, MOMCI, THF, $\Delta$

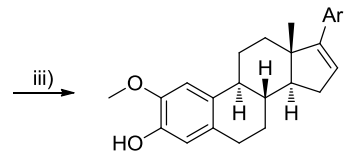

205

$\mathrm{Ar}=6$-tributylstannyl-isoquinoline iii) 1) KHMDS, $\mathrm{PhN}\left(\mathrm{SO}_{2} \mathrm{CF}_{3}\right)_{2}$ 2) $\mathrm{LiCl}$, Stille, Ar-stannane 3) $\mathrm{HCl}, \mathrm{THF} / \mathrm{H}_{2} \mathrm{O}$

Scheme 17 Synthetic scheme for analogues of 2ME2.

Available from the ortho-formylation reaction compound $\mathbf{1 0 0}$ can serve as a starting material. It can be transformed into a $2 \mathrm{ME} 2$ analogue by known synthetic methods and thereafter cycloaddition reactions can be performed with the $17 \alpha$-etynyl resulting in heterocyclic derivatives, such as $\mathbf{2 0 7}$.

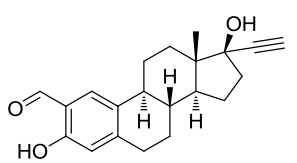

100

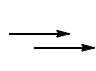<smiles>C#C[C@]1(O)CC[C@H]2[C@H]3CCc4cc(O)c(OC)cc4[C@H]3CC[C@]21C</smiles>

206

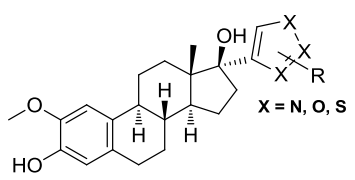

207

Figure 49 2ME2 analogues from compound $\mathbf{1 0 0}$.

Further studies in our group are on-going based on the chemistry presented in this thesis and outlined in Scheme 17 and Figure 49. 


\section{Appendix}

\subsection{General}

Unless noted otherwise, all reagents and solvents were used as purchased without further purification. Melting points are uncorrected. Analytical TLC was performed using silica gel $60 \mathrm{~F}_{254}$ plates (Merck) or RP-18 $\mathrm{F}_{254 \mathrm{~s}}$ plates (Merck). Flash column chromatography was performed on silica gel $60\left(40-63 \mu \mathrm{m}\right.$, Fluka). NMR $\left({ }^{1} \mathrm{H},{ }^{13} \mathrm{C}\right)$ spectra were recorded on a Bruker DPX-300 MHz or DPX-200 MHz spectrometer. Coupling constants $(J)$ are reported in hertz, and chemical shifts are reported in parts per million $(\delta)$ relative to $\mathrm{CDCl}_{3}\left(7.26 \mathrm{ppm}\right.$ for ${ }^{1} \mathrm{H}$ and $77.00 \mathrm{ppm}$ for $\left.{ }^{13} \mathrm{C}\right)$, DMSO- $d_{6}\left(2.50 \mathrm{ppm}\right.$ for ${ }^{1} \mathrm{H}$ and $39.43 \mathrm{ppm}$ for $\left.{ }^{13} \mathrm{C}\right)$, acetonitrile- $d_{3}\left(1.94 \mathrm{ppm}\right.$ for ${ }^{1} \mathrm{H}$ and $1.32 \mathrm{ppm}$ for ${ }^{13} \mathrm{C}$ ), $\mathrm{CD}_{3} \mathrm{OD}\left(4.87 \mathrm{ppm}\right.$ for ${ }^{1} \mathrm{H}$ and 49.15 for ${ }^{13} \mathrm{C}$ ) or $\mathrm{D}_{2} \mathrm{O}$ (4.79 ppm for ${ }^{1} \mathrm{H}$ ). Compounds $\mathbf{1 3 7},{ }^{269} \mathbf{1 5 4},{ }^{269}$ and $\mathbf{1 5 5}^{270}$ are known. The western blot (Figure 32) was performed by Mona Gaarder with the same method as described in paper II.

\subsubsection{MTT assay}

PC12 cells were grown in DMEM supplemented with 10\% foetal calf serum, 5\% horse serum, sodium pyruvate, and penicillin/streptomycin in a 96 well plate. After $24 \mathrm{~h}$ the cells were treated with sample compound at different concentrations, dissolved in DMSO $(0.1 \%$ final concentration) for 48 hours. MTT solution was made by dissolving 3-(4,5-dimethylthiazol-2-yl)-2,5-diphenyl tetrazolium in PBS and then filtered to a final concentration of $5 \mathrm{mg} / \mathrm{mL}$. $50 \mu \mathrm{L}$ of MTT solution is added to each well and the cells were allowed to incubate for $1 \mathrm{~h}$ at $37^{\circ} \mathrm{C}$. After removing of medium, the cells and dye crystals were solubilized by adding $100 \mu \mathrm{l}$ of DMSO, and the absorption was measured at $570 \mathrm{~nm}$ by an ELISA reader.

\subsubsection{Synthesis of starting materials}

3-Bromo-2,6-dihydroxybenzaldehyde (158). To a stirring solution of 3-bromo-6-((tertbutyldimethylsilyl)oxy)-2-hydroxybenzaldehyde (149c, $144 \mathrm{mg}, 0.43 \mathrm{mmol})$ in $\mathrm{THF}(2 \mathrm{~mL})$ at $0{ }^{\circ} \mathrm{C}$ TBAF $(0.52 \mathrm{~mL}, 1 \mathrm{M})$ was added. The solution was stirred for $10 \mathrm{~min}$ before $\mathrm{Et}_{2} \mathrm{O}(10 \mathrm{~mL})$ and $\mathrm{HCl}$ $(10 \mathrm{~mL}, 1 \mathrm{M})$ were added. The reaction mixture was transferred to a separatory funnel and the aq. phase was back extracted with $\mathrm{Et}_{2} \mathrm{O}(3 \mathrm{x} 5 \mathrm{~mL})$. The combined organic phases was dried over anhydrous magnesium sulphate and concentrated in vacou. The yellow crude product was purified by chromatography to yield 158 (70\%); mp $161-162{ }^{\circ} \mathrm{C}$ (heptane); $\mathrm{R}_{\mathrm{f}}=0.32(6: 4$, heptane:EtOAc); ${ }^{1} \mathrm{H}$ NMR $(300 \mathrm{MHz}, \mathrm{MeOH}) \delta 10.25(\mathrm{~s}, 1 \mathrm{H}), 7.49(\mathrm{~d}, J=8.8 \mathrm{~Hz}, 1 \mathrm{H}), 6.31(\mathrm{~d}, J=8.8 \mathrm{~Hz}, 1 \mathrm{H}) ;{ }^{13} \mathrm{C}$ 
NMR (75 MHz, MeOH) $\delta=195.44,162.87,159.91,142.06,112.14,108.86,99.60$.

3-((2,3-Dimethylbutan-2-yl)dimethylsilyloxy)phenol (139). To a solution of resorcinol (220 mg, 2 mmol) in DMF (3 mL), DBU (334 mg, $2.2 \mathrm{mmol})$ and chloro(2,3-dimethylbutan-2yl)dimethylsilane (392 mg, $2.2 \mathrm{mmol}$ ) were added and stirred over night. The crude reaction mixture was transferred directly to silica for column chromatography (9:1, hexane:EtOAc). Colourless oil (20\%); $\mathrm{R}_{\mathrm{f}}=0.48$ (8:2, hexane:EtOAc); ${ }^{1} \mathrm{H}$ NMR $\left(300 \mathrm{MHz}, \mathrm{CDCl}_{3}\right) \delta=7.05(\mathrm{t}, J=$ $8.1,1 \mathrm{H}), 6.41$ (ddd, $J=1.3,2.2,8.0,2 \mathrm{H}), 6.33(\mathrm{t}, J=2.3,1 \mathrm{H}), 4.92(\mathrm{~s}, 1 \mathrm{H}), 1.71(\mathrm{~m}, 1 \mathrm{H}), 0.93(\mathrm{t}, J$ $=3.4,12 \mathrm{H}), 0.21(\mathrm{~s}, 6 \mathrm{H}) .{ }^{13} \mathrm{C}$ NMR $\left(75 \mathrm{MHz}, \mathrm{CDCl}_{3}\right) \delta=156.80,156.49,129.89,112.76,108.33$, $107.60,34.11,25.02,20.11,18.54,-2.46$.

\section{$(8 R, 9 S, 13 S, 14 S)-3-H y d r o x y-2-m e t h o x y-13-m e t h y l-7,8,9,11,12,13,15,16-0 c t a h y d r o-6 H-$} cyclopenta[a]phenanthren-17(14H)-one (203). 2-Methoxyestradiol (3.0 g, $10 \mathrm{mmol})$ was placed in a $250 \mathrm{~mL}$ round-bottomed flask that was equipped with reflux condenser. Toluene $(150 \mathrm{~mL})$, aluminium isopropoxide $(10 \mathrm{~g}, 50 \mathrm{mmol})$ and cyclohexanone $(30 \mathrm{~mL}, \mathrm{mmol})$ were added to the suspension. The entire reaction mixture was heated at reflux $\left(120^{\circ} \mathrm{C}\right)$ for $20 \mathrm{~h}$. The reaction mixture was allowed to cool to room temperature and the suspension was treated with $3 \mathrm{~N} \mathrm{HCl}$ until the gelemulsion dissolved and the phases separated. The aqueous layer was extracted with $\mathrm{Et}_{2} \mathrm{O}(3 \mathrm{x} 50$ $\mathrm{mL})$ and EtOAc (3x $50 \mathrm{~mL})$. The combined organic extracts were dried over anhydrous magnesium sulfate, concentrated in vacuo, and distilled $\left(120-140^{\circ} \mathrm{C}\right)$ under reduced pressure. The resulting yellow crude was triturated with boiling hexane and left in freezer over night. The organic phase was decantated of and the colourless powder was washed with additional cold hexane before drying on high vacuum pump affording 2-methoxyestrone. Colourless solid (75\%); mp 184-185 ${ }^{\circ} \mathrm{C}$

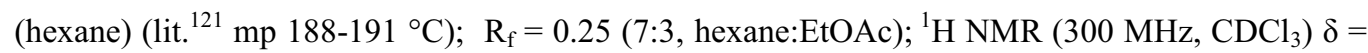
$6.79(\mathrm{~s}, 1 \mathrm{H}), 6.66(\mathrm{~s}, 1 \mathrm{H}), 3.86(\mathrm{~s}, 3 \mathrm{H}), 2.91-2.73(\mathrm{~m}, 2 \mathrm{H}), 2.51(\mathrm{dd}, J=18.4,8.4 \mathrm{~Hz}, 1 \mathrm{H}), 2.43-$ $2.32(\mathrm{~m}, 1 \mathrm{H}), 2.32-1.90(\mathrm{~m}, 5 \mathrm{H}), 1.75-1.22(\mathrm{~m}, 6 \mathrm{H}), 0.92(\mathrm{~s}, 3 \mathrm{H}) ;{ }^{13} \mathrm{C} \mathrm{NMR}\left(75 \mathrm{MHz}, \mathrm{CDCl}_{3}\right) \delta$ $=144.65,143.59,131.05,129.22,114.61,108.00,55.99,50.34,47.95,44.21,38.29,35.83,31.56$, $28.80,26.55,26.17,21.51,13.82$.

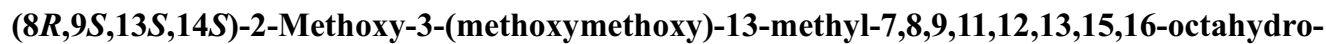
6H-cyclopenta[a]phenanthren-17(14H)-one (204). Compound 203 (800 mg, $2.6 \mathrm{mmol}$ ) was dissolved in THF under argon. Diisopropylethylamine $(1.33 \mathrm{~mL}, 7.8 \mathrm{mmol})$ was added dropwise followed by chloromethyl methyl ether $(0.49 \mathrm{~mL}, 6.5 \mathrm{mmol})$. The reaction was heated to reflux and stirred over night. Brine $(30 \mathrm{~mL})$ was added and the aqueous layer was extracted with 
dichloromethane $(30 \mathrm{~mL})$. The combined organic layers were washed with acetic acid $(2 \times 15 \mathrm{~mL}$, $10 \%)$, sat. $\mathrm{NaHCO}_{3}(15 \mathrm{~mL})$ and brine $(30 \mathrm{~mL})$, dried over anhydrous magnesium sulfate and the solvent was removed in vacuo. The product was purified by chromatography (7:3, hexane:EtOAc). Pale yellow solid (76\% yield); mp $114-115{ }^{\circ} \mathrm{C}$ (hexane:EtOAc) (lit. ${ }^{271} \mathrm{mp} 117{ }^{\circ} \mathrm{C}$ ); $R_{f}=0.25$ (hexane:EtOAc 7:3); ${ }^{1} \mathrm{H}$ NMR $\left(300 \mathrm{MHz}, \mathrm{CDCl}_{3}\right) \delta=6.88(\mathrm{~s}, 1 \mathrm{H}), 6.83(\mathrm{~s}, 1 \mathrm{H}), 5.19(\mathrm{~s}, 2 \mathrm{H}), 3.85$ $(\mathrm{s}, 3 \mathrm{H}), 3.51(\mathrm{~s}, 3 \mathrm{H}), 2.89-2.78(\mathrm{~m}, 2 \mathrm{H}), 2.50(\mathrm{dd}, J=18.4,8.4 \mathrm{~Hz}, 1 \mathrm{H}), 2.43-1.91(\mathrm{~m}, 6 \mathrm{H}), 1.70$ $-1.31(\mathrm{~m}, 7 \mathrm{H}), 0.91(\mathrm{~s}, 3 \mathrm{H}) ;{ }^{13} \mathrm{C} \mathrm{NMR}\left(75 \mathrm{MHz}, \mathrm{CDCl}_{3}\right) \delta=147.71,144.50,133.45,128.73$, 116.82 , 109.28, 95.47, 56.10, 56.01, 50.36, 47.94, 44.30, 38.22, 35.83, 31.58, 28.90, 26.58, 26.05, $21.52,13.83$.

\subsection{3 ortho-Formylation products}

\section{General procedure for ortho-formylation of phenols}

To a dry THF solution $(10 \mathrm{~mL})$ of the phenol $(1 \mathrm{mmol})$, anhydrous magnesium chloride $(0.19 \mathrm{~g}, 2$ mmol), triethylamine $(0.20 \mathrm{~g}, 2 \mathrm{mmol})$, paraformaldehyde $(90 \mathrm{mg}, 3 \mathrm{mmol})$ were added. The reaction mixture was heated to reflux under an argon atmosphere for 1-4 h, and monitored by TLC (hexane:EtOAc, 8:2). After complete consumption of the phenol, the reaction mixture was cooled and diluted with $\mathrm{Et}_{2} \mathrm{O}(20 \mathrm{~mL})$. The organic layer was washed successively with $\mathrm{HCl}(1 \mathrm{M}, 2 \mathrm{x} 10$ $\mathrm{mL})$ and water $(2 \mathrm{x} 10 \mathrm{~mL})$, and then dried $\left(\mathrm{MgSO}_{4}\right)$. The product was purified by column chromatography using hexane:EtOAc (95:5 to 70:30).

3-Allyl-2-hydroxybenzaldehyde (105). Pale yellow oil (78\%); $\mathrm{R}_{\mathrm{f}}=0.31$ (95:5, hexane:EtOAc); ${ }^{1} \mathrm{H}$ $\operatorname{NMR}\left(300 \mathrm{MHz}, \mathrm{CDCl}_{3}\right) \delta=11.28(\mathrm{~s}, 1 \mathrm{H}), 9.87(\mathrm{~s}, 1 \mathrm{H}), 7.45-7.35(\mathrm{~m}, 2 \mathrm{H}), 6.95(\mathrm{t}, J=7.6,1 \mathrm{H})$, 6.06 - $5.89(\mathrm{~m}, 1 \mathrm{H}), 5.13-5.02(\mathrm{~m}, 2 \mathrm{H}), 3.41(\mathrm{dd}, J=5.1,8.5,2 \mathrm{H}) ;{ }^{13} \mathrm{C} \mathrm{NMR}\left(75 \mathrm{MHz}, \mathrm{CDCl}_{3}\right) \delta$ $=196.67,159.49,137.09,135.73,131.85,128.77,120.25,119.53,116.21,33.00$.

3-Ethyl-2-hydroxybenzaldehyde (106). Colourless oil (71\%); $\mathrm{R}_{\mathrm{f}}=0.68$ (9:1, hexane:EtOAc); ${ }^{1} \mathrm{H}$ $\operatorname{NMR}\left(300 \mathrm{MHz}, \mathrm{CDCl}_{3}\right) \delta=11.29(\mathrm{~s}, 1 \mathrm{H}), 9.87(\mathrm{~s}, 1 \mathrm{H}), 7.40(\mathrm{dt}, J=4.3,1.9 \mathrm{~Hz}, 2 \mathrm{H}), 6.95(\mathrm{t}, J=$ $7.6 \mathrm{~Hz}, 1 \mathrm{H}), 2.70(\mathrm{q}, J=7.5 \mathrm{~Hz}, 2 \mathrm{H}), 1.23(\mathrm{t}, J=7.5 \mathrm{~Hz}, 3 \mathrm{H}) ;{ }^{13} \mathrm{C} \mathrm{NMR}\left(75 \mathrm{MHz}, \mathrm{CDCl}_{3}\right) \delta=$ $196.75,159.61,136.19,132.66,131.31,120.06,119.45,22.17,13.61$.

2-Hydroxy-3-propylbenzaldehyde (107). Colourless oil (85\%); $\mathrm{R}_{\mathrm{f}}=0.34$ (95:5, hexane:EtOAc); ${ }^{1} \mathrm{H}$ NMR $\left(300 \mathrm{MHz}, \mathrm{CDCl}_{3}\right) \delta=11.25(\mathrm{~d}, J=0.5,1 \mathrm{H}), 9.86(\mathrm{~s}, 1 \mathrm{H}), 7.47-7.27(\mathrm{~m}, 2 \mathrm{H}), 6.92(\mathrm{t}, J$ $=7.6,1 \mathrm{H}), 2.73-2.49(\mathrm{~m}, 2 \mathrm{H}), 1.63(\mathrm{dq}, J=7.4,14.8,2 \mathrm{H}), 0.94(\mathrm{t}, J=7.4,3 \mathrm{H}) ;{ }^{13} \mathrm{C} \mathrm{NMR}(75$ $\left.\mathrm{MHz}, \mathrm{CDCl}_{3}\right) \delta=196.77,159.79,137.14,131.45,131.22,120.19,119.33,31.09,22.49,13.90$. 
2-Hydroxy-3-isopropylbenzaldehyde (108). Colourless oil (63\%); $\mathrm{R}_{\mathrm{f}}=0.50$ (9:1, hexane:EtOAc); ${ }^{1} \mathrm{H}$ NMR $\left(300 \mathrm{MHz}, \mathrm{CDCl}_{3}\right) \delta=11.38(\mathrm{~s}, 1 \mathrm{H}), 9.88(\mathrm{~s}, 1 \mathrm{H}), 7.47(\mathrm{dd}, J=7.5,1.6 \mathrm{~Hz}, 1 \mathrm{H}), 7.40$ $(\mathrm{dd}, J=7.7,1.7 \mathrm{~Hz}, 1 \mathrm{H}), 6.99$ (t, $J=7.6 \mathrm{~Hz}, 1 \mathrm{H}), 3.47-3.29(\mathrm{~m}, 1 \mathrm{H}), 1.26(\mathrm{~s}, 3 \mathrm{H}), 1.24(\mathrm{~s}, 3 \mathrm{H})$; ${ }^{13} \mathrm{C}$ NMR $\left(75 \mathrm{MHz}, \mathrm{CDCl}_{3}\right) \delta=196.89,159.18,137.04,133.60,131.26,120.10,119.55,26.17$, 22.23

3-tert-Butyl-2-hydroxybenzaldehyde (109). Colourless oil (71\%); $\mathrm{R}_{\mathrm{f}}=0.73 \quad(95: 5$, hexane:EtOAc); ${ }^{1} \mathrm{H} \mathrm{NMR}\left(300 \mathrm{MHz}, \mathrm{CDCl}_{3}\right) \delta=11.77(\mathrm{~s}, 1 \mathrm{H}), 9.86(\mathrm{~s}, 1 \mathrm{H}), 7.51$ (dd, $J=1.4,7.7$, $1 \mathrm{H}), 7.38(\mathrm{dd}, J=1.7,7.7,1 \mathrm{H}), 6.93(\mathrm{t}, J=7.7,1 \mathrm{H}), 1.40(\mathrm{~s}, 9 \mathrm{H}) ;{ }^{13} \mathrm{C} \mathrm{NMR}\left(75 \mathrm{MHz}, \mathrm{CDCl}_{3}\right) \delta=$ 197.14, 161.17, 138.16, 134.09, 131.96, 120.57, 119.17, 34.82, 29.15.

2-Hydroxy-3-phenyl-benzaldehyde (110). Yellow solid (84\%); mp 47-48 ${ }^{\circ} \mathrm{C}$ (EtOAc) (lit. ${ }^{167} 47-$ $\left.48{ }^{\circ} \mathrm{C}\right) ; \mathrm{R}_{\mathrm{f}}=0.56\left(95: 5\right.$, hexane:EtOAc); ${ }^{1} \mathrm{H}$ NMR $\left(300 \mathrm{MHz}, \mathrm{CDCl}_{3}\right) \delta=11.56(\mathrm{~s}, 1 \mathrm{H}), 9.96(\mathrm{~s}$, 1H), $7.61(\mathrm{~m}, 4 \mathrm{H}), 7.47(\mathrm{~m}, 2 \mathrm{H}), 7.39(\mathrm{~m}, 1 \mathrm{H}), 7.12(\mathrm{t}, J=7.6 \mathrm{~Hz}, 1 \mathrm{H}) ;{ }^{13} \mathrm{C} \mathrm{NMR}(75 \mathrm{MHz}$, $\left.\mathrm{CDCl}_{3}\right) \delta=196.82,158.82,137.77,136.22,133.16,130.40,129.21,128.25,127.63,120.79$, 119.89 .

3-Cyclopentyl-2-hydroxybenzaldehyde (111). Colourless oil (82\%); $\mathrm{R}_{\mathrm{f}}=0.45$ (95:5, hexane:EtOAc); ${ }^{1} \mathrm{H}$ NMR $\left(300 \mathrm{MHz}, \mathrm{CDCl}_{3}\right) \delta=11.38(\mathrm{~s}, 1 \mathrm{H}), 9.88$ (s, 1H), 7.47 (dd, $J=7.5,1.6$ $\mathrm{Hz}, 1 \mathrm{H}), 7.38$ (dd, $J=7.7,1.7 \mathrm{~Hz}, 1 \mathrm{H}), 6.96$ (t, $J=7.6 \mathrm{~Hz}, 1 \mathrm{H}), 3.38(\mathrm{~m}, 1 \mathrm{H}), 2.07$ (m, 2H), 1.70 $(\mathrm{m}, 6 \mathrm{H}) ;{ }^{13} \mathrm{C} \mathrm{NMR}\left(75 \mathrm{MHz}, \mathrm{CDCl}_{3}\right) \delta=196.83,159.79,134.82,134.18,131.21,120.11,119.43$, $38.33,32.63,25.35$.

3-Cyclohexyl-2-hydroxybenzaldehyde (112). Colourless solid (73\%); mp 45-46 ${ }^{\circ} \mathrm{C}$; $\mathrm{R}_{\mathrm{f}}=0.45$ (95:5, hexane:EtOAc); ${ }^{1} \mathrm{H}$ NMR $\left(300 \mathrm{MHz}, \mathrm{CDCl}_{3}\right) \delta=11.39(\mathrm{~s}, 1 \mathrm{H}), 9.88(\mathrm{~s}, 1 \mathrm{H}), 7.45(\mathrm{dd}, J=$ 7.5, 1.6 Hz, 1H), 7.39 (dd, $J=7.7,1.7 \mathrm{~Hz}, 1 \mathrm{H}), 6.98(\mathrm{t}, J=7.6 \mathrm{~Hz}, 1 \mathrm{H}), 3.01(\mathrm{tt}, J=11.2,2.9 \mathrm{~Hz}$, $1 \mathrm{H}), 1.81(\mathrm{~m}, 5 \mathrm{H}), 1.36(\mathrm{~m}, 5 \mathrm{H}) ;{ }^{13} \mathrm{C} \mathrm{NMR}\left(75 \mathrm{MHz}, \mathrm{CDCl}_{3}\right) \delta=196.91,159.16,136.26,134.10$, $131.19,120.08,119.56,36.09,32.76,26.84,26.25$.

3-Benzyl-2-hydroxybenzaldehyde (113). Pale yellow solid (70\%); mp 33-34 ${ }^{\circ} \mathrm{C} ; \mathrm{R}_{\mathrm{f}}=0.50(95: 5$, hexane:EtOAc); ${ }^{1} \mathrm{H}$ NMR $\left(300 \mathrm{MHz}, \mathrm{CDCl}_{3}\right) \delta=11.37$ (s, 1H), 9.89 (s, 1H), 7.44 (dd, $J=7.7,1.6$ $\mathrm{Hz}, 1 \mathrm{H}), 7.28(\mathrm{~m}, 6 \mathrm{H}), 6.95(\mathrm{t}, J=7.6 \mathrm{~Hz}, 1 \mathrm{H}), 4.04(\mathrm{~s}, 2 \mathrm{H}) ;{ }^{13} \mathrm{C} \mathrm{NMR}\left(75 \mathrm{MHz}, \mathrm{CDCl}_{3}\right) \delta=$ $196.66,159.49,139.83,137.48,131.93,129.94,128.93,128.43,126.16,120.30,119.53,34.75$. 
3,5-di-tert-Butyl-2-hydroxybenzaldehyde (114). Colourless solid (55\%); mp 59-61 ${ }^{\circ} \mathrm{C}$ (lit. ${ }^{272} \mathrm{mp}$ 61-63 $\left.{ }^{\circ} \mathrm{C}(\mathrm{EtOH})\right) ; \mathrm{R}_{\mathrm{f}}=0.76\left(95: 5\right.$, hexane:EtOAc); ${ }^{1} \mathrm{H}$ NMR $(300 \mathrm{MHz}, \mathrm{CDCl} 3) \delta 11.64(\mathrm{~s}, 1 \mathrm{H})$, $9.86(\mathrm{~s}, 1 \mathrm{H}), 7.58(\mathrm{~d}, J=2.3,1 \mathrm{H}), 7.34(\mathrm{~d}, J=2.4,1 \mathrm{H}), 1.41(\mathrm{~s}, 9 \mathrm{H}), 1.31(\mathrm{~s}, 9 \mathrm{H}) ;{ }^{13} \mathrm{C}$ NMR $(75$ $\mathrm{MHz}, \mathrm{CDCl} 3) \delta 197.79,159.49,142.01,137.96,132.33,128.27,120.36,35.43,34.66,31.74$, 29.67 .

2-Hydroxy-1-naphthaldehyde (115). Yellow solid (49\%); mp 78-79 ${ }^{\circ} \mathrm{C}\left(\right.$ lit. $\left.^{273} \mathrm{mp} 79{ }^{\circ} \mathrm{C}\right)$; $\mathrm{R}_{\mathrm{f}}=$ 0.29 (9:1, hexane:EtOAc); ${ }^{1} \mathrm{H}$ NMR $\left(300 \mathrm{MHz}, \mathrm{CDCl}_{3}\right) \delta 13.14(\mathrm{~s}, 1 \mathrm{H}), 10.80(\mathrm{~s}, 1 \mathrm{H}), 8.33(\mathrm{~d}, J=$ $8.5,1 \mathrm{H}), 7.96(\mathrm{~d}, J=9.1,1 \mathrm{H}), 7.79(\mathrm{~d}, J=8.1,1 \mathrm{H}), 7.60(\mathrm{ddd}, J=1.4,7.0,8.5,1 \mathrm{H}), 7.42(\mathrm{ddd}, J=$ 1.0, 7.0, 8.0, 1H), $7.13(\mathrm{~d}, J=9.1,1 \mathrm{H}) ;{ }^{13} \mathrm{C} \mathrm{NMR}\left(75 \mathrm{MHz}, \mathrm{CDCl}_{3}\right) \delta 193.16,164.82,139.05$, $132.76,129.39,129.03,127.68,124.42,119.07,118.50,111.16$.

4-Hydroxybenzo $[d][1,3]$ dioxole-5-carbaldehyde (116). Colourless solid (97\%); mp 113-115 ${ }^{\circ} \mathrm{C}$ (lit. $\left.{ }^{177} \mathrm{mp} \mathrm{113-115}{ }^{\circ} \mathrm{C}\right) ; \mathrm{R}_{\mathrm{f}}=0.62\left(7: 3\right.$, hexane:EtOAc); ${ }^{1} \mathrm{H}$ NMR $\left(200 \mathrm{MHz}, \mathrm{CDCl}_{3}\right): \delta=10.97$ (s, 1H), $9.71(\mathrm{~s}, 1 \mathrm{H}), 7.14(\mathrm{~d}, J=8.2 \mathrm{~Hz}, 1 \mathrm{H}), 6.56(\mathrm{~d}, J=8.2 \mathrm{~Hz}, 1 \mathrm{H}), 6.08(\mathrm{~s}, 1 \mathrm{H}) .{ }^{13} \mathrm{C}$ NMR $(75$ $\left.\mathrm{MHz}_{\mathrm{CDCl}}\right): \delta=195.06,155.13,145.49,134.10,30.43,118.25,102.80,101.95$.

4-Formyl-3-hydroxyphenol acetate (136). Colourless solid $(20 \%)$; mp $48-49{ }^{\circ} \mathrm{C}\left(\mathrm{CHCl}_{3}\right)\left(\mathrm{lit}^{274}\right.$ 49-50 (EtOH)); $\mathrm{R}_{\mathrm{f}}=0.38\left(9: 1\right.$, hexane:EtOAc); ${ }^{1} \mathrm{H}$ NMR (300 MHz, $\left.\mathrm{CDCl}_{3}\right): \delta=11.19(\mathrm{~s}, 1 \mathrm{H})$, $9.82(\mathrm{~s}, 1 \mathrm{H}), 7.55(\mathrm{~d}, J=8.2 \mathrm{~Hz}, 1 \mathrm{H}), 6.75(\mathrm{~m}, 2 \mathrm{H}), 2.29(\mathrm{~s}, 3 \mathrm{H}) ;{ }^{13} \mathrm{C} \mathrm{NMR}\left(75 \mathrm{MHz}, \mathrm{CDCl}_{3}\right): \delta=$ $170.70,156.75,151.17,129.99,113.31,113.19,109.05,21.04$.

4-Formyl-3-hydroxyphenol pivalate (137). Colourless solid (40\%); mp 63-64 ${ }^{\circ} \mathrm{C}$ (hexane); $\mathrm{R}_{\mathrm{f}}=$ 0.38 (8:2, hexane:EtOAc); ${ }^{1} \mathrm{H}$ NMR $\left(200 \mathrm{MHz} \mathrm{CDCl}_{3}\right): \delta=11.18$ (s, 1H), $9.82(\mathrm{~s}, 1 \mathrm{H}), 7.53$ (dd, $J$ $=8.2,0.5 \mathrm{~Hz}, 1 \mathrm{H}), 6.72(\mathrm{~m}, 2 \mathrm{H}), 1.33(\mathrm{~s}, 9 \mathrm{H}) ;{ }^{13} \mathrm{C} \mathrm{NMR}\left(50 \mathrm{MHz}, \mathrm{CDCl}_{3}\right): \delta=195.41,176.03$, $163.10,157.90,134.84,118.51,113.85,110.58,39.26,26.97$.

tert-Butyl 4-formyl-3-hydroxyphenyl carbonate (138). Colourless solid (30\%); mp 72-73 ${ }^{\circ} \mathrm{C}$ (hexane); $\mathrm{R}_{\mathrm{f}}=0.43$ (7:3, hexane:EtOAc); ${ }^{1} \mathrm{H}$ NMR (200 MHz, $\left.\mathrm{CDCl}_{3}\right): \delta=11.19(\mathrm{~s}, 1 \mathrm{H}), 9.83(\mathrm{~s}$, $1 \mathrm{H}), 7.54(\mathrm{dd}, J=7.8,1.1 \mathrm{~Hz}, 1 \mathrm{H}), 6.84(\mathrm{~m}, 2 \mathrm{H}), 1.54(\mathrm{~s}, 9 \mathrm{H}) ;{ }^{13} \mathrm{C} \mathrm{NMR}\left(50 \mathrm{MHz}, \mathrm{CDCl}_{3}\right) \delta=$ 195.37, 163.06, 157.47, 150.39, 134.88, 118.43, 113.30, 110.08, 84.45, 27.56. 
4-((2,3-Dimethylbutan-2-yl)dimethylsilyloxy)-2-hydroxybenzaldehyde (139). Brown oil (66 \%); $\mathrm{R}_{\mathrm{f}}=0.38$ (9:1, hexane:EtOAc); ${ }^{1} \mathrm{H}$ NMR $\left(300 \mathrm{MHz}, \mathrm{CDCl}_{3}\right) \delta=11.31(\mathrm{~s}, 1 \mathrm{H}), 9.69$ (s, 1H), 7.37 $(\mathrm{d}, J=8.5,1 \mathrm{H}), 6.44(\mathrm{dd}, J=2.2,8.5,1 \mathrm{H}), 6.36(\mathrm{~d}, J=2.1,1 \mathrm{H}), 1.75-1.62(\mathrm{~m}, 1 \mathrm{H}), 0.91(\mathrm{~d}, J=$ 7.0, 13H), $0.27(\mathrm{~s}, 6 \mathrm{H}) ;{ }^{13} \mathrm{C} \mathrm{NMR}\left(75 \mathrm{MHz}, \mathrm{CDCl}_{3}\right) \delta=194.46,164.05,163.60,135.37,115.75$, $113.10,107.65,34.00,25.12,19.97,18.46,-2.42$.

2-Hydroxy-4,6-dimethoxybenzaldehyde (156b). Colourless solid $(21 \%)$; mp $70-71{ }^{\circ} \mathrm{C}\left(\mathrm{CHCl}_{3}\right)$ (lit. $\left.{ }^{275} \mathrm{mp} 71{ }^{\circ} \mathrm{C}\right) ; \mathrm{R}_{\mathrm{f}}=0.48\left(6: 4\right.$, hexane:EtOAc); ${ }^{1} \mathrm{H}$ NMR $\left(300 \mathrm{MHz}, \mathrm{CDCl}_{3}\right) \delta=12.49(\mathrm{~s}, 1 \mathrm{H})$, $10.07(\mathrm{~s}, 1 \mathrm{H}), 6.00(\mathrm{~d}, J=2.1 \mathrm{~Hz}, 1 \mathrm{H}), 5.89(\mathrm{~d}, J=1.9 \mathrm{~Hz}, 1 \mathrm{H}), 3.82(\mathrm{~s}, 3 \mathrm{H}), 3.80(\mathrm{~s}, 3 \mathrm{H}) ;{ }^{13} \mathrm{C}$ $\operatorname{NMR}\left(75 \mathrm{MHz}, \mathrm{CDCl}_{3}\right) \delta=191.76,168.08,166.26,163.48,105.94,92.86,90.48,55.65,55.63$.

\subsubsection{PAC-1 derivatives}

\section{General procedure for the synthesis of PAC-1 analogues}

A $100 \mathrm{~mL}$ round-bottom flask was charged with salicylaldehyde (1 mmol, 1 eqv.) and EtOH (10 $\mathrm{mL})$. To the stirring solution (4-Benzylpiperazino)acetic acid hydrazide (120, $1.1 \mathrm{mmol})$ and $12 \mathrm{M}$ $\mathrm{HCl}(10 \mu \mathrm{L}$ in $40 \mathrm{~mL}$ of EtOH$)$ were added. The reaction was heated at reflux for $48 \mathrm{hrs}$. The reaction mixture was cooled and then concentrated via rotary evaporation and crystallized from EtOH/hexane. Reactions were monitored by TLC on RP-18 $\mathrm{F}_{254 \mathrm{~s}}$ plates (Merck).

(E)-2-(4-Benzylpiperazin-1-yl)- $N$ '-(3-ethyl-2-hydroxybenzylidene)acetohydrazide

(121).

Colourless solid (>25\%); mp 118-119 ${ }^{\circ} \mathrm{C}$ (hexane); $\mathrm{R}_{\mathrm{f}}=0.37$ (9:1, ACN:MeOH); ${ }^{1} \mathrm{H}$ NMR $(300$ $\left.\mathrm{MHz}, \mathrm{CDCl}_{3}\right) \delta=11.19(\mathrm{~s}, 1 \mathrm{H}), 10.01(\mathrm{~s}, 1 \mathrm{H}), 8.42(\mathrm{~s}, 1 \mathrm{H}), 7.38-7.27(\mathrm{~m}, 5 \mathrm{H}), 7.20(\mathrm{dd}, J=7.4$, $1.1 \mathrm{~Hz}, 1 \mathrm{H}), 7.06(\mathrm{dd}, J=7.7,1.6 \mathrm{~Hz}, 1 \mathrm{H}), 6.84(\mathrm{t}, J=7.5 \mathrm{~Hz}, 1 \mathrm{H}), 3.56$ (s, 2H), 3.19 (s, 2H), 2.72 $(\mathrm{q}, J=7.5 \mathrm{~Hz}, 2 \mathrm{H}), 2.67-2.42(\mathrm{~m}, 8 \mathrm{H}), 1.23(\mathrm{t}, J=7.5 \mathrm{~Hz}, 3 \mathrm{H}) ;{ }^{13} \mathrm{C} \mathrm{NMR}\left(75 \mathrm{MHz}, \mathrm{CDCl}_{3}\right) \delta=$ $165.71,156.49,151.40,132.20,131.46,129.14,128.63,128.29,127.25,118.92,116.62,62.77$, 60.89, 53.57, 52.90, 22.90, 13.82. HRMS calcd. for $\mathrm{C}_{22} \mathrm{H}_{28} \mathrm{~N}_{4} \mathrm{O}_{2}\left(\mathrm{M}^{+}\right): 380.2212$, found: 380.2209 .

\section{(E)-2-(4-Benzylpiperazin-1-yl)- $\boldsymbol{N}^{\prime}$-(2-hydroxy-3-propylbenzylidene)acetohydrazide}

(122).

Colourless solid (56\%); mp $134-135{ }^{\circ} \mathrm{C}$ (hexane); $\mathrm{R}_{\mathrm{f}}=0.66$ (8:2:0.1, $\left.\mathrm{ACN}: \mathrm{MeOH}: \mathrm{CH}_{3} \mathrm{COOH}\right) ;{ }^{1} \mathrm{H}$ $\operatorname{NMR}\left(200 \mathrm{MHz}, \mathrm{CDCl}_{3}\right) \delta=11.19(\mathrm{~s}, 1 \mathrm{H}), 10.02(\mathrm{~s}, 1 \mathrm{H}), 8.41(\mathrm{~s}, 1 \mathrm{H}), 7.42-7.27(\mathrm{~m}, 5 \mathrm{H}), 7.17$ (dd, $J=7.4,1.3 \mathrm{~Hz}, 1 \mathrm{H}), 7.06(\mathrm{dd}, J=7.7,1.6 \mathrm{~Hz}, 1 \mathrm{H}), 6.83(\mathrm{t}, J=7.5 \mathrm{~Hz}, 1 \mathrm{H}), 3.56(\mathrm{~s}, 2 \mathrm{H}), 3.19$ (s, 2H), $2.88-2.39(\mathrm{~m}, 11 \mathrm{H}), 1.85-1.49(\mathrm{~m}, 2 \mathrm{H}), 0.96(\mathrm{t}, J=7.3 \mathrm{~Hz}, 3 \mathrm{H}) ;{ }^{13} \mathrm{C}$ NMR $(75 \mathrm{MHz}$, $\left.\mathrm{CDCl}_{3}\right) \delta=165.67,156.62,151.46,132.41,130.67,129.17,128.72,128.31,127.30,118.78$, $116.68,100.49,62.75,60.87,53.52,52.88,31.84,22.61,14.01$; HRMS calcd. for $\mathrm{C}_{23} \mathrm{H}_{30} \mathrm{~N}_{4} \mathrm{O}_{2}\left(\mathrm{M}^{+}\right)$: 
394.2369, found: 394.2365 .

(E)-2-(4-Benzylpiperazin-1-yl)- $N$ '-(2-hydroxy-3-isopropylbenzylidene)acetohydrazide (123). Colourless solid (48\%); mp 138-139 ${ }^{\circ} \mathrm{C}$ (hexane); $\mathrm{R}_{\mathrm{f}}=0.37$ (9:1, ACN:MeOH); ${ }^{1} \mathrm{H}$ NMR (300 $\left.\mathrm{MHz}, \mathrm{CDCl}_{3}\right) \delta=11.28(\mathrm{~s}, 1 \mathrm{H}), 10.04(\mathrm{~s}, 1 \mathrm{H}), 8.40(\mathrm{~s}, 1 \mathrm{H}), 7.39-7.22(\mathrm{~m}, 7 \mathrm{H}), 7.06(\mathrm{dd}, J=7.7$, $1.5 \mathrm{~Hz}, 1 \mathrm{H}), 6.87(\mathrm{t}, J=7.6 \mathrm{~Hz}, 1 \mathrm{H}), 3.57(\mathrm{~s}, 2 \mathrm{H}), 3.48-3.34(\mathrm{~m}, 1 \mathrm{H}), 3.20(\mathrm{~s}, 2 \mathrm{H}), 2.80-2.42(\mathrm{~m}$, $8 \mathrm{H}), 1.26(\mathrm{~s}, 3 \mathrm{H}), 1.24(\mathrm{~s}, 3 \mathrm{H}) ;{ }^{13} \mathrm{C} \mathrm{NMR}\left(75 \mathrm{MHz}, \mathrm{CDCl}_{3}\right) \delta=165.68,156.03,151.57,136.51$, $129.18,128.69,128.51,128.31,127.31,118.99,116.63,62.75,60.86,53.51,52.87,26.63,22.32$; HRMS calcd. for $\mathrm{C}_{23} \mathrm{H}_{30} \mathrm{~N}_{4} \mathrm{O}_{2}\left(\mathrm{M}^{+}\right)$: 394.2369, found: 394.237.

(E)-2-(4-Benzylpiperazin-1-yl)- $N$ '-(3-tert-butyl-2-hydroxybenzylidene)acetohydrazide (124). Colourless fluffy solid (61\%); $\mathrm{mp} \quad 180-181{ }^{\circ} \mathrm{C}$ (hexane); $\mathrm{R}_{\mathrm{f}}=0.70$ (9:1:0.1, ACN:MeOH:CH$\left.{ }_{3} \mathrm{COOH}\right) ;{ }^{1} \mathrm{H}$ NMR $\left(300 \mathrm{MHz}, \mathrm{CDCl}_{3}\right) \delta=11.53(\mathrm{~s}, 1 \mathrm{H}), 10.01(\mathrm{~s}, 1 \mathrm{H}), 8.41(\mathrm{~s}$, 1H), $7.38-7.27$ (m, 6H), 7.07 (dd, $J=7.6,1.5 \mathrm{~Hz}, 1 \mathrm{H}), 6.84$ (t, $J=7.7 \mathrm{~Hz}, 1 \mathrm{H}), 3.56$ (s, 2H), 3.20 $(\mathrm{s}, 2 \mathrm{H}), 2.77-2.45(\mathrm{~m}, 8 \mathrm{H}), 1.44(\mathrm{~s}, 9 \mathrm{H}) ;{ }^{13} \mathrm{C} \mathrm{NMR}\left(75 \mathrm{MHz}, \mathrm{CDCl}_{3}\right) \delta=165.69,157.83,151.91$, 137.62, 129.27, 129.12, 128.28, 127.24, 118.57, 117.13, 62.78, 60.89, 53.58, 52.92, 34.90, 29.30; HRMS calcd. for $\mathrm{C}_{24} \mathrm{H}_{32} \mathrm{~N}_{4} \mathrm{O}_{2}\left(\mathrm{M}^{+}\right)$: 408.2525, found: 408.2510 .

\section{(E)-2-(4-Benzylpiperazin-1-yl)- $N^{\prime}$-(3,5-di-tert-butyl-2-hydroxybenzylidene)acetohydrazide}

(125). Colourless fluffy solid (52\%); $\mathrm{mp}$ 193-194 ${ }^{\circ} \mathrm{C}$ (hexane); $\mathrm{R}_{\mathrm{f}}=0.52$ (9:1:0.1, ACN:MeOH:CH$\left.{ }_{3} \mathrm{COOH}\right) ;{ }^{1} \mathrm{H}$ NMR $\left(300 \mathrm{MHz}, \mathrm{CDCl}_{3}\right) \delta=11.32(\mathrm{~s}, 1 \mathrm{H}), 9.99(\mathrm{~s}, 1 \mathrm{H}), 8.44$ (s, $1 \mathrm{H}), 7.38(\mathrm{~d}, J=2.3 \mathrm{~Hz}, 1 \mathrm{H}), 7.31(\mathrm{dt}, J=4.4,2.8 \mathrm{~Hz}, 5 \mathrm{H}), 7.05(\mathrm{~d}, J=2.4 \mathrm{~Hz}, 1 \mathrm{H}), 3.56(\mathrm{~s}, 2 \mathrm{H})$, $3.19(\mathrm{~s}, 2 \mathrm{H}), 2.68-2.49(\mathrm{~m}, 8 \mathrm{H}), 1.44(\mathrm{~s}, 9 \mathrm{H}), 1.30(\mathrm{~s}, 9 \mathrm{H}) ;{ }^{13} \mathrm{C} \mathrm{NMR}\left(75 \mathrm{MHz}, \mathrm{CDCl}_{3}\right) \delta=$ $165.60,155.56,152.63,140.75,136.89,129.14,128.30,127.26,126.88,125.65,116.32$, 62.79, 60.90, 53.57, 52.93, 35.10, 34.12, 31.45, 29.38; HRMS calcd. for $\mathrm{C}_{28} \mathrm{H}_{40} \mathrm{~N}_{4} \mathrm{O}_{2}\left(\mathrm{M}^{+}\right): 464.3151$, found: 464.3157 .

(E)-2-(4-Benzylpiperazin-1-yl)- $N$ '-(3-cyclopentyl-2-hydroxybenzylidene)acetohydrazide (126). Colourless solid (75\%); mp 141-142 ${ }^{\circ} \mathrm{C}$ (hexane); $\mathrm{R}_{\mathrm{f}}=0.50$ (9:1:0.1, ACN:MeOH: $\left.\mathrm{CH}_{3} \mathrm{COOH}\right) ;{ }^{1} \mathrm{H}$ $\operatorname{NMR}\left(300 \mathrm{MHz}, \mathrm{CDCl}_{3}\right) \delta=11.27(\mathrm{~s}, 1 \mathrm{H}), 10.10(\mathrm{~s}, 1 \mathrm{H}), 8.42(\mathrm{~s}, 1 \mathrm{H}), 7.38-7.22(\mathrm{~m}, 6 \mathrm{H}), 7.05$ $(\mathrm{dd}, J=7.7,1.6 \mathrm{~Hz}, 1 \mathrm{H}), 6.85(\mathrm{t}, J=7.6 \mathrm{~Hz}, 1 \mathrm{H}), 3.60(\mathrm{~s}, 2 \mathrm{H}), 3.49-3.33(\mathrm{~m}, 1 \mathrm{H}), 3.21(\mathrm{~s}, 2 \mathrm{H})$, $2.75-2.51(\mathrm{~m}, 8 \mathrm{H}), 2.14-1.97(\mathrm{~m}, 2 \mathrm{H}), 1.88-1.50(\mathrm{~m}, 6 \mathrm{H}) ;{ }^{13} \mathrm{C} \mathrm{NMR}\left(75 \mathrm{MHz}, \mathrm{CDCl}_{3}\right) \delta=$ $165.56,156.60,151.59,134.13,129.32,128.52,128.38,118.87,116.60,62.58,60.70,53.21,52.71$, 38.93, 32.56, 25.38: HRMS calcd. for $\mathrm{C}_{25} \mathrm{H}_{32} \mathrm{~N}_{4} \mathrm{O}_{2}\left(\mathrm{M}^{+}\right)$: 420.2525, found: 420.2527 . 
(E)-2-(4-Benzylpiperazin-1-yl)- $N$ '-(3-cyclohexyl-2-hydroxybenzylidene)acetohydrazide (127).

Colourless solid (56\%); mp 175-177 ${ }^{\circ} \mathrm{C}$ (hexane); $\mathrm{R}_{\mathrm{f}}=0.29$ (9:1, ACN:MeOH); ${ }^{1} \mathrm{H}$ NMR $(300$ $\left.\mathrm{MHz}, \mathrm{CDCl}_{3}\right) \delta=11.30(\mathrm{~s}, 1 \mathrm{H}), 10.01(\mathrm{~s}, 1 \mathrm{H}), 8.39(\mathrm{~s}, 1 \mathrm{H}), 7.38-7.26(\mathrm{~m}, 5 \mathrm{H}), 7.24(\mathrm{dd}, J=7.6$, $1.2 \mathrm{~Hz}, 1 \mathrm{H}), 7.04$ (dd, $J=7.7,1.6 \mathrm{~Hz}, 1 \mathrm{H}), 6.86$ (t, $J=7.6 \mathrm{~Hz}, 1 \mathrm{H}), 3.55$ (s, 2H), 3.19 (s, 2H), 3.13 $-2.99(\mathrm{~m}, 1 \mathrm{H}), 2.76-2.43(\mathrm{~m}, 8 \mathrm{H}), 1.96-1.70(\mathrm{~m}, 5 \mathrm{H}), 1.57-1.16(\mathrm{~m}, 5 \mathrm{H}) ;{ }^{13} \mathrm{C} \mathrm{NMR}(75 \mathrm{MHz}$, $\left.\mathrm{CDCl}_{3}\right) \delta=165.66,155.99,151.49,135.74,129.17,129.13,128.41,128.29,127.25,118.99$, 116.61, 62.78, 60.89, 53.57, 52.92, 36.67, 32.84, 26.97, 26.39; HRMS calcd. for $\mathrm{C}_{26} \mathrm{H}_{34} \mathrm{~N}_{4} \mathrm{O}_{2}\left(\mathrm{M}^{+}\right)$: 434.2682, found: 434.2669 .

\section{(E)-2-(4-Benzylpiperazin-1-yl)- $N$ '-(3-ethoxy-2-hydroxybenzylidene)acetohydrazide}

(128).

Colourless solid (75\%); mp 97-99 ${ }^{\circ} \mathrm{C}$ (hexane); $\mathrm{R}_{\mathrm{f}}=0.59$ (9:1:0.1, ACN:MeOH: $\left.\mathrm{CH}_{3} \mathrm{COOH}\right) ;{ }^{1} \mathrm{H}$ $\operatorname{NMR}\left(300 \mathrm{MHz}, \mathrm{CDCl}_{3}\right) \delta=10.79(\mathrm{~s}, 1 \mathrm{H}), 10.06(\mathrm{~s}, 1 \mathrm{H}), 8.49(\mathrm{~s}, 1 \mathrm{H}), 7.30(\mathrm{~m}, 5 \mathrm{H}), 6.92(\mathrm{td}, J=$ $8.1,1.7 \mathrm{~Hz}, 2 \mathrm{H}), 6.83(\mathrm{q}, J=8.2 \mathrm{~Hz}, 1 \mathrm{H}), 4.12(\mathrm{q}, J=7.0 \mathrm{~Hz}, 2 \mathrm{H}), 3.56(\mathrm{~s}, 2 \mathrm{H}), 3.19(\mathrm{~s}, 2 \mathrm{H}), 2.61$ $(\mathrm{m}, 8 \mathrm{H}), 1.46(\mathrm{t}, J=7.0 \mathrm{~Hz}, 3 \mathrm{H}) ;{ }^{13} \mathrm{C} \mathrm{NMR}\left(75 \mathrm{MHz}, \mathrm{CDCl}_{3}\right) \delta=165.86,150.76,148.48,147.42$, 137.16, 129.21, 128.29, 127.31, 122.46, 119.00, 117.76, 115.58, 64.75, 62.68, 60.85, 53.42, 52.79, 14.84; HRMS calcd. for $\mathrm{C}_{22} \mathrm{H}_{28} \mathrm{~N}_{4} \mathrm{O}_{3}\left(\mathrm{M}^{+}\right)$: 396.2161, found: 396.2170 .

\section{(E)-2-(4-Benzylpiperazin-1-yl)- $N$ '-((2-hydroxy-[1,1'-biphenyl]-3-yl)methylene)acetohydrazide}

(129). Colourless solid (57\%); $\mathrm{mp} \quad 157-158 \quad{ }^{\circ} \mathrm{C}$ (hexane); $\mathrm{R}_{\mathrm{f}}=0.79$ (7:2:0.1, ACN:MeOH:CH $3 \mathrm{COOH}) ;{ }^{1} \mathrm{H}$ NMR $\left(300 \mathrm{MHz}, \mathrm{CDCl}_{3}\right) \delta=11.47(\mathrm{~s}, 1 \mathrm{H}), 10.06(\mathrm{~s}, 1 \mathrm{H}), 8.53(\mathrm{~s}$, 1H), $7.67-7.57(\mathrm{~m}, 2 \mathrm{H}), 7.50-7.26(\mathrm{~m}, 9 \mathrm{H}), 7.22(\mathrm{dd}, J=7.7,1.6 \mathrm{~Hz}, 1 \mathrm{H}), 6.99(\mathrm{t}, J=7.6 \mathrm{~Hz}$, $1 \mathrm{H}), 3.54(\mathrm{~d}, J=16.0 \mathrm{~Hz}, 2 \mathrm{H}), 3.19(\mathrm{~s}, 2 \mathrm{H}), 2.91-2.27(\mathrm{~m}, 8 \mathrm{H}) ;{ }^{13} \mathrm{C} \mathrm{NMR}\left(75 \mathrm{MHz}, \mathrm{CDCl}_{3}\right) \delta=$ 165.82 , 155.65, 151.16, 137.70, 137.55, 132.97, 130.31, 129.89, 129.35, 129.05, 128.23, 128.01, 127.13, 127.11, 119.29, 117.55, 62.80, 60.88, 53.63, 52.92; HRMS calcd. for $\mathrm{C}_{26} \mathrm{H}_{28} \mathrm{~N}_{4} \mathrm{O}_{2}\left(\mathrm{M}^{+}\right)$: 428.2212, found: 428.2219 .

(E)-N'-(3-Benzyl-2-hydroxybenzylidene)-2-(4-benzylpiperazin-1-yl)acetohydrazide (130). Colourless solid (88\%); mp 133-135 ${ }^{\circ} \mathrm{C}$ (hexane); $\mathrm{R}_{\mathrm{f}}=0.37$ (9:1, ACN:MeOH); ${ }^{1} \mathrm{H}$ NMR $(300$ $\left.\mathrm{MHz} \mathrm{CDCl}_{3}\right) \delta=11.30(\mathrm{~s}, 1 \mathrm{H}), 10.05(\mathrm{~s}, 1 \mathrm{H}), 8.38(\mathrm{~s}, 1 \mathrm{H}), 7.50-6.97(\mathrm{~m}, 12 \mathrm{H}), 6.82(\mathrm{t}, J=7.5$ $\mathrm{Hz}, 1 \mathrm{H}), 4.05(\mathrm{~s}, 2 \mathrm{H}), 3.57(\mathrm{~s}, 2 \mathrm{H}), 3.19(\mathrm{~s}, 2 \mathrm{H}), 2.87-2.25(\mathrm{~m}, 8 \mathrm{H}) ;{ }^{13} \mathrm{C} \mathrm{NMR}\left(75 \mathrm{MHz}, \mathrm{CDCl}_{3}\right) \delta$ $=165.75,156.39,151.20,140.62,137.48,132.70,129.32,129.18,129.12,128.95,128.27,128.25$, 127.23, 125.85, 118.97, 116.91, 62.77, 60.88, 53.56, 52.89, 35.45; HRMS calcd. for $\mathrm{C}_{27} \mathrm{H}_{30} \mathrm{~N}_{4} \mathrm{O}_{2}$ $\left(\mathrm{M}^{+}\right)$: 442.2369, found: 442.2370 . 
(E)-2-(4-Benzylpiperazin-1-yl)-N'-(2-hydroxy-3-nitrobenzylidene)acetohydrazide (131). Yellow solid (62\%); mp 163-165 ${ }^{\circ} \mathrm{C}$ (hexane); $\mathrm{R}_{\mathrm{f}}=0.71$ (9:1:0.1, $\left.\mathrm{ACN}: \mathrm{MeOH}: \mathrm{CH}_{3} \mathrm{COOH}\right) ;{ }^{1} \mathrm{H}$ NMR $(300$ $\left.\mathrm{MHz}, \mathrm{CDCl}_{3}\right) \delta=10.38(\mathrm{~s}, 2 \mathrm{H}), 8.60(\mathrm{~s}, 1 \mathrm{H}), 8.15(\mathrm{dd}, J=7.7,1.0 \mathrm{~Hz}, 1 \mathrm{H}), 8.08(\mathrm{dd}, J=8.3,1.3$ $\mathrm{Hz}, 1 \mathrm{H}), 7.39-7.20(\mathrm{~m}, 5 \mathrm{H}), 7.00(\mathrm{t}, J=8.0 \mathrm{~Hz}, 1 \mathrm{H}), 3.55(\mathrm{~s}, 2 \mathrm{H}), 3.21(\mathrm{~s}, 2 \mathrm{H}), 2.78-2.42(\mathrm{~m}$, $8 \mathrm{H}) ;{ }^{13} \mathrm{C} \mathrm{NMR}\left(75 \mathrm{MHz}, \mathrm{CDCl}_{3}\right) \delta=166.53,153.21,143.25,137.66,135.09,134.99,129.06$, 128.24, 127.16, 126.92, 123.44, 119.56, 62.78, 60.94, 53.62, 52.90; HRMS calcd. for $\mathrm{C}_{20} \mathrm{H}_{23} \mathrm{~N}_{5} \mathrm{O}_{4}$ $\left(\mathrm{M}^{+}\right)$: 397.1750 , found: 397.1746 .

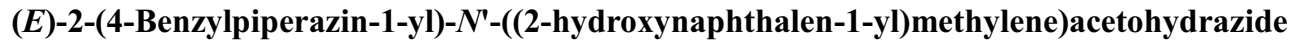

(132). Yellow solid (95\%); mp 99-101 ${ }^{\circ} \mathrm{C}$ (hexane); $\mathrm{R}_{\mathrm{f}}=0.33$ (9:1, ACN:MeOH); ${ }^{1} \mathrm{H}$ NMR $(300$ $\left.\mathrm{MHz}, \mathrm{CDCl}_{3}\right) \delta=12.37(\mathrm{~s}, 1 \mathrm{H}), 10.22(\mathrm{~s}, 1 \mathrm{H}), 9.35(\mathrm{~s}, 1 \mathrm{H}), 7.99(\mathrm{~d}, J=8.5 \mathrm{~Hz}, 1 \mathrm{H}), 7.77(\mathrm{dd}, J=$ 8.1, $4.5 \mathrm{~Hz}, 2 \mathrm{H}), 7.55-7.44(\mathrm{~m}, 1 \mathrm{H}), 7.40-7.27$ (m, 6H), $7.21(\mathrm{~d}, J=9.0 \mathrm{~Hz}, 1 \mathrm{H}), 3.59(\mathrm{~s}, 2 \mathrm{H})$, $3.24(\mathrm{~s}, 2 \mathrm{H}), 2.79-2.49(\mathrm{~m}, 8 \mathrm{H}) ;{ }^{13} \mathrm{C} \mathrm{NMR}\left(75 \mathrm{MHz}, \mathrm{CDCl}_{3}\right) \delta=165.77,159.08,147.71,137.31$, $133.15,131.98,129.18,129.07,128.29,128.04,127.40,127.29,123.41,119.81,119.35,107.77$, 62.72, 60.92, 53.53, 52.83; HRMS calcd. for $\mathrm{C}_{24} \mathrm{H}_{26} \mathrm{~N}_{4} \mathrm{O}_{2}\left(\mathrm{M}^{+}\right)$: 402,2056, found: 402.2055.

(E)-N'-(Benzo[d][1,3] dioxol-4-ylmethylene)-2-(4-benzylpiperazin-1-yl)acetohydrazide (133). Colourless solid (76\%); mp 168-169 ${ }^{\circ} \mathrm{C}$ (hexane); $\mathrm{R}_{\mathrm{f}}=0.58$ (8:2:0.1, ACN:MeOH: $\left.\mathrm{CH}_{3} \mathrm{COOH}\right) ;{ }^{1} \mathrm{H}$ $\operatorname{NMR}\left(300 \mathrm{MHz}, \mathrm{CDCl}_{3}\right) \delta=10.10(\mathrm{~s}, 1 \mathrm{H}), 8.40(\mathrm{~s}, 1 \mathrm{H}), 7.43-7.27(\mathrm{~m}, 6 \mathrm{H}), 6.90-6.81(\mathrm{~m}, 2 \mathrm{H})$, $6.05(\mathrm{~s}, 2 \mathrm{H}), 6.05(\mathrm{~s}, 2 \mathrm{H}), 3.51(\mathrm{~d}, J=18.5 \mathrm{~Hz}, 2 \mathrm{H}), 3.18(\mathrm{~s}, 2 \mathrm{H}), 2.95-2.39(\mathrm{~m}, 8 \mathrm{H}) ;{ }^{13} \mathrm{C} \mathrm{NMR}$ $\left(75 \mathrm{MHz}, \mathrm{CDCl}_{3}\right) \delta=166.27,147.84,146.41,143.34,129.05,128.23,127.14,121.74,119.62$, 116.10, 109.85, 101.45, 62.79, 61.02, 53.56, 52.94; HRMS calcd. for $\mathrm{C}_{21} \mathrm{H}_{24} \mathrm{~N}_{4} \mathrm{O}_{3}\left(\mathrm{M}^{+}\right): 380.1848$, found: 380.1864 .

(E)-2-(4-Benzylpiperazin-1-yl)- $N$ '-(2,3-dimethoxybenzylidene)acetohydrazide (134). Colourless solid (90\%); mp 139-141 ${ }^{\circ} \mathrm{C}$ (hexane); $\mathrm{R}_{\mathrm{f}}=0.63$ (9:1:0.1, ACN:MeOH: $\left.\mathrm{CH}_{3} \mathrm{COOH}\right) ;{ }^{1} \mathrm{H}$ NMR (200 $\left.\mathrm{MHz}, \mathrm{CDCl}_{3}\right) \delta=10.08(\mathrm{~s}, 1 \mathrm{H}), 8.44(\mathrm{~s}, 1 \mathrm{H}), 7.69(\mathrm{dd}, J=7.9,1.5 \mathrm{~Hz}, 1 \mathrm{H}), 7.40-7.27(\mathrm{~m}, 5 \mathrm{H})$, $7.07(\mathrm{t}, J=8.0 \mathrm{~Hz}, 1 \mathrm{H}), 6.95(\mathrm{dd}, J=8.1,1.6 \mathrm{~Hz}, 1 \mathrm{H}), 3.90(\mathrm{~s}, 3 \mathrm{H}), 3.89$ (s, 3H), 3.57 (s, 2H), 3.20 $(\mathrm{s}, 2 \mathrm{H}), 2.80-2.44(\mathrm{~m}, 8 \mathrm{H}) ;{ }^{13} \mathrm{C}$ NMR $\left(75 \mathrm{MHz}, \mathrm{CDCl}_{3}\right) \delta=166.20,152.51,148.48,143.76$, $129.12,128.26,127.19,124.21,118.64,114.09,62.78,61.73,61.04,55.76,53.58,52.91:$ HRMS calcd. for $\mathrm{C}_{22} \mathrm{H}_{28} \mathrm{~N}_{4} \mathrm{O}_{3}\left(\mathrm{M}^{+}\right)$: 396.2161, found: 396.2157 . 


\section{(E)-2-(4-Benzylpiperazin-1-yl)- $N$ '-((4-hydroxybenzo[d] [1,3]dioxol-5-yl)methylene)aceto}

hydrazide (135). Colourless solid (65\%); $\mathrm{mp}$ 120-123 ${ }^{\circ} \mathrm{C}$ (hexane); $\mathrm{R}_{\mathrm{f}}=0.46$ (9:1:0.1 ACN:MeOH:CH$\left.{ }_{3} \mathrm{COOH}\right) ;{ }^{1} \mathrm{H}$ NMR $\left(300 \mathrm{MHz}, \mathrm{CDCl}_{3}\right) \delta=10.00(\mathrm{~s}, 1 \mathrm{H}), 8.38(\mathrm{~s}, 1 \mathrm{H}), 7.28(\mathrm{~d}, J=$ $12.8 \mathrm{~Hz}, 6 \mathrm{H}), 6.75(\mathrm{~d}, J=8.1 \mathrm{~Hz}, 1 \mathrm{H}), 6.45(\mathrm{~d}, J=8.1 \mathrm{~Hz}, 1 \mathrm{H}), 6.01(\mathrm{~s}, 2 \mathrm{H}), 3.52$ (d, $J=9.0 \mathrm{~Hz}$, $2 \mathrm{H}), 3.17(\mathrm{~s}, 2 \mathrm{H}), 2.57(\mathrm{~d}, J=25.9 \mathrm{~Hz}, 8 \mathrm{H}) ;{ }^{13} \mathrm{C} \mathrm{NMR}\left(75 \mathrm{MHz}, \mathrm{CDCl}_{3}\right) \delta=165.81,151.56$, $150.92,142.80,137.44,134.40,129.11,128.22$, 127.18, 125.54, 114.11, 101.96, 100.88, 62.74, 60.85, 53.52, 52.83; HRMS calcd. for $\mathrm{C}_{21} \mathrm{H}_{24} \mathrm{~N}_{4} \mathrm{O}_{4}\left(\mathrm{M}^{+}\right)$: 396.1798, found: 396.1796.

\section{(E)-2-(4-Benzylpiperazin-1-yl)- $N$ '-(3-bromo-2,6-dihydroxybenzylidene)acetohydrazide (159).} Yellow semi solid (33\%); $\mathrm{R}_{\mathrm{f}}=0.32$ (9:1, ACN:MeOH); ${ }^{1} \mathrm{H} \mathrm{NMR}\left(300 \mathrm{MHz}, \mathrm{CD}_{3} \mathrm{OD}\right) \delta=8.76$ (s, 1H), $7.47-7.20(\mathrm{~m}, 7 \mathrm{H}), 3.84(\mathrm{~s}, 2 \mathrm{H}), 3.25(\mathrm{~s}, 2 \mathrm{H}), 2.94(\mathrm{~s}, 1 \mathrm{H}), 2.90-2.63(\mathrm{~m}, 8 \mathrm{H}) ;{ }^{13} \mathrm{C} \mathrm{NMR}$ $\left(75 \mathrm{MHz}, \mathrm{CD}_{3} \mathrm{CN}\right) \delta=166.87,157.74,155.77,146.19,138.77,135.51,129.83,128.90,127.78$, 108.51, 108.24, 100.29, 63.09, 61.29, 54.02, 53.27; MS: $m / z 447(\mathrm{M}+1)$.

\subsection{Molecular modelling}

The compounds in Figure 39 were drawn in Maestro (v. 9.8) and the structures were energy minimized using the OPLS2005 force field implemented in the Macromodel package. All molecular modelling calculations were performed using the software Autodock (v. 4.2.1), Glide (v. 5.6), Gold (v. 5.0.1) and FRED (v. 2.2.5) running on a Linux x86_64 workstation. The conformation of colchicine and podophyllotoxin structures were taken from the tubulin-ligand complex filed in the Brookhaven Protein Data Bank (entry code 1SA0 and 1SA1). The protein complexes were prepared for docking with Maestro/Macromodel (v. 9.1.207) Protein Preparation Wizard where bond orders were assigned, hydrogens added, water molecules removed, hydrogen bonds optimized and finally the protein energy minimized (convergence threshold $0.30 \mathrm{kcal} / \mathrm{mol}$ ). The native ligand was redocked into the processed protein to verify that the program in use could identify the correct binding mode of the ligand. All molecular images were prepared with Pymol (v. 1.3).

\subsubsection{Coordinate scan}

A coordinate scan was performed in gas phase with Maestro/Macromodel using OPLS2005 as the force field. The method used was Powell-Reeves conjugate gradient (PRCG) with maximum iterations 10000 , that converged on gradient with a convergence threshold of $0.0001 \mathrm{kj} / \mathrm{mol}$. The energy was calculated at different A-ring/triazole and B-ring/triazole dihedral angles. The dihedral angle $\tau_{1}$ was scanned from -60 - 300 degrees with 5 degrees increments. The dihedral angle $\tau_{2}$ was scanned from 20 - 200 degrees with 5 degrees increments. The results are summarized in Table 9. 
Table 9 The inversion barriers of the 1,5-disubstituted 1,2,3-triazole analogues. The $\tau_{1}$ and $\tau_{2}$ are the angles from the lowest energy configuration. The 4-methoxy group was within van der Waals distance from the $\pi$ electrons of the Bring.

\begin{tabular}{ccccc}
\hline Compound & $\begin{array}{c}\text { Distance 4-methoxy } \\
\text { to centre of B-ring } \AA\end{array}$ & $\tau_{1}$ & $\tau_{2}$ & $\begin{array}{c}\text { Inversion energy } \\
\text { kcal/mol }\end{array}$ \\
\hline $\mathbf{1 9}$ & 4.47 & $31^{\circ}$ & $50^{\circ}$ & 6.4 \\
$\mathbf{1 7 8}$ & 4.54 & $33^{\circ}$ & $43^{\circ}$ & 9.1 \\
$\mathbf{1 8 0}$ & 4.81 & $52^{\circ}$ & $77^{\circ}$ & 9.2 \\
$\mathbf{1 9 3}$ & 4.39 & $41^{\circ}$ & $62^{\circ}$ & 4.3 \\
$\mathbf{1 9 2}$ & 4.49 & $44^{\circ}$ & $50^{\circ}$ & 4.2 \\
$\mathbf{1 9 4}$ & 4.49 & $51^{\circ}$ & $52^{\circ}$ & 8.5 \\
$\mathbf{1 9 5}$ & 4.45 & $42^{\circ}$ & $59^{\circ}$ & 8.9 \\
$\mathbf{1 9 6}$ & 4.27 & $41^{\circ}$ & $57^{\circ}$ & 4.4 \\
$\mathbf{2 9 7}$ & 4.57 & $45^{\circ}$ & $48^{\circ}$ & $69^{\circ}$ \\
\hline
\end{tabular}

\subsubsection{Glide}

Standard parameters were used for the grid generation with Glide. A mesh of $0.375 \AA$ and $56 \times 60 \times$ 50 number of points were used to generate the grid. The grid was centred on the mass centre of the ligand coordinates. Docking in Glide was performed with standard parameters in standard precision mode. 10 poses per ligand were generated. As a standard of comparison both CA-1 (19) and CA-4 (20) and the 1,5-disubstituted-1,2,3-triazole amino analogue of CA-4 193 was docked together with the set of analogues.

\subsubsection{FRED}

The ligands were converted to the .oeb format with Omega2. The receptor grid was generated with Vida (v. 4.0.3) with a mesh of $0.375 \AA$ and $56 \times 60 \times 50$ number of points were used for the grid size. A total of six docking poses were generated and scored with Chemgauss 3 .

\subsubsection{Gold}

Receptor grid generation was performed with Gold and standard parameters were used to generate the grid with a mesh of $0.375 \AA$ and $56 \times 60 \times 50$ number of points for the grid size. GA was set to $200 \%$ for the docking of the ligands and a maximum of 100 poses were generated. 


\subsubsection{Autodock4}

A mesh of $0.375 \AA$ and $56 \times 60 \times 50$ number of points were used to generate the grid with Autogrid. The grid was centred on the mass centre of the ligand coordinates. For the docking the following parameter values were specified: maximum number of energy evaluations: 2500000, translation step/A: 1.0, quaternion step/deg: 25.0 torsion step/deg: 25.0. 100 poses were generated for each ligand.

\subsubsection{Energy minimization}

The result complexes from the Glide docking were energy minimized with Macromodel after the reinsertion of GDP and GTP that were removed with the protein preparation wizard. Minimizations were preformed using OPLS2005 as a force field (FF) in water phase. The method used was PRCG with maximum iterations 30000 , which converged on gradient with a convergence threshold of 0.01 $\mathrm{kj} / \mathrm{mol}$. 
Table 10 Docking scores

\begin{tabular}{|c|c|c|c|c|c|c|c|c|c|c|c|c|c|c|c|c|c|c|c|c|c|}
\hline \multirow{4}{*}{ 完 } & 우 & $\begin{array}{l}\bar{U} \\
\stackrel{\tilde{U}}{0} \\
\dot{0}\end{array}$ & 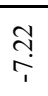 & $\stackrel{5}{i}$ & ڤे & $\underset{\substack{0 \\
i}}{0}$ & $\underset{T}{T}$ & $\frac{n}{n}$ & $\frac{m}{\stackrel{m}{r}}$ & 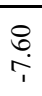 & & 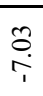 & ' & $\begin{array}{l}\mathscr{\infty} \\
\stackrel{1}{r}\end{array}$ & $\begin{array}{l}+ \\
\text { in }\end{array}$ & $\frac{0}{\pi}$ & $\begin{array}{l}8 \\
\dot{0} \\
\dot{\varphi}\end{array}$ & \begin{tabular}{l}
\multirow{7}{*}{} \\
i
\end{tabular} & $\frac{\nabla}{i}$ & $\underset{\substack{\infty \\
\varphi}}{\stackrel{\infty}{0}}$ & 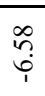 \\
\hline & 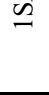 & 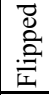 & ' & $\begin{array}{c}\hat{\sigma} \\
\text { in }\end{array}$ & $\underset{\hat{i}}{\stackrel{m}{i}}$ & $\stackrel{m}{\stackrel{0}{\varphi}}$ & $\frac{N}{\varphi_{i}^{\prime}}$ & $\begin{array}{l}\text { nे } \\
\text { î }\end{array}$ & $\frac{\vec{T}}{i}$ & 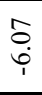 & $\frac{\text { ָे }}{i}$ & ' & ' & 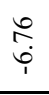 & ' & \begin{tabular}{l}
\multirow{2}{*}{} \\
$\stackrel{n}{\prime}$
\end{tabular} & ' & ' & ' & ' & ' \\
\hline & ¿ & $\begin{array}{l}\overline{0} \\
\stackrel{0}{0} \\
\text { D }\end{array}$ & $\begin{array}{l}\infty \\
0 \\
\dot{\varphi} \\
1\end{array}$ & 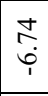 & $\stackrel{?}{\stackrel{9}{i}}$ & $\stackrel{n}{\stackrel{n}{r}}$ & $\stackrel{\grave{N}}{i}$ & $\stackrel{\circ}{\underset{T}{i}}$ & $\frac{q}{i}$ & $\begin{array}{l}\infty \\
\infty \\
\vdots \\
\varphi \\
i\end{array}$ & $\frac{\tilde{c}}{i}$ & $\frac{f}{i}$ & $\stackrel{\vec{N}}{\stackrel{T}{1}}$ & 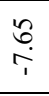 & & $\frac{2}{i}$ & 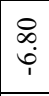 & 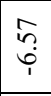 & $\begin{array}{l}\text { ț } \\
\text { ஸे }\end{array}$ & $\underset{i}{\vec{\varphi}}$ & 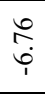 \\
\hline & $\cong$ & $\begin{array}{l}\vec{J} \\
\stackrel{\Xi}{Z} \\
:\end{array}$ & ' & ' & ' & ' & ' & ' & ' & ' & ' & ' & ' & ' & $\begin{array}{l}\text { กิ } \\
\ddot{r}\end{array}$ & & ' & ' & ' & ' & ' \\
\hline \multirow{4}{*}{ : } & 是 & $\begin{array}{l}\overrightarrow{0} \\
\text { : } \\
0\end{array}$ & $\underset{\substack{0 \\
i}}{\stackrel{\sim}{0}}$ & $\prod_{\substack{\infty \\
\infty}}$ & $\underset{\infty}{\stackrel{\sim}{\infty}}$ & $\begin{array}{l}\text { N̦ } \\
\infty \\
i\end{array}$ & 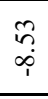 & 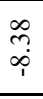 & $\underset{\substack{0 \\
\infty}}{\stackrel{0}{0}}$ & $\begin{array}{c}\hat{\infty} \\
\stackrel{T}{1}\end{array}$ & $\frac{+}{\stackrel{5}{r}}$ & $\frac{n}{\infty}$ & 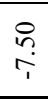 & 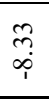 & ' & $\underset{\substack{\infty \\
i}}{ \pm}$ & ' & $\begin{array}{l}0 \\
\infty \\
\dot{T}\end{array}$ & 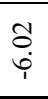 & @̊ & $\hat{\tilde{\gamma}}$ \\
\hline & $\cong$ & 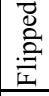 & $\stackrel{0}{i}$ & ' & 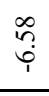 & 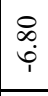 & \begin{tabular}{l}
\multirow{J}{0}{} \\
$\dot{\varphi}$ \\
$i$
\end{tabular} & $\begin{array}{l}\mathscr{\infty} \\
\stackrel{1}{T}\end{array}$ & $\stackrel{\stackrel{\sim}{T}}{T}$ & 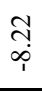 & $\stackrel{\text { }}{\grave{1}}$ & $\frac{8}{1}$ & $\underset{T}{\stackrel{0}{T}}$ & $\frac{8}{i}$ & $\bar{~}$ & $\frac{\overbrace{}}{\stackrel{1}{1}}$ & ' & ' & ' & ' & ' \\
\hline & Z & $\begin{array}{l} \\
\tilde{U} \\
\tilde{\Xi} \\
0\end{array}$ & $\begin{array}{l}\infty \\
0 \\
\infty \\
\infty \\
1\end{array}$ & $\frac{d}{i}$ & $\underset{\substack{\infty \\
\infty}}{m}$ & $\underset{\substack{0 \\
i \\
i}}{\stackrel{0}{0}}$ & $\begin{array}{l}2 \\
\infty \\
\infty \\
\infty \\
1\end{array}$ & f̊ & $\begin{array}{l}8 \\
\text { i }\end{array}$ & 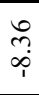 & 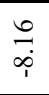 & $\begin{array}{l}\infty \\
\infty \\
\infty \\
\infty \\
1\end{array}$ & $\frac{8}{i}$ & $\frac{n}{\infty}$ & ' & $\begin{array}{l}n \\
n \\
\infty \\
1\end{array}$ & ' & $\begin{array}{l}8 \\
\dot{0} \\
\dot{0}\end{array}$ & . & ' & t \\
\hline & $\approx$ & $\begin{array}{l}\vec{\Xi} \\
\stackrel{\Xi}{\Xi} \\
\text { III }\end{array}$ & ' & ' & $\begin{array}{l}0 \\
\stackrel{?}{T} \\
T\end{array}$ & ' & ' & ' & 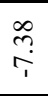 & ' & ' & $\frac{\sim}{?}$ & ' & ' & ' & $\frac{\stackrel{2}{+}}{i}$ & ' & ' & ' & ' & ' \\
\hline \multirow{4}{*}{$\begin{array}{l}0 \\
0 \\
0 \\
\frac{0}{0} \\
0 \\
0\end{array}$} & \& & $\begin{array}{l}\overrightarrow{0} \\
\stackrel{\Xi}{0} \\
ن\end{array}$ & $\frac{m}{6}$ & 官 & ஜு. & $\stackrel{r}{\infty}$ & $\frac{a}{6}$ & $\vec{\infty}$ & $\frac{n}{6}$ & 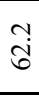 & $\stackrel{0}{8}$ & $\begin{array}{l}0 \\
\text { in }\end{array}$ & ' & $\begin{array}{l}0 \\
\text { ఠే }\end{array}$ & $\begin{array}{c}m \\
\infty \\
\infty\end{array}$ & తి & ì & ' & ' & ' & $\frac{1}{6}$ \\
\hline & $\approx$ & 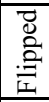 & ' & ' & $\begin{array}{l}\infty \\
\stackrel{\leftrightarrow}{n}\end{array}$ & $\begin{array}{l}\text { i } \\
\text { in }\end{array}$ & $\stackrel{\circ}{\vec{n}}$ & ' & ' & ' & $\begin{array}{l}\stackrel{i}{ } \\
\text { in }\end{array}$ & $\frac{n}{n}$ & ' & ֶֶ. & ' & $\hat{\mathrm{i}}$ & ' & ' & ' & ' & ' \\
\hline & 飞 & $\begin{array}{l}\overrightarrow{0} \\
\stackrel{0}{0} \\
\text { ¿ }\end{array}$ & $\begin{array}{l}0 \\
\dot{\sigma}\end{array}$ & $\hat{\sigma}$ & $\hat{8}$ & $\hat{\theta}$ & $\hat{v}$ & $\underset{0}{\infty}$ & $\begin{array}{l}1 \\
\infty \\
\infty\end{array}$ & $\begin{array}{l}\infty \\
\dot{b} \\
\dot{0}\end{array}$ & $\frac{7}{6}$ & İ & $\begin{array}{l}\infty \\
\infty \\
\infty \\
i\end{array}$ & $\begin{array}{l}+் \\
\ddot{8}\end{array}$ & ?ి & $\begin{array}{l}\infty \\
\dot{b} \\
ن\end{array}$ & ' & ' & ' & ' & ' \\
\hline & $\stackrel{\omega}{\sim}$ & 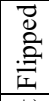 & ' & ' & ' & ' & ' & ' & ' & ' & ' & ' & 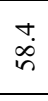 & ' & ' & ' & ' & ' & ' & ' & ' \\
\hline \multirow{4}{*}{$\begin{array}{l}\text { 鳬 } \\
\frac{2}{2}\end{array}$} & 是 & $\begin{array}{l}\overrightarrow{0} \\
\stackrel{\Xi}{0} \\
0\end{array}$ & ' & $\frac{+}{i}$ & ' & 움 & $\overrightarrow{\stackrel{m}{r}}$ & $\begin{array}{l}0 \\
0 \\
0 \\
0 \\
1\end{array}$ & $\frac{n}{\tilde{0}}$ & 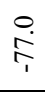 & ' & 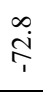 & ' & $\stackrel{n}{\stackrel{n}{T}}$ & ' & $\stackrel{n}{i}$ & 守 & $\begin{array}{l}0 \\
\stackrel{\infty}{\infty} \\
1\end{array}$ & సָ. & $\stackrel{n}{\stackrel{n}{T}}$ & $\hat{\sigma_{i}}$ \\
\hline & $\cong$ & $\begin{array}{l}\vec{\Xi} \\
\stackrel{\Xi}{\Xi} \\
\stackrel{\Xi}{I}\end{array}$ & $\stackrel{0}{\stackrel{0}{T}}$ & ' & 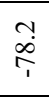 & $\begin{array}{l}\infty \\
\stackrel{+}{T}\end{array}$ & $\underset{\infty}{\stackrel{\infty}{+}}$ & $\begin{array}{l}\stackrel{0}{r} \\
\stackrel{i}{r}\end{array}$ & $\begin{array}{l}\text { ?ై } \\
\stackrel{1}{1}\end{array}$ & $\begin{array}{l}+ \\
\text { ț. } \\
\end{array}$ & 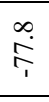 & $\underset{i}{\stackrel{r}{i}}$ & ' & $\begin{array}{l}\stackrel{\infty}{\infty} \\
\stackrel{\infty}{T}\end{array}$ & $\stackrel{?}{?}$ & 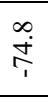 & ' & ' & ' & 1 & ' \\
\hline & \multirow{2}{*}{ 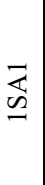 } & 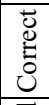 & $\begin{array}{l}0 \\
\ddot{\infty} \\
\dot{\infty}\end{array}$ & $\begin{array}{l}\infty \\
\dot{\infty} \\
\dot{\infty}\end{array}$ & $\begin{array}{l}\vec{\forall} \\
\ddot{\infty} \\
\infty \\
\dot{0}\end{array}$ & $\begin{array}{l}0 \\
\infty \\
\infty \\
\infty \\
1\end{array}$ & $\stackrel{\circ}{\grave{i}}$ & $\begin{array}{l}0 \\
\dot{+} \\
\dot{0} \\
1\end{array}$ & $\underset{\substack{\dot{\Phi}\\
}}{7}$ & $\underset{\dot{\infty}}{\stackrel{+}{+}}$ & $\begin{array}{l}0 \\
\infty \\
\stackrel{\infty}{T}\end{array}$ & $\begin{array}{l}\text { No } \\
\infty \\
\infty \\
1\end{array}$ & 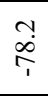 & $\begin{array}{l}n \\
\infty_{1}^{\infty}\end{array}$ & $\underset{\text { Tे }}{\stackrel{0}{T}}$ & $\hat{\infty}_{\infty}$ & $\stackrel{n}{i}$ & 芦 & 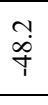 & $\frac{r}{i}$ & $\begin{array}{l}0 \\
\tilde{n} \\
\hat{n}\end{array}$ \\
\hline & & 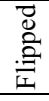 & ' & ' & ' & ' & ' & 1 & ' & ' & & ' & ' & ' & oे & ' & ' & ' & ' & ' & 1 \\
\hline & & & 2 & స్ & 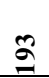 & $\tilde{\sigma}$ & 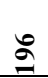 & $\widehat{\sigma}$ & $\stackrel{\infty}{\oplus}$ & $\overline{\mathrm{N}}$ & $\bar{a}$ & ڤ & I & $\mathscr{2}$ & $\stackrel{\infty}{I}$ & $\begin{array}{l}\mathbb{E}^{\mathbb{N}} \\
\Sigma\end{array}$ & $\stackrel{\infty}{\sigma}$ & $\partial$ & $\Phi$ & ః్సి & $\sum_{\Sigma}^{\tilde{\Xi}}$ \\
\hline
\end{tabular}




\section{References}

1. $\quad$ www.who.org (accessed 16. March 2011).

2. Weinberg, R. A., The biology of cancer. Garland Science: New York, 2007.

3. Cragg, G. M.; Grothaus, P. G.; Newman, D. J., Impact of Natural Products on Developing New Anti-Cancer Agents. Chem. Rev. 2009, 109, 3012-3043.

4. $\quad$ Dale, H., Paul Ehrlich. Brit. Med. J. 1954, 1, 659-663.

5. Felleskatalogen over farmasøytiske spesialpreparater registrert $i$ Norge: 2011. Felleskatalogen: 2011.

6. Silverman, R. B., The organic chemistry of drug design and drug action. second ed.; Elsevier: Amsterdam, 2004.

7. Ravelli, R. B. G.; Gigant, B.; Curmi, P. A.; Jourdain, I.; Lachkar, S.; Sobel, A.; Knossow, M., Insight into tubulin regulation from a complex with colchicine and a stathmin-like domain. Nature 2004, 428, 198-202.

8. Botta, M.; Forli, S.; Magnani, M.; Manetti, F., Tubulin-Binding Agents Synthetic: Structural and Mechanistic Insights. In Topics in Current Chemistry, Carlomagno, T., Ed. SpringerVerlag: Berline Heidelberg, 2009; Vol. 286, pp 279-328.

9. Cragg, G. M. L.; Newman, D. J.; Kingston, D. G. I., Anticancer agents from natural products. Taylor \& Francis: Boca Raton, Fla., 2005.

10. Teicher, B. A.; Fojo, T., The Role of Microtubules in Cell Biology, Neurobiology, and Oncology. Humana Press: Totowa, NJ, 2008.

11. Giavazzi, R.; Bonezzi, K.; Taraboletti, G., Microtubule targeting agents and the tumor vasculature. In The Role of Microtubules in Cell Biology, Neurobiology, and Oncology, Fojo, T., Ed. Humana Press: Totowa, NJ, 2008; pp 519-530.

12. Li, J.; Yuan, J., Caspases in apoptosis and beyond. Oncogene 2008, 27, 6194-6206.

13. Cohen, G. M., Caspases: the executioners of apoptosis. Biochem. J. 1997, 326, 1-16.

14. Donepudi, M.; Grütter, M. G., Structure and zymogen activation of caspases. Biophys. Chem. 2002, 101-102, 145-153.

15. Boatright, K. M.; Salvesen, G. S., Mechanisms of caspase activation. Curr. Opin. Cell Biol. 2003, 15, 725-731.

16. Kumar, S., Caspase function in programmed cell death. Cell Death Differ. 2007, 14, 32-43.

17. Chowdhury, I.; Tharakan, B.; Bhat, G. K., Caspases - An update. Comp. Biochem. Phys. B 2008, 151, 10-27.

18. Chai, J.; Wu, Q.; Shiozaki, E.; Srinivasula, S. M.; Alnemri, E. S.; Shi, Y., Crystal Structure of a Procaspase-7 Zymogen: Mechanisms of Activation and Substrate Binding. Cell 2001, 107, 399-407.

19. Häcker, H.-G.; Sisay, M. T.; Gütschow, M., Allosteric modulation of caspases. Pharmacol. Therapeut. 2011, 132, 180-195.

20. Roy, S.; Bayly, C. I.; Gareau, Y.; Houtzager, V. M.; Kargman, S.; Keen, S. L. C.; Rowland, K.; Seiden, I. M.; Thornberry, N. A.; Nicholson, D. W., Maintenance of caspase-3 proenzyme dormancy by an intrinsic "safety catch" regulatory tripeptide. Proc. Natl. Acad. Sci. U. S. A. 2001, 98, 6132-6137.

21. Perry, D. K.; Smyth, M. J.; Stennicke, H. R.; Salvesen, G. S.; Duriez, P.; Poirier, G. G.; Hannun, Y. A., Zinc Is a Potent Inhibitor of the Apoptotic Protease, Caspase-3. A NOVEL TARGET FOR ZINC IN THE INHIBITION OF APOPTOSIS. J. Biol. Chem. 1997, 272, 18530-18533.

22. Chimienti, F.; Seve, M.; Richard, S.; Mathieu, J.; Favier, A., Role of cellular zinc in programmed cell death: temporal relationship between zinc depletion, activation of caspases, and cleavage of Sp family transcription factors. Biochem. Pharmacol. 2001, 62, 
51-62.

23. Truong-Tran, A. Q.; Carter, J.; Ruffin, R. E.; Zalewski, P. D., The role of zinc in caspase activation and apoptotic cell death. BioMetals 2001, 14, 315-330.

24. Deveraux, Q. L.; Takahashi, R.; Salvesen, G. S.; Reed, J. C., X-linked IAP is a direct inhibitor of cell-death proteases. Nature 1997, 388, 300-304.

25. Holcik, M.; Korneluk, R. G., Functional Characterization of the X-Linked Inhibitor of Apoptosis (XIAP) Internal Ribosome Entry Site Element: Role of La Autoantigen in XIAP Translation. Mol. Cell. Biol. 2000, 20, 4648-4657.

26. Han, B. H.; Xu, D.; Choi, J.; Han, Y.; Xanthoudakis, S.; Roy, S.; Tam, J.; Vaillancourt, J.; Colucci, J.; Siman, R.; Giroux, A.; Robertson, G. S.; Zamboni, R.; Nicholson, D. W.; Holtzman, D. M., Selective, Reversible Caspase-3 Inhibitor Is Neuroprotective and Reveals Distinct Pathways of Cell Death after Neonatal Hypoxic-ischemic Brain Injury. J. Biol. Chem. 2002, 277, 30128-30136.

27. Kravchenko, D. V.; Kysil, V. M.; Tkachenko, S. E.; Maliarchouk, S.; Okun, I. M.; Ivachtchenko, A. V., Pyrrolo[3,4-c]quinoline-1,3-diones as potent caspase-3 inhibitors. Synthesis and SAR of 2-substituted 4-methyl-8-(morpholine-4-sulfonyl)-pyrrolo[3,4c] quinoline-1,3-diones. Eur. J. Med. Chem. 2005, 40, 1377-1383.

28. Lee, D.; Long, S. A.; Murray, J. H.; Adams, J. L.; Nuttall, M. E.; Nadeau, D. P.; Kikly, K.; Winkler, J. D.; Sung, C.-M.; Ryan, M. D.; Levy, M. A.; Keller, P. M.; DeWolf, W. E., Potent and Selective Nonpeptide Inhibitors of Caspases 3 and 7. J. Med. Chem. 2001, 44, 20152026.

29. Han, Y.; Giroux, A.; Colucci, J.; Bayly, C. I.; McKay, D. J.; Roy, S.; Xanthoudakis, S.; Vaillancourt, J.; Rasper, D. M.; Tam, J.; Tawa, P.; Nicholson, D. W.; Zamboni, R. J., Novel pyrazinone mono-amides as potent and reversible caspase-3 inhibitors. Bioorg. Med. Chem. Lett. 2005, 15, 1173-1180.

30. Ng, S. L.; Yang, P.-Y.; Chen, K. Y. T.; Srinivasan, R.; Yao, S. Q., "Click" synthesis of smallmolecule inhibitors targeting caspases. Org. Biomol. Chem. 2008, 6, 844-847.

31. Li, Y.; Cohen, R., Caspase Inhibitors and Myocardial Apoptosis. International Anesthesiology Clinics 2005, 43, 77-89.

32. Nakagawara, A.; Nakamura, Y.; Ikeda, H.; Hiwasa, T.; Kuida, K.; Su, M. S.-S.; Zhao, H.; Cnaan, A.; Sakiyama, S., High Levels of Expression and Nuclear Localization of Interleukin-1 $\beta$ Converting Enzyme (ICE) and CPP32 in Favorable Human Neuroblastomas. Cancer Res. 1997, 57, 4578-4584.

33. Izban, K. F.; Wrone-Smith, T.; Hsi, E. D.; Schnitzer, B.; Quevedo, M. E.; Alkan, S., Characterization of the Interleukin-1 $\beta$-Converting Enzyme/Ced-3-Family Protease, Caspase3/CPP32, in Hodgkin's Disease: Lack of Caspase-3 Expression in Nodular Lymphocyte Predominance Hodgkin's Disease. Am. J. Pathol. 1999, 154, 1439-1447.

34. Estrov, Z.; Thall, P. F.; Talpaz, M.; Estey, E. H.; Kantarjian, H. M.; Andreeff, M.; Harris, D.; Van, Q.; Walterscheid, M.; Kornblau, S. M., Caspase 2 and Caspase 3 Protein Levels as Predictors of Survival in Acute Myelogenous Leukemia. Blood 1998, 92, 3090-3097.

35. Fink, D.; Schlagbauer-Wadl, H.; Selzer, E.; Lucas, T.; Wolff, K.; Pehamberger, H.; Eichler, H.-G.; Jansen, B., Elevated procaspase levels in human melanoma. Melanoma Res. 2001, 4, 385-393.

36. Persad, R.; Liu, C.; Wu, T.-T.; Houlihan, P. S.; Hamilton, S. R.; Diehl, A. M.; Rashid, A., Overexpression of caspase-3 in hepatocellular carcinomas. Mod. Pathol. 2004, 17, 861-867.

37. Svingen, P. A.; Loegering, D.; Rodriquez, J.; Meng, X. W.; Mesner, P. W.; Holbeck, S.; Monks, A.; Krajewski, S.; Scudiero, D. A.; Sausville, E. A.; Reed, J. C.; Lazebnik, Y. A.; Kaufmann, S. H., Components of the Cell Death Machine and Drug Sensitivity of the National Cancer Institute Cell Line Panel. Clin. Cancer Res. 2004, 10, 6807-6820.

38. Putt, K. S.; Chen, G. W.; Pearson, J. M.; Sandhorst, J. S.; Hoagland, M. S.; Kwon, J.-T.; Hwang, S.-K.; Jin, H.; Churchwell, M. I.; Cho, M.-H.; Doerge, D. R.; Helferich, W. G.; 
Hergenrother, P. J., Small-molecule activation of procaspase-3 to caspase-3 as a personalized anticancer strategy. Nat. Chem. Biol. 2006, 2, 543-550.

39. Denault, J.-B.; Drag, M.; Salvesen, G. S.; Alves, J.; Heidt, A. B.; Deveraux, Q.; Harris, J. L., Small molecules not direct activators of caspases. Nat. Chem. Biol. 2007, 3, 519-519.

40. Hergenrother, P. J.; Putt, K. S.; Sandhorst, J. S., Reply to 'Small molecules not direct activators of caspases'. Nat. Chem. Biol. 2007, 3, 520.

41. Kovacic, P., Does Structural Commonality of Metal Complex Formation by PAC-1 (anticancer), DHBNH (anti-HIV), AHL (autoinducer), and UCS1025A (anticancer) Denote Mechanistic Similarity? Signal Transduction and Medical Aspects. J. Recept. Signal Transduction 2008, 28, 141-152.

42. NoblIa, P.; Vieites, M.; Parajón-Costa, B. S.; Baran, E. J.; Cerecetto, H.; Draper, P.; González, M.; Piro, O. E.; Castellano, E. E.; Azqueta, A.; López de Ceráin, A.; Monge-Vega, A.; Gambino, D., Vanadium(V) complexes with salicylaldehyde semicarbazone derivatives bearing in vitro anti-tumor activity toward kidney tumor cells (TK-10): crystal structure of [VVO2(5-bromosalicylaldehyde semicarbazone)]. J. Inorg. Biochem. 2005, 99, 443-451.

43. Charkoudian, L. K.; Pham, D. M.; Franz, K. J., A Pro-Chelator Triggered by Hydrogen Peroxide Inhibits Iron-Promoted Hydroxyl Radical Formation. J. Am. Chem. Soc. 2006, 128, 12424-12425.

44. Treves, S.; Trentini, P. L.; Ascanelli, M.; Bucci, G.; Di Virgilio, F., Apoptosis Is Dependent on Intracellular Zinc and Independent of Intracellular Calcium in Lymphocytes. Exp. Cell Res. 1994, 211, 339-343.

45. Hyun, H. J.; Sohn, J. H.; Ha, D. W.; Ahn, Y. H.; Koh, J.-Y.; Yoon, Y. H., Depletion of Intracellular Zinc and Copper with TPEN Results in Apoptosis of Cultured Human Retinal Pigment Epithelial Cells. Invest. Ophtalmol. Vis. Sci. 2001, 42, 460-465.

46. Peterson, Q. P.; Goode, D. R.; West, D. C.; Ramsey, K. N.; Lee, J.; Hergenrother, P. J., PAC1 Activates Procaspase-3 in Vitro through Relief of Zinc-Mediated Inhibition. J. Mol. Bio. 2009, 388, 144-158.

47. Peterson, Q. P.; Hsu, D. C.; Goode, D. R.; Novotny, C. J.; Totten, R. K.; Hergenrother, P. J., Procaspase-3 activation as an anti-cancer strategy: structure-activity relationship of procaspase-activating compound 1 (PAC-1) and its cellular co-localization with caspase-3. $J$. Med. Chem. 2009, 52, 5721-5731.

48. Ren, L.; Bi, K.; Gong, P.; Cheng, W.; Song, Z.; Fang, L.; Chen, X., Characterization of the in vivo and in vitro metabolic profile of PAC-1 using liquid chromatography-mass spectrometry. J. Chromatogr. B 2008, 876, 47-53.

49. Fang, L.-N.; Chen, X.-H.; Song, Z.; Wang, G.; Zhao, X.; Ren, L.; Gong, P.; Bi, K.-S., Development of a high performance liquid chromatography method for quantification of PAC-1 in rat plasma. J. Pharmaceut. Biomed. 2009, 49, 447-450.

50. Song, Z.; Chen, X.-H.; Zhang, D.; Gong, P.; Bi, K.-S., Isolation and structure elucidation of degradation products in the potential anticancer drug PAC-1. J. Pharmaceut. Biomed. 2010, 51,965-968.

51. Lucas, P.; Schmit, J.; Peterson, Q.; West, D.; Hsu, D.; Novotny, C.; Dirikolu, L.; Churchwell, M.; Doerge, D.; Garrett, L.; Hergenrother, P.; Fan, T., Pharmacokinetics and derivation of an anticancer dosing regimen for PAC-1, a preferential small molecule activator of procaspase3, in healthy dogs. Invest. New Drugs 2010, 1-11.

52. Wolan, D. W.; Zorn, J. A.; Gray, D. C.; Wells, J. A., Small-Molecule Activators of a Proenzyme. Science 2009, 326, 853-858.

53. Schipper, J. L.; MacKenzie, S. H.; Sharma, A.; Clark, A. C., A bifunctional allosteric site in the dimer interface of procaspase-3. Biophys. Chem. 2011, 159, 100-109.

54. Young, S. L.; Chaplin, D. J., Combretastatin A4 phosphate: background and current clinical status. Expert Opin. Inv. Drug. 2004, 13, 1171-1182.

55. Pasquier, E.; Andre, N.; Braguer, D., Targeting Microtubules to Inhibit Angiogenesis and 
Disrupt Tumour Vasculature:Implications for Cancer Treatment. Curr. Cancer Drug Targets 2007, 7, 566-581.

56. Kanthou, C.; Tozer, G. M., Microtubule depolymerizing vascular disrupting agents: novel therapeutic agents for oncology and other pathologies. Int. J. Exp. Pathol. 2009, 90, 284294.

57. Shan, Y. S.; Zhang, J.; Liu, Z.; Wang, M.; Dong, Y., Developments of Combretastatin A-4 Derivatives as Anticancer Agents. Curr. Med. Chem. 2011, 18, 523-538.

58. Cirla, A.; Mann, J., Combretastatins: from natural products to drug discovery. Nat. Prod. Rep. 2003, 20, 558-564.

59. Tanpure, R. P.; Nguyen, B. L.; Strecker, T. E.; Aguirre, S.; Sharma, S.; Chaplin, D. J.; Siim, B. G.; Hamel, E.; Lippert, J. W.; Pettit, G. R.; Trawick, M. L.; Pinney, K. G., Regioselective Synthesis of Water-Soluble Monophosphate Derivatives of Combretastatin A-1. J. Nat. Prod. 2011, 74, 1568-1574.

60. Pettit, G. R.; Lippert, J. W., Antineoplastic agents 429. Syntheses of the combretastatin A-1 and combretastatin B-1 prodrugs. Anti-cancer Drug Des. 2000, 15, 203-216.

61. Siemann, D. W.; Chaplin, D. J.; Walicke, P. A., A review and update of the current status of the vasculature-disabling agent combretastatin-A4 phosphate (CA4P). Expert Opin. Inv. Drug. 2009, 18, 189-197.

62. Pettit, G. R.; Cragg, G. M.; Herald, D. L.; Schmidt, J. M.; Lohavanijaya, P., Isolation and structure of combretastatin. Can. J. Chem. 1982, 60, 1374-1376.

63. Hamel, E.; Lin, C. M., Interactions of combretastatin, a new plant-derived antimitotic agent, with tubulin. Biochem. Pharmacol. 1983, 32, 3864-3867.

64. Annapurna, G. S.; Deshpande, V. H., Synthesis of $( \pm)$ Combretastatin. Synth. Commun. 1983, 13, 1075-1082.

65. Pettit, G. R.; Singh, S. B.; Cragg, G. M., Antineoplastic agents. 113. Synthesis of natural (-)combretastatin. J. Org. Chem. 1985, 50, 3404-3406.

66. Pettit, G. R.; Singh, S. B., Isolation, structure, and synthesis of combretastatin A-2, A-3, and B-2. Can. J. Chem. 1987, 65, 2390-2396.

67. Pettit, G. R.; Singh, S. B.; Niven, M. L.; Hamel, E.; Schmidt, J. M., Isolation, Structure, and Synthesis of Combretastatins A-1 and B-1, Potent New Inhibitors of Microtubule Assembly, Derived from Combretum caffrum. J. Nat. Prod. 1987, 50, 119-131.

68. Lin, C. M.; Singh, S. B.; Chu, P. S.; Dempcy, R. O.; Schmidt, J. M.; Pettit, G. R.; Hamel, E., Interactions of tubulin with potent natural and synthetic analogs of the antimitotic agent combretastatin: a structure-activity study. Mol. Pharmacol. 1988, 34, 200-208.

69. Pettit, G. R.; Singh, S. B.; Niven, M. L., Antineoplastic agents. 160. Isolation and structure of combretastatin D-1: a cell growth inhibitory macrocyclic lactone from Combretum caffrum. J. Am. Chem. Soc. 1988, 110, 8539-8540.

70. Pettit, G. R.; Singh, S. B.; Schmidt, J. M.; Nixen, M. L.; Hamel, E.; Lin, C. M., Isolation, Structure, Synthesis, and Antimitotic Properties of Combretastatins B-3 and B-4 from Combretum caffrum. J. Nat. Prod. 1988, 51, 517-527.

71. Pettit, G. R.; Singh, S. B.; Hamel, E.; Lin, C. M.; Alberts, D. S.; Garcia-Kendal, D., Isolation and structure of the strong cell growth and tubulin inhibitor combretastatin A-4. Experientia 1989, 45, 209-211.

72. Singh, S. B.; Pettit, G. R., Antineoplastic agents. 166. Isolation, structure, and synthesis of combretastatin C-1. J. Org. Chem. 1989, 54, 4105-4114.

73. Singh, S. B.; Pettit, G. R., Antineoplastic agents. 206. Structure of the cytostatic macrocyclic lactone combretastatin D-2. J. Org. Chem. 1990, 55, 2797-2800.

74. Pettit, G. R.; Singh, S. B.; Boyd, M. R.; Hamel, E.; Pettit, R. K.; Schmidt, J. M.; Hogan, F., Antineoplastic Agents. 291. Isolation and Synthesis of Combretastatins A-4, A-5, and A-6. J. Med. Chem. 1995, 38, 1666-1672.

75. Pettit, G. R.; Singh, S. B.; Boyd, M. R.; Hamel, E.; Pettit, R. K.; Schmidt, J. M.; Hogan, F., 
Antineoplastic Agents. 291. Isolation and Synthesis of Combretastatins A-4, A-5, and A-6. [Erratum to document cited in CA122:290568]. J. Med. Chem. 1995, 38, 2994-2994.

76. Orsini, F.; Pelizzoni, F.; Bellini, B.; Miglierini, G., Synthesis of biologically active polyphenolic glycosides (combretastatin and resveratrol series). Carbohydr. Res. 1997, 301, 95-109.

77. Pettit, G. R.; Lippert, J. W., Antineoplastic agents 429. Syntheses of the combretastatin A-1 and combretastatin B-1 prodrugs. Anti-cancer Drug Des. 2000, 15, 203-216.

78. Brown, R. T.; Murrell, V. L.; McMordie, A.; Sriram, M.; Pinney, K. G.; Sharma, S.; Chaplin, D. J., Carbon-14 radiosynthesis of combretastatin A-1 (CA1) and its corresponding phosphate prodrug (CA1P). J. Labelled Compd. Rad. 2009, 52, 567-570.

79. Shirali, A.; Sriram, M.; Hall, J. J.; Nguyen, B. L.; Guddneppanavar, R.; Hadimani, M. B.; Ackley, J. F.; Siles, R.; Jelinek, C. J.; Arthasery, P.; Brown, R. C.; Murrell, V. L.; McMordie, A.; Sharma, S.; Chaplin, D. J.; Pinney, K. G., Development of Synthetic Methodology Suitable for the Radiosynthesis of Combretastatin A-1 (CA1) and Its Corresponding Prodrug CA1P. J. Nat. Prod. 2009, 72, 414-421.

80. Bui, V. P.; Hudlický, T.; Hansen, T. V.; Stenstrøm, Y., Direct biooxidation of arenes to corresponding catechols with E. coli JM109 (pDTG602). Application to synthesis of combretastatins A-1 and B-1. Tetrahedron Lett. 2002, 43, 2839-2841.

81. Hansen, T. V.; Skattebøl, L., One-pot synthesis of substituted catechols from the corresponding phenols. Tetrahedron Lett. 2005, 46, 3357-3358.

82. Odlo, K.; Klaveness, J.; Rongved, P.; Hansen, T. V., Synthesis of combretastatins A-1 and B1. Tetrahedron Lett. 2006, 47, 1101-1103.

83. Kirwan, I. G.; Loadman, P. M.; Swaine, D. J.; Anthoney, D. A.; Pettit, G. R.; Lippert, J. W.; Shnyder, S. D.; Cooper, P. A.; Bibby, M. C., Comparative Preclinical Pharmacokinetic and Metabolic Studies of the Combretastatin Prodrugs Combretastatin A4 Phosphate and A1 Phosphate. Clin. Cancer Res. 2004, 10, 1446-1453.

84. Folkes, L. K.; Christlieb, M.; Madej, E.; Stratford, M. R. L.; Wardman, P., Oxidative Metabolism of Combretastatin A-1 Produces Quinone Intermediates with the Potential To Bind to Nucleophiles and To Enhance Oxidative Stress via Free Radicals. Chem. Res. Tox. 2007, 20, 1885-1894.

85. Pettit, G. R.; Thornhill, A. J.; Moser, B. R.; Hogan, F., Antineoplastic Agents. 552. Oxidation of Combretastatin A-1: Trapping the o-Quinone Intermediate Considered the Metabolic Product of the Corresponding Phosphate Prodrug. J. Nat. Prod. 2008, 71, 1561-1563.

86. Rice, L.; Pampo, C.; Lepler, S.; Rojiani, A. M.; Siemann, D. W., Support of a free radical mechanism for enhanced antitumor efficacy of the microtubule disruptor OXi4503. Microvasc. Res. 2011, 81, 44-51.

87. Salmon, H. W.; Mladinich, C.; Siemann, D. W., Evaluations of vascular disrupting agents CA4P and OXi4503 in renal cell carcinoma (Caki-1) using a silicon based microvascular casting technique. Eur. J. Cancer 2006, 42, 3073-3078.

88. Salmon, H. W.; Siemann, D. W., Effect of the Second-Generation Vascular Disrupting Agent OXi4503 on Tumor Vascularity. Clin. Cancer Res. 2006, 12, 4090-4094.

89. Tozer, G. M.; Kanthou, C.; Baguley, B. C., Disrupting tumour blood vessels. Nat Rev Cancer 2005, 5, 423-435.

90. Pettit, G. R.; Grealish, M. P.; Herald, D. L.; Boyd, M. R.; Hamel, E.; Pettit, R. K., Antineoplastic Agents. 443. Synthesis of the Cancer Cell Growth Inhibitor Hydroxyphenstatin and Its Sodium Diphosphate Prodrug. J. Med. Chem. 2000, 43, 27312737.

91. Pettit, G. R.; Lippert, J. W.; Herald, D. L.; Hamel, E.; Pettit, R. K., Antineoplastic Agents 440. Asymmetric Synthesis and Evaluation of the Combretastatin A-1 SAR Probes $(1 S, 2 S)$ and $\quad(1 R, 2 R)-1,2-D i h y d r o x y-\quad 1-\left(2^{\prime}, 3^{\prime}\right.$-dihydroxy-4'-methoxyphenyl)-2-(3“",4“, $5^{\prime \prime}$ trimethoxyphenyl)-ethane. J. Nat. Prod. 2000, 63, 969-974. 
92. Hua, J.; Sheng, Y.; Pinney, K. G.; Garner, C. M.; Kane, R. R.; Prezioso, J. A.; Pettit, G. R.; Chaplin, D. J.; Edvardsen, K., Oxi4503, a novel vascular targeting agent: effects on blood flow and antitumor activity in comparison to combretastatin A-4 phosphate. Anticancer Res. 2003, 23, 1433-1440.

93. Singh, R.; Kaur, H., Advances in Synthetic Approaches for the Preparation of Combretastatin-Based Anti-Cancer Agents. Synthesis 2009, 2471-2491.

94. Srivastava, V.; Negi, A. S.; Kumar, J. K.; Gupta, M. M.; Khanuja, S. P. S., Plant-based anticancer molecules: A chemical and biological profile of some important leads. Bioorg. Med. Chem. 2005, 13, 5892-5908.

95. Chaudhary, A.; Pandeya, S. N.; Kumar, P.; Sharma, P. P.; Gupta, S.; Soni, N.; Verma, K. K.; Bhardwaj, G., Combretastatin A-4 Analogs as Anticancer Agents. Mini-Rev. Med. Chem. 2007, 7, 1186-1205.

96. Tron, G. C.; Pirali, T.; Sorba, G.; Pagliai, F.; Busacca, S.; Genazzani, A. A., Medicinal Chemistry of Combretastatin A4: Present and Future Directions. J. Med. Chem. 2006, 49, 3033-3044.

97. Pinney, K. G.; Jelinek, C.; Edvardsen, K.; Chaplin, D. J.; Pettit, G. R., The Discovery and Development of the Combrretastatins. In Anticancer agents from natural products, Cragg, G. M.; Grothaus, P. G.; Newman, D. J., Eds. Taylor \& Francis: Boca Raton, Fla., 2005; pp 2346.

98. Pettit, G. R.; Thornhill, A.; Melody, N.; Knight, J. C., Antineoplastic Agents. 578. Synthesis of Stilstatins 1 and 2 and Their Water-Soluble Prodrugs. J. Nat. Prod. 2009, 72, 380-388.

99. Cushman, M.; Nagarathnam, D.; Gopal, D.; Chakraborti, A. K.; Lin, C. M.; Hamel, E., Synthesis and evaluation of stilbene and dihydrostilbene derivatives as potential anticancer agents that inhibit tubulin polymerization. J. Med. Chem. 1991, 34, 2579-2588.

100. Tron, G. C.; Pagliai, F.; Del Grosso, E.; Genazzani, A. A.; Sorba, G., Synthesis and Cytotoxic Evaluation of Combretafurazans. J. Med. Chem. 2005, 48, 3260-3268.

101. Cushman, M.; Nagarathnam, D.; Gopal, D.; He, H. M.; Lin, C. M.; Hamel, E., Synthesis and evaluation of analogs of (Z)-1-(4-methoxyphenyl)-2-(3,4,5-trimethoxyphenyl)ethene as potential cytotoxic and antimitotic agents. J. Med. Chem. 1992, 35, 2293-2306.

102. Wang, L.; Woods, K. W.; Li, Q.; Barr, K. J.; McCroskey, R. W.; Hannick, S. M.; Gherke, L.; Credo, R. B.; Hui, Y.-H.; Marsh, K.; Warner, R.; Lee, J. Y.; Zielinski-Mozng, N.; Frost, D.; Rosenberg, S. H.; Sham, H. L., Potent, Orally Active Heterocycle-Based Combretastatin A-4 Analogues: Synthesis, Structure-Activity Relationship, Pharmacokinetics, and In Vivo Antitumor Activity Evaluation. J. Med. Chem. 2002, 45, 1697-1711.

103. Pettit, G. R.; Lippert, J. W.; Boyd, M. R.; Verdier-Pinard, P.; Hamel, E., Antineoplastic agents 442. Synthesis and biological activities of dioxostatin. Anti-cancer Drug Des. 2000, $15,361-371$.

104. Nam, N.-H.; Kim, Y.; You, Y.-J.; Hong, D.-H.; Kim, H.-M.; Ann, B.-Z., Synthesis, cytotoxicity and antitumor activity of 2,3-Diarylcy-clopent-2-ene-1-ones. Arch. Pharm. Res, 2002, 25, 600-607.

105. Siles, R.; Ackley, J. F.; Hadimani, M. B.; Hall, J. J.; Mugabe, B. E.; Guddneppanavar, R.; Monk, K. A.; Chapuis, J.-C.; Pettit, G. R.; Chaplin, D. J.; Edvardsen, K.; Trawick, M. L.; Garner, C. M.; Pinney, K. G., Combretastatin Dinitrogen-Substituted Stilbene Analogues as Tubulin-Binding and Vascular-Disrupting Agents. J. Nat. Prod. 2008, 71, 313-320.

106. Monk, K. A.; Siles, R.; Hadimani, M. B.; Mugabe, B. E.; Ackley, J. F.; Studerus, S. W.; Edvardsen, K.; Trawick, M. L.; Garner, C. M.; Rhodes, M. R.; Pettit, G. R.; Pinney, K. G., Design, synthesis, and biological evaluation of combretastatin nitrogen-containing derivatives as inhibitors of tubulin assembly and vascular disrupting agents. Bioorg. Med. Chem. 2006, 14, 3231-3244.

107. Lawrence, N. J.; Hepworth, L. A.; Rennison, D.; McGown, A. T.; Hadfield, J. A., Synthesis and anticancer activity of fluorinated analogues of combretastatin A-4. J. Fluorine Chem. 
2003, 123, 101-108.

108. Tanpure, R. P.; Strecker, T. E.; Chaplin, D. J.; Siim, B. G.; Trawick, M. L.; Pinney, K. G., Regio- and Stereospecific Synthesis of Mono- $\beta$-d-Glucuronic Acid Derivatives of Combretastatin A-1. J. Nat. Prod. 2010, 73, 1093-1101.

109. Harrowven, D. C.; Guy, I. L.; Howell, M.; Packham, G., The Synthesis of a Combretastatin A-4 Based Library and Discovery of New Cooperative ortho-Effects in Wittig Reactions Leading to (Z)-Stilbenes. Synlett 2006, 2977-2980.

110. Sriram, M.; Hall, J. J.; Grohmann, N. C.; Strecker, T. E.; Wootton, T.; Franken, A.; Trawick, M. L.; Pinney, K. G., Design, synthesis and biological evaluation of dihydronaphthalene and benzosuberene analogs of the combretastatins as inhibitors of tubulin polymerization in cancer chemotherapy. Bioorg. Med. Chem. 2008, 16, 8161-8171.

111. Carr, M.; Greene, L. M.; Knox, A. J. S.; Lloyd, D. G.; Zisterer, D. M.; Meegan, M. J., Lead identification of conformationally restricted $\beta$-lactam type combretastatin analogues: Synthesis, antiproliferative activity and tubulin targeting effects. Eur. J. Med. Chem. 2010, $45,5752-5766$.

112. Duan, J.-X.; Cai, X.; Meng, F.; Lan, L.; Hart, C.; Matteucci, M., Potent Antitubulin Tumor Cell Cytotoxins Based on 3-Aroyl Indazoles. J. Med. Chem. 2007, 50, 1001-1006.

113. Odlo, K. Synthesis and Biological Evaluation of 1,2,3-Triazole Analogues of Combretastatins A-4 and A-1. University of Oslo, Oslo, 2010.

114. Rang, H. P.; Dale, M. M.; Ritter, J. M.; Moore, P. K., Pharmacology. Fifth ed.; Churchill Livingstone: Edinburgh, 2003.

115. Seegers, J. C.; Aveling, M. L.; Van Aswegen, C. H.; Cross, M.; Koch, F.; Joubert, W. S., The cytotoxic effects of estradiol-17 $\beta$, catecholestradiols and methoxyestradiols on dividing MCF-7 and HeLa cells. J. Steroid Biochem. 1989, 32, 797-809.

116. Fotsis, T.; Zhang, Y.; Pepper, M. S.; Adlercreutz, H.; Montesano, R.; Nawroth, P. P.; Schweigerer, L., The endogenous oestrogen metabolite 2-methoxyoestradiol inhibits angiogenesis and suppresses tumour growth. Nature 1994, 368, 237-239.

117. Klauber, N.; Parangi, S.; Flynn, E.; Hamel, E.; D'Amato, R. J., Inhibition of Angiogenesis and Breast Cancer in Mice by the Microtubule Inhibitors 2-Methoxyestradiol and Taxol. Cancer Res. 1997, 57, 81-86.

118. Mooberry, S. L., Mechanism of action of 2-methoxyestradiol: new developments. Drug Resist. Update. 2003, 6, 355-361.

119. Mueck, A. O.; Seeger, H., 2-Methoxyestradiol--Biology and mechanism of action. Steroids 2010, 75, 625-631.

120. LaVallee, T. M.; Burke, P. A.; Swartz, G. M.; Hamel, E.; Agoston, G. E.; Shah, J.; Suwandi, L.; Hanson, A. D.; Fogler, W. E.; Sidor, C. F.; Treston, A. M., Significant antitumor activity in vivo following treatment with the microtubule agent ENMD-1198. Mol. Cancer Ther. 2008, 7, 1472-1482.

121. Fishman, J., Synthesis of 2-Methoxyestrogens. J. Am. Chem. Soc. 1958, 80, 1213-1216.

122. Paaren, H. E.; Duff, S. R. Synthesis of 2-hydroxyestradiol derivatives. USP 6448419, 2002.

123. Kiuru, P. S.; Wähälä, K., Short synthesis of 2-methoxyestradiol and 2-hydroxyestradiol. Steroids 2003, 68, 373-375.

124. Rao, P. N.; Burdett, J. E., Jr., A novel, two-step synthesis of 2-methoxyestradiol. Synthesis 1977, 168-169.

125. Numazawa, M.; Ogura, Y., Efficient synthesis of 2-methoxy- and 4-methoxy-estrogens. $J$. Chem. Soc. Chem. Comm. 1983, 533-534.

126. Chen, S.-h.; Luo, G.-r.; Wu, X.-s.; Chen, M.; Zhao, H.-m., A new synthetic route to 2- and 4methoxyestradiols by nucleophilic substitution. Steroids 1986, 47, 63-81.

127. Xin, M.; You, Q.; Xiang, H., An efficient, practical synthesis of 2-methoxyestradiol. Steroids 2010, 75, 53-56.

128. He, H.-M.; Cushman, M., A versatile synthesis of 2-methoxyestradiol, an endogenous 
metabolite of estradiol which inhibits tubulin polymerization by binding to the colchicine binding site. Bioorg. Med. Chem. Lett. 1994, 4, 1725-1728.

129. Wang, Z.; Cushman, M., An Optimized Synthesis of 2-Methoxyestradiol, A Naturally Occurring Human Metabolite with Anticancer Activity. Synth. Commun. 1998, 28, 44314437.

130. Leese, M. P.; Hejaz, H. A. M.; Mahon, M. F.; Newman, S. P.; Purohit, A.; Reed, M. J.; Potter, B. V. L., A-Ring-Substituted Estrogen-3-O-sulfamates: Potent Multitargeted Anticancer Agents. J. Med. Chem. 2005, 48, 5243-5256.

131. Pert, D. J.; Ridley, D. D., Formylation of estrogens. Aust. J. Chem. 1989, 42, 405-419.

132. Lovely, C. J.; Gilbert, N. E.; Liberto, M. M.; Sharp, D. W.; Lin, Y. C.; Brueggemeier, R. W., 2-(Hydroxyalkyl)estradiols: Synthesis and Biological Evaluation. J. Med. Chem. 1996, 39, 1917-1923.

133. Le Bras, J.; Rager, M. N.; Besace, Y.; Amouri, H.; Vaissermann, J., Activation and Regioselective Ortho-Functionalization of the A-Ring of $\beta$-Estradiol Promoted by "Cp* $\mathrm{Ir}^{\prime}$ : An Efficient Organometallic Procedure for the Synthesis of 2-Methoxyestradiol. Organometallics 1997, 16, 1765-1771.

134. Rao, P. N.; Cessac, J. W.; Tinley, T. L.; Mooberry, S. L., Synthesis and antimitotic activity of novel 2-methoxyestradiol analogs. Steroids 2002, 67, 1079-1089.

135. Hou, Y.; Meyers, C. Y.; Akomeah, M., A Short, Economical Synthesis of 2Methoxyestradiol, an Anticancer Agent in Clinical Trials. J. Org. Chem. 2009, 74, 63626364.

136. Stoelwinder, J.; Moers, N. E. C. Process for the preparation 2-substituted derivatives of estrone and estradiol. WO2006013196A1, 2006.

137. Kuntz, I. D.; Blaney, J. M.; Oatley, S. J.; Langridge, R.; Ferrin, T. E., A geometric approach to macromolecule-ligand interactions. J. Mol. Bio. 1982, 161, 269-288.

138. Moitessier, N.; Englebienne, P.; Lee, D.; Lawandi, J.; Corbeil, C. R., Towards the development of universal, fast and highly accurate docking/scoring methods: a long way to go. Br. J. Pharmacol. 2008, 153, S7-S26.

139. Gohlke, H.; Klebe, G., Approaches to the Description and Prediction of the Binding Affinity of Small-Molecule Ligands to Macromolecular Receptors. Angew. Chem. Int. Ed. 2002, 41, 2644-2676.

140. Kitchen, D. B.; Decornez, H.; Furr, J. R.; Bajorath, J., Docking and scoring in virtual screening for drug discovery: methods and applications. Nat. Rev. Drug Discov. 2004, 3, 935-949.

141. Huang, S.-Y.; Grinter, S. Z.; Zou, X., Scoring functions and their evaluation methods for protein-ligand docking: recent advances and future directions. Phys. Chem. Chem. Phys. 2010, 12, 12899-12908.

142. Waszkowycz, B.; Clark, D. E.; Gancia, E., Outstanding challenges in protein-ligand docking and structure-based virtual screening. Wiley Interdisciplinary Reviews: Computational Molecular Science 2011, 1, 229-259.

143. Krogsgaard-Larsen, P.; Liljefors, T.; Madsen, U., Textbook of drug design and discovery. Taylor \& Francis: London, 2002.

144. Ferguson, L. N., The Synthesis of Aromatic Aldehydes. Chem. Rev. 1946, 38, 227-254.

145. Reimer, K.; Tiemann, F., Ueber die Einwirkung von Chloroform auf alkalische Phenolate. Ber. Dtsch. Chem. Ges. 1876, 9, 824-828.

146. Reimer, K.; Tiemann, F., Ueber die Einwirkung von Chloroform auf Phenole und besonders aromatische Oxysäuren in alkalischer Lösung. Ber. Dtsch. Chem. Ges. 1876, 9, 1268-1278.

147. Reimer, K.; Tiemann, F., Ueber die Einwirkung von Tetrachlorkohlenstoff auf Phenol in alkalischer Lösung (Bildung von Salicylsäure und Paroxybenzoesäure). Ber. Dtsch. Chem. Ges. 1876, 9, 1285-1287.

148. Gattermann, L., Untersuchungen über Diazoverbindungen. Ber. Dtsch. Chem. Ges. 1890, 23, 
1218-1228.

149. Lederer, L., Eine neue Synthese von Phenolalkoholen. J. Prakt. Chem. 1894, 50, 223-226.

150. Manasse, O., Ueber eine Synthese aromatischer Oxyalkohole. Ber. Dtsch. Chem. Ges. 1894, 27, 2409-2413.

151. Gattermann, L.; Berchelmann, W., Synthese aromatischer Oxyaldehyde. Ber. Dtsch. Chem. Ges. 1898, 31, 1765-1769.

152. Adams, R.; Levine, I., SIMPLIFICATION OF THE GATTERMANN SYNTHESIS OF HYDROXY ALDEHYDES. J. Am. Chem. Soc. 1923, 45, 2373-2377.

153. Vilsmeier, A.; Haack, A., Über die Einwirkung von Halogenphosphor auf Alkyl-formanilide. Eine neue Methode zur Darstellung sekundärer und tertiärer p-Alkylamino-benzaldehyde. Ber. Dtsch. Chem. Ges. 1927, 60, 119-122.

154. Duff, J. C.; Bills, E. J., 273. Reactions between hexamethylenetetramine and phenolic compounds. Part I. A new method for the preparation of 3- and 5-aldehydosalicylic acids. $J$. Chem. Soc. 1932, 1987-1988.

155. Duff, J. C.; Bills, E. J., 282. Reactions between hexamethylenetetramine and phenolic compounds. Part II. Formation of phenolic aldehydes. Distinctive behaviour of pnitrophenol. J. Chem. Soc. 1934, 1305-1308.

156. Laird, T., Aromatic Aldehydes. In Comprehensive Organic Chemistry, Stoddart, J. F., Ed. Pergamon Press: Oxford, New York, 1979; pp 1105-1160.

157. Olah, G. A.; Ohannesian, L.; Arvanaghi, M., Formylating agents. Chem. Rev. 1987, 87, 671686.

158. Meth-Cohn, O.; Stanforth, S. P., The Vilsmeier-Haack Reaction. In Comprehensive Organic Synthesis, Trost, B. M.; Flemming, I., Eds. Pergamon: Oxford, UK, 1991; Vol. 2, pp $777-$ 794.

159. Wynberg, H., The Reimer-Tiemann Reaction In Comprehensive Organic Synthesis, Trost, B. M.; Flemming, I., Eds. Pergamon: Oxford, 1991; Vol. 2, pp 769-775.

160. Gattermann, L.; Koch, J. A., Eine Synthese aromatischer Aldehyde. Ber. Dtsch. Chem. Ges. 1897, 30, 1622-1624.

161. Weisse, L.; Neunteufel, R.; Strutz, H. Selective preparation of hydroxybenzaldehydes. EP0599148, 1994.

162. Willemse, J. A.; Bezuidenhoudt, B. C. B.; Holzapfel, C. W., The HF/BF 3 -catalyzed reaction of substituted benzenes with carbon monoxide. Synthesis 2006, 2543-2550.

163. Vibhute, Y. B.; Lonkar, S. M.; Mokle, S. S.; Sayyed, M. A., An improved procedure for the synthesis of substituted o-hydroxybenzaldehydes by modified operation in the ReimerTiemann reaction. Chem.: Indian J. 2006, 3, 209-211.

164. Matsuda, T.; Murata, T. Process for producing Salicylaldehyde. US 4231967, 1980.

165. L., M. P.; LeRoy, K. Process of preparing hydroxyarylaldehydes. USP 4599457, 1986.

166. Casiraghi, G.; Casnati, G.; Cornia, M.; Pochini, A.; Puglia, G.; Sartori, G.; Ungaro, R., Selective reactions using metal phenoxides. Part 1. Reactions with formaldehyde. J. Chem. Soc. Perk. Trans 1 1978, 318-321.

167. Casiraghi, G.; Casnati, G.; Puglia, G.; Sartori, G.; Terenghi, G., Selective reactions between phenols and formaldehyde. A novel route to salicylaldehydes. J. Chem. Soc. Perk. Trans 1 1980, 1862-1865.

168. Aldred, R.; Johnston, R.; Levin, D.; Neilan, J., Magnesium-mediated ortho-specific formylation and formaldoximation of phenols. J. Chem. Soc. Perk. Trans 1 1994, 18231831 .

169. Wang, R. X.; You, X. Z.; Meng, Q. J.; Mintz, E. A.; Bu, X. R., A Modified Synthesis of OHydroxyaryl Aldehydes. Synth. Commun. 1994, 24, 1757-1760.

170. Hofsløkken, N. U.; Skattebøl, L., Convenient method for the ortho-formylation of phenols. Act. Chem. Scand. 1999, 53, 258-262.

171. Hansen, T. V.; Skattebøl, L., Ortho-formylation of phenols: Preparation of 3- 
bromosalicylaldehyde. Org. Synth. 2005, 82, 64-68.

172. Tishchenko, W., J. Russ. Phys. Chem. Soc. 1906, 20, 355.

173. Oppenauer, R. V., Eine Methode der Dehydrierung von Sekundären Alkoholen zu Ketonen. I. Zur Herstellung von Sterinketonen und Sexualhormonen. Recl. Trac. Chim. Pay. B. 1937, $56,137-144$.

174. Hofsløkken, N. U. Anhydrous Magnesium Dichloride in Organic Synthesis. University of Oslo, 1998.

175. Anwar, H. F.; Skattebøl, L.; Skramstad, J.; Hansen, T. V., One-pot synthesis of orthohydroxycinnamate esters. Tetrahedron Lett. 2005, 46, 5285-5287.

176. Anwar, H. F.; Skattebøl, L.; Hansen, T. V., Synthesis of substituted salicylamines and dihydro-2H-1,3-benzoxazines. Tetrahedron 2007, 63, 9997-10002.

177. Anwar, H. F.; Hansen, T. V., First total synthesis of ( \pm )-powelline. Synlett 2008, 2681-2683.

178. Hansen, T. V.; Skattebøl, L., A high yielding one-pot method for the preparation of salen ligands. Tetrahedron Lett. 2005, 46, 3829-3830.

179. Hansen, T. V.; Wu, P.; Fokin, V. V., One-pot copper(I)-catalyzed synthesis of 3,5disubstituted isoxazoles. J. Org. Chem. 2005, 70, 7761-7764.

180. Wright, B. J. D.; Hartung, J.; Peng, F.; Van de Water, R.; Liu, H.; Tan, Q.-H.; Chou, T.-C.; Danishefsky, S. J., Synthesis of Pluraflavin A "Aglycone". J. Am. Chem. Soc. 2008, 130, 16786-16790.

181. Byun, J. H.; Kim, H.; Kim, Y.; Mook-Jung, I.; Kim, D. J.; Lee, W. K.; Yoo, K. H., Aminostyrylbenzofuran derivatives as potent inhibitors for $\mathrm{A} \beta$ fibril formation. Bioorg. Med. Chem. Lett. 2008, 18, 5591-5593.

182. Chen, Y.; Steinmetz, M. G., Photochemical Cyclization with Release of Carboxylic Acids and Phenol from Pyrrolidino-Substituted 1,4-Benzoquinones Using Visible Light. Org. Lett. 2005, 7, 3729-3732.

183. Nichols, D. E.; Frescas, S. P.; Chemel, B. R.; Rehder, K. S.; Zhong, D.; Lewin, A. H., High specific activity tritium-labeled N-(2-methoxybenzyl)-2,5-dimethoxy-4-iodophenethylamine (INBMeO): A high-affinity 5-HT2A receptor-selective agonist radioligand. Bioorg. Med. Chem. 2008, 16, 6116-6123.

184. Ueno, T.; Koshiyama, T.; Ohashi, M.; Kondo, K.; Kono, M.; Suzuki, A.; Yamane, T.; Watanabe, Y., Coordinated Design of Cofactor and Active Site Structures in Development of New Protein Catalysts. J. Am. Chem. Soc. 2005, 127, 6556-6562.

185. Wittig, G., 1. Synthesen mit lithiumorganischen Verbindungen. Angew. Chem. 1940, 53, 241247.

186. Narasimhan, N. S.; Mali, R. S.; Barve, M. V., Synthetic Application of Lithiation Reactions; Part XIII. Synthesis of 3-Phenylcoumarins and Their Benzo Derivatives. Synth. Commun. 1979, 906-909.

187. Lindsay Smith, J. R.; O'Brien, P.; Reginato, G., Two step synthesis of $C_{2}$ symmetric 2,6diaryl-alkyloxybenzaldehydes-a Mitsunobu approach. Tetrahedron: Asym. 1997, 8, 34153420 .

188. Zacharie, B.; Attardo, G.; Barriault, N.; Penney, C., Regioselective synthesis of 6-substituted 2-hydroxybenzaldehyde: efficient synthesis of the immunomodulator tucaresol and related analogues. J. Chem. Soc. Perk. Trans 1 1997, 2925-2929.

189. Gissot, A.; Becht, J.-M.; Desmurs, J. R.; Pévère, V.; Wagner, A.; Mioskowski, C., Directed ortho-Metalation, a New Insight into Organosodium Chemistry. Angew. Chem. Int. Ed. 2002, 41, 340-343.

190. Gross, H.; Rieche, A.; Matthey, G., Über $\alpha$-Halogenäther, XIII. Neue Verfahren zur Darstellung von Phenolaldehyden. Chem. Ber. 1963, 96, 308-313.

191. Sommers, A. H.; Michaels, R. J.; Weston, A. W., Formylation of the Dimethoxygenzenes Using Phosphorus Oxychloride and N-Methylformanilide. J. Am. Chem. Soc. 1952, 74, 5546-5546. 
192. Lambooy, J. P., The Synthesis of the 2,4-Dihydroxymethylphenylalanines and the Possible Sites of the Linkages between Tyrosinase and Substrate1. J. Am. Chem. Soc. 1956, 78, 771774.

193. Mendelson, W. L.; Hayden, S., Preparation of 2,4-Dihydroxybenzaldehyde by the VilsmeierHaack Reaction. Synth. Commun. 1996, 26, 603-610.

194. Downie, I. M.; Earle, M. J.; Heaney, H.; Shuhaibar, K. F., Vilsmeier formylation and glyoxylation reactions of nucleophilic aromatic compounds using pyrophosphoryl chloride. Tetrahedron 1993, 49, 4015-4034.

195. Bagno, A.; Kantlehner, W.; Scherr, O.; Vetter, J.; Ziegler, G., New Formylating Agents Preparative Procedures and Mechanistic Investigations. Eur. J. Org. Chem. 2001, 29472954.

196. Pattekhan, H. H.; Divakar, S., Regioselectivity in the preparation of 2-hydroxy-4-methoxy benzaldehyde from resorcinol. J. Mol. Catal. A: Chem. 2001, 169, 185-191.

197. Spyriounis, D. M.; Rekka, E.; Demopoulos, V. J.; Kourounakis, P. N., Cu(II) complex of an estradiol derivative with potent anti-inflammatory properties. Arch. Pharm. 1991, 324, 533536.

198. Organon Formyl steroids from the estrane series. NL 6506542, 1966.

199. Rugang, X.; Tu, Y.; Liu, H.; Xu, J.; Zhao, H., Synthesis of 2-formylestrogens and study on their carbon-13 NMR and MS. Acta Chim. Sinica 1988, 46, 14-20.

200. Cushman, M.; He, H.-M.; Katzenellenbogen, J. A.; Lin, C. M.; Hamel, E., Synthesis, Antitubulin and Antimitotic Activity, and Cytotoxicity of Analogs of 2-Methoxyestradiol, an Endogenous Mammalian Metabolite of Estradiol That Inhibits Tubulin Polymerization by Binding to the Colchicine Binding Site. J. Med. Chem. 1995, 38, 2041-2049.

201. El-Tombary, A. A.; Ismail, K. A.; Aboulwafa, O. M.; Omar, A. M. M. E.; El-Reyini, S. H., Synthesis of novel estradiol thiosemicarbazone derivatives as potential antiestrogens. Alexandria J. Pharm. Sci. 1995, 9, 147-152.

202. Brueggemeier, R. W.; Bhat, A. S.; Lovely, C. J.; Coughenour, H. D.; Joomprabutra, S.; Weitzel, D. H.; Vandre, D. D.; Yusuf, F.; Burak, W. E., 2-Methoxymethylestradiol: a new 2methoxy estrogen analog that exhibits antiproliferative activity and alters tubulin dynamics. J. Steroid Biochem. 2001, 78, 145-156.

203. Meltola, N.; Jauria, P.; Saviranta, P.; Mikola, H., Synthesis of Novel Europium-Labeled Estradiol Derivatives for Time-Resolved Fluoroimmunoassays. Bioconjugate Chem. 1999, 10, 325-331.

204. Peters, R. H.; Chao, W.-R.; Sato, B.; Shigeno, K.; Zaveri, N. T.; Tanabe, M., Steroidal oxathiazine inhibitors of estrone sulfatase. Steroids 2003, 68, 97-110.

205. de Ruggieri, P.; Gandolfi, C.; Guzzi, U., aromatization reactions of some 19-nor-androstane derivatives. Tetrahedron Lett. 1966, 7, 205-210.

206. de Ruggieri, P.; Gandolfi, C.; Guzzi, U. 2-CARBONYL-ESTRAREIENES AND METHOD OF THEIR PREPARATION. USP 3562260, 1971.

207. Kumar, V.; Ackerman, J. H.; Alexander, M. D.; Bell, M. R.; Christiansen, R. G.; Dung, J. S.; Jaeger, E. P.; Herrmann, J. L.; Krolski, M. E., Androgen Receptor Affinity of 5'-Acyl Furanosteroids. J. Med. Chem. 1994, 37, 4227-4236.

208. Liu, Y.; Lien, I. F. F.; Ruttgaizer, S.; Dove, P.; Taylor, S. D., Synthesis and Protection of Aryl Sulfates Using the 2,2,2-Trichloroethyl Moiety. Org. Lett. 2004, 6, 209-212.

209. Liu, Y.; Kim, B.; Taylor, S. D., Synthesis of 4-Formyl Estrone Using a Positional Protecting Group and Its Conversion to Other C-4-Substituted Estrogens. J. Org. Chem. 2007, 72, 8824-8830.

210. Rugang, X.; Qiuyun, C.; Jin, X.; Huaming, Z., A new efficient synthetic method for 2- and 4-hydroxy-17 $\alpha$-ethynyIestradiol. Steroids 1990, 55, 488-490.

211. Tornøe, C. W.; Sanderson, S. J.; Mottram, J. C.; Coombs, G. H.; Meldal, M., Combinatorial Library of Peptidotriazoles: Identification of [1,2,3]-Triazole Inhibitors against a 
Recombinant Leishmania mexicana Cysteine Protease. J. Comb. Chem. 2004, 6, 312-324.

212. Whiting, M.; Muldoon, J.; Lin, Y.-C.; Silverman, S. M.; Lindstrom, W.; Olson, A. J.; Kolb, H. C.; Finn, M. G.; Sharpless, K. B.; Elder, J. H.; Fokin, V. V., Inhibitors of HIV-1 Protease by Using In Situ Click Chemistry. Angew. Chem. Int. Ed. 2006, 45, 1435-1439.

213. Krivopalov, V. P.; Shkurko, O. P., 1,2,3-Triazole and its derivatives. Development of methods for the formation of the triazole ring. Russ. Chem. Rev. 2005, 74, 339-379.

214. Husigen, R., 1,3-Dipolar Cycloaddition Chemistry. Padwa, A., Ed. John Wiley \& Sons: New York, 1984; pp 1-176.

215. Cantillo, D.; Avalos, M.; Babiano, R.; Cintas, P.; Jimenez, J. L.; Palacios, J. C., Assessing the whole range of CuAAC mechanisms by DFT calculations-on the intermediacy of copper acetylides. Org. Biomol. Chem. 2011, 9, 2952-2958.

216. Himo, F.; Lovell, T.; Hilgraf, R.; Rostovtsev, V. V.; Noodleman, L.; Sharpless, K. B.; Fokin, V. V., Copper(I)-Catalyzed Synthesis of Azoles. DFT Study Predicts Unprecedented Reactivity and Intermediates. J. Am. Chem. Soc. 2005, 127, 210-216.

217. Tornøe, C. W.; Christensen, C.; Meldal, M., Peptidotriazoles on Solid Phase: [1,2,3]Triazoles by Regiospecific Copper(I)-Catalyzed 1,3-Dipolar Cycloadditions of Terminal Alkynes to Azides. J. Org. Chem. 2002, 67, 3057-3064.

218. Rostovtsev, V. V.; Green, L. G.; Fokin, V. V.; Sharpless, K. B., A Stepwise Huisgen Cycloaddition Process: Copper(I)-Catalyzed Regioselective "Ligation" of Azides and Terminal Alkynes. Angew. Chem. Int. Ed. 2002, 41, 2596-2599.

219. Spiteri, C.; Moses, J. E., Copper-Catalyzed Azide-Alkyne Cycloaddition: Regioselective Synthesis of 1,4,5-Trisubstituted 1,2,3-Triazoles. Angew. Chem. Int. Ed. 2010, 49, 31-33.

220. Rodionov, V. O.; Fokin, V. V.; Finn, M. G., Mechanism of the Ligand-Free CuI-Catalyzed Azide-Alkyne Cycloaddition Reaction. Angew. Chem. Int. Ed. 2005, 44, 2210-2215.

221. Zhang, L.; Chen, X.; Xue, P.; Sun, H. H. Y.; Williams, I. D.; Sharpless, K. B.; Fokin, V. V.; Jia, G., Ruthenium-Catalyzed Cycloaddition of Alkynes and Organic Azides. J. Am. Chem. Soc. 2005, 127, 15998-15999.

222. Majireck, M. M.; Weinreb, S. M., A Study of the Scope and Regioselectivity of the Ruthenium-Catalyzed [3 +2$]$-Cycloaddition of Azides with Internal Alkynes. J. Org. Chem. 2006, 71, 8680-8683.

223. Rasmussen, L. K.; Boren, B. C.; Fokin, V. V., Ruthenium-Catalyzed Cycloaddition of Aryl Azides and Alkynes. Org. Lett. 2007, 9, 5337-5339.

224. Boren, B. C.; Narayan, S.; Rasmussen, L. K.; Zhang, L.; Zhao, H.; Lin, Z.; Jia, G.; Fokin, V. V., Ruthenium-Catalyzed Azide-Alkyne Cycloaddition: Scope and Mechanism. J. Am. Chem. Soc. 2008, 130, 8923-8930.

225. Kwok, S. W.; Fotsing, J. R.; Fraser, R. J.; Rodionov, V. O.; Fokin, V. V., Transition-MetalFree Catalytic Synthesis of 1,5-Diaryl-1,2,3-triazoles. Org. Lett. 2010, 12, 4217-4219.

226. Akimova, G. S.; Chistokletov, V. N.; Petrov, A. A., 1,3-Dipolar addition to unsaturated compounds. XVII. Reactions of azides with organomagnesium bromide complexes prepared from phenyl- and alkenylacetylenes. Zh. Org. Kh. 1967, 3, 968-974.

227. Akimova, G. S.; Chistokletov, V. N.; Petrov, A. A., 1,3-Dipolar addition to unsaturated compounds. XVIII. Reactions of aliphatic and aromatic azides with Iotsich [Grignard] complexes prepared from acetylene, diacetylene, and their homologs. Zh. Org. Kh. 1967, 3, 2241-2247.

228. Krasiński, A.; Fokin, V. V.; Sharpless, K. B., Direct Synthesis of 1,5-Disubstituted-4magnesio-1,2,3-triazoles, Revisited. Org. Lett. 2004, 6, 1237-1240.

229. Odlo, K.; Hentzen, J.; dit Chabert, J. F.; Ducki, S.; Gani, O. A. B. S. M.; Sylte, I.; Skrede, M.; Flørenes, V. A.; Hansen, T. V., 1,5-Disubstituted 1,2,3-triazoles as cis-restricted analogues of combretastatin A-4: Synthesis, molecular modeling and evaluation as cytotoxic agents and inhibitors of tubulin. Bioorg. Med. Chem. 2008, 16, 4829-4838.

230. Rimul, G. F. Celledød, aktivering av caspase 3, og NGFIB-forflytning icellelinjene PC12 og 
CV1. University of Oslo, Oslo, 2007.

231. Moe, L. K. Procaspase activating compound-1 (PAC-1): effekter på celledød og caspaseaktivitet i cellelinjen PC12 og kyllingkornceller. Master, University of Oslo, Oslo, 2010.

232. Kamat, V. S.; Chuo, F. Y.; Kubo, I.; Nakanishi, K., Antimicrobial agents from an East African medicinal plant Erythrina abyssinica. Heterocycles 1981, 15, 1163-1170.

233. Kozubek, A.; Tyman, J. H. P., Resorcinolic Lipids, the Natural Non-isoprenoid Phenolic Amphiphiles and Their Biological Activity. Chem. Rev. 1999, 99, 1-26.

234. Pandey, J.; Jha, A. K.; Hajela, K., Synthesis and biological activities of some new dibenzopyranones and dibenzopyrans: search for potential oestrogen receptor agonists and antagonists. Bioorg. Med. Chem. 2004, 12, 2239-2249.

235. Shi, Y.-L.; Shi, M., The synthesis of chromenes, chromanes, coumarins and related heterocycles via tandem reactions of salicylic aldehydes or salicylic imines with $\alpha, \beta-$ unsaturated compounds. Org. Biomol. Chem. 2007, 5, 1499-1504.

236. Winssinger, N.; Barluenga, S., Chemistry and biology of resorcylic acid lactones. Chem. Commun. 2007, 22-36.

237. Anwar, H. F.; Hansen, T. V., First Total Synthesis of a Polyunsaturated Chromone Metabolite Isolated from the Brown Algae Zonaria tournefortii. Org. Lett. 2009, 11, 587588.

238. Shinonaga, H.; Kawamura, Y.; Ikeda, A.; Aoki, M.; Sakai, N.; Fujimoto, N.; Kawashima, A., Pochonins K-P: New radicicol analogs from Pochonia chlamydosporia var. chlamydosporia and their WNT-5A expression inhibitory activities. Tetrahedron 2009, 65, 3446-3453.

239. Goodenough, R. D.; Stenger, V. A., Comprehensive inorganic chemistry. Bailar, J. C.; Trotman-Dickenson, A. F., Eds. Pergamon Press: Oxford, 1973; Vol. I, pp 629-636.

240. Aylett, B. J., Comprehensive inorganic chemistry. Bailar, J. C.; Trotman-Dickenson, A. F., Eds. Pergamon Press: Oxford, 1973; Vol. III, pp 208-217.

241. Frandsen, V. A., Demonstration of 2-methoxyestrone and of 2-methoxyestradiol in human pregnancy urine. Acta Endocrinol. 1959, 31, 603-607.

242. Sajan, D.; Abraham, J. P.; Hubert Joe, I.; Jayakumar, V. S.; Aubard, J.; Faurskov Nielsen, O., Molecular structure, vibrational spectra and first-order molecular hyperpolarizabilities of potential anti-cancer drug, combretastatin-A1. J. Mol. Struct. 2008, 889, 129-143.

243. Odlo, K.; Fournier-Dit-Chabert, J.; Ducki, S.; Gani, O. A. B. S. M.; Sylte, I.; Hansen, T. V., 1,2,3-Triazole analogs of combretastatin A-4 as potential microtubule-binding agents. Bioorg. Med. Chem. 2010, 18, 6874-6885.

244. Cafici, L.; Pirali, T.; Condorelli, F.; Del Grosso, E.; Massarotti, A.; Sorba, G.; Canonico, P. L.; Tron, G. C.; Genazzani, A. A., Solution-Phase Parallel Synthesis and Biological Evaluation of Combretatriazoles. J. Comb. Chem. 2008, 10, 732-740.

245. Romagnoli, R.; Baraldi, P. G.; Cruz-Lopez, O.; Lopez Cara, C.; Carrion, M. D.; Brancale, A.; Hamel, E.; Chen, L.; Bortolozzi, R.; Basso, G.; Viola, G., Synthesis and Antitumor Activity of 1,5-Disubstituted 1,2,4-Triazoles as Cis-Restricted Combretastatin Analogues. J. Med. Chem. 2010, 53, 4248-4258.

246. Zhang, Q.; Peng, Y.; Wang, X. I.; Keenan, S. M.; Arora, S.; Welsh, W. J., Highly Potent Triazole-Based Tubulin Polymerization Inhibitors. J. Med. Chem. 2007, 50, 749-754.

247. Tao, C.-Z.; Cui, X.; Li, J.; Liu, A.-X.; Liu, L.; Guo, Q.-X., Copper-catalyzed synthesis of aryl azides and 1-aryl-1,2,3-triazoles from boronic acids. Tetrahedron Lett. 2007, 48, 35253529.

248. Colvin, E. W.; Hamill, B. J., One- step Conversion of Carbonyl Compounds into Acetylenes. J. Chem. Soc. Chem. Comm. 1973, 2, 151-152.

249. Corey, E. J.; Fuchs, P. L., A synthetic method for formyl $\rightarrow$ ethynyl conversion $(\mathrm{RCHO} \rightarrow \mathrm{RCCH}$ or RCCR'). Tetrahedron Lett. 1972, 13, 3769-3772.

250. Ohira, S., Methanolysis of Dimethyl (1-Diazo-2-oxopropyl) Phosphonate: Generation of 
Dimethyl (Diazomethyl) Phosphonate and Reaction with Carbonyl Compounds. Synth. Commun. 1989, 19, 561-564.

251. Roth, G. J.; Liepold, B.; Müller, S. G.; Bestmann, H. J., Further Improvements of the Synthesis of Alkynes from Aldehydes. Synthesis 2004, 59-62.

252. Müller, S.; Liepold, B.; Roth, G. J.; Bestmann, H. J., An Improved One-pot Procedure for the Synthesis of Alkynes from Aldehydes. Synlett 1996, 521-522.

253. Sun, C.-M.; Lin, L.-G.; Yu, H.-J.; Cheng, C.-Y.; Tsai, Y.-C.; Chu, C.-W.; Din, Y.-H.; Chau, Y.-P.; Don, M.-J., Synthesis and cytotoxic activities of 4,5-diarylisoxazoles. Bioorg. Med. Chem. Lett. 2007, 17, 1078-1081.

254. Nam, N.-H.; Kim, Y.; You, Y.-J.; Hong, D.-H.; Kim, H.-M.; Ahn, B.-Z., Combretoxazolones: synthesis, cytotoxicity and antitumor activity. Bioorg. Med. Chem. Lett. 2001, 11, 30733076.

255. Yoo, S.-e.; Lee, S.-h., Reduction of Organic Compounds with Sodium BorohydrideCopper(II) Sulfate System. Synlett 1990, 419-420.

256. Baeyer, A.; Villiger, V., Einwirkung des Caro'schen Reagens auf Ketone. Ber. Dtsch. Chem. Ges. 1899, 33, 3625-3633.

257. Baeyer, A.; Villiger, V., Ueber die Einwirkung des Caro'schen Reagens auf Ketone. Ber. Dtsch. Chem. Ges. 1900, 33, 858-864.

258. Jones, G. H.; Venuti, M. C.; Young, J. M. Naphthalene anti-psoriatic agents. 4840965, 1989.

259. Hahn, E.; Rupprecht, S.; Kramp, W.; Neumeier, R. Reducing chelating agents, their technetium and rhenium complexes, process for their production as well as their use in diagnosis and treatment. CA2048899 (A1), 1992.

260. Yardley, J. P.; Fletcher 3rd, H., Introduction of the Methoxymethyl Ether Protecting Group. Synthesis 1976, 244.

261. Stork, G.; Takahashi, T., Chiral synthesis of prostaglandins (PGE1) from D-glyceraldehyde. J. Am. Chem. Soc. 1977, 99, 1275-1276.

262. Morris, G. M.; Goodsell, D. S.; Halliday, R. S.; Huey, R.; Hart, W. E.; Belew, R. K.; Olson, A. J., Automated docking using a Lamarckian genetic algorithm and an empirical binding free energy function. J. Comput. Chem. 1998, 19, 1639-1662.

263. Friesner, R. A.; Banks, J. L.; Murphy, R. B.; Halgren, T. A.; Klicic, J. J.; Mainz, D. T.; Repasky, M. P.; Knoll, E. H.; Shelley, M.; Perry, J. K.; Shaw, D. E.; Francis, P.; Shenkin, P. S., Glide: A New Approach for Rapid, Accurate Docking and Scoring. 1. Method and Assessment of Docking Accuracy. J. Med. Chem. 2004, 47, 1739-1749.

264. Halgren, T. A.; Murphy, R. B.; Friesner, R. A.; Beard, H. S.; Frye, L. L.; Pollard, W. T.; Banks, J. L., Glide: A New Approach for Rapid, Accurate Docking and Scoring. 2. Enrichment Factors in Database Screening. J. Med. Chem. 2004, 47, 1750-1759.

265. Jones, G.; Willett, P.; Glen, R. C., Molecular recognition of receptor sites using a genetic algorithm with a description of desolvation. J. Mol. Bio. 1995, 245, 43-53.

266. McGann, M. R.; Almond, H. R.; Nicholls, A.; Grant, J. A.; Brown, F. K., Gaussian docking functions. Biopolymers 2003, 68, 76-90.

267. O'Boyle, N. M.; Liebeschuetz, J. W.; Cole, J. C., Testing Assumptions and Hypotheses for Rescoring Success in Protein-Ligand Docking. J. Chem. Inf. Model. 2009, 49, 1871-1878.

268. Czakó, B.; Kürti, L.; Mammoto, A.; Ingber, D. E.; Corey, E. J., Discovery of Potent and Practical Antiangiogenic Agents Inspired by Cortistatin A. J. Am. Chem. Soc. 2009, 131, 9014-9019.

269. Yamaguchi, M.; Arisawa, M.; Omata, K.; Kabuto, K.; Hirama, M.; Uchimaru, T., OrthoVinylation Reaction of Phenols with Ethyne. J. Org. Chem. 1998, 63, 7298-7305.

270. Sánchez-Obregón, R.; Hurtado, G.; Barrios, H.; Ortíz, B.; Yuste, F., A FACILE SYNTHESIS OF 3-BENZYLOXY-5-METHOXYPHENOL. Org. Prep. Proced. Int. 1986, 18, 145-148.

271. Rao, P. N.; Cessac, J. W.; Boyd, J. W.; Hanson, A. D.; Shah, J., Synthesis and antimitotic activity of novel 2-methoxyestradiol analogs. Part III. Steroids 2008, 73, 171-183. 
272. Crawford, M.; Rasburn, J. W., The stability of coumarinic acids. Chelation of the hydroxyl group. J. Chem. Soc. 1956, 2155-2160.

273. Ruggli, P.; Burckhardt, E., Nitration of 2-hydroxy-1-naphthaldehyde. Helv. Chim. Acta 1940, 23, 445-449.

274. Loevgren, K.; Hedberg, A.; Nilsson, J. L. G., Adrenergic receptor agonists. J. Med. Chem. 1980, 23, 624-627.

275. Kauch, M.; Hoppe, D., Synthesis of Halogenated Phenols by Directed ortho-Lithiation and ipso-Iododesilylation Reactions of O-Aryl N-Isopropylcarbamates. Synthesis 2006, 15781589 . 


\section{List of papers}

I) ortho-Formylation of oxygenated phenols.

Akselsen, Ø. W.; Skattebøl, L.; Hansen, T. V. Tetrahedron Lett. 2009, 50, 6339-6341.

II) Procaspase-activating compound 1 induces a caspase-3-dependent cell death in cerebellar granule neurons.

Aziz, G.; Akselsen, Ø. W.; Hansen, T. V.; Paulsen, R. E. Toxicol. Appl. Pharmacol. 2010, 247, 238-242.

III) ortho-Formylation of estrogens. Synthesis of the anti-cancer agent 2-methoxyestradiol.

Akselsen, Ø. W.; Hansen, T. V. Tetrahedron 2011, 67, 7738-7742.

IV) Synthesis, biological evaluation and molecular modeling of 1,2,3-triazole analogs of combretastatin A-1.

Akselsen, Ø. W.; Odlo, K.; Cheng, J-J.; Maccari, G.; Botta, M.; Hansen. T. V. Bioorg. Med. Chem. 2011. Accepted. 



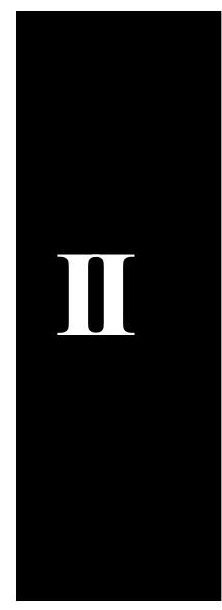





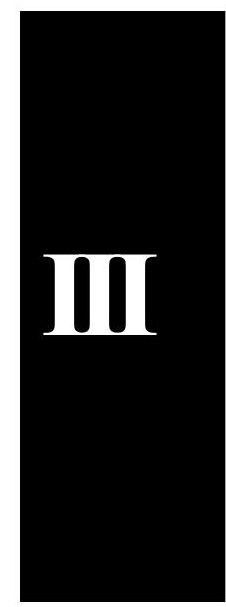





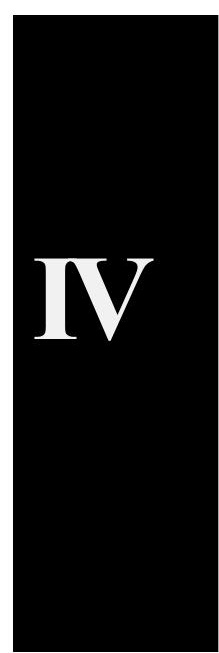


